\title{
Compreendendo o Conceito de Fadiga: Estudo de Caso dos Trabalhadores em uma Indústria Gráfica
}

MARIA DE FÁTIMA FERREIRA QUEIRÓZ

Tese apresentada na área de concentração de Saúde Ambiental da Faculdade de Saúde Pública da Universidade de São Paulo para obtenção do grau de Doutora

Área de Concentração:

Saúde Ambiental-Saúde do Trabalhador

ORIENTADORA:

PROFa DR ${ }^{a}$ REGINA HELOÍSA MACIEL 
Para Mário, meu querido companheiro, desde 1981, a quem amo muito e quem com sua compreensiva visão do mundo, e do ser humano, me tornou calma e feliz em todos estes anos. Sem o entendimento e o conhecimento que você tem da área da saúde, principalmente da Medicina Tradicional Chinesa, e da importância dos estudos nesta área, penso que minha jornada teria sido mais difícil. Obrigado por me ajudar a ser o que sou hoje.

Para meus queridos e lindos filhos: Aina e latã. Vocês são o maior presente que este mundo me concedeu. É muito gostoso conviver com vocês, poder ser mãe, e acredito que vocês serão individuos íntegros, amorosos e felizes. E lembro a vocês que o tão esperado dia de terminar esta tese chegou e agora poderemos estar mais juntos.

Para minha querida mãe Áurea e meu querido pai Geraldo (in memoriam) que proveram a base para meu desenvolvimento e me ensinaram o quão importante é o carinho, a sinceridade, a honestidade, a dedicação e o amor. 


\section{AGRADECIMENTOS}

Agradeço a querida amiga e orientadora Regina Maciel. A admiração que tenho por seu conhecimento na área de pesquisa e por seu entendimento do ser humano não tem palavras que possam expressar. Só sei dizer que tenho o privilégio de conhecer o papel de um orientador, que ensina, está sempre próximo e trata seu orientando com carinho e compreensão visando formar um pesquisador. Obrigado por estes 8 anos de convivência, cheio de bons momentos e afetividade e que nossa amizade se prolongue por todo 0 tempo de nossa vida neste planeta.

Agradeço em especial aos trabalhadores que me permitiram um convivio com momentos muito bons durante a fase da coleta de dados. Esta pesquisa só existe porque vocês deixaram seus discursos fluírem e foi possivel que eu os conhecesse. Desejo que vocês encontrem o caminho que for melhor para suas vidas e sejam felizes nele.

A Adriana Siqueira e Maria Lúcia Udihara, minhas grandes amigas, que estão sempre dispostas a me compreender diante dos meus anseios e muito me incentivaram sempre lembrando da minha persistência para concluir esta pesquisa.

Agradeço a Mônica Giannotti e Sissy Veloso, amigas especiais e muito queridas, pelo carinho, incentivo e contribuição no conhecimento sobre Neurociências.

A querida amiga Fátima Marinho, ótima epidemiologista, pelo incentivo para estudar sobre a fadiga desde o início desta pesquisa e pela ajuda na análise dos dados quantitativos.

A amiga Jenny Kose pelo apoio recebido principalmente na fase de redação desta tese. Você é uma pessoa especial. Obrigado. 
Ao amigo Marcus Vinicius Gava por me incentivar e apontar os caminhos de crescimento dentro da área da Fisioterapia e Trabalho.

A empresa que facilitou a realização desta pesquisa em especial a Ana Garbin que reconheceu a necessidade e importância de estudos na área da fadiga e trabalho.

Agradeço as amigas Ângela Silva, Maria Aparecida Mendes, Renilda Shimono e Márcia Garcia, funcionárias da CPG da Faculdade de Saúde Publica da Usp, que sempre estiveram dispostas a oferecer sua ajuda não só a mim, como a qualquer aluno que necessita de informação e orientação. Acredito que vocês fazem o seu trabalho com carinho e amor e ganham amigos durante essa nossa jornada na Faculdade.

Com muito carinho agradeço às (os) funcionárias (os) da Biblioteca Centro de Informação e Referência da Faculdade de Saúde Pública -USP pela atenção para conosco e dedicação no trabalho realizado com muita competência. Em especial agradeço a Maria do Carmo Alvarez pelo carinho com que nos provê das informações solicitadas com uma atitude sempre compreensiva. $O$ trabalho desta equipe da Biblioteca é muito importante para a nossa formação acadêmica.

Agradeço em especial as Professoras Sabina Léa Gotlieb e Ana Cristina Tanaka pela atenção, apoio e interesse por meu trabalho de pesquisa durante minha jornada na Faculdade de Saúde Pública-USP.

Aos amigos que participaram das etapas vividas no processo de construção desta pesquisa, sempre com compreensão e carinho: Berenice Chiarello, Mariana Rangel, Patrícia Salerno, Cristiane Lopes, Mário Cesaretti, Anderson Mota, Wanda Pereira, Reis Oliveira, Leila Machado, lara Silveira, Rita Bessa, Carlos Ferreira, Elzira Mitiko, Maristela Maule, Kátia Silva, Márcio Rolim, Marize Duarte, Yara Prado, Hélio Neves, Luciane Frizo, Flora Vezzá, Ângela Maciel e Wanderlei Anibali. 


\section{RESUMO}

Queiroz MFF. Compreendendo o Conceito de Fadiga: Estudo de Caso dos Trabalhadores em uma Indústria Gráfica. São Paulo; 2003. [Tese de Doutorado - Faculdade de Saúde Pública da Universidade de São Paulo].

Considerando que os estudiosos de diversas áreas do conhecimento apresentam a fadiga como um fenômeno complexo e de difícil definição, realizou-se um estudo visando analisar a presença do estado de sensação de fadiga em um grupo de trabalhadores de uma indústria gráfica da região metropolitana de São Paulo. Utilizou-se três abordagens nesta pesquisa: uma quantitativa e duas qualitativas. $O$ grupo foi composto por 200 trabalhadores. $\mathrm{Na}$ abordagem quantitativa aplicou-se um questionário amplamente usado em estudos sobre fadiga. $\mathrm{Na}$ abordagem qualitativa optou-se pela realização de uma investigação, não exaustiva, sobre o trabalho $e$ as condições de trabalho, utilizando-se a observação livre do posto de trabalho e uma avaliação da fadiga a partir do discurso dos trabalhadores. No total dos trabalhadores analisados; $145(72,5 \%)$ eram homens e $55(27,5 \%)$ mulheres. No grupo, a taxa de prevalência de fadiga profunda foi $37,5 \%$. A prevalência para os homens foi de $35,9 \%$ e para as mulheres foi de $41,8 \%$. A análise da fadiga por estado civil e sexo apresentou um indice de fadiga com freqüência maior para as mulheres casadas $(73,9 \%, 17)$ do que para as solteiras $(26,1 \%, 6)$. Essa diferença é estatisticamente significativa $\left(x^{2}=5,98 ; p=0,01\right)$. A prevalência de fadiga crônica foi de $7,0 \%$, com $5,5 \%$ para os homens e $10,9 \%$ para as mulheres. $\mathrm{Na}$ abordagem qualitativa, entrevistou-se 23 trabalhadores, sendo $8 \mathrm{com}$ fadiga e 15 sem fadiga, segundo a Escala de Fadiga aplicada. No discurso dos trabalhadores com fadiga estes se sentiam cansados (as) mentalmente e fisicamente, expressando-se como sem ânimo, irritados (as), com estresse, além de relatarem dores nos ombros, nas mãos e nas pernas. Segundo eles, ficar cansado é pior que ficar doente. O enfretamento da situação de fadiga passa por estar sempre recuperando as energias, descansando ou estando com a alma (mente) preparada para poder suportar 
aquele instante. A observação do trabalho nos postos dos setores estudados apontou a presença de fatores associados à determinação de fadiga. Por exemplo, uma produção que ocorria em condições de velocidade alta com repetição de movimentos em ciclos curtos de trabalho, exigência de atenção e concentração e um trabalho realizado sob pressão externa e interna. A fadiga mostrou-se como uma condição presente nos indivíduos e de difícil definição, devido, provavelmente, à sua característica complexa. Esta pesquisa apontou uma alta prevalência de fadiga para o conjunto de trabalhadores estudados e uma maior prevalência em mulheres do que em homens, com um maior acometimento em mulheres casadas. $A$ abordagem quantitativa do fenômeno fadiga restringiu-se a sinais e sintomas prédeterminados. $\mathrm{Na}$ abordagem qualitativa a fadiga mostrou ser um fenômeno que depende, em parte, da maneira como o indivíduo cria estratégias de enfrentamento diante da situação de trabalho. O papel da estratégia de enfrentamento parece ser importante e estar associado à determinação da ocorrência da fadiga. Esta pesquisa mostra que um caminho para a compreensão da fadiga é uma concepção mais abrangente do fenômeno. 


\section{ABSTRACT}

Queiroz MFF. Compreendendo o Conceito de Fadiga: Estudo de Caso dos Trabalhadores em uma Indústria Gráfica [Understanding the Concept of Fatigue: Case Studies of Workers in the Graphic Industry]. São Paulo (BR); 2003. [PhD Thesis - Faculdade de Saúde Pública da Universidade de São Paulo].

Considering that several authors of different areas of knowledge view fatigue as a complex phenomenon and the difficulties to define the concept of fatigue, this study analyzes the presence of the sensation of the fatigue state in a group of workers of a graphic industry of the metropolitan area of São Paulo. Three approaches were used in this research: a quantitative one and two qualitative. Participated in the study a group of 200 workers. The quantitative approach consisted in the application of a questionnaire widely used in studies about fatigue. The qualitative approach was accomplished by an investigation, not exhaustive, about the work and the working conditions using free observations of the working stations and an evaluation of the worker's fatigue using the a method of discourse analyses. Of the total of workers, $145(72,5 \%)$ were men and $55(27,5 \%)$ women. The prevalence of profound fatigue in the group was $37,5 \%$. The prevalence in the men's group was $35,9 \%$ and in the women's group was $41,8 \%$. The analysis of fatigue taking into consideration the marital status and sex showed a greater rate of fatigue among married women $(73,9 \%, 17)$ when than for unmarried women $(26,1 \%, 6)$. This difference has significance statistical $\left(x^{2}=5,98 ; p=0,01\right)$. The prevalence of chronic fatigue was $7,0 \%, 5,5 \%$ in the men's group and $10,9 \%$ in the women's group. In the qualitative approach, 23 workers were interviewed, being 8 with fatigue and 15 without according to the Scale of Fatigue applied initially. The discourse of the fatigued workers showed that they felt tired mentally and physically, expressing a lack of enthusiasm, irritation, stress, besides that, they complained of shoulder, hands and legs pains. According to them, being tired is worse than being sick. The coping strategies adopted to deal with the fatigue situation consisted of being always recovering energies, resting or preparing the soul (mind) to stand the situation. The work observations of the stations studied pointed to the presence of factors associated to the determination of fatigue, as, for example, a high rate of production, repetition and short work cycles, a high 
level of attention and concentration and a work accomplished under external and internal pressure. The results showed that fatigue was a condition present in the individuals and of difficult definition, due, probably, to its complexity. This research showed a high prevalence of fatigue among the workers studied and a greater prevalence in women than in men, affecting mainly married women. The quantitative approach of the fatigue phenomenon is restricted to pre-defined signals and symptoms. The qualitative approach showed that the fatigue phenomenon is dependent, in part, of the coping strategies that the individual creates to face his (her) working situation. The role of the coping strategies seems to be important and a factor associated to the determination of the occurrence of fatigue. This research showed that a way for the understanding of the fatigue concept is a broader approach of the phenomenon. 


\section{INDICE}

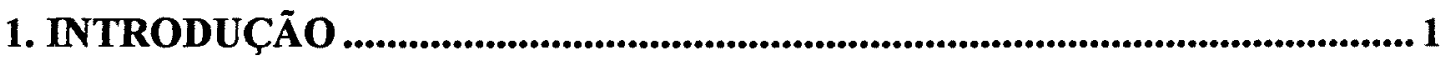

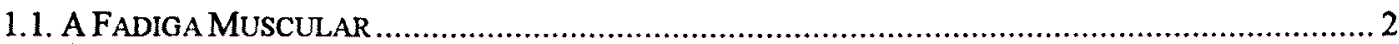

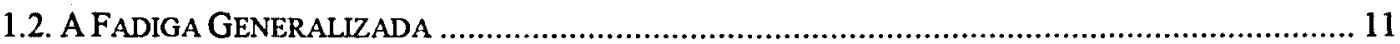

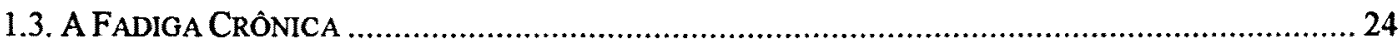

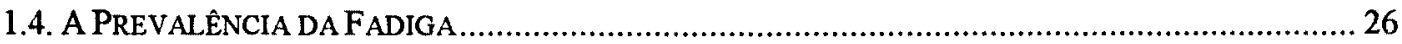

1.5. A MEDIDA DA FADIGA

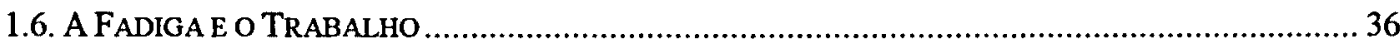

1.6.1. Determinação do Processo Saúde/Doença no Trabalho e a Fadiga............................... 36

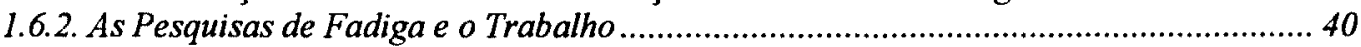

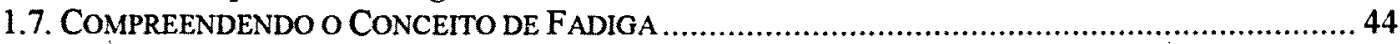

2. OBJETTVOS E HIPÓTESE........................................................................... 50

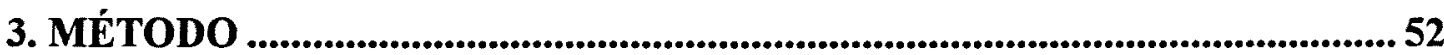

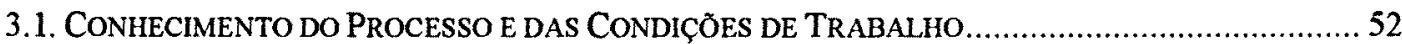

3.2. AVALIAÇÃO DA SENSAÇÃo DE FADIGA ATRAVÉS DE UM QUESTIONÁRIO...............................53

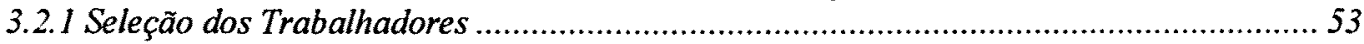

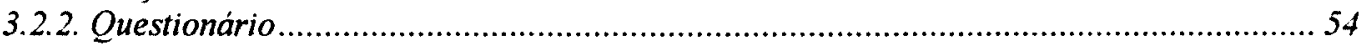

3.3. AVALIAÇÃo da SENSAÇÃo de FAdiga A PARTIR do Discurso dos TRABALHADORES .......... 56

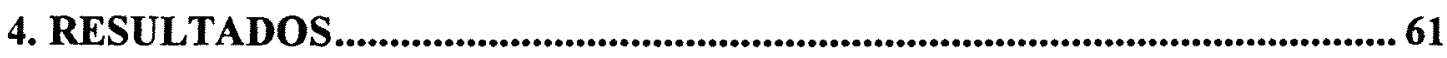

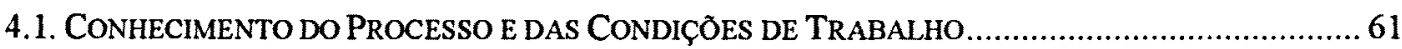

4.1.1. Descrição do Trabalho no Setor de Acabamento (SA) ..................................................... 61

4.1.2. Descrição do Trabalho no Setor Telemarketing Ativo (STA) ....................................... 77

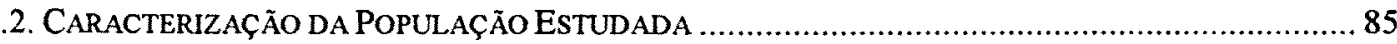

4.2.1. Quantificação da Fadiga nos Trabalhadores Estudados ........................................... 88

4.2.2. Análise dos Motivos da Fadiga ou Cansaço ............................................................. 95

4.3. PERCEPÇÃo do Estado de Fadiga ATRAVÉs de ENTREVISTAS SEMI-EstrutURAdAs: UMA

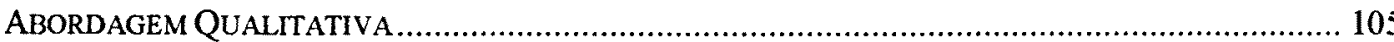

4.3.1. Definição dos Temas para a Descrição do Discurso ................................................. 107

4.3.2. Discurso dos Trabalhadores com Fadiga …….................................................. 110

4.3.3. Discurso dos Trabalhadores sem Fadiga................................................................ 122

4.3.4. Comparação dos Discursos dos Trabalhadores com Fadiga e sem Fadiga................. 136

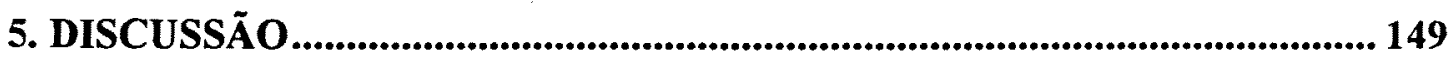

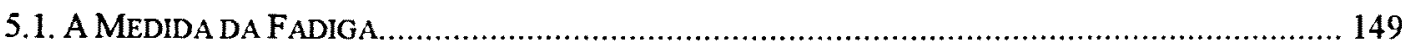

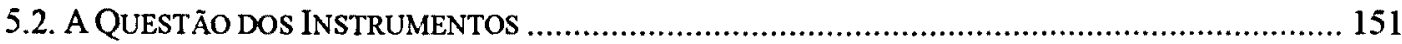

5.3. COMPARAÇÃO ENTRE OS DISCURSOS DOS QUE APRESENTAM E DOS QUE NÃO APRESENTAM

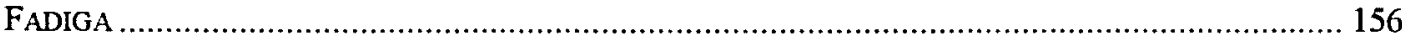

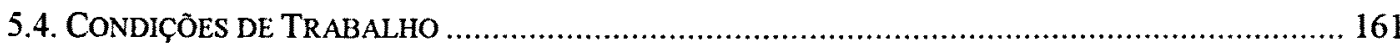

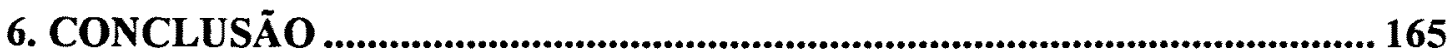

7- REFERÊNCIAS BIBLIOGRÁFICAS ............................................................ 169

Anexo I

Anexo II

Anexo III

Anexo IV

Anexo V 


\section{INTRODUÇÃO}

A fadiga tem sido objeto de estudo em diversas áreas do conhecimento, abrangendo, principalmente, a fisiologia, a psicologia e a medicina. No entanto, os estudiosos não conseguiram fornecer, ainda, um quadro coeso de conceitos e problemas em pesquisas sobre fadiga. A justificativa para tal limitação pode estar na dificuldade de definir o conceito de fadiga com precisão. Como não há uma definição precisa, vários são os parâmetros utilizados para abordar a fadiga. Nos estudos sobre a fadiga cada pesquisador se refere a ela conforme seu entendimento. $O$ conceito de fadiga se confunde com seus sintomas e sinais, outras vezes sintomas e sinais se transformam em componentes da fadiga e esta pode até ser confundida com estresse, dificultando uma definição conceitual plausivel. A grande maioria dos pesquisadores se refere à fadiga como um fenômeno complexo e de difícil definição (Muscio 1921a, 1921 b; Schwab 1953; Welford 1953; Crawford 1961; Grandjean 1968; Tsaneva and Markov 1971; Örtengren et al. 1975; Binashi et al. 1982; Lee 1994; Wessely et al. 1998; Ånsberg 2000).

O termo fadiga surgiu do latim (faticare) e quer dizer "cansaço por motivo de trabalho intenso, pena do corpo ou do espírito, cansaço, canseira, trabalho, lida. Exausto como correndo ou trabalhando, cansado de importunar (Ream 1996, Ferreira 1994-1995, Aulete 1964). O termo fadiga aparece na literatura médica em 1869, quando o médico nova-iorquino George Beard (citado em Wessely et al. 1998 e Loriol 2002) estudou o que denominou de neurastenia - a doença da fadiga. A partir de então os estudos sobre a fadiga se ampliaram. Segundo Wessely et al. (1998), a fadiga é um conceito conveniente, mas problemático, pois todos nós sabemos o que o termo quer dizer na "linguagem coloquial", mas para um propósito mais preciso, de pesquisa, o significado pode ser vago, alusivo e de dificil operacionalização. A dificuldade de definição é tão importante 
quando se estuda a fadiga que Bernard Muscio (1921a), um dos pioneiros da área, propôs que o termo fosse abandonado. Apesar disso, na literatura pesquisada, não observamos nenhuma outra proposta alternativa para 0 conjunto de fenômenos agregados sob a denominação de "fadiga".

Os fisiologistas, em vários experimentos de laboratório, têm tentado localizar a fadiga em alguma parte do corpo (McFarland 1971). Estes estudos se iniciam com o reconhecimento de fadiga em um músculo, ou grupos musculares e se inserem dentro da rúbrica de fadiga muscular.

\subsection{A Fadiga Muscular}

Wessely et al. (1998) fazem uma retrospectiva histórica dos estudos sobre a fadiga muscular começando com os estudos de Mosso, um fisiologista italiano. No seu artigo original, Mosso (1896) relata que a fadiga muscular começa a ser estudada em laboratórios, fazendo uso de animais para os experimentos e afirma que a fadiga é um processo de natureza química. Em 1884, Mosso tinha inventado o "ergograph" e em 1904 publicou seu livro "Fadiga" onde são descritos experimentos usando o equipamento. O "ergograph" mede decréscimos no desempenho decorrentes da repetição de uma simples tarefa. O equipamento desenha uma curva de fadiga, registrando os movimentos de um dedo submetido a repetidos levantamentos de peso. A característica principal desta abordagem é medir a fadiga enquanto um fenômeno muscular. $O$ trabalho de Mosso enfocou somente um dos vários fenômenos da fadiga: a medida do decréscimo no desempenho. Mosso chegou a quatro conclusões:

1) que o trabalho que uma pessoa é capaz de fazer, medido pelo seu comportamento no "ergograph", mostra evidências de um declínio com o passar do tempo;

2) que a correlação entre a sensação de fadiga e o comportamento fatigado é fraca; 
3) que deve haver um mecanismo ou processo básico de fadiga que ele concebeu como uma substância produzida pelo trabalho muscular;

4) que a fadiga pode ser afetada por vários fatores contextuais incluindo outras demandas e estresse.

Mas já naquela época, Ellis e Shipe (1903), citando Bolton (sd), afirmavam, com base em experimentos de outros autores, que o método do "ergograph" não era preciso.

Lee (1994) relata que o periodo de intensa teorização sobre a fadiga começou em meados do Século $X X$, quando o fisiologista britânico Patrick Merton estudou o desenvolvimento da fadiga em um pequeno músculo da mão humana.

Quase todas as pesquisas, a partir da definição de fadiga de Mosso, em 1869, foram realizadas por fisiologistas e psicólogos. Em 1890 a fadiga passa a ser estudada em laboratórios, estabelecidos, em sua maioria, nos países europeus. As pesquisas então realizadas focalizavam principalmente a fadiga física (Wessely et al. 1998).

Hemingway (1953) achava que o corpo humano é a resultante da ação de um número considerável de forças que produzem a condição de equilibrio, e este último como uma condição essencialmente dinâmica. Isto implica em algum tipo de balanço de forças. Hemingway fornece, como exemplo, o suprimento de substâncias para a produção de energia e a taxa de energia gasta nos músculos. Segundo ele, este é um dos aspectos da manutenção da atividade neuromuscular e que uma diferença entre suprimento e demanda pode levar a um decréscimo no desempenho e aos resultados definidos como fadiga. Quando um músculo não mais consegue trabalhar no seu nível original, isto pode ser devido à dificuldade das fibras musculares de desenvolver a tensão requerida, ou a falhas nos impulsos nervosos que os atingem. A falha no mecanismo neural pode ser devida a danos de condução nas fibras nervosas, nas sinapses ou na conexão final do músculo. Hemingway conclui que se a participação do neurônio motor e 
do músculo forem consideradas, permanece a visão clássica de que a fadiga está localizada nas terminações das fibras nervosas.

$\mathrm{Na}$ década de 50, no decorrer do Século XX, não se sabia se a força muscular era limitada pelos impulsos descendentes, pela transmissão através da junção neuromuscular ou pelas propriedades contráteis das próprias fibras musculares. Patrick Merton (citado por Lee 1994) realizou um experimento que mostrou, pela primeira vez, que, em algumas circunstâncias, a base fisiológica da fadiga reside no próprio músculo. Este experimento é descrito por Lee (1994):

"... Merton estudou o músculo adutor curto do polegar. Na primeira parte do estudo, ele comparou as contrações produzidas voluntariamente e por estimulação elétrica direta do nervo que supria o músculo. Inicialmente, ele realizou o experimento nele mesmo. Isto necessitou de certa coragem porque acreditava-se que a força máxima produzida por um músculo eletricamente estimulado era muito maior do que a que poderia ser realizada por um esforço voluntário e poderia ser suficiente para romper tendōes e mesmo quebrar ossos. Merton provou que esta idéia estava errada. No seu experimento, os sujeitos puxavam o cabo de um dinamómetro tão forte quanto podiam e a força gerada era medida. Em seguida, um estimulo elétrico era aplicado no nervo até que a força máxima fosse alcançada. Finalmente os individuos repetiam suas contraçōes voluntárias.

Os resultados mostraram que a força produzida durante uma contração voluntánia máxima e uma contração máxima eletricamente estimulada eram iguais, provando que impulsos descendentes podem ativar um músculo descansado. Em outras palavras, os músculos não possuem uma força oculta. ...Nos experimentos seguintes, Merton abordou a fadiga. Os Indivíduos faziam uma contração voluntária máxima sustentada. Após alguns segundos a fadiga instalava-se e a intensidade da força diminuía, apesar do esforço dos individuos. Merton raciocinou que se a fadiga fosse devida ao declínio do comando central, a estimulação elétrica do nervo deveria reverter a situação. De fato, quando a estimulação elétrica era superposta, esta não tinha efeito algum, mostrando que a fadiga era desenvolvida no músculo.

Mas a fadiga era devida a uma falha na junção neuromuscular ou a um processo interno do músculo? Para responder a essa questão Merton mediu a atividade elétrica do músculo através de eletrodos colocados sobre a pele na altura do músculo. $O$ tamanho do potencial de ação assim obtido é uma indicação do número de fibras musculares ativadas. Assim, se o tamanho do potencial de ação diminuir é porque houve uma falha na junção neuromuscular. Năo houve mudança no tamanho do potencial de ação, mostrando que a fadiga pode ser o resultado de um processo que ocorre inteiramente dentro das células musculares". 
O experimento de Merton (1954) ofereceu uma importante prova de que a fadiga é periférica'. Se fosse central, a recuperação deveria ocorrer quando o esforço cessasse, por não haver interferência da circulação para as estruturas centrais. Mas não ocorre o retorno da força até o fluxo sanguíneo ser estabelecido para a mão e, portanto, deve ser na mão que a fadiga tem efeito. Merton concluiu que a recuperação da fadiga não acontece se a circulação no músculo for interrompida, o que mostra que a fadiga é um fenômeno periférico.

Chaffin (1973) entendia que, na época, ainda não era possivel um completo entendimento das mudanças neuromusculares associadas com o emprego de força muscular sustentada, embora existissem teorias que tentavam explicar as mudanças no desempenho. Uma delas focalizava a facilitação neuromuscular. Segundo essa teoria, um aumento na facilitação neuromuscular é diretamente interpretada pelo Sistema Nervoso Central como um desconforto em um esforço para motivar o relaxamento do músculo contraído. Outra explicação, proposta por Rodbart e Pragay (1968), citados por Chaffin (1973), é que o metabolismo dentro das fibras musculares produz uma "dor induzida por metabólitos", que são normalmente removidos do músculo pelo fluxo sanguíneo nos capilares. Durante uma contração moderada a pesada, quando o fluxo sanguíneo nutritivo está reduzido no músculo, os metabólitos se acumulam nos nociceptores ${ }^{2}$ das terminações nervosas nos músculos, o que é interpretado como dor muscular localizada. Os autores ainda afirmam que isto pode explicar porque, sob certos ciclos de trabaiho/descanso de um músculo, em certas pessoas, a dor não limita a contração.

MacFarland (1971) discute os fatores fisiológicos da fadiga e, como introdução ao tema, coloca que o tipo de fadiga causada pelo trabalho

\footnotetext{
1 Chaffin (2001) indica uma divisão da fadiga em central ou periférica dependendo do comprometimento da ativação.

${ }^{2}$ Os nociceptores geralmente são terminações livres de fibras de neurônios ganglionares sensoriais, sensiveis a estímulos de diferentes formas de energias, capazes de responder a estímulos mecânicos fortes, estímulos térmicos extremos e as substâncias químicas irritantes ou lesivas (Lent 2001, p.176178).
} 
muscular pesado seria melhor denominado de fadiga aguda. Segundo ele, a fadiga aguda resulta em um decréscimo na eficiência, é temporária e recuperável com o descanso. MacFarland aponta que alguns cientistas tentam associar a fadiga com o acúmulo de substâncias tóxicas, tais como ácido lático no sangue. Entretanto, contrapõe que o acúmulo de ácido lático como uma explicação de fadiga é muito limitada.

O fato de muitos recordes esportivos terem sido quebrados por atletas que correram com intenso esforço e acumularam grande soma de lactase em seu sangue demonstra essa restrição. MacFarland relata ainda que vários trabalhadores industriais que realizam trabalho pesado, como os mineiros, têm valores normais de lactase no sangue. Valencia (1986) afirma que os pesquisadores da fadiga têm tentado estabelecer uma relação entre - acúmulo de ácido lático intracelular e o declínio do pico de tensão no músculo, mas que isto, por si só, não prova conclusivamente que o ácido lático causa a fadiga muscular, uma vez que a taxa de recuperação não ocorre paralelamente à taxa de limpeza do ácido lático. No entanto, segundo - autor, isto confere considerável apoio para a noção de que o acúmulo do ácido lático é um precursor de fadiga.

Chalder et al. (1993) afirmam que, da perspectiva fisiológica, "fraqueza é uma diminuição na capacidade de descanso muscular, o que impede o músculo de exercer uma força máxima, enquanto fadiga é uma diminuição na capacidade de gerar uma força máxima durante a atividade muscular".

Chaffin (2001) define fadiga como qualquer redução na capacidade de exercer força num esforço voluntário. Para o autor os níveis de fadiga e os mecanismos subjacentes ao seu desenvolvimento dependem do tipo de exercício muscular, condições de alta e baixa intensidade, estáticas ou intermitentes e isométricas ou dinâmicas.

A fadiga muscular é definida por Guyton (1996) como a contração forte e prolongada de um músculo. $O$ autor explica que os estudos realizados em atletas mostram que a fadiga muscular aumenta em 
proporção quase direta com a velocidade de depleção do glicogênio muscular. Por conseqüência, a maior parte da fadiga resulta simplesmente da incapacidade dos processos contráteis e metabólicos das fibras musculares em manter a mesma produção de trabalho. Outros experimentos, entretanto, mostram que a transmissão do sinal neural através da junção neuromuscular diminui após a atividade muscular prolongada, o que reduz ainda mais a contração muscular. Além destas determinações da fadiga, Guyton (1996) acrescenta que a interrupção do fluxo sanguíneo em um músculo em contração leva à fadiga muscular quase completa em pouco mais de um minuto, dada a perda do suprimento de nutrientes, em especial a de oxigênio. Kahn e Monod (1989) afirmam que o principal fator causal da fadiga é a isquemia localizada no músculo e que esta atua não por limitação do suprimento de oxigênio ou dos substratos da energia, mas por impedir a eliminação das várias substâncias produzidas durante a contração (notoriamente, o potássio), acúmulo que perturba a conexão excitação-contração. Segundo Valencia (1986), a oclusão do fluxo sanguíneo tem um papel importante na ocorrência de fadiga, assim como o decréscimo no suprimento de energia, fatores significantes na falha dos mecanismos contráteis.

Grandjean (1988) denomina de "fadiga muscular" o fenômeno da diminuição do rendimento muscular após a exigência do músculo e aponta que, quando esta se estabelece, ocorrem alterações bioquímicas no músculo. Define a fadiga muscular como um acometimento agudo e doloroso, que o individuo sente em sua musculatura quando esta é sobrecarregada de forma localizada. Após grandes contrações musculares, - músculo exaurido apresenta uma diminuição das reservas de energia (açúcares e ligações de fósforos) e aumento de resíduos, entre eles o ácido lático e o ácido carbônico: "... durante a contração muscular acontecem processos químicos, que entre outros, fornecem energia para $\circ$ trabalho mecânico. Após a contração, durante o relaxamento ou repouso do músculo, as reservas de energias são novamente constituidas. Portanto, no músculo 
em trabalho ocorrem reações liberadoras de energia e reações reconstituintes de energia..." (é interessante aqui a relação com a condição de equilibrio proposta por Hemingway 1953). Quando o consumo de energia supera sua capacidade de reposição, acontece uma perturbação no equilibrio dos processos metabólicos que se manifesta por uma diminuição da capacidade de produção do músculo.

MacFarland (1971), na mesma linha fisiológica, propõe que a fadiga é decorrente da exaustão das reservas de energia. Em um trabalho muito exaustivo, como em uma maratona, a ingestão de glicose ajuda definitivamente a manter a eficiência. Também em exercícios rigorosos sobre uma bicicleta ergométrica, o nivel baixo de açúcar no sangue resulta em completa exaustão e dano sensorial nos individuos. Estes efeitos são rapidamente neutralizados por ingestão de glicose e os indivíduos podem continuar seus exercícios rigorosos por mais de uma hora. Os individuos que têm condição física fraca têm pouca reserva de energia e uma capacidade reduzida para transformá-la e, como os atletas, estes indivíduos podem também se beneficiar da ingestão de glicose ou algum outro combustível facilmente ingerivel entre refeições.

Valencia (1986) alega que a causa exata de fadiga muscular não è bem conhecida. Segundo ele, a falha no complexo contrátil do músculo é geralmente aceita como a razão mais plausível e o mecanismo mais importante no desenvolvimento da fadiga muscular.

Chaffin (2001) propõe uma divisão da fadiga muscular dependendo do comprometimento da ativação: fadiga central ou periférica. A estimulação muscular central ou fadiga central estaria associada com a motivação e percepção de esforço de um indivíduo e com a integridade do comando motor através dos tratos descendentes. Já os mecanismos de fadiga periférica estão associados à falência da excitação muscular e estes incluem:

1) a falência da propagação dos potenciais de ação ao longo dos axônios dos neurônios; 
2) a redução da transmissão através da junção neuromuscular e

3) o declínio na intensidade dos potenciais de ação.

Segundo Lee (1994) os fisiologistas especializados em fisiologia muscular definem a fadiga de duas formas: como uma falha para manter a força em uma contração prolongada ou como uma falha para re-atingir a força em contrações repetidas. $O$ autor propõe uma explicação para essas duas formas baseadas nos mecanismos de liberação e aproveitamento do cálcio durante as contrações.

As definições de fadiga muscular e suas teorias expressas no decorrer do século $X X$ são apresentadas no quadro 1. Este tem a intenção de fornecer ao leitor uma visão geral das definições/teorias apresentadas no decorrer do texto. 


\section{Quadro 1- Definições/teorias da fadiga muscular, segundo autor(es) e ano da publicação.}

\begin{tabular}{|c|c|c|}
\hline Autor (es) & Ano & Definição/Teoria \\
\hline Mosso A & 1896 & $\begin{array}{l}\text { A fadiga se constitui em decréscimos no desempenho decorrentes da } \\
\text { repetição de uma tarefa simples. Deveria haver um mecanismo ou processo } \\
\text { básico de fadiga que ele concebeu como uma substância produzida pelo } \\
\text { trabalho muscular. }\end{array}$ \\
\hline Hemingway $\mathrm{A}$ & 1953 & $\begin{array}{l}\text { A fadiga é definida como a resultante da ação de um número considerável de } \\
\text { fatores: a diferença entre suprimento e demanda de energia pode levar a um } \\
\text { decréscimo no desempenho. Se a participação do neurônio motor e do } \\
\text { músculo for considerada, permanece a visão clássica de que a fadiga está } \\
\text { particularmente localizada nas terminações das fibras nervosas. }\end{array}$ \\
\hline Merton P A & 1954 & $\begin{array}{l}\text { A base fisiológica da fadiga reside no próprio músculo e a fadiga é o resultado } \\
\text { de um processo que ocorre inteiramente dentro das células musculares }\end{array}$ \\
\hline MacFarland R A & 1971 & $\begin{array}{l}\text { O tipo de fadiga causado pelo trabalho muscular pesado seria melhor } \\
\text { denominado de fadiga aguda. Resulta em um decréscimo da eficiência, é } \\
\text { temporária e recuperável com o descanso. Discute a causa da fadiga como } \\
\text { decorrente da exaustão das reservas de energia. }\end{array}$ \\
\hline Valencia $\mathrm{F}$ & 1986 & $\begin{array}{l}\text { A fadiga muscular pode ser devida a uma falha de algum ou de vários } \\
\text { mecanismos neuromusculares envolvidos na contração muscular. A falha no } \\
\text { processo contrátil do músculo é aceita como o mais plausível e importante } \\
\text { mecanismo no desenvolvimento da fadiga muscular. Propōe a oclusão do } \\
\text { fluxo sangüíneo e o decréscimo no suprimento de energia como fator es } \\
\text { significantes na falha dos mecanismos contráteis. }\end{array}$ \\
\hline Grandjean E & 1988 & $\begin{array}{l}\text { Fadiga muscular é a diminuição do rendimento muscular após uma exigência } \\
\text { no músculo, resultante de alterações bioquímicas. A fadiga muscular é um } \\
\text { acometimento agudo e doloroso que o individuo sente em sua musculatura } \\
\text { sobrecarregada de forma localizada. Quando o consumo de energia supera a } \\
\text { capacidade de reposição, acontece uma perturbação no equilíbrio dos } \\
\text { processos metabólicos que se manifesta por uma diminuição da capacidade } \\
\text { de produção do músculo. }\end{array}$ \\
\hline Lee J & 1994 & $\begin{array}{l}\text { A fadiga teria duas formas: uma falha para manter a força em uma contração } \\
\text { prolongada ou uma falha para re-atingir a força em contraçōes repetidas, } \\
\text { ambas decorrentes dos mecanismos de suprimento e utilização do cálcio } \\
\text { durante as contrações. }\end{array}$ \\
\hline Guyton A C & 1996 & $\begin{array}{l}\text { Fadiga muscular é a resultante de uma forte e prolongada contração de um } \\
\text { músculo. Aumenta em proporção quase direta com a velocidade de depleção } \\
\text { do glicogênio muscular A maior parte da fadiga resulta da incapacidade dos } \\
\text { processos contráteis e metabólicos das fibras musculares em manter a } \\
\text { mesma produção de trabalho. }\end{array}$ \\
\hline Kahn JF e Monod H & 1989 & O principal fator causal da fadiga é a isquemia local do músculo. \\
\hline Chafin DB et al. & 2001 & $\begin{array}{l}\text { Fadiga é qualquer redução na capacidade de exercer força num esforço } \\
\text { voluntário }\end{array}$ \\
\hline
\end{tabular}

\section{O principal problema com as definições e estudos da fadiga localizada} é que parece não haver uma relação direta entre a fadiga muscular localizada e a fadiga generalizada, definida conceitualmente como o resultado de um processo fisiológico e psicológico, expressa pelos indivíduos durante e após o trabalho físico. Hueting e Sarphati (1966) relatam que vários autores delinearam experimentos na tentativa de medir a 
fadiga generalizada. Contudo, a conceituação e a realização de experimentos sobre o que é relatado como sensação de fadiga geral são consideradas de difícil operacionalização.

Como conseqüência das pesquisas da fadiga localizada emergiu a compreensão de que apenas esta causa não justificaria o estado de uma pessoa fadigada. Mosso (1896) já apontava uma sobrecarga mental como uma das causas da fadiga. Via a questão da fadiga se tornando mais e mais complexa e não conseguia enumerar todas as causas que podiam produzir 0 fenômeno. Muscio (1921b) alertou para a questão de a fadiga não ser puramente física e propôs uma separação entre fadiga muscular e fadiga mental. Verificou que um alerta mental estaria várias vezes relacionado a certa tensão muscular. As pesquisas se ampliaram para entender a fadiga como um fenômeno complexo, pois a questão da fadiga não poderia ser explicada somente por um quadro de fadiga muscular localizada decorrente de movimentos musculares repetidos.

\subsection{A Fadiga Generalizada}

A inadequação em estabelecer a causa da fadiga como localizada em um músculo jả havia sido discutida por Smith (1915-1917). Este autor apontou as dificuldades em medir fadiga porque "os sinais de fadiga diferem de acordo com o indivíduo" e que os testes usados não se mostravam adequados.

Durante a $1^{\mathrm{a}}$ Guerra Mundial $\mathrm{o}$ interesse na fadiga como uma inabilidade para manter o trabalho físico tornou-se um contínuo entre os pesquisadores, principalmente na Inglaterra. $O$ interesse neste período estava voltado para a produtividade na indústria, principalmente a de munição. Os estudos tratam de tópicos tais como: horas de trabalho, sistema de troca de turnos, iluminação, ventilação e desenho do local de trabalho (Cameron, 1973). A situação de guerra modificou as jornadas de trabalho. Chambers (1961) ressalta que entre 1914 e 1918 as jornadas de trabalho 
aumentaram para 70-90 horas por semana e, algumas vezes, ultrapassavam 90 horas. Pausas voluntárias para descanso e recuperação da musculatura eram introduzidas, mas em número insuficiente. Quando se estudava a produção dos trabalhadores detectava-se que essa produção era limitada pela fadiga e que o alivio da fadiga, através de qualquer medida, deveria capacitar a produção para que fosse mantida em um nivel alto. Assim, os trabalhos realizados nesse período não se preocupavam com os aspectos teóricos da fadiga e o conceito foi sendo cristalizado no contexto de práticas de produção (Cameron 1971).

Muscio (1921a, 1921b), um dos pioneiros dos estudos sobre a sensação de fadiga na indústria, acreditava que a sensação de fadiga não é um critério confiável da "capacidade de trabalho". O que Muscio enfatiza é que podemos sentir-nos mentalmente fatigados sem estarmos fatigados fisicamente. A discussão sobre a relação entre a sensação de fadiga e o estado fatigado (mudança no desempenho) traz à tona a dificuldade em se chegar a uma concepção plausível da existência de uma condição fisiológica desta sensação. Como conceber a relação entre a sensação de fadiga e os resultados do rendimento de produção?

Muscio (1921a), ao mesmo tempo em que apresenta sua definição de fadiga, propõe o abandono do termo por não ter uma definição satisfatória e questiona: "... no nosso entendimento o que é fadiga?" e ainda afirma: "... como podemos encontrar um teste para uma entidade indefinida?".

Tanto Smith (1915-1917) quanto Muscio (1921a, 1921b), ambos psicólogos ingleses, abordam a fadiga como um fenômeno mais amplo do que puramente uma diminuição no rendimento produtivo por sobrecarga muscular. A partir dessa idéia, a abordagem da fadiga torna-se mais complexa. A fadiga passa a ser vista de outras formas que não simplesmente uma dor localizada em um músculo sobrecarregado.

Em 1917, o Conselho de Investigação Médica (Medical Research Council) e o Departamento de Investigação Cientifica e Industrial (Department of Scientific and Industrial Research), ambos ingleses, atuando 
conjuntamente, criaram a Junta de Investigação da Fadiga Industrial (Industrial Fatigue Research Board). Em 1921, estes primeiros esforços se completaram com a criação, em Londres, de um Instituto de Psicologia Industrial (National Institute of Industrial Research). O fundador do Instituto, Dr C. S. Myers ${ }^{3}$, era um dos membros da Junta de Fadiga. Em 1930 o nome da Junta foi trocado para Junta de Investigação da Saúde Industrial (Industrial Health Research Board), suprimindo de seu título a palavra "fadiga". Mayo (1959) cita Cathcart (1928) ${ }^{4}$ que questionava o significado da palavra fadiga e do conceito de fadiga industrial, dizendo que, este último conceito não é mais claro do que o de fadiga comum, que ainda não podia ser explicada. Para Cathcart (1928), citado por Mayo (1959), a melhor definição para a fadiga industrial é que ela consiste em uma capacidade reduzida para o trabalho. Cathcart ainda adverte que a fadiga "não pode definir-se como uma entidade única e limitada".

Cameron (1973) analisa uma segunda área de interesse dos pesquisadores da fadiga que apareceu durante as décadas de 40 e 50 . $O$ foco destes trabalhos foi a aviação, principalmente a militar. Representantes deste periodo, como Bartlett (1943), Drew (1940) e Davis (1946, 1948) e Viteles, citados por Cameron (1973), empregaram critérios mais complexos, em suas pesquisas, do que simples figuras de rendimento produtivo. A preocupação passa a ser com o padrão de colapso da capacidade de trabalho. Segundo Cameron, Bartllet, Drew e Davis empregaram uma rigorosa abordagem experimental, preocupada quase que exclusivamente com os presumidos efeitos da fadiga sobre o desempenho. Os efeitos das condições fatigantes sobre o desempenho, no entanto, foram considerados somente no geral, eles não se interessaram pelas sensações subjetivas daqueles que tomaram parte em seus experimentos. Já o trabalho de Viteles, citado como Relato Vitelles, reconheceu a dificuldade de interpretar

\footnotetext{
${ }^{3}$ Mayo (1946) cita o trabalho do Dr C. S. Mayers: Charles S. Mayers, Industrial psychology, New York, the People's Institute Publishing Company, Inc. 1926, p 44.

${ }^{4}$ Idem para Cathcart: E. P. Cathcart, The Human Factor in Industry, Londres, Oxford University, 1928 , p. 17.
} 
e aplicar os resultados de estudos experimentais e declarou claramente que o desempenho não deveria se a única área de interesse. O que o Comitê Vitlles observou sobre fadiga foi mais amplo e mais humano, pois levava em conta as sensações subjetivas dos envolvidos. Em 1947, Bartley e Chute (citados em Cameron 1973 e em Wessely et al. 1998) publicaram uma monografia, tendo como base o material do Comitê Viteles, mas fazendo uma análise muito mais complexa da fadiga. Cameron (1973) faz a seguinte referência que denota a importância da monografia de Bartley e Chute:

\footnotetext{
“... Eles enfatizaram a natureza complexa da fadiga e apontaram três facetas distintas do problema. Consideraram que o termo fadiga deveria ser usado somente para descrever a sensação subjetiva de lassidão e aversão à atividade com característica de sofrimento individual de fadiga e propuseram a depreciação do termo para identificar a redução da capacidade física resultante de um aumento do débito de oxigênio no tecido muscular. Designaram a deterioração na qualidade do desempenho, por razōes outras que não a incapacidade física, como decréscimo no trabalho. Apontaram que estes três aspectos do estado de fadiga estão complexamente relacionados. A presença de um aspecto não deve ser inferida com segurança a partir da presença de um ou de ambos os outros. Embora não tenham chegado a uma satisfatória definição prática de fadiga ou clarificado uma terminologia que poderia ser adotada por outros pesquisadores, Bartley e Chute introduziram uma nova e importante ênfase sobre os efeitos crônicos da fadiga: apontaram que, na prática clinica, a fadiga crónica, não dissipada por um processo normal de descanso e recuperação, é um problema comum. Debilitação ou decréscimo no trabalho, capaz de ser suplantado pelo descanso, não apresenta nenhum problema prático sério. Suas análises $e$, principalmente, sua distinção entre os efeitos crônicos e agudos influenciaram consideravelmente a conceituação da fadiga e sua monografia tem sido uma referência na longa e confusa história das pesquisas sobre a fadiga".
}

Holding (1984) propõe a distinção entre fadiga subjetiva, objetiva e fisiológica. A fadiga objetiva aparece no resultado do trabalho, são dados de desempenho, isto é, do declínio deste em todos os tipos de atividades de conhecida sobrecarga. O termo deterioração deve ser reservado para mudanças fisiológicas ao nível dos tecidos, incluindo mudanças nas funções neural e motora (fadiga fisiológica). Tudo aquilo que sobra para designar fadiga propriamente dita é a sensação subjetiva de desconforto corporal e aversão ao esforço (fadiga subjetiva). Holding (1984) cita ainda que Bartley e 
Chute acreditavam que a fadiga representa uma forma de conflito: o conflito entre as demandas das tarefas e a aversão do individuo ao esforço.

Entendendo que outros fatores estariam compondo o quadro de uma fadiga generalizada, associado a decréscimos no desempenho, Bartley e Chute, em 1947, (citados em Wessely et al. 1998), definiram os principais componentes da fadiga, indicando a separação de um conceito global em componentes mensuráveis. Os componentes propostos foram:

(1) Comportamental: um decréscimo no desempenho, se desdobrando em diminuição no desempenho fisico e decréscimo no desempenho mental;

(2) Sensação de fadiga: que pode ser pesquisada via vários sinônimos tais como falta de energia, fraqueza, sonolência e falta de motivação;

(3) Mecanismos ou variáveis intervenientes: fatores que ocorrem nos niveis bioquímico, fisiológico e psicológico;

(4) Contextual: referente à situação onde ocorre a fadiga, levando ao estudo dos fatores ambientais, tanto físicos quanto culturais, causadores da fadiga.

Os efeitos da fadiga sobre o desempenho são discutidos por Welford (1953). Ele aponta a dificuldade dos psicólogos com o problema de medir a fadiga, pois eles voltam sua atenção para as manifestações da fadiga em algum tipo de decréscimo na atividade e é neste ponto que o problema se inicia. Uma importante contribuição de Welford é a definição de pelo menos três tipos de efeitos da fadiga sobre o desempenho:

1) o simples decréscimo no desempenho;

2) a desorganização do desempenho e

3) a ruptura cumulativa do desempenho.

O primeiro pode ocorrer em algumas tarefas onde a fadiga aparece como um franco decréscimo em um ou mais aspectos do desempenho. Este tipo de efeito aparece em situações onde duas características estão presentes: (a) o aspecto da tarefa que se está medindo pode variar sem afetar outros aspectos, por exemplo, a velocidade pode variar sem afetar a precisão e (b) a tarefa é repetitiva, no sentido de que a velocidade, a precisão e o efeito de cada ação realizada não são dependentes do resultado de ações prévias, exceto no fato de que uma ação deve ser 
completada antes da próxima se iniciar. O segundo tipo de efeito diz respeito às tarefas não repetitivas, mas que consistem de ações dentro de uma grande seqüência ou séries de ações. Este tipo de organização é característico de trabalho especializado. Nesse caso, os efeitos da fadiga aparecem como uma diminuição na coordenação das ações. $O$ terceiro tipo de efeito de fadiga ocorre quando o desempenho é contínuo e a variação de um aspecto afeta outro, por exemplo, a lentidão diminui a precisão, e onde a tarefa é composta por uma série de ações, onde cada ação é dependente da última e tem implicações na próxima.

Segundo Borg (2000), fadiga em termos amplos se refere a um estado que poderia ser chamado de "sonolência" ou alto nivel de cansaço ou exaustão. Neste estado pode ocorrer uma diminuição no desempenho do indivíduo. De fato o termo fadiga (grifo do autor) é freqüentemente empregado em situações "em que uma redução temporária da capacidade de trabalho resulta de uma atividade física precedente (Asmussen 1979, citado por Borg 2000)". Assim, a fadiga é definida em termos fisiológicos ou em relação à diminuição no desempenho, e não em termos perceptivos. $O$ estudo de fadiga somente a partir de uma perspectiva fisiológica é tão impossivel quanto lidar com a cor, emoção ou motivação em termos basicamente físicos, ou fisiológicos. Ou seja, a fadiga é um estado que tem aspectos tanto fisiológicos quanto psicológicos.

Em uma pesquisa multidisciplinar sobre fadiga no trabalho, desenvolvida em 1966 pela Organização para a Pesquisa Científica da Holanda, a fadiga foi definida como: "uma mudança no mecanismo de controle psicológico que regula o comportamento na tarefa, resultante de um esforço mental elou físico, que se torna de tal forma incômodo que o individuo não é mais capaz de responder adequadamente à demanda sobre a sua função mental, ou que é capaz de responder a essa demanda somente através de um aumento do esforço mental e a superação da resistência (Beurskens 2000)". 
Cameron (1973) acredita que a fadiga deve ser considerada como tendo efeitos crônicos e agudos. Os primeiros parecem ser de grande significância prática e são caracteristicamente encontrados na sensação subjetiva de lassidão e cansaço comumente descrita como fadiga. Os efeitos sobre o desempenho são mais provavelmente agudos: a recuperação tende a ocorrer após um periodo relativamente breve de descanso. Cameron (1973), seguindo a linha de uma análise histórica dos estudos sobre a fadiga, aponta uma mudança de ênfase, passando-se de uma abordagem quase exclusiva de medidas diretas dos resultados produtivos para a definição de quais condições afetam adversamente o desempenho, e chegando-se ao reconhecimento da fadiga como um problema pessoal do individuo. Assim, segundo ele, deve-se entender a fadiga como reações individuais ao estresse sobre um período de tempo. $O$ autor afirma que se esta conclusão é correta então é obvio que a fadiga é um problema que não pode ser definido em termos de condições de exposição e tem origem no estado pessoal do individuo. Conclui dizendo que um ponto apropriado para iniciar as pesquisas sobre fadiga é o volume de queixas daqueles expostos a um particular conjunto de condições de trabalho.

Holding (1984) concorda com a posição de Cameron (1973) de que a fadiga é uma resposta generalizada ao estresse sobre um periodo do tempo, ressaltando a importância de variáveis como ansiedade e reafirmando a forte relação entre a fadiga e distúrbios do sono.

Para Grandjean (1968) a fadiga, em sua origem, não é um termo científico, mas designa uma sensação bem conhecida na experiência diária. $\mathrm{Na}$ prática, todos sabemos, de nossa experiência, que o cansaço pronunciado do dia a dia pode, se prolongado, ocasionar o estado de fadiga crônica. Quando isso acontece a sensação de cansaço é intensa, aparecendo não somente no anoitecer, após o trabalho, mas durante o trabalho e mesmo antes deste iniciar. A sensação, acompanhada de repugnância, é de natureza emocional. Cameron (1973) também relata o envolvimento de ansiedade e medo ou de pelo menos algum estado 
emocional similar na síndrome da fadiga. Ainda segundo Grandjean (1979), o termo fadiga denota diminuição de eficiencia e aversão a qualquer tipo de esforço. Sobre o esforço, Ryan (1953) relata que o grau de esforço colocado em uma tarefa parece ser um dos determinantes primários da quantidade de fadiga resultante dele e que o termo esforço está associado à questão dos incentivos e motivação para o trabalho. O esforço é entendido por Ryan como a experiência do indivíduo, como ele trabalha. Ele sente em certos momentos que ele está "trabalhando pesado" e em outros que está "trabalhando leve". O esforço também inclui a experiência da dificuldade de manutenção da atenção durante uma tarefa monótona e o esforço em desempenhar um trabalho desagradável ou repugnante.

Grandjean (1988) afirma que a fadiga, como uma experiência rotineira, não é um estado definido nem unitário. O conceito também não é claro quando nos referimos à "fadiga do trabalho", "fadiga mental", "fadiga física" etc. O autor acredita que a multiplicidade de usos da expressão "fadiga" levou a uma quase caótica organização dos conceitos, mas ainda credita significância à distinção feita entre a fadiga muscular e a fadiga generalizada. Define a fadiga generalizada como uma sensação difusa acompanhada de uma indolência e falta de motivação para qualquer atividade. É um estado funcional que vai constantemente para o lado do estado de sono e para outro lado de um estado de descanso. Isto porque o organismo encontra-se em cada instante em um determinado estado funcional que está situado entre dois pólos opostos: entre o sono e o estado de alerta. Segundo ele, no estado de fadiga fica a sensação subjetiva de cansaço:

"... nos sentimos travados e nossas atividades são inibidas até quase a paralisação. Nós não temos motivação nem para o trabalho físico nem para o mental, nos sentimos pesados e indolentes. A sensação de cansaço não é desagradável quando podemos descansar, é doloroso quando não nos concedemos repouso. A simples observação já estabeleceu, há tempos, que sob o ponto de vista geral, a sensação de cansaço é, assim como a sede, a fome e sensações análogas, um 
mecanismo de proteção, enquanto objetiva proteger 0 homem de maiores sobrecargas. A sensação de cansaço obriga as pessoas a evitar novas sobrecargas, para que os processos normais de restabelecimento possam acontecer em todo organismo". ( $p$. 159)

Para a fadiga generalizada Grandjean (1988) resume seu conceito nos seguintes termos:

"... o nivel de prontidão é um estado que atua em algum ponto entre os dois extremos de sono e um estado máximo de alerta. Os mecanismos de controle na medula espinhal, o mesencéfalo e estruturas do tálamo regulam este estado e 0 ajusta conforme a demanda momentânea do organismo. Se as influências externas são dominantes então o sistema de ativação prevalece; 0 indivíduo sente-se estimulado igual a um estado de alerta e é direcionado para a ação, tanto fisiologicamente quanto mentalmente. Se, entretanto, as influências inibidoras internas ao corpo predominam, então os sistemas amortecedores prevalecem e 0 indivíduo sente-se sem energia, sonolento e letárgico". (p. 166).

A formação reticular está localizada nas partes profundas do cérebro se estendendo do bulbo até o mesencéfalo. É uma estrutura nervosa que tem função importante no comando dos estados emocionais. Não é uma estrutura unitária e não possui um único papel. A formação reticular está envolvida em muitas funções neurais automáticas ou inconscientes. Várias partes desta formação regulam o tônus postural, os reflexos oculares, o estado consciente (por exemplo, vigília/sono) e a atividade autônoma. Tanto a estimulação sensorial quanto os esforços conscientes poderiam ativar o sistema reticular para manter a vigília (Kolb e Wishaw 2002; lyer et al. 2001; Lent 2001 e Grandjean 1988). Grandjean (1988) propõe uma ligação entre o Sistema Reticular de Ativação e o Sistema Límbico, sendo que o Sistema Límbico é o sistema motivacional do cérebro que nos desperta da inatividade e põe em ação nossas seqüências de movimentos.

Grandjean (1988) propõe que as causas da fadiga generalizada são de natureza muito variada e as mais importantes são: a intensidade e 
duração do trabalho físico e mental; o ambiente, clima, luz e ruido; causas psiquicas, responsabilidade, ansiedade ou conflitos; doenças e dores; e alimentação. $O$ autor faz uma analogia, mostrando a fadiga no organismo como um líquido em um tonel. Líquido este que é entomado para o tonel em conseqüência da soma dos fatores de exposição. Os sintomas da fadiga, objetivos e subjetivos, podem ser: as sensações de cansaço, sonolência, lassidão e falta de disposição para o trabalho; a dificuldade para pensar; a diminuição da atenção; a lentidão e amortecimento das percepções; a diminuição da força de vontade; e perda de produtividade em atividades físicas e mentais.

Milosevic (1997) e Holding (1984) acreditam que "não há necessidade de abandonar o conceito de fadiga". Esses autores descrevem a fadiga como um decréscimo no desempenho e sensações subjetivas de cansaço, após um trabalho prolongado e estressante.

Wessely et al. (1998) mencionam que o problema com a definição da fadiga é decorrente de uma falha em diferenciar seus vários componentes e significados. Assim, os autores fazem uma divisão da fadiga em componentes:

(1) Comportamento resultante do trabalho;

(2) Estado ou sensação de fadiga, abrangendo os niveis mental e físico, levando em consideração a sua severidade e qualidade, bem como sintomas associados;

(3) Componentes afetivo e avaliativo, que envolve a definição de agradável/desagradável, ou seja, o prazer e o desprazer, e a ansiedade e depressão associadas ao estado de fadiga, como percebidos pelo sujeito;

(4) Componentes cognitivos e emocionais resultantes do estado de fadiga;

(5) Estado interno de fadiga, envolvendo mecanismos fisiológicos, bioquimicos e psicológicos;

(6) Ambiente de uma pessoa fatigada, levando em consideração as demandas desse ambiente e do contexto em que ocorre a fadiga, abrangendo os fatores físicos, como ruído e temperatura, os estressores sociais e o contexto cultural.

Beurskens (2000), seguindo a linha de Lewis e Wessely (1992), considera a fadiga como uma sensação subjetiva com componentes emocionais, comportamentais e cognitivos. $\mathrm{O}$ autor aponta que há uma 
diferença essencial entre fadiga aguda e fadiga crônica. A fadiga aguda é caracterizada por reversibilidade, problemas especificos e um uso funcional de mecanismos de compensação. A fadiga aguda é um fenômeno normal que desaparece após um periodo de descanso. Em contraste, a fadiga crônica é irreversivel a um curto prazo, não apresenta especificidade e os mecanismos de compensação usados para a fadiga aguda não produzem efeitos sobre a fadiga crônica.

A Organização Mundial de Saúde (1993) na Classificação Internacional de Doenças, em sua Décima Revisão (CID 10), classifica a fadiga em três grandes grupos da Lista de Categorias de Três Caracteres: no Capítulo V: Transtornos Mentais, como Neurastenia (F48.0) e no Capitulo XVIII: Sintomas, sinais a achados anormais de exames clínicos de laboratório, não classificados em outra parte e Sintomas e sinais gerais, como Mal estar, fadiga (R53). No Capítulo XXI: Fatores que influenciam o estado de saúde e o contato com os serviços de saúde e Problemas relacionados com a organização de seu modo de vida, classificada como Estafa (Z73.0) e está se referindo a um esgotamento, um estado de exaustão vital.

No Capítulo $\mathrm{V}$ a Neurastenia é assim definida:

"Existem variações culturais consideráveis para a apresentação deste transtorno, sendo que dois tipos principais ocorrem, com considerável superposição. No primeiro tipo, a característica essencial é a de uma queixa relacionada com a existência de uma maior fadigabilidade que ocorre após esforços mentais freqüentemente associada a uma certa diminuição do desempenho profissional e da capacidade de fazer face às tarefas cotidianas. A fadigabilidade mental é descrita tipicamente como uma intrusão desagradável de associações ou de lembranças que distraem, dificuldade de concentração e pensamento geralmente ineficiente. No segundo tipo, a ênfase se dá mais em sensações de fraqueza corporal ou fisica e um sentimento de esgotamento após esforços minimos, acompanhados de um sentimento de dores musculares e incapacidade para relaxar. Em ambos os tipos há 
habitualmente vários outras sensações físicas desagradáveis, tais como vertigens, cefaléias tensionais e uma impressão de instabilidade global. São comuns, além disto, inquietudes com relação a uma degradação da saúde mental e física, irritabilidade, depressão e ansiedade menores e variáveis. $O$ sono freqüentemente está perturbado nas suas fases inicial e média, mas a hipersonia pode também ser proeminente".

No Capitulo XVIII o Mal estar, fadiga, engloba sob esta insígnia a Astenia SOE ${ }^{5}$; Cansaço; Debilidade SOE, crônica e nervosa; Deterioração física geral e Letargia. Ainda na CID 10 podemos encontrar uma morbidade classificada como fadiga, que é a Estafa (Z73). A estafa esta classificada no Capítulo XXI: Fatores que influenciam o estado de saúde e o contato com os serviços de saúde.

Seguindo os mesmos passos da apresentação da fadiga muscular produzimos o Quadro 2 que poderá facilitar a compreensão do desenvolvimento das definições e teorias sobre a fadiga generalizada.

\footnotetext{
${ }^{5}$ As letras SOE são uma abreviação de "Sem Outras Especificações", implicando "não especifico"ou não qualificado". (Organização Mundial de Saúde - Classificação Estatística Internacional das Doenças e Problemas Relacionados a Saúde: Décima Revisão 1994)
} 
Quadro 2- Definições e teorias sobre a fadiga generalizada, segundo autor(es) e ano da publicação.

\begin{tabular}{|c|c|c|}
\hline Autor (es) & Ano & Definição/Teoria \\
\hline Muscio B & $1921 a$ & $\begin{array}{l}\text { Aponta a natureza intrínseca da fadiga. A fadiga é definida como aquela } \\
\text { condição na qual certa porcentagem de energia orgânica pode ser } \\
\text { transformada em calor ou trabalho e por outro lado a fadiga pode ser definida } \\
\text { como aquela condição na qual certos produtos químicos da atividade, da } \\
\text { natureza dos venenos orgânicos, são acumulados nos orgãas que estão } \\
\text { ativos: diferentes graus de fadiga significam diferentes produtos da atividade. }\end{array}$ \\
\hline Mayo E & 1959 & A fadiga consiste em uma capacidade reduzida para o trabalho. \\
\hline Bartley e Chute & 1947 & $\begin{array}{l}\text { A fadiga representa uma forma de conflito. } 0 \text { conflito ocorre entre as } \\
\text { demandas das tarefas e a aversâo do individuo ao esforço. }\end{array}$ \\
\hline Cameron C & 1973 & $\begin{array}{l}\text { A fadiga possui efeitos crônicos e agudos. Os primeiros parecem ser de } \\
\text { grande significância prática e são encontrados na sensação subjetiva de } \\
\text { lassidão e cansaço comumente descrito como fadiga. Os efeitos sobre o } \\
\text { desempenho são provavelmente agudos. A recuperaçấo para um nivel normal } \\
\text { tende a ocorrer após um período relativamente breve de descanso. }\end{array}$ \\
\hline Holding DH & 1984 & A fadiga é uma resposta generalizada ao estresse sobre um periodo no tempo \\
\hline Kenedy HG & 1987 & $\begin{array}{l}\text { A fadiga é um decréscimo no desempenho que ocorre quando se realiza } \\
\text { qualquer tarefa de forma repetitiva e prolongada. }\end{array}$ \\
\hline Grandjean E & 1988 & $\begin{array}{l}\text { A fadiga generalizada é uma sensação difusa acompanhada de uma } \\
\text { indolência e falta de motivação para qualquer atividade. Desenvolve um } \\
\text { modelo neurofisiológico. Demonstra que a fadiga no organismo é } \\
\text { consequêencia de uma soma de fatores. }\end{array}$ \\
\hline $\begin{array}{l}\text { Holding DH } \\
\text { Milosevic S }\end{array}$ & $\begin{array}{l}1984 \\
1997\end{array}$ & $\begin{array}{l}\text { A fadiga é um decréscimo no desempenho e, também, sensaçōes subjetivas } \\
\text { de cansaço, após um trabalho prolongado e estressante. }\end{array}$ \\
\hline Borg G & 2000 & $\begin{array}{l}\text { A fadiga se refere a um estado que poderia ser chamado de "sonolência" ou } \\
\text { alto nivel de cansaço ou exaustấ. Nesse estado pode ocorrer uma } \\
\text { diminuiçâo na capacidade de desempenho do indivíduo. }\end{array}$ \\
\hline
\end{tabular}

Apesar das pesquisas desenvolvidas nas últimas décadas permanece o reconhecimento do problema da definição da fadiga. Em muitos estudos sobre a fadiga os autores não definem qual o marco conceitual que eles estão utilizando para realizar a sua pesquisa (Maitra e koyal 1971, Malmqvist et al. 1981, Habes 1985, Christensen 1986, Baidya e Stevenson 1988, Raggatt and Morrissey 1997, Metzner 2000), mesmo quando apontam a dificuldade de definição. Esta dificuldade é citada por Schwab (1953) quando afirma que a fadiga é a mais familiar de todas as experiências e ainda é a 
mais difícil de definir, e por Peres et al. (2002) que referem ser a fadiga um sintoma comum, mas sua falta de definição e sua natureza subjetiva dificultam seu estudo.

Smith (1915-1917) questionou, no início do século passado, se era possivel medir fadiga objetivamente e quais eram os efeitos da fadiga sobre o real estado fatigado. Também lançou um questionamento sobre qual é a relação entre a experiência de fadiga de uma pessoa fatigada e a fadiga estimada por uma medida objetiva. Esta é uma questão que a nosso ver não encontrou resposta até o presente momento.

Cameron (1973) conclui que considerar o conceito de fadiga como desnecessário é uma curiosa finalização para a tentativa de desenvolver uma teoria de fadiga. Pode haver alguma significância no fato que as evidências conduzem para a mesma conclusão (citando Browne 1953, "Fadiga: fato ou ficção?" e Muscio 1921a), mas o problema da fadiga não pode ser simplesmente eliminado por defini-la como inexistente.

\subsection{A Fadiga Crônica}

Outra área de interesse no campo da fadiga é a fadiga crônica e a síndrome da fadiga crônica. Segundo Wessely et al. (1998) e Souza (2002), a fadiga crônica é uma fadiga severa com redução da capacidade funcional do indivíduo, não aliviada pelo descanso, com a duração de seis meses ou mais.

A condição clínica conhecida como síndrome da fadiga crônica recebeu atenção da medicina, da saúde alternativa e comunidades psicológicas na década passada. O termo "síndrome da fadiga crônica" foi cunhado em 1988 quando o Centro de Controle de Doenças dos Estados Unidos (Center for Disease Control - CDC) reconheceu uma condição clínica caracterizada como fadiga física e mental severa, usualmente com quadro agudo, exacerbado pela atividade física (Lehman et al. 2002). 
Segundo Fukuda (1994), citado por Short et al. (2002), um grupo de trabalho do CDC desenvolveu uma definição modificada. Esta definição perfilou características da fadiga e um conjunto prevalente de outros sintomas reumatológicos, infecciosos e neurológicos.

Um dos maiores problemas não solucionados, e consequente criticismo, é o da definição de síndrome de fadiga crônica e do papel dos sintomas somáticos e a relação com os distúrbios psiquiátricos. Para definir fadiga crônica o critério requer que o clínico inquira rotineiramente sobre fadiga e exclua grande número de distúrbios, tanto físicos quanto psiquiátricos. Se o diagnóstico de depressão maior ou outra condição psiquiátrica é feito, então o individuo não pode ser considerado como sendo um caso de sindrome de fadiga crônica. Existem objeções para esta estratégia de definição. Uma delas aparece claramente em pelo menos metade dos estudos de pacientes com síndrome da fadiga crônica, pois estes também satisfazem critérios para distúrbios psiquiátricos (Wessely et al. 1998).

Há evidências que a fadiga crônica está fortemente associada com distúrbios psiquiátricos. Há muitas explicações plausiveis desta associação. Primeiro que a fadiga é a causa de distúrbios psiquiátricos subseqüentes. As pessoas se tornam deprimidas porque estão cansadas. A segunda é que os distúrbios psiquiátricos levam à fadiga, por exemplo, uma pessoa se torna inativa porque ela esta deprimida, e sucessivamente se torna fatigada. Finalmente, ambas, fadiga e distúrbios psiquiátricos, têm origem comum (Wessely et al. 1998).

O trabalho visando a definição da Síndrome da Fadiga Crônica desenvolvido pelo CDC (1988) foi um passo importante, avançado, mas não definiu efetivamente a distinção da síndrome da fadiga crônica de outros tipos de fadiga crônica inespecifica (Lee 1998). Em 1993 o CDC reuniu um grupo de pesquisadores que desenvolveu uma definição da síndrome da fadiga crônica, separando claramente estas dos casos de fadiga crônica idiopática. A sindrome da fadiga crônica foi definida como fadiga persistente 
ou reincidente nos últimos 6 meses consecutivos. Além disso, quatro ou mais dos seguintes sintomas têm de estar presentes: (1) debilidade de memória ou concentração, (2) garganta irritada, (3) dolorimento cervical, pontos de dor na cervical ou linfonodos axilares, (4) dor muscular, (5) dor articular múltipla, (6) episódios recentes de dores de cabeça, (7) sono não reparador e (8) indisposição pós-exercício (Lee 1998).

Devido à importância da fadiga crônica, considerada como um sintoma presente em várias doenças, tais como fibromialgia, depressão, esclerose múltipla, apnéia do sono, lupus eritematoso sistêmico, dor de cabeça (Peres et al. 2002), cabe aqui apresentar algumas doenças e suas relaçōes com a fadiga, a fim de contribuir para o entendimento da abrangência do conceito de fadiga, embora não seja nosso objetivo, neste trabalho, discutir a fadiga crônica e as doenças relacionadas a ela.

\subsection{A Prevalência da Fadiga}

Wessely et al. (1998) citam várias pesquisas nacionais sobre a fadiga na população em geral: na França e Argélia, a fadiga aparece como um sintoma comum em donas de casa; $26,2 \%$ da população alemã relataram ter experenciado "estado de fadiga e exaustão" durante um período de sete dias; $24 \%$ de uma amostra populacional americana relataram excessiva fadiga; $22 \%$ dos mexicanos americanos referem estados de fadiga ou excessivo cansaço; $17 \%$ dos Taiwaneses relatam fadiga. Em uma amostra comunitária na Finlândia, $16 \%$ dos entrevistados relataram excessivo cansaço.

Dois estudos sobre a prevalência de fadiga são citados por Wessely et al. (1998) por abordarem com maiores detalhes a situação de fadiga. Um é o estudo realizado sobre morbidade psiquiátrica no Reino Unido, onde $27 \%$ da população adulta estudada ( $33 \%$ das mulheres e $22 \%$ dos homens) relataram significante fadiga na semana antes da entrevista. $O$ outro estudo é sobre Saúde e Estilo de Vida na População também realizado no Reino 
Unido. Neste último, a pesquisa contemplou a população adulta acima de 18 anos. Foi selecionada uma amostra representativa da população de 12254 adultos, dos quais, 9003 concordaram em responder a um questionário sobre saúde geral com 30 itens. A fadiga foi avaliada através da resposta a um único item, incluído como um item do questionário: "No último mês você sofreu de sensação de cansaço?". O resultado obtido é apresentado na Tabela 1. Como no estudo citado acima, as mulheres relatam mais cansaço que os homens e, em média, $24,4 \%$ da população estudada relataram cansaço no último mês.

Tabela 1- Prevalência de fadiga: Pesquisa de Saúde e Estilo de Vida.

\begin{tabular}{l|cc}
\hline Faixa Etária (anos) & $\begin{array}{c}\text { Homens }(\boldsymbol{n}=3905) \\
\%\end{array}$ & $\begin{array}{c}\text { Mulheres }(\boldsymbol{n}=5098) \\
\%\end{array}$ \\
\hline $18-24$ & 21.7 & 34.6 \\
$25-34$ & 19.1 & 33.0 \\
$35-49$ & 18.7 & 30.8 \\
$50-64$ & 18.8 & 26.3 \\
65 e mais & 17.6 & 26.1 \\
\hline Total & 19.0 & 29.8 \\
\hline
\end{tabular}

Fonte: Wessely et al. $1998, p .25$.

Lewis e Wessely (1992) indicam que as pesquisas populacionais têm mostrado repetidas vezes que queixas de fadiga são extremamente comuns em paises desenvolvidos. Nos Estados unidos, em uma pesquisa sobre Saúde e Nutrição, a prevalência de fadiga foi de $14,3 \%$ nos homens e $20,4 \%$ nas mulheres. Os autores apontam que parece ser relevante o fato de várias pesquisas encontrarem queixas de fadiga entre 2 a 3 vezes mais prevalentes nas mulheres do que nos homens. Sobre este tema Besing et al. (1999) desenvolveram um estudo na tentativa de identificar as diferenças de gênero na ocorrência de fadiga. Esta pesquisa teve lugar junto a um inquérito nacional sobre morbidade realizado no Holanda. A amostra foi composta por 4681 homens e 4698 mulheres. Foram pesquisados aspectos referentes a fatores biológicos, psicológicos e sociais. 0 
instrumento usado para coleta de dados foi um questionário que abordou a fadiga nas últimas semanas, condição de vida, saúde física, problemas psicossociais. Os resultados mostraram que as mulheres relatam mais fadiga do que os homens: $37,8 \%$ contra $24,3 \%$. Em ambos os sexos, idade e educação estavam significantemente relacionados à fadiga. Cuidar de crianças com idade abaixo de 6 anos foi um fator significante somente para as mulheres. Os autores colocam como prováveis explicações a mudança ocorrida na distribuição de emprego entre homens e mulheres, tendo hoje mais mulheres empregadas do que antes; e o fato de que cuidar de crianças jovens é ainda uma tarefa da mulher. $O$ estudo mostrou que mulheres desempregadas, sem crianças, parecem ter menos queixas de fadiga (35\%). A alta prevalência de fadiga é encontrada entre mulheres que combinam o trabalho e o cuidado de crianças jovens. A dupla jornada mostra ser um fator de risco para a fadiga. Um outro dado do estudo aponta para o fato de que na mulher a fadiga está relacionada a problemas de contracepção, menstruação e gravidez, fatores que não afetam o homem. Jenny Popay (sd), também citado por Wessely et al. (1998), encontrou a mesma relação entre sintomas de fadiga e o cuidado de crianças abaixo de 6 anos em mulheres. Assim, as mulheres têm razão em se sentir mais fatigada que os homens.

Os resultados de vários estudos sobre as diferenças associadas a gênero, na prevalência da fadiga, são apresentados no quadro 3. 
Quadro 3 - Diferenças de gênero na prevalência de fadiga.

\begin{tabular}{|c|c|c|c|}
\hline Autor Principal & $\begin{array}{c}\text { Proporção de Fadiga } \\
\text { em mulheres (\%) }\end{array}$ & $\begin{array}{c}\text { Proporção de } \\
\text { Fadiga em } \\
\text { Homens (\%) }\end{array}$ & $\begin{array}{c}\text { Razão } \\
\text { Mulher/Homem }\end{array}$ \\
\hline Cathebras & 15.2 & 11.2 & 1.4 \\
\hline Chen & 20.4 & 14.3 & 1.4 \\
\hline Hagnell & 31.0 & 21.0 & 1.5 \\
\hline Cox & 29.8 & 18.9 & 1.6 \\
\hline David & 12.0 & 9.0 & 1.3 \\
\hline Garcia and Marks & 29.6 & 29.3 & 1.0 \\
\hline Hammond & 47.5 & 33.0 & 1.4 \\
\hline Ingham and Miller & 27.9 & 16.9 & 1.7 \\
\hline Ingham and Miller & 44.6 & 28.5 & 1.6 \\
\hline Jenkins & 36.7 & 29.3 & 1.3 \\
\hline Kroenke & 28.0 & 19.0 & 1.5 \\
\hline Montgomery & 10.9 & 6.9 & 1.6 \\
\hline Morrison & 16.8 & 6.9 & 2.4 \\
\hline Shepherd & 18.0 & 10.7 & 1.7 \\
\hline Tarnopolsky & 17.1 & 9.8 & 1.7 \\
\hline
\end{tabular}

Fonte: Wessely et al., 1998, p.31.

Os autores chamam a atenção para o fato de que os valores proporcionais listados no quadro 3 são dependentes dos critérios usados e das características das amostras, que diferem marcadamente entre os estudos. Assim, a única comparação possível é a mostrada na terceira coluna da tabela, onde foi calculada a proporção de mulheres afetadas em relação aos homens, em cada estudo separadamente. Não há uma explicação definitiva para esse fato, como apontam Lewis e Wessely (1992).

A questão de determinar a prevalência da fadiga na população esbarra com o problemático conceito de fadiga que é abordado sob vários aspectos nos delineamentos das pesquisas, além disso, não são esclarecidas as condições sociais, políticas e econômicas vivenciadas pelas populações quando da realização das pesquisas. 


\subsection{A Medida da Fadiga}

A medida da fadiga está relacionada à sua dificuldade de definição, pois, como explica Cameron (1973), o método de medida adotado por um pesquisador em particular depende, explicita ou implicitamente, da definição com a qual ele trabalha. Se o fenômeno fadiga é difícil de definir, é compreensivel que haja uma dificuldade na sua mensuração. Em grande parte dos estudos sobre a fadiga, ela tem sido considerada um fenômeno simples, possivel de ser medido quantitativamente. No entanto, a fadiga é um fenômeno complexo, como afirma Cameron (1973):

"... O homem é ambos, adaptativo e decidido em seu comportamento.

Se a demanda das tarefas é alta ele pode responder com grande esforço e se o incentivo para continuar é grande ele pode manter este esforço por um longo periodo. Ele também responde a uma estimulação originada por uma tarefa interessante ou desafiadora. Nos experimentos sobre fadiga ele caracteristicamente responde nesta direção e fazendo assim, ele gera resultados inválidos para propósitos práticos".

Borg (2000) cita que uma das primeiras escalas de fadiga foi a escala de índices de Poffenberger de 7 pontos. Criada em 1928, foi projetada para obter índices de sensações de fadiga de operários. Outros estudos sobre a percepção da fadiga não mediam as variações em intensidade, como os experimentos de classificação progressiva, mas apenas tentavam classificar alguns niveis de intensidade ou pretendiam descrevê-los semanticamente.

Smith (1915-1917) sugere que uma das razões da inadequação dos vários testes de fadiga é que não há garantia de que o individuo mantenha a mesma atitude para com a tarefa durante todo o tempo da investigação. Mesmo que isto aconteça, há ainda a possibilidade de que não existam critérios mínimos para os aspectos que estão sendo medidos, por exemplo, o aborrecimento, a variação no interesse do individuo, a estimulação que ocorre diante da proximidade do fim de uma determinada tarefa, etc. Todos estes aspectos militam contra o sucesso de um teste de medida. 
Cameron (1971) discute que o esforço que pode ser produzido uma ou duas vezes em uma sessão experimental pode não ocorrer novamente e que esse mesmo esforço pode não ocorrer durante os trinta ou quarenta anos de uma vida de trabalho. Deve ser lembrar que puramente sob um critério humanitário não se deve esperar do trabalhador que ele continue realizando o mesmo esforço que é requerido dos indivíduos que participam de um experimento de laboratório.

Chambers (1961) clarifica as dificuldades de se medir a fadiga:

"... É fácil falar sobre fadiga "moderada" ou "excessiva", mas o uso de tais termos denota uma idéia de quantidade de fadiga e quantidade de fadiga é um conceito que tem pouco ou nenhum valor cientifico, uma vez que não é possivel de se medir diretamente".

Muscio (1921a) ao discutir se a medida da fadiga é possivel coloca duas condições que deveriam estar presentes para permitir a quantificação experimental da fadiga:

"... (a) que se saiba o que significa a fadiga e (b) que se tenha algum método, que não o que está sendo sugerido, pelo qual se possa conhecer os diferentes graus de fadiga presentes em diferentes momentos..." (p 31).

O problema começa a partir da primeira condição, onde Muscio questiona que é obviamente absurdo tentar achar um teste para uma entidade indefinida. Para a segunda condição a questão levantada por Muscio é:

"... se não sabemos, depois da aplicação de um método proposto para medir a fadiga, qual o grau de fadiga presente, o resultado obtido da aplicação do método será destituído de significância".

Mayo (1959) cita C.S. Myers ao escrever sobre a medida de fadiga:

"... por mais valiosos que tenham sido os resultados das investigações sobre a fadiga muscular e mental, desenvolvidas em laboratórios, estes têm se revelado totalmente insuficientes em sua aplicação prática, pois as condições de um experimento em laboratório são muito distintas das condições da vida diária. Na fábrica não se pode 
isolar o cansaço muscular, como no laboratório, de certas influências, tais como a habilidade e a inteligência, que dependem do funcionamento correto dos centros superiores do sistema nervoso central..."

Mayo (1959) cita também um questionamento de Cathcart (1928): "... pode-se medir o grau de fadiga? A resposta é negativa, apesar da significativa quantidade de estudos sobre o tema". Como exemplo Cathcart descreve uma investigação realizada em Glasgow (Escócia) que, durante anos, tentou projetar um método fidedigno para medir a fadiga e conclui que até aquele momento não se havia idealizado nenhum método que permitisse avaliar o estado de fadiga de um individuo. Segundo ele: "... com os meios de que dispomos atualmente, é duvidoso que algum dia se possa medir a fadiga". Cathcart continua afirmando que indiretamente o problema tem sido estudado a fundo e pelo menos algumas das deduções a que se tem chegado são indubitavelmente corretas e de grande valia. Alguns dos métodos empregados indiretamente para determinar o grau de fadiga são:

1) variações no rendimento e qualidade do trabalho realizado;

2) tempo perdido;

3) movimento de pessoal;

4) morbidade e mortalidade;

5) acidentes;

6) quantidade do esforço realizado.

Das provas indiretas apresentadas a que provavelmente mereça maior confiança é a que mede o rendimento ou o ritmo de produção (Chambers 1961).

Cameron (1973) conclui, depois de analisar várias investigações sobre a fadiga, que o uso do tempo de recuperação como um índice da fadiga permite a separação de efeitos agudos e crônicos e permite comparar conjuntos amplamente diferentes de condições de trabalho, desde que estas sejam consideradas como sendo diferenciadas, em seus efeitos fatigantes, somente no que se refere aos tempos de recuperação. Desta forma, a medida do tempo de recuperação mostra que fatores de exposição podem 
ser de diferentes naturezas, mas não diferem nos efeitos sobre a recuperação do indivíduo.

Concordando com as dificuldades em medir a fadiga, Grandjean (1988) introduz uma importante constatação: "não existe, hoje, nenhum método direto de avaliação quantitativa do estado de fadiga". Não existe nenhuma medida direta da fadiga, comparável, por exemplo, à medida do consumo de energia em quilocalorias. "Todos os métodos até hoje usados medem determinadas manifestações da fadiga, que só podem ser avaliadas como "indicadores da fadiga".

Para Chalder et al. (1993) a medida da fadiga persiste até hoje como uma dificuldade, exatamente como o foi em 1921 quando Muscio prescreveu que: "o termo fadiga deveria ser absolutamente banido da discussão científica e, conseqüentemente, as tentativas de obter um método para medir a fadiga deveriam ser abandonadas". No entanto, para eles, há uma série de tentativas mais recentes de medir fadiga objetiva e subjetivamente. A fadiga como uma inabilidade objetiva para sustentar uma força pode ser medida eletrofisiologicamente, mas não está necessariamente relacionada à sensação subjetiva de fadiga. Várias tentativas têm sido feitas para produzir escalas que medem ambas: percepção e severidade de fadiga.

Segundo Wessely et al. (1998), a medida da fadiga pode ser realizada através da mensuração de seus componentes. A medida da fadiga como um enfraquecimento de uma função física pode ser estimada através de "autorelato" ou medidas do desempenho físico. Pode ser utilizado como medida, por exemplo, uma ergometria (incluso aqui o instrumental Ergograph de Mosso), o uso de um dinamômetro para medida da força muscular ou uma eletromiografia. O eletromiograma (EMG) fornece informações sobre os efeitos da carga em um único músculo e sobre a cooperação em um conjunto de músculos. Em geral, as pesquisas em laboratório simulam situações de carga de trabalho e condições ambientais (Ortengren, 1975).

A fadiga mental pode ser medida por "auto-relato" ou medidas diretas. As medidas diretas se relacionam ao desempenho cognitivo, tais como, 0 
tempo de reação, a memória, o raciocínio, a vigilância em tarefas e os processos de tomada de decisões (Wessely et al. 1998).

A fadiga como sensação pode ser verificada através do conteúdo do discurso do indivíduo, através de questionários ou entrevistas, com vários itens, ou escalas avaliativas. Nos casos em que medem a fadiga como uma sensação, as pesquisas devem ser classificadas de acordo com o conteúdo (por exemplo, fadiga física ou mental), formato (questionário ou entrevista), número de itens (questionário simples ou múltiplo) métodos com escores, e o período de tempo que ela cobre. Para a medida de um estado de sensação de fadiga Wessely et al. (1998) sugerem a utilização de séries de palavras e conceitos que descrevem esta sensação. Segundo eles, usando um grande número de palavras se produz uma melhor amostragem do conceito.

Como exemplo Chalder et al. (1993) citam a escala de Lee et al. (1991) que inclui 18 descritores em uma Escala Visual Analógica (VAS) e mede sintomas subjetivos de fadiga, incluindo itens relacionados à energia. Citam também a Escala de Fadiga de Piper que mede aspectos multidimensionais da fadiga, como por exemplo, dimensões afetivas, avaliativas e sensoriais. No entanto, sugerem que por causa de sua extensão, esta escala se torna impraticável para o uso rotineiro.

Wessely et al. (1998) apresentam a Escala de Chalder et al. (1993) que compreende sub-escalas separadas em aspectos físicos e mentais. Para esta escala uma lista de 14 itens foi criada por vários especialistas na área para retratar a fadiga física e mental. Sintomas não relacionados especificamente à fadiga, mas associados com a Síndrome da Fadiga Crônica não foram incluídos, pois a intenção foi produzir uma escala que medisse especificamente a fadiga generalizada.

Yoshitake (1971), citando Bartley e Chute, acredita que na investigação da fadiga de trabalhadores na indústria três fatores devem ser levados em consideração: (1) desempenho, (2) mudanças na função psicológica e fisiológica no curso do trabalho e (3) a sensação subjetiva de 
fadiga experenciada pelo trabalhador. $\mathrm{O}$ autor discute que, apesar da sensação subjetiva de fadiga ter sido considerada por Bartley e Chute como um fator a ser pesquisado, este item geralmente aparece nas pesquisas meramente como uma questão adicional da investigação. Um inquérito cuidadoso sobre os fatores subjetivos da fadiga é essencial porque a fadiga industrial é considerada como a expressão de atitudes, orientações e adaptações do trabalhador. Segundo o autor, a sensação de fadiga consiste de diferentes dimensões como desconforto, aversão ao trabalho, desejo de descanso, impaciência e sentimentos de incongruência física, mental e neuro-sensorial. Em resumo, o autor acredita que a sensação de fadiga é, sobretudo, um desconforto experenciado pelo trabalhador.

Wessely et al. (1998) listam as principais medidas da fadiga, de acordo com o componente que está sendo medido. Quando o interesse é nos mecanismos internos, em uma abordagem bioquímica pode-se medir a quantidade de plasma cortisol; se for fisiológica, analisa-se o trabalho muscular e, dentro de uma abordagem psicológica, pode-se medir a freqüência visual crítica de fusão. Nas abordagens relacionadas aos processos fisiológicos e bioquímicos podem ser realizados estudos neurofisiológicos da estimulação do músculo e medidas polissonográficas do sono. As medidas associadas ao contexto de ocorrência da fadiga podem ser realizadas através de comparações "entre-culturas" (medidas culturais); entrevistas sobre eventos recentes na vida dos indivíduos (medidas sociais); medida de fatores ambientais, tais como temperatura e ruído (fatores físicos) e demandas do trabalho (avaliação da tarefa).

Algumas pesquisas no campo da fadiga são voltadas para a experimentação ou validação de instrumentos que tornem possíveis a sua mensuração. Este é o caso das pesquisas realizadas por Åhsberg e Gamberale (1998) e Ånsberg et al. (2000), que objetivavam a validação do instrumento SOFI (Swedish Occupational Fatigue Inventory: Inventário de Fadiga Ocupacional Sueco). O SOFI consiste de 25 expressões que representam cinco fatores: falta de energia, força física exercida, desconforto 
físico, falta de motivação e sonolência, investigados antes e depois da realização de um trabalho físico. A pesquisa de validação foi realizada com uma amostra de 20 homens e 20 mulheres que responderam o questionário após a realização de um trabalho com exigência física e após um trabalho com exigência mental. Os resultados encontrados após o trabalho físico mostraram que a falta de motivação e sonolência parecem não ter relação com a carga física e que esforço físico, desconforto físico e, até certo ponto, a falta de energia, foram afetados pelo trabalho dinâmico em grandes grupos musculares e a carga estática em pequenos grupos musculares. No caso do trabalho com exigência mental, os resultados mostraram que as dimensões mais afetadas foram a falta de energia, falta de motivação e sonolência enquanto que as dimensões esforço físico e desconforto físico não mostraram ser importantes. A relação estatisticamente significante entre os três fatores (desconforto físico, esforço físico e falta de energia) e a questão implícita da fadiga indica, segundo os autores, que o SOFI mede a fadiga assim como percebida pelo trabalhador.

\subsection{A Fadiga e o Trabalho}

\subsubsection{Determinação do Processo Saúde/Doença no Trabalho e a Fadiga}

Do ponto de vista dialético histórico Marx (1987), ao escrever O Capital em 1867, define o trabalho como o uso da força de trabalho. Este conceitua que "... o trabalho é, antes de tudo, um processo de que participam o homem e a natureza, processo em que o ser humano com sua própria ação impulsiona, regula e controla seu intercambio material com a natureza". Ao mesmo tempo em que o homem modifica a natureza exterior também modifica sua própria natureza. Marx define que o processo de trabalho se decompõe nos seguintes elementos: (1) a atividade adequada a um fim, isto é o trabalho propriamente dito; (2) a matéria que se aplica ao trabalho, ou seja, objeto sobre o qual o trabalho atua e (3) os meios de 
trabalho, o instrumental de trabalho. O meio de trabalho e o objeto de trabalho constituem os meios de produção. Bicalho (sd), em seu resumo literal do Capital, escreve que as características do modo de produção capitalista, onde o processo de trabalho é considerado como consumo da força de trabalho, apresenta dois fenômenos particulares. $O$ primeiro diz respeito ao controle do trabalhador e o segundo está relacionado ao produto do trabalho, que é propriedade do captilalista.

No sentido etimológico a palavra trabalho, na língua portuguesa, tem raízes na palavra latina "tripaliare", que significa torturar com o "tripalium" (instrumento de tortura). Carrega, portanto um sentido de penalidade e sofrimento (Fialho 1995).

Esta atividade do homem, ou o trabalho propriamente dito, pode ter este sentido de pena, sofrimento. Na tradição judaico-cristã, como pode ser observado na Bíblia, no capitulo do Gênesis 3/19: "...ganharás o pão com o suor do seu rosto", o trabalho está associado ao castigo do pecado original. Segundo Wisner (1987) "o que não é penoso não é trabalho, aos olhos de alguns". Este trabalho com um caráter penoso, que supõe um sofrimento, tem se transformado através dos séculos, tanto na sua execução como em sua tecnologia. As transformações que ocorrem no trabalho podem tanto aumentar a carga de trabalho como aliviar e até eliminar cargas que não deveriam existir.

A utilização de diferentes recursos tecnológicos com diversificadas formas de controle e organização tem, como conseqüência, à exposição dos trabalhadores a também diferentes modalidades e intensidades de riscos ou cargas de trabalho, estes intermediados pelas particularidades dos diversos processos industriais (Queiroz e Maciel 2001). Nesta transformação do trabalho ocorrem estágios de produção que permanecem fiéis a processos tecnológicos do início do século, como por exemplo, o caso do consumo de peças decorativas de vidro que ainda são fabricadas por processo exclusivamente manual (Queiroz 1998). As cargas de trabalho podem ser de diferentes naturezas, dependendo do processo produtivo empregado, por 
exemplo, a exposição a ruído e calor em indústrias vidreiras e têxteis. Esta carga de trabalho também pode estar relacionada ao modo como o trabalho é realizado e ligado à forma como o trabalho está organizado (Queiroz 1998).

Segundo Maciel (1995) as mudanças nos padrões de produção com a introdução da informatização e automatização trazem como resultado final uma atividade altamente repetitiva e monótona, onde o trabalhador realiza seu trabalho em um ritmo relativamente elevado. Estes fatores estão, por sua vez, presentes em diversos tipos de processos produtivos, independente da especificidade do ramo industrial, dos serviços, da agricultura, etc, e podem determinar a penosidade real do trabalho.

Muitos dos estudos sobre a fadiga relacionam determinados fatores das condições de trabalho com o seu aparecimento, por exemplo, permanecer longas horas na direção, trabalhos noturnos, jornada de trabalho extensa ou sem pausas para descanso, trabalho com exigência de esforço mental elou físico, trabalho em condições ambientais desconfortáveis sob ruído, calor (Ahsberg e Gamberale 1998; Ahsberg et al. 2000; Metzner 1999; Askerstedt e Landstrom 1998; Milosevic 1997; KristalBoneth 1996; Kjellberg e Skoldstron 1996; Grandjean 1988; Welch et al. 1971 e Crawford 1961).

O reconhecimento da fadiga relacionada ao trabalho no Brasil pode ser demonstrado através da Consolidação das Leis do Trabalho - CLT Decreto lei $n^{\circ} 5.452$, de $1^{\circ}$. -5- 1943 (Brasil 2000) e das Normas Técnicas do Ministério da Saúde (2001).

$\mathrm{Na} \mathrm{CLT}$ ( Brasil 2000) a referência a fadiga é feita no Capítulo V, Da Segurança e da Medicina do Trabalho, Seção XIV - da Prevenção da Fadiga. Esta prevenção é indicada nos artigos 198/199 e no parágrafo único. A prevenção à fadiga é entendida como o limite para remoção de peso que um empregado pode remover individualmente (indicado como o máximo de 60 quilogramas) e como a colocação de assentos que assegurem uma postura correta evitando posições incomodas ou forçada quando o trabalho 
é realizado na postura sentada e assentos colocados a disposição para que o trabalhador se sente quando o trabalho é realizado na postura em pé.

Nas Normas Técnicas do Ministério da Saúde (2001) a fadiga é reconhecida como Neurastenia - F48.0, utilizando a CID 10 e assim definida:

"... a característica mais marcante da síndrome de fadiga relacionada ao trabalho é a presença de fadiga constante, acumulada ao longo de meses ou anos em situações de trabalho em que não há oportunidade de se obter descanso necessário e suficiente. A fadiga é referida pelo paciente como sendo constante, como acordar cansado, simultaneamente física e mentalmente, caracterizando uma fadiga geral. Outras manifestações importantes são: a má qualidade do sono, dificuldade de aprofundar o sono, despertares freqüentes durante a noite, especificamente insônia inicia, dificuldade para adormecer ou ä cabeça não consegue desligar", irritabilidade ou falta de paciência e desânimo. Outros sintomas que podem fazer parte da síndrome são: dores de cabeça, dores musculares (geralmente nos músculos mais utilizados no trabalho), perda do apetite e mal estar geral. Trata-se em geral de um quadro crônico".

Os fatores que podem atuar como associados à determinação da fadiga englobam o ritmo de trabalho acelerado, sem pausas ou com pausas insuficientes e sem as devidas condições para repousar e relaxar, jornadas de trabalho prolongadas (excesso de horas extras, tempo de transporte muito longo, dupla jornada de trabalho), jornada de trabalho em turnos alternados. Agentes quimicos presentes no ambiente de trabalho também podem estar associados ao adoecimento por fadiga tais como brometo de metila, chumbo, manganês, mercúrio e seus respectivos compostos, sulfeto de carbono, tolueno e outros solventes neurotóxicos, tricloroetileno, tetracloroetileno, tricloroetano e solventes orgânicos halogenados neurotóxicos.

Para o reconhecimento da relação entre a fadiga e o trabalho a norma define que o trabalho desempenha o papel de causa necessária. 


\subsubsection{As Pesquisas de Fadiga e o Trabalho}

A fadiga industrial, segundo Wisner (1987), é um fenômeno maciço na experiência vivida pelos trabalhadores. Wisner relata, enquanto experiência, que o fenômeno fadiga se expressa logo que conversamos com a maior parte dos trabalhadores. Certos aspectos da fadiga são claramente identificados com o sofrimento e o desinteresse, mas este aspecto está longe de ser o único. Os fisiologistas e psicólogos do trabalho mostraram uma degradação das capacidades, recuperáveis após um tempo mais ou menos longo no qual a intensidade, bem como a duração do trabalho, têm um papel considerável. As diversas caracteristicas do ambiente físico e químico podem não agir de maneira direta sobre a atividade física ou de trabalho, mas tornar a situação de trabalho fatigante, incômoda. Essas conseqüências estão fortemente ligadas à própria natureza do trabalho, fonte geradora de fadiga, sofrimento e incômodo. Wisner (1989) entende que a fadiga industrial ocorre freqüentemente nos trabalhadores, refletindo as demandas do trabalho e os efeitos da exposição a riscos físicos e químicos. Segundo ele, algum grau de fadiga tem sido reconhecido como uma conseqüência inevitável do trabalho, especialmente de trabalhos que demandam um esforço muscular pesado. A fadiga no trabalho também é considerada por Beurskens (2000) como uma experiência normal e diária.

Um estudo clássico na área de trabalho e fadiga é o estudo de Le Guillant et al. publicado em 1956, traduzido por Monetti e Ferreira (1984), sobre a neurose das telefonistas. Os autores relatam que as alterações observadas nas telefonistas e mecanografistas francesas parecem fazer parte de uma "sindrome geral de fadiga nervosa". Trata-se de uma "sindrome subjetiva comum" de fadiga nervosa que se mostra presente em telefonistas (em $33 \%$ dos casos) em graus diversos, é uma impressão de lassidão profunda, de verdadeiro "aniquilamento" no fim da jornada de trabalho. As telefonistas se queixam de que $\circ$ trabalho intelectual é impossivel, pois quase todas apresentam queixas significativas relacionadas às suas faculdades intelectuais. Ocorrem alterações de humor e de caráter e 
as telefonistas apresentam verdadeiras crises de nervos, mantido pelo próprio trabalho. Algumas telefonistas que apresentam a sindrome atingem rendimentos consideráveis (140 a 150\% em relação à média). Estes rendimentos são alcançados não por excesso de empenho, mas porque o próprio trabalho, dizem elas, as irrita e "quanto mais se irritam, mais se apressam". Também apresentam distúrbios de sono, hipersonia diurna, insônia noturna, sono agitado (pouco repousante), insônia quase total, alterações somáticas, angústias, palpitações, dores pré-cordiais, sensações de opressão torácicas, "bolas no estômago", anorexia e alterações menstruais. Os autores acreditam que a sindrome não é exclusiva das telefonistas e ocorre em outras funções exigentes, com ou sem fadiga muscular, um ritmo excessivamente rápido de operações e propiciam condições de trabalho objetiva ou subjetivamente penosas: mecanização dos atos e monotonia e vigilância rígida.

Milosevic (1997) conduziu uma pesquisa sobre fadiga em motoristas de caminhões. Para a pesquisa foi utilizado um questionário, aplicado em uma amostra de 307 motoristas, que continha informações sobre sinais de fadiga, situações em que a fadiga aparece e outros fatores que contribuem para fadiga nos motoristas. Os resultados mostraram que após 7 horas na direção, considerado um tempo prolongado, os motoristas apresentam mudanças nos limiares auditivos de sensibilidade, mudanças na temperatura, na pressão sangüinea diastólica, na acomodação visual e no tempo de reação visual. Os motoristas apresentaram, especialmente, mudanças na fadiga subjetiva, medida através de uma escala de estados subjetivos. Os resultados também indicaram que a dor lombar foi o sinal de fadiga mais apontado nas respostas dos motoristas.

Matsuda et al. (1997) desenvolveram uma pesquisa para estudar a fadiga subjetiva entre trabalhadores de indústrias vietnamitas com a recente importação de tecnologia. O estudo foi realizado em dez indústrias da cidade de Hochimim e Hanói. Em cada fábrica um grupo de trabalhadores da mesma oficina e com um mesmo tempo de trabalho (aproximadamente 40 
trabalhadores) foi escolhido de forma não aleatória. Aos trabalhadores foi solicitado o preenchimento de dois questionários. O primeiro questionário continha perguntas relacionados aos dados pessoais e impressões sobre as condições de trabalho. O segundo questionário versava sobre queixas subjetivas de fadiga. Este último foi desenvolvido pela Associação Japonesa de Saúde Industrial e é composto de 30 questões divididas em 3 categorias: os primeiros 10 itens se relacionam a sonolência e lentidão, os 10 itens seguintes a dificuldades de concentração e os últimos 10 itens a projeções da desintegração física, ou seja, a projeção da fadiga em alguma parte do corpo. O questionário foi entregue aos trabalhadores antes e depois do trabalho e os itens foram preenchidos no local de trabalho. Os resultados mostraram que, no conjunto, a taxa de prevalência das queixas de fadiga aumentou após o trabalho em todas as categorias. As taxas de queixas de fadiga foram muito altas entre os trabalhadores das indústrias em que 0 trabalho era intenso, tais como as têxteis e eletrônicas. Uma análise de regressão múltipla mostrou os seguintes fatores determinantes para a fadiga nos ambientes de trabalho que levaram às mais altas queixas de fadiga: exposição a poeiras, exposição a ruído, exposição a calor e insatisfação com as condições de trabalho. Os resultados sugeriram que a inadequação ergonômica da linha de montagem de uma das indústrias foi a principal causa das altas taxas de queixa de fadiga subjetiva entre os trabalhadores. Sobre a questão dos fatores determinantes, Putz-Anderson (1993) indica que a fadiga que aparece durante o trabalho depende dos requerimentos das tarefas e da duração destas. Porém, quando parâmetros físicos do trabalho não podem ser modificados, a redução da fadiga pode ser realizada somente por diminuição da duração do ciclo de trabalho.

Em outro estudo sobre fadiga entre trabalhadores de indústrias israelitas (Kristal-Boneh et al. 1996), foram examinadas as condições ocupacionais e de saúde relacionadas a hábitos em uma amostra grande de trabalhadores em seis setores industriais, com 0 intuito de definir as condições de trabalho que deveriam ser modificadas. Foi analisada uma 
amostra total de 3.785 indivíduos, através da aplicação de um questionário com perguntas simples sobre a sensação de fadiga dos trabalhadores, durante e após o trabalho. $O$ questionário versava sobre a atividade física fora do trabalho, as condições de trabalho (categoria de trabalho, carga física, sistema de controle de temperatura, ruído e monotonia). A avaliação da fadiga foi baseada em questões únicas sobre a frequência e severidade de sintomas (em uma escala de quatro níveis). Os autores consideraram a sensação de fadiga significativamente presente quando os sintomas foram experenciados frequentemente ou muito frequentemente. Não foi possivel para os autores diferenciar os vários tipos de fadiga (por exemplo, física ou mental). Os pesquisadores indicaram que um dos principais resultados do estudo foi que as queixas de fadiga são comuns entre trabalhadores industriais e que existem fatores das condições de trabalho associados aos sintomas. Os autores foram capazes de identificar duas variáveis que influenciam a prevalência da fadiga independentemente: a atividade esportiva e o sistema de controle da temperatura no local de trabalho. Quando a temperatura do local de trabalho não é controlada, há um aumento de $50 \%$ na prevalência da fadiga (resultado da análise multivariada). Houve diferença na prevalência de queixas de fadiga entre as várias indústrias. Essas diferenças foram explicadas inteiramente por diferenças na proporção de trabalhadores expostos ao trabalho monótono, a altas cargas físicas de trabalho e na falta de controle da temperatura.

A intensidade elevada de ruído no ambiente de trabalho atuando como um aspecto no surgimento da fadiga foi estudado por Kjellberg e Sköldström (1996) em mecânicos de avião. Os trabalhadores analisados realizavam o mesmo tipo de tarefas em dois ambientes diferentes: na pista de pouso/decolagem e no "hangar" de reparos de aviōes. As tarefas eram realizadas nestes locais em semanas alternadas. Na semana de trabalho na pista de pouso/decolagem os trabalhadores estavam expostos a intensidades elevadas de ruido e na semana de trabalho nos hangares o ruído era de baixa intensidade. Os autores utilizaram a medida do tempo de 
reação simples da tarefa como uma medida da fadiga (Gamberale et al. 1990; citado em Kjellberg e Sköldström 1996) e foi aplicado um checklist antes e após cada dia de trabalho. O nível de ruído foi medido nas duas situações de trabalho. Os resultados mostrados na pesquisa confirmaram que os mecânicos se sentiram mais sonolentos e com menos energia após o trabalho durante a semana de trabalho na pista de pouso/decolagem do que na semana em que trabalharam nos hangares de reparo. Estes efeitos foram aumentando durante a semana, observando-se um efeito cumulativo na fadiga durante a semana na pista de pouso/decolagem. Souza et al. (2002) desenvolveram um estudo visando examinar a prevalência da fadiga crônica entre trabalhadores bancários no Brasil e as possiveis associações com gênero e condições de trabalho. Foi estudada uma população de 735 trabalhadores do departamento de processamento de dados de um banco estatal na cidade de São Paulo. A prevalência estimada de fadiga crônica foi de $8,7 \%$, com $7,8 \%$ entre homens e $11,0 \%$ entre as mulheres. De acordo com os dados do estudo, a fadiga crônica é comum entre trabalhadores bancários. A alta prevalência foi associada com monotonia, repetitividade, ritmo acelerado de trabalho, insatisfação no trabalho e a carga de trabalho doméstico. As situações de fadiga no trabalho são citadas mesmo quando é analisada uma situação de acidente ou incidente, onde a fadiga não é o objeto em estudo. Esta situação pode ser exemplificada no estudo desenvolvido por Llory (1999) que analisa o custo do silêncio dos trabalhadores em acidentes industriais. Quando Llory propõe uma análise do acidente nuclear ocorrido em Chernobyl, ele aponta para um aspecto concorrente para o acidente: qual era o estado de fadiga dos operadores?

\subsection{Compreendendo o Conceito de Fadiga}

A revisão dos estudos sobre fadiga desenvolvidos a partir de Beard em 1869, passando pelos estudos de Mosso (1896), Muscio (1921), Smith (1915-1917), Mayo (1946), Bartley e Chute (1947), Welford (1953), Cameron 
(1971, 1973), Grandjean (1979,1988), Wessely et al. (1998), Asberg (2000), dentre outros, mostra uma preocupação comum, presente na maioria dos autores, sobre a dificuldade em definir e mensurar a fadiga, apesar de a fadiga ser comum na população.

A fadiga é experenciada por muitas pessoas, mas complexa e gerada pela influência de vários fatores, portanto multifatorial. A fadiga é um estado com aspectos tanto da esfera fisiológica como da psicológica. Os estudos da fadiga muscular mostram que só a fadiga registrada em um músculo não justificaria o estado geral de cansaço apresentado pelos indivíduos que se dizem fatigados. Depois de haver passado por várias tendências, entre elas uma definição ancorada em rendimentos de produção; pela consideração de a fadiga ser uma forma de conflito, que ocorre entre as demandas das situações de tarefas versus a aversão do indivíduo ao esforço, a fadiga mais modernamente tem sido entendida em termos de reações individuais ao estresse sobre um período de tempo e de que no estado de fadiga fica a sensação subjetiva de cansaço e esta sensação é acompanhada de repugnância freqüentemente registrada como de natureza emocional.

Apesar das dificuldades de definição, os pesquisadores não delegaram a um segundo plano a questão de a fadiga ter fatores determinantes diversos, mas suas afirmações vêm ressaltar que a questão individual, subjetiva, deve ser considerada, pois é um fator importante e presente quando se estuda a fadiga. O que a história dos estudos da fadiga parece indicar é que, a princípio, os estudos não atentavam para as reações individuais como um aspecto relevante para o seu estudo e estas foram se sobressaindo nas linhas de pesquisas no decorrer do tempo. Mas as condições e achados de pesquisas não deram substancial clareza para que se chegasse a uma definição do fenômeno. O que é visível é que a fadiga, seja este nome ou outro qualquer, é um estado funcional presente nos seres humanos, comumente encontrado. Quando dizemos que seja esse o nome ou qualquer outro, corroboramos a idéia de Cameron (1973) quando reflete que abandonar o termo "fadiga" não a torna uma situação inexistente. $O$ 
problema não está no nome, mas na condição em si e sua complexidade, dificultando uma definição.

Mesmo com as dificuldades percebidas para delimitar o fenômeno e enfim defini-lo consensualmente, percebemos que os vários autores definem a fadiga de acordo com seus propósitos pessoais, mas com conceitos comuns em várias pesquisas. Observamos termos similares, ou sinônimos, para esta definição. Assim fadiga tem sua definição com base em parâmetros observáveis para variações no esforço muscular, ou aversão a este, variações no esforço mental e na diminuição do desempenho quando da realização de uma atividade. A fadiga é conceituada por vários autores como um estado em que ocorre uma sensaçăo difusa de cansaço que é acompanhada de uma indolência e falta de motivação para qualquer atividade, presença de sono ou sonolência, decréscimo no desempenho e sensação subjetiva de cansaço, sensação subjetiva de lassidão e uma resposta generalizada ao estresse ao longo do tempo.

Há também um esforço em entender a fadiga através de sua classificação em componentes mensuráveis. Este é o caso da proposta de Bartley e Chute (1947) e Wessely et al. (1998) de dividi-la em componentes. A nosso ver, a divisão em componentes não leva a uma definição de fadiga nem é uma tentativa nessa direção, mas sim uma proposição do que pode estar ocorrendo quando o indivíduo se encontra no estado de fadiga.

Nos instrumentos de medida da fadiga, de uma forma geral, as variáveis de estudo se referem a termos semelhantes para pesquisar a fadiga nos indivíduos, como por exemplo, os instrumentos utilizados por Chalder et al. (1993), Yoshitake (1971) e Ahsberg et al. (2000) na pesquisa da percepção de fadiga. Em Chalder et al. (1993) as variáveis se referem a sintomas físicos, tais como cansaço, sono ou sonolência, falta de energia, fraqueza em músculos, e mentais, tais como dificuldade de concentração, de memorização, etc; em Matsuda et al. (1997) as variáveis estão relacionadas à lentidão e sonolência, à dificuldade de concentração e à projeção da desintegridade física e em Ånsberg e Gamberale (1998) e Âhsberg et al. 
(2000), as variáveis contidas no questionário são sobre falta de energia, falta de motivação, esforço físico, desconforto físico e sonolência. Podemos então observar que a sensação de fadiga pesquisada por estes estudiosos se refere a termos comuns tanto na abordagem dos aspectos físicos quanto nos aspectos mentais.

Os instrumentos utilizados na medida da fadiga carregam a idéia de que um problema importante na definição da fadiga é seu entendimento a partir de sinais e sintomas para assim definir e investigar o fenômeno. Fadiga é uma falta de energia, uma presença de sonolência, uma falta de motivação, um cansaço, uma falta de descanso, sensações demonstradas pelo indivíduo, ou seja, um sinal externo de um estado interno mal definido. O sintoma é a referência. Então, sentir cansaço, sentir sono ou sonolência, ter dificuldade de concentração, sentir os sintomas e sinais a mais de 6 meses é o parâmetro possivel de medida da fadiga. A entidade é de difícil definição, mas a fadiga é um fenômeno presente e vivenciado pelas pessoas portadoras destes sintomas e sinais. Porque não procurar a compreensão do fenômeno através destes sinais e sintomas? Porque as pessoas têm estes determinados sinais e sintomas? Acreditamos que este é o momento atual dos estudos sobre a fadiga, ou seja, a constatação de que existe uma sensação subjetiva caracterizada pela expressão de sinais e sintomas. As pesquisas que lidam com o fenômeno "fadiga" têm se desenvolvido em relação a estes indicadores.

A complexidade do fenômeno fadiga pode ser notada na própria CID $10^{a}$ revisão (OMS), pois a fadiga aparece classificada em 3 momentos: como transtorno mental, como fatores que influenciam o estado de saúde do individuo e como sinais e sintomas mal definidos. No quadro de transtornos mentais a Neurastenia (Fadiga), é interpretada como uma síndrome com definições calcadas em vários sinais e sintomas. Na classificação de sinais e sintomas gerais o "mal estar, fadiga", pode ser considerado como sinônimo de cansaço, debilidade, astenia ou deterioração física geral, mas não é apresentada com característica sindrômica. Aqui o cansaço pode estar 
sendo gerado por várias causas não expressas na CID. Nos sinais gerais, não existe uma definição como na neurastenia e nos transtornos mentais. $A$ classificação de estafa segue a mesma tendência de sinais gerais e sintomas, sem definição precisa. Nesse caso, a estafa está sendo vista como fadiga, pois se trata de uma "exaustão das energias vitais". Pode ser notado que em todas estas classificações a fadiga não é a palavra determinadora da classificação, ou seja, vem antes definida por outra palavra: mal estar, neurastenia e estafa. Este fato pode ser entendido como uma dificuldade real em usar a palavra fadiga na classificação do fenômeno.

Por outro lado uma questão que pode estar dificultando a definição de fadiga é a confusão existente entre as características da fadiga e a caracterização do objeto, ou seja, a fadiga em si. Discutir as causas é teorizar sobre a determinação e definir o que é fadiga está no campo do estudo do objeto. O que ocorre nos estudos sobre fadiga é uma confusão entre esses dois campos. Como o objeto tem sido de difícil definição, então fadiga passa a ser definida a partir das causas ou a partir dos efeitos como, por exemplo, os sinais e sintomas.

Do ponto de vista do objeto "fadiga" dois aspectos dos estudos em saúde deveriam ser abordados para se entender a fadiga: a abordagem clinica (das expressões) e a abordagem patológica (das alterações). A abordagem da clínica remete a expressões que têm sido usadas e acima descritas: os sinais e sintomas. A abordagem da patologia englobaria 0 conceito de normal e patológico averiguando as alterações anatômicas, patológicas, bioquímicas e genéticas fora de padrões estabelecidos por métodos estatísticos. Aqui ocorre o problema da mensuração de um objeto para o qual é difícil definir o normal e o patológico. Não é como o caso de uma anemia, por exemplo. A anemia pode ser conceituada de uma forma geral quando o indivíduo apresenta uma diminuição do número ou conteúdo de hemoglobina das hemácias devido à perda de sangue, produção prejudicada ou destruição das hemácias. É necessária a definição de seu mecanismo fisiopatológico para a compreensão de sua natureza essencial e 
para planejamento do tratamento apropriado. Esse mecanismo fisiopatológico é conhecido na anemia. Para se definir que um indivíduo apresenta anemia se procede à contagem, uma delimitação numérica, de hemácias no sangue, pois existe um valor normal para os individuos, ou seja, um intervalo numérico dentro do qual o número de hemácias caracteriza a normalidade.

As pesquisas que têm tentado demonstrar uma alteração fisiológica concreta são as pesquisas sobre a fadiga muscular. As teorias sobre o acúmulo do acido lático conjugado com alterações na nutrição do tecido muscular centradas no nivel do fluxo sanguíneo para o músculo, no desequilibrio entre demanda e oferta de energia para a ação muscular, etc. Para a fadiga generalizada os estudos partem dos sintomas subjetivos. Grandjean (1988) propõe uma conceituação com bases neurofisiológicas de explicação da fadiga procurando ligar alterações que ocorrem ao nível do cérebro com o estabelecimento da fadiga. Os estímulos que aceleram ou inibern o sistema de ativação reticular e o sistema límbico podem gerar um estado funcional que leva a sintomas inclusos no quadro de fadiga. 0 sistema de ativação reticular está relacionado ao ciclo sono/vigília e o sistema límbico às emoções. Grandjean considera a fadiga como um estado emocional.

Para definir fadiga crônica é necessário que o clínico tenha descartado diagnósticos diferenciais de um grande número de distúrbios tanto físicos como psiquiátricos. Mas a questão de definir a fadiga crônica nos parece uma tarefa menos árdua, mais fácil do que definir fadiga, uma vez que a fadiga crônica tem um tempo delimitado de fadiga persistente por mais de 6 meses. Assim, a fadiga crônica já parte da condição de existência de um quadro de fadiga. Quando relacionada a doenças pré-existentes a pesquisa do fator determinante pode ser uma meta atingivel porque o diagnóstico é diferencial, afastando todos os diagnósticos de doenças bem definidas. 


\section{OBJETIVOS E HIPÓTESE}

A pesquisa aqui proposta pretende contribuir para a compreensão de como o fenômeno fadiga é sentido pelos trabalhadores. Assim, pretende-se estudar a sensação de fadiga. Por outro lado, pretende-se verificar até que ponto os questionários ou escalas, considerados medidas objetivas da fadiga, se relacionam à sensação relatada pelos trabalhadores e como se dá essa relação. Na verdade, quando da aplicação de um questionário, não se sabe verdadeiramente qual o entendimento do trabalhador sobre o termo ou conceito utilizado, diminuindo, portanto, a significância do estudo. A investigação do que os trabalhadores pensam que é a fadiga, como eles sentem o seu cansaço, o seu estado interno, parece ser um primeiro passo para identificar a validade das escalas aplicadas na avaliação subjetiva da fadiga.

A fadiga é um caso em que as medidas objetivas não têm sido muito frutíferas, até porque, normalmente, são mal definidas. Grandes conceitos em fase de evolução, como é o caso do conceito da fadiga, merecem uma abordagem subjetiva, no sentido de explorar melhor o fenômeno, pois a indefinição conceitual atua como um entrave nas pesquisas que têm tentado estudá-la.

Do ponto de vista prático, é importante conhecer o fenômeno fadiga, pois essa compreensão pode subsidiar a pesquisa sobre condições de trabalho e fadiga e contribuir para o desenvolvimento de possiveis intervenções visando a saúde no trabalho. 
Os objetivos principais do estudo são:

Analisar a presença do estado de sensação de fadiga generalizada em uma amostra da população trabalhadora em uma indústria gráfica da região metropolitana de São Paulo, utilizando dois instrumentos: um quantitativo e outro qualitativo. A partir dessa avaliação, bem como de uma investigação das condições de trabalho desses indivíduos, pretende-se fazer uma comparação dos resultados obtidos com os dois instrumentos, analisando suas validades e, ao mesmo tempo, avaliando a validade do conceito de fadiga como um termo aglutinador e explicativo de fenômenos que ocorrem nos trabalhadores decorrentes das suas atividades.

\section{Os objetivos especificos são:}

- Identificar a ocorrência de sensação de fadiga através da aplicação dos referidos instrumentos na população gráfica estudada.

- Verificar os fatores determinantes presentes no trabalho da população estudada, que podem dar origem a estados de fadiga.

- Comparar os resultados obtidos através dos dois instrumentos.

\section{HIPÓTESE}

A hipótese principal do trabalho é que a sensação de fadiga, quando medida quantitativamente e esta sensação, enquanto coletada por um método qualitativo, são dois fenômenos diferentes. 


\section{MÉTODO}

A pesquisa foi realizada com trabalhadores de uma indústria gráfica da cidade de São Paulo. A indústria pesquisada foi escolhida a partir de critérios relacionados ao número de trabalhadores nas funçōes analisadas e acessibilidade para a realização da pesquisa. As etapas metodológicas são descritas a seguir.

\subsection{Conhecimento do Processo e das Condições de Trabalho}

Foi realizada uma investigação, não exaustiva, sobre o trabalho e as condições de trabalho nos setores selecionados. Essa investigação teve por objetivo identificar os possíveis fatores associados a determinação da fadiga relacionados ao trabalho e como o trabalho pode sobrecarregar o individuo que o realiza. Para tal, foi utilizada a observação livre do posto de trabalho, focalizando-se aspectos físicos e organizacionais das condições de trabalho, como proposto por vários métodos ergonômicos, incluindo o de Wisner (1987). A proposta da ergonomia contempla o estudo da adaptação do trabalho ao ser humano, entendendo o trabalho de forma ampla, onde se engloba o estudo de toda a situação em que ocorre o relacionamento entre o ser humano e o trabalho (lida 1992, Wisner 1994). O estudo dessa adaptação deve conter a investigação da relação dos aspectos do trabalho com o conforto e bem estar do trabalhador.

Os postos de trabalho escolhidos para as observações estavam no Setor de Acabamento das revistas e no Setor de Telemarketing Ativo.

A eleição dos trabalhos a serem observados se deu pela acessibilidade para a observação e foram designados pela empresa e pelo conhecimento prévio da pesquisadora de que estes eram trabalhos que apresentavam fatores que poderiam expor o trabalhador ao adoecimento, como demonstrado em trabalhos de análise das condiçōes de trabalho realizados pela empresa. 
As observações no Setor de Telemarketing Ativo ocorreram durante três períodos no turno matutino e as observações no Setor de Acabamento ocorreram durante dois períodos, também no turno matutino, sendo que um dos períodos foi observado no dia de sábado, quando ocorre sobrecarga de trabalho, pois a revista de maior tiragem da empresa é acabada neste dia.

\subsection{Avaliação da Sensação de Fadiga Através de um Questionário}

\subsubsection{Seleção dos Trabalhadores}

Neste trabalho as amostras foram selecionadas por conveniência e não se trata de amostras representativas e foram compostas por trabalhadores do setor de Telemarketing Ativo e do Setor de Acabamento da indústria gráfica estudada.

A aceitação da empresa em permitir que realizássemos a pesquisa foi importante, pois tivemos acesso a um campo de trabalho na tentativa de embasar a discussão sobre o conceito de fadiga, mas o aspecto logístico que a empresa desenhou para permitir 0 andamento da pesquisa foi dificultado no que diz respeito ao tempo disponibilizado pela empresa para a realização da pesquisa (aplicação de questionários e entrevista com os trabalhadores). A alegação da empresa foi de que existia um problema com a produção em relação ao número de revistas produzidas pela máquina e o número de trabalhadores, ou seja, cada trabalhador tem sua tarefa determinada e a saída de um ou dois trabalhador(es) para responder ao questionário poderia comprometer a qualidade da produção ou até mesmo sobrecarregar o(s) trabalhador(es) que ficariam no posto. Portanto, a definição do grupo de trabalhadores para estudo ficou submetida à sugestão do setor disponibilizado pela empresa, tanto em relação ao questionário quanto às entrevistas. Esta situação foi equacionada de forma coerente e acreditamos não ter havido prejuízo para a qualidade do trabalho. Assim, o grupo de trabalhadores foi composto por 160 trabalhadores no Setor de Acabamento de revistas e 40 trabalhadores no Setor de Telemarketing Ativo. 
No nosso entender, a definição da empresa quanto aos setores a serem trabalhados nesta pesquisa não foi problemática, uma vez que nos setores escolhidos a representação dos trabalhadores foi de $100 \%$ no Setor Telemarketing Ativo e de $32 \%$ no Setor de Acabamento, pois neste setor trabalham aproximadamente 500 trabalhadores divididos em 3 turnos de trabalho. Os turnos estudados nos dois setores foram os turnos matutino e vespertino. O turno noturno só existe no Setor de Acabamento de revistas e este não foi disponibilizado para este estudo.

A participação nas entrevistas qualitativas ocorreu de forma voluntária no Setor de Telemarketing Ativo, pois os trabalhadores foram convidados a participar deste projeto, lembrando que só uma porcentagem estaria participando. Para a participação na aplicação do questionário e entrevistas qualitativas no Setor de Acabamento os trabalhadores foram selecionados.

Os trabalhadores que participaram da pesquisa receberam um Termo de Consentimento pós-informação, seguindo as normas do Comitê de Ética da Faculdade de Saúde Pública da USP para pesquisas com seres humanos (Anexo 1). 0 início dos trabalhos só ocorria após os trabalhadores terem concordado com o termo de consentimento e 0 assinado. $O$ pesquisador ficou com uma cópia e o trabalhador com a outra.

\subsubsection{Questionário}

$\mathrm{Na}$ amostra selecionada foi aplicado um questionário amplamente usado em estudos sobre fadiga (Wessely et al. 1998): a Escala de Fadiga de Chalder (Anexo II). Esse questionário se propõe a medir o que os autores denominam de fadiga profunda e fadiga crônica, sendo a fadiga profunda um estado mais transitório de fadiga do que a crônica. $O$ estado de sensação de fadiga é descrito usando palavras e sintomas. A escala de Chalder (1993) é uma escala com multi-itens que compreende sub-escalas que contém 7 itens referentes a sintomas físicos, 4 itens referentes a sintomas mentais, 2 itens sobre dor muscular e 2 itens referentes ao tempo de duração dos sintomas. 
Trata-se de uma escala tipo Likert, com 4 categorias de respostas: "muito mais que o habitual", "mais que o habitual", "o mesmo que o habitual" e "menos do que o habitual". Nesta escala as variáveis se referem a cansaço, sonolência, necessidade de repouso, dificuldade em realizar tarefas, falta de energia, diminuição da força muscular, concentração, memória, dor muscular e o tempo de ocorrência dos sintomas. Somente as respostas aos 11 primeiros itens são contados para a pontuação. Para a determinação da fadiga profunda, as categorias de respostas "menos que o habitual" e "o mesmo que o habitual", valem 0 pontos; as categorias "mais que o habitual" e "muito mais que o habitual" valem 1 ponto. $O$ indivíduo é considerado como tendo fadiga profunda quando obtiver uma soma de 4 ou mais pontos nas primeiras 11 questões da escala. Os itens sobre a duração do problema não entram na pontuação. Eles são levados em conta para definir a cronicidade da fadiga. Se a duração for 6 meses ou mais, considera-se "fadiga crônica".

No Brasil, Souza et al. (2002) e Peres et al. (2002) desenvolveram pesquisas sobre fadiga e utilizaram a Escala de Fadiga de Chalder como um dos métodos empregados.

Foram incluidas no questionário as variáveis de identificação do trabalhador: idade, sexo, estado civil, escolaridade, tempo na empresa e tempo na função e horário de trabalho. O questionário completo incluindo as variáveis de identificação é apresentado no Anexo III.

Os trabalhadores que responderam ao questionário somam 160 no Setor de Acabamento e 40 no Setor de Telemarketing Ativo ( $N=200$ ).

As estratégias de aplicação do questionário foram diferentes para os setores estudados. Para o Setor de Acabamento foram montados grupos de 10 trabalhadores de postos de trabalho semelhantes, mas distribuidos nas várias máquinas do acabamento das revistas com diferenciação no processo de automatização. As reuniões com os grupos foram realizadas em um periodo de aproximadamente 45 minutos, em uma sala para tal fim. Na sala permaneceram os trabalhadores e a pesquisadora. No primeiro momento foi 
explicado pela pesquisadora o objetivo da pesquisa e esclarecendo que se tratava de uma pesquisa sobre condições de saúde e trabalho entre trabalhadores em uma indústria gráfica.

No segundo momento, os trabalhadores responderam o questionário individualmente e as questões onde haviam dúvidas foram esclarecidas individualmente pela pesquisadora. As perguntas foram esclarecidas individualmente como uma precaução, pois a fala coletiva poderia influenciar as respostas dos outros trabalhadores.

Foram realizados 16 grupos para cobrir o conjunto de 160 trabalhadores. Toda a aplicação dos questionários foi realizada apenas pela pesquisadora.

Para o Setor de Telemarketing Ativo foi utilizada a estratégia de aplicação com os trabalhadores divididos em 2 grupos (20 em cada grupo). Foram realizadas as aplicações de questionários em um dia em que os trabalhadores reservam para discutir as estratégias de venda e avaliação do trabalho, chamado por eles de "dia do fôlego". Foi cedido pela coordenadora e supervisoras do telemarketing o tempo de 30 minutos no período da manhã para a turma do turno matutino e 30 minutos no periodo da tarde para a turma do turno vespertino. Os procedimentos para aplicação dos questionários foram os mesmos adotados para o Setor de Acabamento com a diferença de que a coordenadora e as supervisoras permaneceram na sala e também responderam o questionário.

\subsection{Avaliação da Sensação de Fadiga a Partir do Discurso dos Trabalhadores}

O método empregado nesta pesquisa visou entender o fenômeno da fadiga através da fala dos trabalhadores. O discurso dos trabalhadores foi coletado por meio de entrevistas semi-estruturadas, utilizando-se gravação magnética com a posterior transcrição literal das fitas obtidas e análise da fala dos trabalhadores com base no método do discurso do sujeito coletivo 
(Lefévre et al. 2000), por ser um método amplamente usado no campo da Saúde Pública.

É importante o emprego de uma abordagem qualitativa, pois, segundo Minayo (1992), "...a quantidade e a qualidade são inseparáveis e interdependentes...".

Simioni et al. (1996) indicam que grande parte das pesquisas qualitativas adota a "análise do discurso" já que, dar voz aos indivíduos, é uma das formas mais adequadas para operar o resgate das representações dos sujeitos. Os autores definem entrevista como "... a técnica em que 0 investigador se apresenta ao investigado e Ihe formula perguntas com 0 objetivo da obtenção de dados que interessam à investigação". De acordo com Lefévre et al. (2000):

"as abordagens de corte qualitativo permitem a compreensão mais aprofundada dos campos sociais e dos sentidos neles presentes na medida em que remetem a uma teia de significados de dificil recuperação através de estudos de corte quantitativo, em que o discurso, quando está presente, é sempre reduzido a uma expressão numérica. Isto não quer dizer que não se possa recorrer, quando necessário, a instrumentos quantitativos, fazendo uso portanto de abordagens diversificadas para a explicação da realidade". p. 15.

As entrevistas semi-estruturadas foram realizadas com um pequeno grupo escolhido a partir do total de respondentes dos questionários, procurando-se apreender como os trabalhadores compreendem o fenômeno "sensação de fadiga". Os trabalhadores foram escolhidos de uma lista de respondentes aos questionários sobre fadiga. No Setor de Telemarketing Ativo o grupo participante consistiu de $14(35,0 \%)$ trabalhadores de um universo de 40. No caso do Setor de Acabamento foram escolhidos aleatoriamente 20 trabalhadores da lista de respondentes ao questionário, que foram convidados a participar das entrevistas. Para selecionar os 20 trabalhadores foi considerado os trabalhadores com maior e menor tempo de trabalho. No total foram entrevistados 9 trabalhadores, representando $5,6 \%$ 
do total de trabalhadores $(\mathrm{N}=160)$. O grupo, portanto, contou com 23 trabalhadores, $11,5 \%$ do total em estudo $(\mathrm{N}=200)$.

Assim, o grupo do estudo qualitativo foi composto por 14 trabalhadores do Setor de Telemarketing Ativo (10 mulheres e 4 homens) e 9 trabalhadores do Setor de Acabamento (5 mulheres e 4 homens).

A entrevista teve início a partir da pergunta inicial "como você se sente no seu trabalho?". As demais perguntas foram apenas sobre afirmações feitas pelos entrevistados visando aprofundar a afirmação. Se a primeira pergunta não desencadeasse o discurso, fazia-se uma segunda pergunta: "como é o seu trabalho?". Esta pergunta visava alcançar uma relação entre o descrever o trabalho e como o trabalhador se sentia.

As duas perguntas feitas aos entrevistados funcionaram como um ponto de partida para que os trabalhadores falassem sobre o seu trabalho, seus sentimentos em relação a ele, de suas características pessoais, de como vêem a vida e o trabalho e como se sentem no dia a dia. A partir destas perguntas surgiram, no discurso, indicações de como estes trabalhadores entendem as relações de trabalho e o seu bem estar, ou seja, - quanto o trabalho pode ser cansativo ou gerar cansaço; quais as estratégias para conviver com 0 trabalho e o cansaço advindo dele; o cansaço no trabalho e fora dele; as estratégias de enfrentamento e a identificação da situação de cansaço ou fadiga, além da conceituação sobre o cansaço e a fadiga.

As entrevistas no Telemarketing Ativo tiveram a duração de trinta minutos. Este tempo foi delimitado em cima de um acordo com o setor, pois este negociou com os trabalhadores um banco de horas pelas horas empregadas nas entrevistas. As entrevistas foram realizadas antes e depois da jornada de trabalho. Ou os trabalhadores chegavam mais cedo ou saiam mais tarde para realizarem as entrevistas. Foi reservada uma sala específica para a realização da entrevista fora do ambiente de trabalho e com a permanência apenas do pesquisador e do trabalhador entrevistado. 
Já no Setor de Acabamento, as entrevistas que duraram também 30 minutos, acordados com a gerência, acabaram sendo às vezes um pouco mais longas. Houve flexibilidade do Setor para estas entrevistas que às vezes duraram de 40 a 45 minutos. A impressão é de que no setor de produção a pressão para o término das entrevistas foi "mais leve".

As entrevistas, tanto no Setor de Acabamento quanto no Setor de Telemarketing Ativo, foram realizadas no período de novembro a dezembro de 2001.

A análise das entrevistas foi realizada partindo-se da fala dos trabalhadores e de sua relação com a sensação de fadiga interpretada por Grandjean (1988) em que esta é uma sensação difusa acompanhada de uma indolência e falta de motivação para qualquer atividade, permanecendo no estado fadigado a sensação subjetiva de cansaço; com as idéias de fadiga de Cameron (1973), indicando que se deve entender a fadiga em termos de reações individuais para o estresse sobre um período de tempo, tendo origem no estado pessoal do individuo; com a expressão da fadiga em termos de sinais e sintomas físicos e mentais presentes na Escala de Fadiga de Chalder (1993) e conjugados com a técnica do discurso do sujeito coletivo (Lefrévre et al. 2000).

A Proposta do Discurso do Sujeito Coletivo (DSC) implica a utilização de quatro figuras metodológicas elaboradas para ajudar a organizar e tabular depoimentos e demais discursos. Estas figuras são: a ancoragem, a idéia central, as expressões chaves e o discurso do sujeito coletivo. Segundo Lefréve et al. (2000) quase todo discurso tem ancoragem na medida em que está sempre alirceçado em pressupostos teóricos, conceitos, hipóteses. A idéia central pode ser entendida como a(s) afirmação (ões) que permitem traduzir o essencial do conteúdo explicitado pelos sujeitos e seus depoimentos, e as expressões chaves são construídas por transcrições literais de parte dos depoimentos que permitem o essencial do conteúdo discursivo dos seguimentos em que se divide o depoimento (que em geral correspondem às questões da pesquisa). Ainda de acordo com o autor, o 
DSC busca construir com pedaços de discursos individuais, como em um quebra cabeça, tantos discursos síntese quanto se fazem necessários para expressar uma "dada" figura, ou seja, um dado pensar ou representação social sobre um fenômeno.

Assim como primeiro para a construção do discurso do sujeito coletivo nesta pesquisa foram analisados os discursos em estado bruto, dos 23 trabalhadores, extraindo-se as idéias centrais e suas respectivas expressões chaves, pautado nos conceitos de fadiga, reveladas pelo individuo em suas expressões características individuais, sinais e sintomas de fadiga, nos fatores determinantes presentes no trabalho, na identificação de uma situação "problema" apontada nos discursos.

A partir desta elaboração, o segundo passo foi somar as expressões chaves e idéias centrais para obter o DSC. Como um dos objetivos proposto nesta pesquisa foi o de comparar os resultados obtidos com os instrumentos quantitativo e qualitativo, optou-se por somar as expressões chaves e idéias centrais criando o DSC de grupos separados, ou seja, o DSC do grupo de trabalhadores com a fadiga e o DSC dos trabalhadores sem a fadiga. $O$ indicador da presença de fadiga nos trabalhadores foi apontado pela Escala de Fadiga de Chalder. 


\section{RESULTADOS}

\subsection{Conhecimento do Processo e das Condições de Trabalho}

Para uma melhor compreensão do trabalho nos Setores de Acabamento e Telemarketing Ativo e dos fatores contribuintes para a sobrecarga de trabalho descreveremos a observação do trabalho real. A observação não foi realizada de uma forma sistemática, na medida em que a discussão das causas da fadiga não é o objeto principal desta pesquisa, mas sim, complementar ao entendimento do contexto de trabalho que pode acarretar fadiga.

\subsubsection{Descrição do Trabalho no Setor de Acabamento (SA)}

Neste setor é feito o acabamento das revistas impressas na gráfica. "Acabamento" significa encaixar os cadernos das revistas em suas posições sequenciais, grampear as revistas, cortar as aparas, embalar em acondicionamentos plásticos, montar as embalagens em paletes ${ }^{6}$ colocar lacre nos paletes e encaminhar ao Setor de Expedição. O processo de trabalho é semi-automatizado: o encaixe dos cadernos formando as revistas, o corte das aparas (guilhotina) e a embalagem em plásticos é um trabalho feito pelas próprias máquinas grampeadeiras; o trabalho de alimentar a máquina, montar as embalagens nos paletes, colocar lacre (fita metálica) e encaminhar à expedição é realizado pelos trabalhadores. Os reparos ou consertos das revistas rejeitadas pela máquina também é realizado pelos trabalhadores. Aqui se controla os cadernos que devem retornar para a linha de produção ou ir para o refugo. A descrição do processo de produção no setor é apresentada na figura 1.

\footnotetext{
${ }^{6}$ Paletes são as embalagens construidas em madeira, tipo suportes, onde as revistas, depois de prontas. são acondicionadas para serem encaminhadas ao Setor de Expedição.
} 


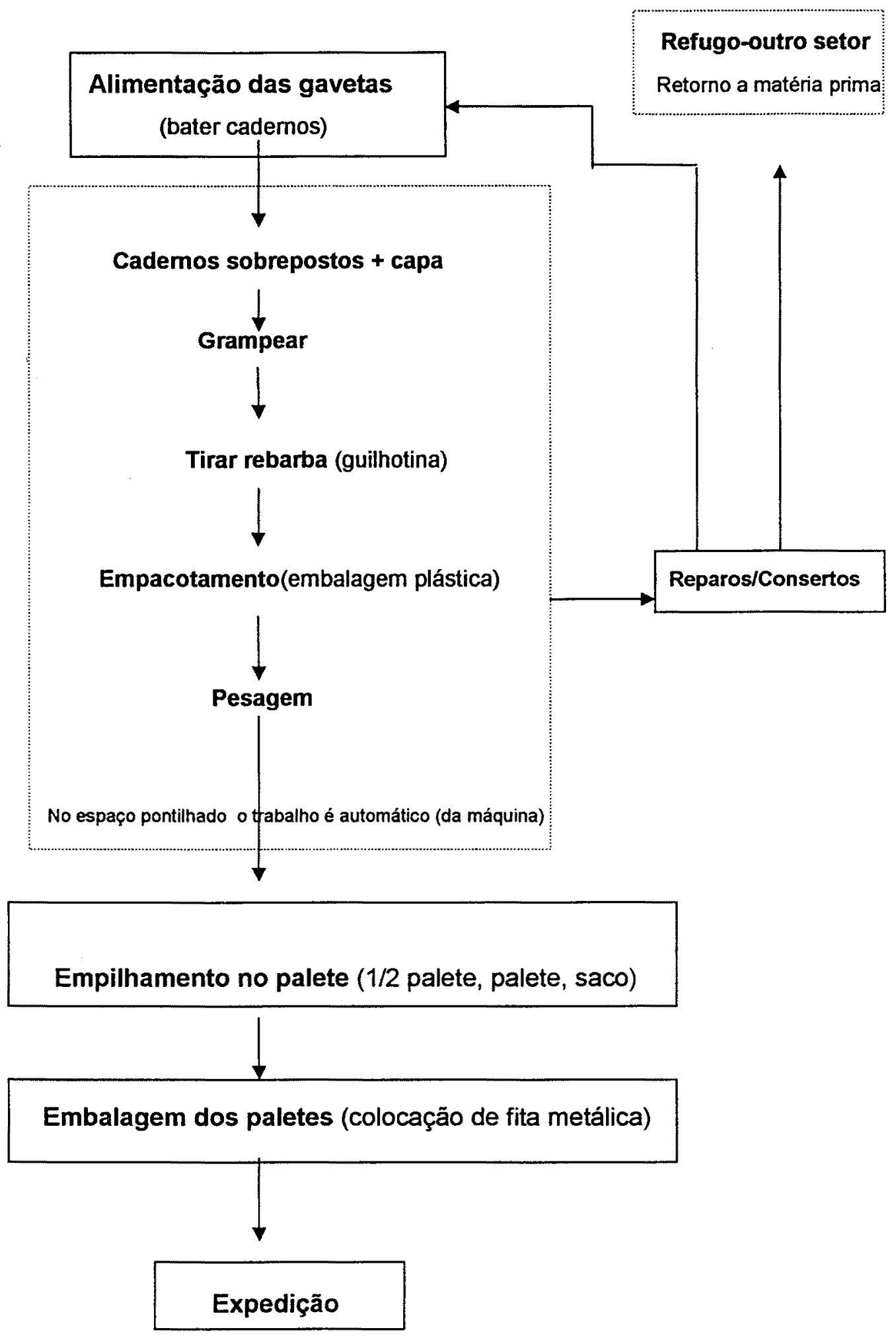

Figura 1: Esquema do Processo de Produção no Setor de Acabamento 


\section{Organização do Trabalho}

A administração deste setor é realizada pelo gerente de produção e três supervisores responsáveis pelo trabalho em cada turno (6-14h, 14-22h, 22-6h). Com cada supervisor trabalham 2 operadores de apoio (também denominados de encarregados). $\mathrm{Na}$ entrada do setor existe um grande painel na parede que indica toda a divisão das equipes de trabalho por máquinas e turnos. Esta divisão é feita diariamente pelos encarregados e/ou engenheiro de produção responsável por aquele determinado turno. Não há rodizios sistemáticos entre as atividades.

O trabalho no chão da fábrica ${ }^{7}$ é realizado por operadores 1 que "batem os cadernos ${ }^{8 n}$ e os colocam nas gavetas das máquinas. Esses operadores são denominados "gaveteiros". Os operadores 2 auxiliam o operador 1 e, quando necessário, substituem o operador 3 . Os operadores 3 controlam a máquina, também chamados de operadores de máquinas.

No momento das observações no turno matutino, o contingente de trabalhadores era de 120 , mas o setor neste turno conta com 158 trabalhadores no total. A seqüência de arranjo de turnos ocorre da seguinte forma: o gerente de produção e o encarregado da manhã determinam o arranjo da turma da tarde, os da tarde determinam a turma da noite e conseqüentemente os administradores da noite arranjam o turno da manhã. Quando o trabalhador chega no setor ele consulta o quadro para ver em que máquina ele estará trabalhando naquele dia. De acordo com nossa observação e o relato dos trabalhadores, a empresa está em uma fase de contenção de gastos e conseqüente diminuição do contingente de trabalhadores nos turnos. Isto leva a mudanças constantes de trabalhadores nas máquinas. Certas máquinas podem permanecer paradas e os trabalhadores realocados para outras máquinas, por isso o constante rearranjo do quadro de distribuição dos trabalhadores.

\footnotetext{
${ }^{7}$ Chão da fábrica é utilizado para designar o local de trabalho onde ocorre a produção propriamente dita, ou seja, onde ocorre o processo de transformação da matéria-prima até o produto final.

8."Bater os cadernos" é uma linguagem adotada pelos trabalhadores e equivale a manipular um conjunto de cadernos para separar (soltar) as folhas.
} 
Para operar a máquina (operador 3) é alocado, em geral, um trabalhador do sexo masculino, assim como para a alimentação das gavetas. As mulheres assumem mais os postos de trabalho no reparo e no fim da produção: empacotamento e expedição. Segundo informações da Gerência de Produção não existe preferência "registrada" para contratação de homens ou mulheres, "mas se tiver que ser contratado um homem ou uma mulher é escolhido o homem". O homem tem conhecimento de mecânica e a gerência incentiva que estes façam cursos". Sobre as mulheres um gerente de produção fez a seguinte referência: "em um congresso nos Estados Unidos um engenheiro de 60 anos me disse: as mulheres têm muito emotional problems, e eu não me esqueço disso". Apesar de não ser uma política explícita de contratação e divisão de trabalho em relação a gênero, isto mostra restrições ao trabalho feminino. Os gerentes da produção relatam que "para o trabalho de operação de máquina o homem é mais adequado". "É um trabalho que exige habilidade de mecânica, e as mulheres não têm este perfil, além do trabalho ser pesado para as mulheres. As mulheres se mostram mais hábeis para o reparo. Por isto são colocadas lá".

A organização do trabalho está calcada no modelo clássico: parcelamento do trabalho, sem muita oportunidade de comunicação entre os trabalhadores. A comunicação também é prejudicada pelo ruído e ritmo de trabalho. A produção é alta e o trabalho é monótono e repetitivo. É estabelecida uma rigida hierarquia de trabalho com os engenheiros de produção como responsáveis pelas tomadas de decisões, seguidos pelos encarregados e, no final da estrutura, os operadores da máquina e gaveteiros, realizando o trabalho manual. $\mathrm{O}$ operador de máquina é responsável por sua equipe de trabalho. $\mathrm{O}$ controle sobre o trabalho é extremamente rígido, como indica a seguinte fala de um dos trabalhadores, ao ser perguntado se já não tinha passado o horário de almoço: "aqui a gente come de acordo com a fome do chefe".

\section{Maquinários e Equipamentos}

O setor possui 11 máquinas grampeadeiras. As máquinas, no seu conjunto, são compostas por uma fonte de alimentação: as gavetas onde são "batidos" e colocados os cadernos; um corpo com uma esteira, onde os 
cadernos vão sendo montados um em cima do outro; uma etapa onde a máquina grampeia os cademos e a capa; um compartimento com uma guilhotina que apara as rebarbas e dá a formatação final à revista; uma embaladora, com uma esteira que leva o pacote embalado para o final da linha; uma balança onde é registrado o peso do pacote; e finalmente uma mesa receptora. A máquina trabalha automaticamente, "parando" quando em algum lugar do processo ocorre um problema com a fabricação. As máquinas são de procedência suiça ou norte americana e não são todas iguais, pois possuem datas de fabricação diferentes, sendo a mais antiga de 1972 e as mais novas de 1997.

As máquinas mais novas possuem alimentação automatizada dos cadernos, denominada de gaveteiro automático, o que diminui a carga de trabalho para os operadores 1 e 2, responsáveis pela alimentação. As máquinas de fabricação mais antigas possuem gaveteiros manuais.

Após a fabricação, os pacotes com revistas são embalados de três formas diferentes: em sacos, meio paletes ou paletes identificados respectivamente pelas letras $S, M P$ e $P$.

Os pacotes de revistas formados pela embaladora têm pesos diferentes dependendo do tipo e dimensões da revista produzida. Se o peso do pacote é maior, a freqüência de produção pode ser reduzida, isto é, diminui-se a velocidade da esteira; se o peso é menor, pode ocorrer o processo inverso, ou seja, um aumento da velocidade de produção.

A seguir, apresentamos uma breve descrição de cada tipo de atividade:

(1) alimentação manual de gavetas,

(1a) alimentação automática de gavetas,

(2) embalagem, saida das revistas,

(3) reparo das revistas,

(4) expedição. 


\section{(1) Alimentação Manual de Gavetas}

Cada máquina contém 10 gavetas. A montagem da revista ocorre da esquerda para a direita conforme o desenho esquemático apresentado na figura 2.

\section{Direção da confecção dos cadernos}

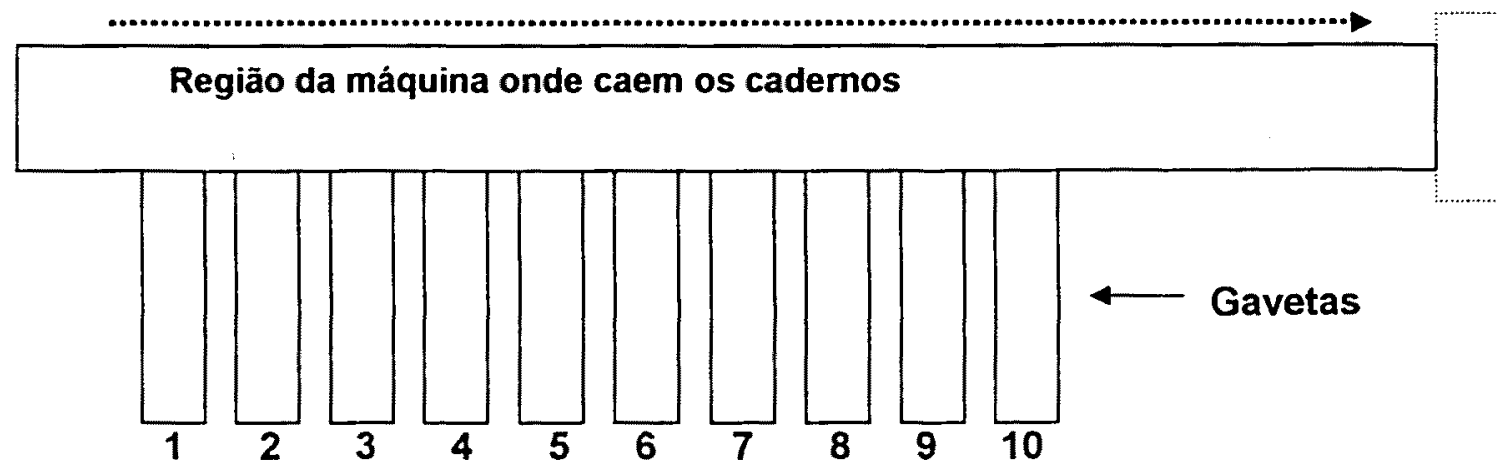

Figura 2 - Desenho esquemático da esteira de produção e das gavetas de alimentação.

Cada trabalhador alimenta duas gavetas na seqüência, ou seja, gavetas 1 e 2; ou 3 e 4; etc. Assim, tem-se um total de 5 trabalhadores para alimentação de cada máquina. Este número pode cair para 4 se faltarem trabalhadores.

Os trabalhadores alimentam as gavetas em um processo continuo, pois estas máquinas têm velocidade acelerada e uma capacidade de produção que pode variar: dependendo do produto elas podem fabricar de $11 \mathrm{mil}$ a $78 \mathrm{mil}$ revistas/hora, o que ocorreu durante nossas observações. O trabalho de alimentação da gaveta contempla duas tarefas básicas: retirar fardos com cadernos dos paletes e alimentação das gavetas.

Na primeira tarefa, o trabalhador retira os fardos contendo os cadernos, , de um palete situado às suas costas e coloca o fardo no chão, em um espaço mais próximo da gaveta. Para retirar o fardo do palete o trabalhador levanta, sem ajuda e manualmente, o fardo que pesa aproximadamente $75 \mathrm{~kg}$. Os fardos ficam posicionados sobre paletes que se originam do setor de impressão. Os paletes são colocados em estrados de madeira a aproximadamente $30 \mathrm{~cm}$ do piso. Cada um deles vem amarrado com fitas e com tábuas de proteção nas extremidades. Quando o fardo è retirado do palete, este é colocado no chão, o 
lacre é retirado, a madeira da parte superior é retirada e guardada na "prateleira" da máquina e os cadernos são retirados para alimentar as gavetas. O gaveteiro retira o palete vazio e o coloca na frente do posto de trabalho para a empilhadeira recolher. Os lacres são colocados em grandes sacos próprios para este fim. Para colocar o fardo em pé, no chão, o trabalhador o puxa pela fita do lacre fazendo um braço de alavanca com o corpo. Ele usa o corpo como contra-peso para aparar o fardo. Para realizar este trabalho o operador faz uma semi-flexão de coluna lombar e desenvolve força com os membros superiores. Desamarra o fardo com as mãos e solta o lacre. Com os membros superiores balança o fardo. Bate o pacote na bancada, solta com movimentos de mãos. Para retirar a fita de naylon que envolve o fardo o trabalhador realiza flexão lateral de coluna torácica. Aqui é importante indicar que durante a manipulação da fita de naylon pode ocorrer cortes nas mãos e o fardo pode cair sobre o trabalhador ou podem se desequilibrar caracterizando, portanto, uma situação de risco de acidente no trabalho.

Para alimentar a gaveta o trabalhador pega os cademos retirados do fardo e os coloca sobre a bancada. Quebra a lombada, "bate os cadernos", coloca na gaveta, empurra e bate para cima. "Bater os cadernos", conforme já citado, quer dizer soltar as folhas, desprender umas das outras. Para bater os cadernos os membros superiores ficam em semi-flexão de cotovelo, extensão de punho e polegar em oponência aos outros dedos para prender os cadernos.

gaveteiro, durante a quebra do caderno e da capa, suporta um peso que varia de 2 a 7 quilos.

Quando vai alimentar a gaveta, o trabalhador às vezes pega apenas a quantidade suficiente para alimentar uma gaveta e às vezes uma quantidade maior, alimentando duas gavetas ao mesmo tempo. Quando o fardo está completo, em sua maior altura, o trabalhador pega a quantidade suficiente para alimentar as gavetas diretamente. Quando o fardo chega à meia altura, ele pega quantidades maiores de cadernos e os coloca sobre a bancada para ir separando os cadernos e alimentando as gavetas, pegando os cadernos dessa pilha. Há momentos em que o trabalhador pode fazer uma micropausa 
encostado no fardo. Observamos que perto dos postos de trabalho não há cadeiras ou bancos para descanso. O trabalho é realizado na postura em pé.

O trabalhador que alimenta a máquina com o primeiro cademo faz também a alimentação da capa. $\mathrm{Na}$ alimentação das gavetas de capas o trabalhador "amassa" (aperta) com as mãos as beiradas das folhas.

No momento das observações havia 4 trabalhadores para 10 gavetas ativadas (todos trabalhadores do sexo masculino), alimentando a máquina que estávamos observando. Quando perguntado sobre o fato de não haverem mulheres trabalhando nas gavetas, o encarregado de uma máquina disse que "no sábado as mulheres vão para o fim da linha (embalagem) porque elas têm restriçōes, todas tem tendinite, tenossinovite, aquele problema de punho, por isto têm restrições. Elas ficam no trabalho de reparo".

Ao chegar ao final do processo automático, a revista é "virada", isto é, ela é "fechada". Quando um tipo de revista "vira", é necessário tirar a Primeira Mão: são revistas que vão para os editores, presidência da empresa, aeroporto, etc. As que vão para a presidência ou diretoria servem como controle de qualidade. Mesmo sendo a mesma revista na capa, há diferentes tipos de acordo com as localidades onde as revistas são vendidas (Rio, São Paulo, Belém, Belo Horizonte, etc.), uma vez que há mudanças nas propagandas. Existe um trabalhador encarregado da tirada da "Primeira Mão", trabalho que envolve a seleção, inspeção e controle de qualidade, realizado em pé.

A produção ocorre em condições de velocidade, dificultando a adequada alimentação das gavetas. Foi obtida a média aproximada de um abastecimento a cada 14 segundos, com 4 gavetas sendo abastecidas pelo mesmo trabalhador. O tempo entre 0 abastecimento das gavetas é preenchido com operações de preparação, tais como a quebra de cadernos e pegar mais cadernos no palete. Durante a observação do trabalho obtivemos que em 12 minutos o trabalhador pegou o fardo do palete para alimentar as gavetas 3 vezes e alimentou as gavetas num total de 40 vezes. $O$ tempo gasto para "bater os cadernos" foi, em média, 7 segundos. 
Os trabalhadores da máquina que mais produz recebem um prêmio no final do mês e também existe um prêmio para aqueles trabalhadores da máquina que mais rodar durante $o$ ano.

O turno de trabalho que mais sofre com a produção das revistas é aquele onde ocorre o fechamento da produção, geralmente o turno das 6:00 às 14:00horas.

\section{- Aspectos críticos do posto de trabalho}

Nestes postos de trabalho o gaveteiro manipula um peso que varia aproximadamente de 2 a $7 \mathrm{~kg}$. Nesta operação, as mãos fazem uma série de movimentos dentre os quais o de pega em extensão combinada com aplicação de força e torção de punho. Esses movimentos são realizados repetitivamente em uma freqüência aproximada de 8 a 9 vezes por minuto. Os gaveteiros têm que colocar os pacotes a $40 \mathrm{~cm}$ ou mais do corpo para posicioná-los dentro da gaveta o que faz com que inclinem a coluna. $\mathrm{Na}$ ação muitas vezes o peso do corpo é usado sobre os braços para que os cadernos possam ser corretamente quebrados. O número de cadernos manipulados a cada vez faz com que o operador tenha que fazer uma abertura excessiva da pega da mão (distância entre o polegar e o indicador na pega em pinça).

Um problema observado é que os fardos têm altura de aproximadamente $1,20 \mathrm{~m}$ e quando são retirados cadernos do início do fardo a maior força é de membros superiores e sustentação de um braço de alavanca. Quando o fardo está em uma altura de aproximadamente $0,60 \mathrm{~m}$ o problema é no levantamento de peso e a flexão antero/lateral da coluna lombar.

Muitas vezes a produção ocorre em condições de velocidade alta, dificultando a adequada alimentação das gavetas. O operador manipula a velocidade da máquina de acordo com a exigência de produção em um determinado momento. Se a velocidade é alta, todas as conseqüências dos movimentos inadequados, detectados na observação, são agravados. Uma outra questão é o contingente diminuído de trabalhadores. Por exemplo, na alimentação das gavetas existiam 4 trabalhadores para 10 gavetas e dois destes trabalhadores eram sobrecarregados com a alimentação de 3 gavetas. 
A altura da bandeja, dependendo da estatura do gaveteiro, fica alta ou baixa levando a um posicionamento inadequado dos braços e do tronco.

Todo o trabalho é realizado sem a inserção de pausas adequadas que promovam o descanso muscular e mental.

\section{(1a) Alimentação Automática de Gavetas}

Algumas máquinas possuem o chamado gaveteiro automático. Nessas máquinas, a alimentação dos cadernos é feita através de uma ponte rolante com comando manual, eliminando a "quebra dos cadernos". No resto, o tipo de trabalho é o mesmo das outras máquinas. A capa é colocada manualmente.

A ação do gaveteiro é direcionar os pacotes para as gavetas de alimentação, controlando a movimentação da esteira através de um botão. Às vezes é necessário que os trabalhadores ajeitem os pacotes de cadernos. Mas o trabalho de manipulação dos cadernos é praticamente eliminado neste tipo de máquina, facilitando 0 trabalho. No entanto, 0 trabalhador aciona constantemente o botão de controle da esteira, utilizando o polegar direito.

Não ficou claro como ocorre a seleção para o trabalho nesta máquina, se por tempo de trabalho ou revezamento aleatório.

\section{(2) Embalagem, saida das revistas}

As revistas em pacotes, embaladas em plásticos, pesando $15,96 \mathrm{~kg}$, são retiradas da esteira pelos trabalhadores e colocadas nos paletes para seguir para a expedição. Conforme já mencionado, as embalagens podem ser de 3 tipos: (1) Palete, (2) Meio Palete e (3) Sacos. A quantidade de pacotes a serem colocados em cada palete depende do seu destino. O empilhamento de meio palete é de aproximadamente 3 ou 4 andares de pacotes de revistas. $O$ suporte do palete é giratório. Em 5 minutos o trabalhador colocou 27 pacotes no palete.

O trabalho de embalagem "saída das revistas" contempla 5 tarefas básicas:

1. Pegar o pacote na esteira de saída

2. Girar o pacote para observar os 4 lados (controle de qualidade)

3. Colocar o pacote no palete 
4. Girar o palete de tempos em tempos para ir colocando os pacotes de maneira uniforme

5. Controlar a qualidade das revistas e da embalagem

Além de o trabalhador fazer o controle de qualidade do pacote de revistas ele deve também fazer o controle da etiqueta do palete. Esta ficha contem as informações de quantas revistas deve ter no palete e o destino deste. Estas fichas/etiquetas de cada remessa são confeccionadas, diariamente, por uma trabalhadora no escritório do setor de acabamento. Para realizar o controle da ficha do palete é necessário que o trabalhador conte quantas revistas já estão no palete. Pela nossa observação este é um processo rápido e depende do aprendizado diário que o trabalhador desenvolve, realizando sempre o mesmo serviço. Assim, o trabalhador já sabe quantos pacotes o palete deve conter.

\section{Posturas no trabalho de saída das revistas.}

O trabalhador pega o pacote contendo 20 revistas com o membro superior direito e o levanta trazendo para si com a ajuda do membro superior esquerdo. Bate as revistas na mesa com os dois membros superiores, para isso utiliza o cotovelo em flexão, sem apoio, as mãos com extensão de punhos e flexão de dedos, segurando o pacote com as revistas.

Quando o empilhamento é na parte de baixo do palete o trabalhador faz flexão de coluna para empilhar em baixo. Quando o empilhamento é na parte de cima do palete a exigência recai nos movimentos de ombros (flexão) e membros superiores (elevação). Quando a embalagem é em sacos, estes são colocados manualmente nos paletes, e neste caso ocorre carregamento e levantamento de peso.

Acontecem momentos em que o trabalhador pega dois pacotes de revistas ao mesmo tempo e faz o controle de qualidade. Chegamos a observar o trabalhador pegando 3 pacotes de uma vez. Às vezes, acumulam-se pacotes no fim da saída da máquina quando, por exemplo, o palete cheio não foi ainda retirado.

Durante as observações verificamos o preenchimento de um palete com 15 pacotes no "lastro" e 8 andares, isto é, 8 andares de 15 pacotes cada e 
também o preenchimento de outro palete com 9 andares realizado em um tempo de 10 minutos.

$\mathrm{Na}$ embalagem para os assinantes, segundo informação dos trabalhadores, "o grande problema é ensacar", ou seja, a embalagem em sacos.

$O$ trabalho na embalagem é muito rápido, com movimentos repetidos em um curto intervalo de tempo, com adoção de flexão de tronco, flexão e extensão de ombros, cotovelos sem apoio e elevação de membros superiores.

\section{- Aspectos críticos do posto de trabalho}

Neste posto de trabalho o trabalhador levanta e carrega peso com repetição de movimentos em ciclos curtos de trabalho e adoção de posturas antinaturais ${ }^{9}$ para colocação dos pacotes nos paletes. $O$ trabalho é realizado em ritmo acelerado. Os pacotes com aproximadamente 8 quilos são levantados e carregados 27 vezes em 5 minutos.

O maior problema deste posto é a embalagem tipo sacos, pois o operador pega o saco do chão depois de cheio e para isto faz uma flexão anterior da coluna.

\section{$\Rightarrow$ Uma Variação do Trabalho na Saída de Revistas}

Existem duas máquinas que não possuem uma esteira completa como as outras, ou seja, existe um intervalo entre a saída das revistas e a embalagem. Assim, o trabalho de empacotamento, normalmente automático, nessas máquinas é feito manualmente. Para isso, são alocados três trabalhadores que ficam no espaço entre a saída da revista e o início da embalagem. A função desses trabalhadores é retirar as revistas prontas, compor os pacotes a serem embalados e colocá-los na linha de embalagem.

As tarefas principais são:

\footnotetext{
${ }^{9}$ Segundo Queiroz (1998) a postura é uma atitude adotada pelo corpo; disposição do corpo no espaço. Uma postura natural deve ser aquela onde, segundo os princípios da biomecânica, as articulações ocupem posição neutra, ou seja, sem movimentos, por exemplo, de extensão ou flexão ou inclinação. Deve ser uma postura que não se requeira grande esforço para mantê-la e assim não prejudique o organismo, não crie sobrecargas funcionais ou condiçōes em que a longo ou curto prazo possam originar processos patológicos.
} 
1. Pegar as revistas para montar blocos com 20 revistas

2. Ajeitar o bloco em cima da mesa

3. Colocar este bloco na esteira para proceder à embalagem plástica.

Dos três trabalhadores que estavam exercendo essa função no momento das observações, dois trabalhavam recepção das revistas finalizadas e colocação destas na esteira (um homem e uma mulher) e um no controle de qualidade.

O desenho esquemático deste tipo de máquina é apresentado na figura 3.

Figura 3 - Desenho esquemático da saída das revistas e linha da embalagem plástica (sem escala).

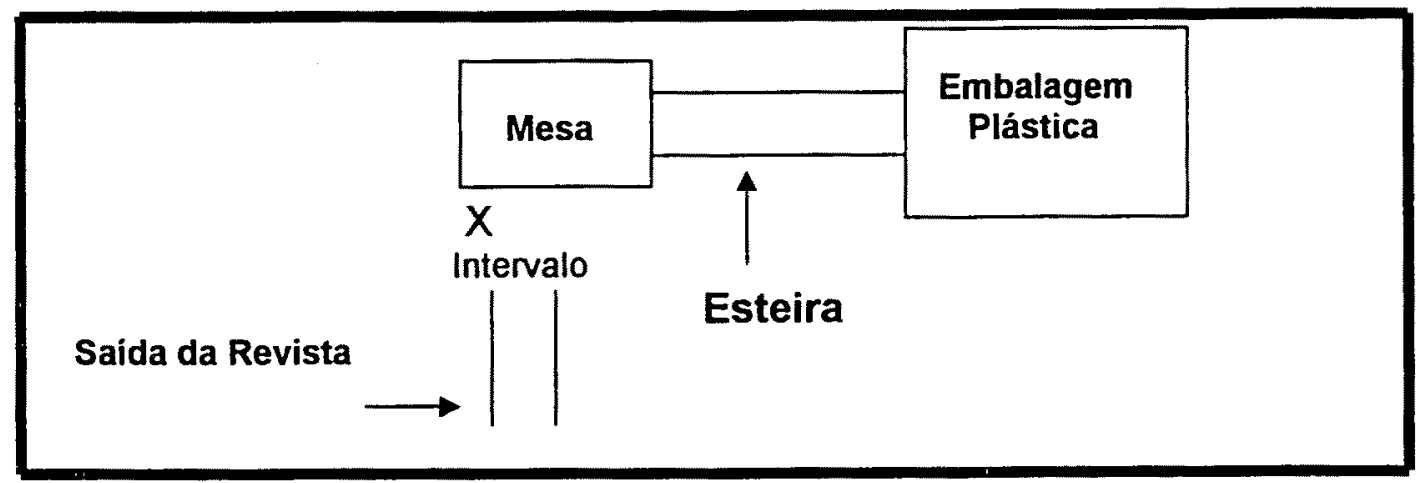

O trabalhador pega as revistas, ajeita na mesa, monta o pacote e coloca uma etiqueta, chamada pelos trabalhadores de "filipeta". O quadro 4 mostra o tempo de trabalho nesse posto.

Quadro 4: Ritmo de trabalho no posto de empacotamento.

\begin{tabular}{|l|l|c|l|}
\hline Trabalhador & $\begin{array}{l}\text { Tempo } \\
\text { Observação }\end{array}$ & $\begin{array}{c}\text { Quantidade de pacotes } \\
\text { de 20 revistas feitos }\end{array}$ & Tempo Médio \\
\hline $\begin{array}{l}\text { Mulher } \\
\text { (Observação 1) }\end{array}$ & 4 minutos & 14 & 10,2 segundos por pacote \\
\hline $\begin{array}{l}\text { Mulher } \\
\text { (Observação 2) }\end{array}$ & 7 minutos & 18 & 10,8 segundos por pacote \\
\hline Homem & 3 minutos & --- & 11,3 segundos \\
\hline
\end{tabular}

Pode ser observado no quadro acima que o intervalo de tempo empregado na montagem do pacote é curto para a quantidade de pacotes finalizados, levando à repetitividade de movimentos e a um ritmo acelerado de trabalho.

O trabalho é realizado sempre na postura em pé. 
Uma trabalhadora deste posto relatou que "é necessário modernizar as máquinas se não os trabalhadores não ganham prêmio. Com esta máquina é impossivel ganhar o prêmio, pois ela nunca vai produzir igual às outras".

\section{- Aspectos críticos do posto de trabalho}

Neste trabalho ocorre o levantamento e carregamento de peso de modo repetido e em intervalos curtos de tempo. $O$ trabalho é realizado na postura em pé durante toda a jornada. O trabalho exige atenção e concentração, além de habilidade manual. Não existem pausas programadas, durante a jornada de trabalho.

\section{(3) Reparo das Revistas}

Este posto de trabalho é ocupado por mulheres. As trabalhadoras fazem a recuperação dos cadernos e capas que não aprovados no controle de qualidade e os que foram "jogados fora" do processo de produção da máquina. Este problema pode ocorrer durante a produção, quando a própria máquina rejeita a revista, ou no final da linha, quando do controle de qualidade. As trabalhadoras do reparo separam as capas e cadernos reutilizáveis e os encaminham, colocando-os em um carrinho, para retorno ao processo de produção.

O trabalho de reparo das revistas contempla 3 tarefas básicas:

1. Desgrampear as revistas, soltando os cadernos

2. Separar os cadernos e juntar os cadernos iguais

3. Colocar em um carrinho para serem encaminhados ao local apropriado (refugo ou retomo à máquina)

A trabalhadora faz uso de alicate para desgrampeamento das revistas com defeito. Quando faz o desgrampeamento a trabalhadora separa os cadernos e a capa. Ela relata que "aqui dói mais o braço do que na gaveta". A trabalhadora observada refere ter "tendinite e hérnia na coluna" e relata: "aqui não tem para onde correr, tem que fazer". Também refere que há máquinas em pior estado, com problemas na produção e que necessitam de 3 pessoas no 
reparo. "A produção da máquina é que indica o tom da produção do dia, se a produção é ruim ocorre muita parada, ocorrem problemas, por exemplo, de "comer folhas" etc., então tem mais trabalho no reparo" (sic).

Chama a atenção na observação que este é um posto de alocação de mulheres com Lesões por Esforços Repetitivos/Distúrbios Osteomusculares Relacionados ao Trabalho (LER/DORT), mas ele apresenta tarefas com exigências maiores do que o posto de trabalho na gaveta ou saída das revistas.

\section{Posturas no trabalho de reparo das revistas}

A postura adotada para "desgrampear" os cadernos exige que a trabalhadora apóie o braço esquerdo sobre a revista e realize extensão de punho para segurar as bordas das revistas e inclinação de tronco (flexão anterior). Com o membro superior direito ela usa o alicate, arrancando os grampos. O cotovelo fica sem apoio, ocorre semiflexão de coluna e desenvolvimento de força para arrancar os grampos com o alicate.

$O$ trabalho exige que se faça movimento de pinça fina com o polegar e $o$ indicador ou com o polegar e $\circ 3^{\circ}$ dedo. É um movimento de separar os cadernos usando os dedos como separadores. A trabalhadora realiza movimento de punho com os membros superiores sem apoio de cotovelo, em pé e apoiada na mesa com discreta flexão de tronco. O movimento é realizado com rapidez. A trabalhadora gasta em média 2 segundos e realizou o mesmo movimento entre 20 a 30 vezes em 1 minuto.

\section{- Aspectos críticos do posto de trabalho}

As tarefas exigem que a trabalhadora permaneça em pé durante toda a jornada. O trabalho exige atenção, concentração, habilidade manual e desenvolvimento de força para soltar os cadernos. Os movimentos realizados são repetidos em curto espaço de tempo. Não existem pausas programadas, durante a jornada de trabalho. 


\section{(4) Expedição}

Neste posto ocorre o fechamento dos paletes que chegam do Setor de Acabamento, já montados, e são encaminhados para a expedição.

O trabalho é composto pelas seguintes tarefas:

1. Colocar uma madeira em cima dos paletes já montados

2. Passar a fita prendendo os paletes com as duas madeiras colocadas para sustentar as revistas

3. Encaixar o equipamento, ferramenta, que aperta a fita.

4. Fazer o devido aperto e corte a fita

As fitas ficam em um carrinho. Primeiro o trabalhador empurra o carrinho de fitas até os paletes a serem finalizados. Para passar as fitas pelos lados do palete o trabalhador adota flexão de tronco. Quando a fita já foi colocada o trabalhador a ajusta apertando em movimento contínuos realizados em uma alavanca que vai apertando a fita. Os movimentos realizados pelo trabalhador são repetidos em um intervalo curto de tempo, utilizando o ombro, cotovelo e punhos. Este movimento de apertar a fita para prender as revistas no palete dura de 3 a 8 segundos aproximadamente, pois depende do tamanho do palete, principalmente sua altura. Enquanto observamos pode ser notado que o ciclo total de trabalho variou de 22 a 27 segundos, desde a colocação da fita até deixar o palete lacrado para a expedição.

Durante a observação desse posto de trabalho três trabalhadores cantavam a música de abertura da novela "Escrava Isaura" exibida na televisão há alguns anos atrás. Quando comentamos sobre o fato de estarem cantando a música de fundo referente à própria escrava Isaura um dos trabalhadores respondeu: "Sim!!!! É trabalho escravo mesmo!!!".

\section{- Aspectos criticos do posto de trabalho}

Este é um posto de trabalho onde as tarefas exigem a adoção da postura em pé e agachado durante toda a jornada de trabalho. Estas posturas adotadas levam o trabalhador a realizar flexão de tronco, pois os paletes se encontram no chão. O trabalho é realizado sob pressão, pois este é considerado o fim da linha 
de produção e as revistas acondicionadas nos paletes têm horário para serem entregues aos clientes.

Conversando com um trabalhador sobre a fadiga no trabalho este relatou que: "aqui não é nem o trabalho que dá fadiga na gente, mas a pressão do patrão". Interessante é a percepção de que a "pressão do patrão" pode não fazer parte do trabalho.

\subsubsection{Descrição do Trabalho no Setor Telemarketing Ativo (STA)}

O setor é composto por 40 trabalhadores com as funções de operador, supervisor, coordenador e gerente de telemarketing.

A observação foi realizada no inicio de maio de 2002. Este é um período de fechamento das vendas do mês. A observação contemplou o penúltimo dia antes do fechamento do mês. Este geralmente é um dia de tensão no trabalho porque todos os trabalhadores devem estar fechando a meta do mês. A meta se refere ao número de recuperações de assinaturas das revistas mais importantes da editora.

Foram feitas observações com duas trabalhadoras que ocupam postos de trabalho contiguos. A operadora trabalha sentada durante toda a jornada, fazendo uso do telefone e microcomputador.

A finalidade do trabalho é recuperar assinantes que por motivos vários sofreram o cancelamento de sua assinatura. Os trabalhadores ligam para os assinantes e procuram trazê-los de volta para a assinatura ativa.

O trabalho é realizado em cima das metas estabelecidas no início do mês. O departamento de vendas, junto com o departamento específico de telemarketing ativo, calcula, mensalmente, os números de renovação que os trabalhadores precisam alcançar. A partir desta determinação, os trabalhadores recebem um "mailing" com o nome de assinantes por revistas que devem ser contatados. As revistas são classificadas por importância das assinaturas, ou seja, a assinatura de algumas revistas tem mais peso que outras.

$O$ objetivo principal do trabalho é o contato com $O$ assinante $e$ as estratégias empregadas para efetuar a renovação da assinatura, considerada aqui como uma venda. Segundo relato dos trabalhadores, ocorre um contato 
intenso diário com vários tipos de pessoas que "nós não estamos vendo pessoalmente, mas estamos falando com pessoas que hoje podem estar bem humoradas e amanhã mal humoradas" (sic).

\section{A organização do trabalho}

A jornada de trabalho é dividida em dois turnos de trabalho: de 8:00 às 14:00 horas e das $15: 00$ às $21: 00$ horas. Para as funções de coordenadora, supervisora e gerente, o turno de trabalho é fixo, com horários das 10:00 às 19:00 horas para a coordenadora e 8:00 às 17:00 horas para supervisora e gerente.

O trabalho é definido pela gerência de acordo com as metas de recuperação de assinaturas. Também são planejadas campanhas de vendas de determinadas revistas, por períodos limitados. Para estas campanhas são estabelecidas metas de vendas a serem cumpridas.

No contato com o assinante os trabalhadores adotam um nome fictício estabelecido para este fim, visando protegê-los de perseguições pessoais. Quando o trabalhador é contratado ele recebe um treinamento sobre o desenvolvimento do trabalho. Durante o dia de trabalho, eles são monitorados com uma escuta de seu contato com o assinante. Este monitoramento é aleatório, e não constante, podendo, portanto, ocorrer em qualquer periodo da jornada, com qualquer trabalhador. Quando o monitoramento detecta uma "falha" na comunicação do trabalhador com o assinante, o trabalhador é comunicado e recebe orientações sobre como proceder quando ocorrer situação semelhante".

Todo primeiro dia do mês ocorre uma parada e os trabalhadores se reúnem com as chefias para discutir as estratégias do mês que passou e serem comunicados das novas metas e estratégias para o mês em curso. Este dia é denominado "dia do fôlego" e é quando todas as dificuldades no trabalho são discutidas pelos trabalhadores do setor.

Os trabalhadores recebem um salário fixo mais uma comissão de venda. $A$ comissão de venda depende do "peso" da revista para a editora. Quanto mais se recupera as assinaturas de revistas de maior tiragem, maior será o salário no final do mês. A listagem entregue aos trabalhadores no inicio do mês contém ex- 
assinantes de revistas diversas com um número maior de ex-assinantes de revistas de maior vendagem. A composição final do salário depende da confirmação da renovação das assinaturas. As recuperações com retorno garantido são aquelas pagas por débito em conta e cartão de crédito. As recuperações pagas por boleto bancário não são garantidas até que o cliente realmente efetive o pagamento. A comissão que compõe o salário pode aumentálo em 2 a 3 vezes do valor inicial.

Nos dias de fechamento da meta mensal, para alavancar as vendas, segundo informações da supervisora, é adotado um sistema de incentivo chamado de "dinheirinho ou ligadinho". Funciona da seguinte forma: os trabalhadores pegam vales, "dinheirinho", e, quando vendem uma revista de "peso", se dirigem à mesa da supervisora e os trocam por brindes. Os brindes podem custar vários vales. Por exemplo, o brinde desejado pode custar $3,4,5$, ou mais "ligadinhos". A cada assinatura recuperada se ganha um "ligadinho", sendo que a recuperação de uma revista de "peso" vale dois "ligadinhos". Segundo informações da supervisora, os brindes são adquiridos com uma verba fornecida todo mês para promover brincadeiras e suprir outras necessidades. A idéia dos brindes surgiu da chefia para incentivar os trabalhadores. "Além de um incentivo, funciona também para distrair um pouco da tensão" (sic). Também são entregues no "dia do fôlego" as listas contendo as recuperações finalizadas.

Existe também um controle interno da quantidade de assinaturas recuperadas hora a hora. Um dos trabalhadores passa pelos boxes perguntando quantas assinaturas de revistas de "peso" foram recuperadas durante aquela hora. Esses dados são repassados para a supervisora que anota, em um "flip chart", a quantidade de assinaturas recuperadas naquela hora e quantas faltam para fechar a meta mensal do setor. O "flip chart" é colocado em um local que os trabalhadores podem visualizar empurrando as cadeiras para fora de seus boxes.

Quando a situação está tensa no setor, por falta de recuperação de assinaturas, os trabalhadores dão uma parada e conversam entre eles para amenizar a situação. 


\section{O ambiente de trabalho - Arranjo físico}

O trabalho de telemarketing ativo (TA) é realizado em um salão amplo onde funcionam vários outros setores da empresa, separados por divisórias. 0 STA funciona em um espaço com 20 "boxes"ou "baias". As baias são delimitadas por divisórias e possuem, aproximadamente, 1 metro de largura. Os trabalhadores ficam posicionados de costas uns para os outros e entre eles há um corredor com uma largura aproximada de 2 metros.

Este tipo de arranjo dos postos de trabalho promove o isolamento para a realização do trabalho. As divisórias permitem que os trabalhadores se comuniquem entre si afastando as cadeiras para trás, saindo da baia, e se olhando pela lateral do "box".

\section{Equipamentos e ferramentas de trabalho}

Os trabalhadores utilizam os seguintes equipamentos:

- Tabelas de preço das assinaturas das revistas

- Microcomputador com monitor e teclado

- Telefone com "head fone"

- "Plantonics", aparelho acoplado ao telefone que permite a escuta e o controle de volume

- Lista de telefones a serem contatados

- Ficha de controle das ligações

\section{Tarefas}

O trabalho desenvolvido durante a jornada de trabalho consiste basicamente em realizar ligações para os ex-clientes. Enquanto fala ao telefone, a trabalhadora digita o nome do cliente e a ficha aparece na tela do monitor. Quando consegue uma recuperação, a trabalhadora inclui o pedido no computador só depois que desliga o telefone, mas digita os dados enquanto fala ao telefone. Além disso, ao falar ao telefone, os trabalhadores consultam simultaneamente a tabela de preços e as promoções e diversas formas de pagamentos. 
Quando inicia o mês, os trabalhadores recebem uma listagem com os telefones de clientes para aquele mês. A listagem é gerada pelo setor de vendas que detecta o cancelamento da assinatura pelo não pagamento das renovações. Para um ex-assinante ser contatado pelo STA há um intervalo, em média, de 3 a 4 meses entre o cancelamento do cliente e o contato. Antes de o cliente ser incluído nas listas do STA são tentados outros recursos para a recuperação de assinaturas através de cartas.

Ao recebem as listagens, os trabalhadores iniciam os telefonemas por onde eles próprios definem. $\mathrm{Na}$ observação do trabalho de fechamento do mês, o que os trabalhadores estavam fazendo era repassar a lista do mês para ver se ainda conseguiam mais algumas assinaturas, tentando novos contatos ou contatando os casos que ficaram pendentes, tanto no seu turno de trabalho como no outro turno. Isto porque quando os trabalhadores da manhã fazem o contato este pode ter que ser retomado à tarde e vice-versa, porque o contato tem a ver com o cliente e sua disponibilidade.

A tarefa, de acordo com o descrito, mostra que os trabalhadores têm que utilizar vários instrumentos ao mesmo tempo, utilizando a visão $e$ a audição com atenção e concentração. Isto sem contar que devem memorizar e utilizar os "scripts", isto é, o estilo padrão de comunicação com o cliente.

Em um período de 36 minutos, uma das trabalhadoras observadas, realizou 17 telefonemas. Destes, 5 pessoas não estavam, 9 não atenderam e 3 atenderam e renderam contatos. Dos 3 telefonemas que geraram conversas, apenas um resultou em renovação de assinatura.

Se a trabalhadora não escuta bem a voz do cliente, ela aumenta o volume do telefone, utilizando o aparelho "Plantonics".

Os trabalhadores desenvolvem estratégias para realizar o trabalho. Uma trabalhadora observada relatou que quando está muito tempo sem recuperar assinaturas, ela costuma telefonar para clientes de revistas mais fáceis de recuperar, para não ficar o dia todo sem fazer uma recuperação. "Quando começa o dia sem vender nada dá desânimo" (sic). Teve dias em que ela vendeu logo de manhã, antes das 9 horas, 6 assinaturas, mas também passou o resto do dia sem vender nada. Outro dia vendeu 5 assinaturas depois do almoço. "Quando 
você ouve muito "não", pelo telefone, é ruim. Aí parte para uma revista mais barata para fazer uma assinatura e, depois de elevar o ânimo, tenta uma revista mais cara". "No nosso trabalho, trabalhamos muito com a motivação. Por exemplo, certas revistas não representam boa venda, mas o impacto de ter vendido vale a pena, pois levanta o ânimo". "Quando não consegue assinatura fica sem ânimo para falar ao telefone e não convence, sem ter vendido assinaturas".

Durante o período de observação, depois de duas horas do início de sua jornada, a trabalhadora não tinha recuperado nenhuma assinatura. Depois de dois telefonemas a trabalhadora "criou coragem" (sic) e ligou para a assinante de uma revista de "peso", mas também não recuperou a assinatura. A trabalhadora observada fez então a seguinte consideração: "Venda é questão de impulso, se você der um tempo para o cliente respirar ou pensar, a venda não é realizada. Por exemplo: se você der um tempo para o cliente e ele pergunta: qual é mesmo o seu nome? Pode desistir!!! Ele não vai comprar".

Durante a observação de 1 hora e 56 minutos, das 9:18 às 11:14h, a trabalhadora realizou 24 chamadas telefônicas, conseguiu falar com 9 pessoas e recuperou apenas 1 assinatura de uma revista de pouco "peso". Uma das trabalhadoras próximas fez o seguinte comentário: "eh!!!, está ruim hoje". Outro trabalhador comentou: "Deus é pai, não é padastro".

Os gestos e movimentos realizados pelos trabalhadores durante o trabalho representam a situação de tensão do dia. Por exemplo, um trabalhador não parou de balançar o pé esquerdo no chão.

\section{Posturas de Trabalho no Telemarketing Ativo}

O trabalho é realizado sentado. A tendência dos trabalhadores é de ficarem em flexão de pescoço para poder fazer a leitura dos códigos e dos números de telefones em listas colocadas na mesa de trabalho à sua frente. Só ocorre variação da flexão de pescoço quando o trabalhador olha na tela do computador. Só nesta situação o pescoço assume uma posição próxima à neutra. 
O tronco fica em semi-flexão durante toda a jornada de trabalho. Essa postura é provavelmente decorrente da exigência de atenção e concentração, bem como da tensão resultante de um trabalho com metas.

$O$ antebraço fica apoiado na borda da mesa em seu terço proximal e os cotovelos ficam, portanto, sem apoio. A borda da mesa é arredondada. O punho esquerdo fica, geralmente, em extensão para digitar o número de telefone, cujo aparelho fica à direita do trabalhador. A cadeira utilizada possui altura e braços reguláveis.

\section{- Aspectos críticos do posto de trabalho}

Este trabalho parece possuir uma característica marcante: é "desesperador", "sem saída". Telefonar para listas e listas de clientes que desistiram das assinaturas para tentar recuperá-las, parece um trabalho sem esperança, carregado de negatividade. Além disso, o trabalho com metas e salário fixo mais comissão gera uma certa tensão entre os trabalhadores.

Do ponto de vista dos aspectos físicos do posto de trabalho, pode-se notar que a cadeira é regulável, a mesa de trabalho relativamente confortável, embora o espaço seja pequeno, e as trabalhadoras fazem uso de "head fone" individual para o trabalho. A problemática desse trabalho não está no mobiliário ou na realização de movimentos repetitivos ou aplicação de forças, mas sim no ritmo de produção e na tensão decorrente das metas de produção: é preciso "dar conta" do objetivo estabelecido para aquele determinado mês.

O trabalho exige atenção, concentração e memorização de informações, tanto as recebidas por via auditiva, faladas pelo cliente do outro lado da linha telefônica, quanto visual, que deve ser lida na tela do computador ou nas fichas de trabalho.

A postura adotada para o trabalho é estática na maior parte do tempo, sentada, com a atenção voltada para a tela do computador e 0 telefone. A postura estática também pode ser um fator de estresse e fadiga no trabalho.

A pressão exercida em relação às metas de produção não é explicita, mas ocorre de forma sub-reptícia, acentuada e constante. Há uma exigência de tempo e controles para assegurar que as recuperações de assinaturas sejam efetivadas 
em um determinado tempo. Além disso, há o pagamento efetivo por produção, dado que as comissões de vendas é que fornece a maior parte do salário.

Uma situação que oferece condição de risco, não citada, mas que pode ocorrer, é a captação de raios pelo telefone em dia de chuva, lembrando que o uso do telefone é realizado durante toda a jornada de trabalho. 


\subsection{Caracterização da População Estudada}

A aplicação do questionário, conforme já apontado na descrição do método, abrangeu um grupo de 200 trabalhadores, 40 no Telemarketing Ativo (STA) e 160 no Setor de Acabamento das Revistas (SA). Lembramos que a população estudada do STA corresponde ao total de trabalhadores do setor.

No total, $145(72,5 \%)$ trabalhadores eram homens e $55(27,5 \%)$ mulheres. A distribuição dos trabalhadores por sexo e setor de trabalho é apresentada na tabela 2 .

Tabela 2 - Distribuição dos trabalhadores (n e \%) segundo sexo e setor na indústria gráfica estudada.

\begin{tabular}{|c|c|c|c|c|c|c|}
\hline Setor & \multicolumn{2}{|c|}{ Acabamento } & \multicolumn{2}{|c|}{ Telemarketing Ativc } & \multicolumn{2}{|c|}{ Total } \\
\hline Sexo & $\mathbf{N}$ & $\%$ & $N$ & $\%$ & $\mathbf{N}$ & $\%$ \\
\hline Masculino & 136 & 85,0 & 9 & 22,5 & 145 & 72,5 \\
\hline Feminino & 24 & 15,0 & 31 & 77,5 & 55 & 27,5 \\
\hline Total & 160 & 100,0 & 40 & 100,0 & 200 & 100 \\
\hline
\end{tabular}

Pode-se observar na tabela 2 que a participação da mulher é maior no STA do que no SA. A pequena inserção das mulheres na produção está provavelmente relacionada ao modelo de organização que a empresa adota, conforme já citado na análise do trabalho e presente no discurso dos trabalhadores e encarregados do setor.

Os dados referentes à faixa etária do grupo de trabalhadores em estudo são apresentados na tabela 3 .

Tabela 3 - Distribuição dos trabalhadores (n e \%) segundo faixa etária e setor de trabalho na industria gráfica estudada.

\begin{tabular}{l|cccccc}
\hline $\begin{array}{l}\text { Faixa etária } \\
\text { (em anos) }\end{array}$ & \multicolumn{2}{|c}{ Acabamento } & \multicolumn{2}{c}{ Telemarketing } & \multicolumn{2}{c}{ Total } \\
\hline 18 & $\boldsymbol{N}$---25 & $\%$ & $\boldsymbol{N}$ & $\%$ & $\mathbf{N}$ & $\%$ \\
$25 \mathrm{I}---30$ & 54 & 33,8 & 09 & 22,5 & 63 & 31,5 \\
$30 \mathrm{I}---35$ & 54 & 33,8 & 09 & 22,5 & 63 & 31,5 \\
$35 \mathrm{I}---40$ & 24 & 15,0 & 08 & 20,0 & 32 & 16,0 \\
$40 \mathrm{I}---45$ & 14 & 8,7 & 06 & 15,0 & 20 & 10,0 \\
$45 \mathrm{I}---50$ & 09 & 5,6 & 04 & 10,0 & 13 & 6,5 \\
$50 \mathrm{I}-\mathrm{I} 63$ & 02 & 1,2 & 04 & 10,0 & 06 & 3,0 \\
Total & 03 & 1,9 & -- & -- & 03 & 1,5 \\
\hline
\end{tabular}


A faixa etária que compreende o maior número de trabalhadores é de 18 a 30 anos com 108 trabalhadores no SA e 18 no STA. A média geral de idade foi 29 anos (desvio padrão $=7,6$ anos) e a moda foi 25 anos. $63,0 \%$ (126) dos trabalhadores entrevistados estavam com menos de 30 anos no momento da aplicação do questionário.

$\mathrm{Na}$ faixa etária de 40 a 45 anos dois trabalhadores do STA ocupam os cargos de coordenação e supervisão. Já na faixa etária de 45 a 50 anos um trabalhador do STA ocupa a função de gerente.

Em relação à escolaridade dos trabalhadores analisados, 69,5\% (139) tinham segundo grau completo e $14,5 \%$ (29) segundo grau incompleto.

O tempo de trabalho na empresa e na função pode ser verificado na tabela 4.

Tabela 4 - Distribuição dos trabalhadores (n e \%) segundo tempo na empresa e tempo na função na industria gráfica estudada.

\begin{tabular}{l|rrrr}
\hline Tempo de trabalho & \multicolumn{2}{|c}{ Na empresa } & \multicolumn{2}{c}{ Na função } \\
(em anos) & $\boldsymbol{N}$ & \% & \multicolumn{1}{c}{ N } & \multicolumn{1}{c}{$\%$} \\
\hline$<1$ & 12 & 6,0 & 12 & 6,3 \\
1 I---3 & 69 & 34,8 & 73 & 38,2 \\
3 I---5 & 51 & 25,6 & 59 & 30,9 \\
5 I---10 & 42 & 21,1 & 30 & 15,7 \\
10 I--15 & 16 & 8,0 & 11 & 5,8 \\
15 e mais & 9 & 4,5 & 6 & 3,1 \\
Total & $\mathbf{1 9 9}$ & $\mathbf{1 0 0 , 0}$ & $\mathbf{1 9 1}$ & $\mathbf{1 0 0 , 0}$ \\
\hline
\end{tabular}

O tempo de trabalho na empresa e na função mostra uma maior freqüência de trabalhadores nos períodos de 1 a 5 anos, tanto para o tempo na função quanto para o tempo na empresa. Possuíam 1 a 5 anos de empresa $120(60 \%)$ trabalhadores e 1 a 5 anos na função 132 (66\%) trabalhadores. A média geral de tempo na empresa foi 8,5 anos (desvio padrão $=15,2$ anos) e a moda foi de 2 anos. A média geral do tempo na função foi 7,9 anos (desvio padrão $=15,5$ anos) e a moda correspondeu a 2 anos.

Quanto à jornada, o grupo trabalha em jornadas diferenciadas por setor: 
- no SA a jornada ocorre nos períodos de 6 a 14 horas e 14 a 22 horas com, respectivamente, $47,5 \%$ (76) trabalhadores e $52,5 \%$ (84) trabalhadores nos dois turnos. Os turnos de trabalho são fixos.

- no STA os trabalhadores estão distribuídos em 4 tipos de turnos fixos: $50,0 \%(20)$ dos trabalhadores no turno matutino que compreende 0 horário de $8: 00$ às $14: 00$ horas; $17(42,5 \%)$ trabalhadores no turno vespertino que compreende o horário de $15: 00$ às $21: 00$ horas e turnos diferenciados para a gerência, sendo de 8:00 às 17:00 horas para a coordenadora e gerente; e 10:00 às 19:00 horas para a supervisora.

Quanto ao estado civil, $46,7 \%$ (93) trabalhadores eram solteiros no momento da entrevista, $40,7 \%$ (81) eram casados e $7,0 \%$ (14) viviam juntos. Em relação às outras classificações, obteve-se que $5,0 \%$ (10) trabalhadores eram separados e apenas $0,5 \%$ (1) era viúvo. A partir desses dados foi construída uma nova variável, com duas categorias: "casado" e "solteiro", para a análise do estado civil. Para a categoria de casado foi incluída a categoria "vivendo junto" e para a categoria de solteiro foram incluídas as categorias "separado" e "viúvo". Para esta nova variável obtivemos a seguinte distribuição: $47,7 \%$ (95) dos trabalhadores eram casados e $52,3 \%$ (104) eram solteiros. Os dados relacionados ao estado civil foram então trabalhados a partir desta nova variável.

O estado civil foi analisado separadamente por sexo e obtivemos que, dentre os solteiros, $24,0 \%$ (25) eram mulheres e $76,0 \%$ (79) eram homens. $\mathrm{Na}$ categoria de casados, 31,6\% (30) eram mulheres e 68,4\% (65) eram homens. Entre os homens, ser casado ou solteiro tem uma freqüência relativamente próxima $(68,4 \%$ vs $76,0 \%)$ e o mesmo comportamento pode ser observado para as mulheres $(31,6 \%$ vs $24,0 \%)$.

A distribuição de frequência para a variável estado civil quando considerado o setor de trabalho é apresentada na tabela 5. 
Tabela 5- Distribuição dos trabalhadores ( $\mathrm{n}$ e \%) segundo estado civil e setor de trabalho.

\begin{tabular}{l|cccccc}
\hline \multirow{2}{*}{ Estado Civil } & \multicolumn{2}{|c}{ Casado } & \multicolumn{2}{c}{ Solteiro } & \multicolumn{2}{c}{ Total } \\
Setor de Trabalho & N & $\%$ & N & $\%$ & N & $\%$ \\
\hline Acabamento & 75 & 78,9 & 84 & 80,8 & 159 & 79,9 \\
Telemarketing Ativo & 20 & 21,1 & 20 & 19,2 & 40 & 20,1 \\
\hline Total & $\mathbf{9 5}$ & $\mathbf{1 0 0 , 0}$ & $\mathbf{1 0 4}$ & $\mathbf{1 0 0 , 0}$ & $\mathbf{1 9 9}$ & $\mathbf{1 0 0 , 0}$ \\
\hline
\end{tabular}

Pode-se observar na tabela 5 que não ocorre uma diferença na distribuição de casados e solteiros quando apresentados por setor, chegando a uma distribuição de $50 \%$ para casados e para solteiros no STA.

\subsubsection{Quantificação da Fadiga nos Trabalhadores Estudados}

$\mathrm{Na}$ avaliação da fadiga pela Escala de Fadiga de Chalder (1993), conforme referido no método, foram consideradas para a determinação da "fadiga profunda" somente as categorias "muito mais que o habitual" e "mais que o habitual" para se identificar o indivíduo como tendo fadiga. Assim, a análise se baseia na distribuição da freqüência dessas categorias, tanto para os sintomas físicos quanto mentais. Esta distribuição de freqüência pode ser observada no quadro 5. 
Quadro 5 - Distribuição de respostas na Escala de fadiga segundo as duas categorias de respostas "muito mais que o habitual" e "mais que o habitual" na população estudada.

\begin{tabular}{|c|c|c|}
\hline Questões & $N^{0}$ de respostas & $\%$ \\
\hline \multicolumn{3}{|l|}{ Relacionadas aos sintomas físicos } \\
\hline Sentindo cansado & 77 & 38,5 \\
\hline $\begin{array}{l}\text { Necessitando de mais descanso } \\
\text { (repouso) }\end{array}$ & 92 & 46,0 \\
\hline Sentindo com sono ou sonolento & 78 & 39,0 \\
\hline Problemas para iniciar seus afazeres & 20 & 9,1 \\
\hline Sentindo falta de energia & 51 & 25,5 \\
\hline Sente fraqueza em seus músculos & 59 & 29,5 \\
\hline Tem se sentido fraco & 35 & 17,6 \\
\hline \multicolumn{3}{|l|}{ Relacionadas aos sintomas mentais } \\
\hline Tem dificuldade de concentração & 40 & 20,0 \\
\hline $\begin{array}{l}\text { Sente a língua enrolar ou pesada } \\
\text { quando fala }\end{array}$ & 22 & 11,0 \\
\hline $\begin{array}{l}\text { Sente dificuldade em encontrar a } \\
\text { palavra certa }\end{array}$ & 34 & 17,0 \\
\hline Sente dificuldade de memorização & 43 & 21,5 \\
\hline \multicolumn{3}{|l|}{ Relacionadas a dores musculares } \\
\hline Músculos doem durante o repouso & 54 & 27,0 \\
\hline $\begin{array}{l}\text { Músculos doem após realizar } \\
\text { exercícios }\end{array}$ & 58 & 29,0 \\
\hline
\end{tabular}

No quadro acima pode ser observado que as questões com maior índice de respostas "muito mais que o habitual" e "mais que o habitual" foram para os itens sobre "se sentir com sono ou sonolento", "necessitar de mais descanso" e "se sentir cansado". A menor freqüência ocorreu na questão sobre "iniciar os afazeres". Pode-se observar também que as 
freqüências mais altas de respostas ocorreram nas questões relacionadas aos sintomas físicos e dores musculares e as mais baixas nas questões relacionadas aos sintomas mentais.

Em relação ao tempo de duração dos sintomas, as frequeências para as duas subcategorias de respostas "entre três e seis meses" e "mais de seis meses" foram de $15,2 \%(26)$ e 12,9\% (22), respectivamente. Esta é uma questão que classifica a fadiga como "fadiga crônica" ou não.

A taxa de prevalência de fadiga profunda para o grupo foi $37,5 \%$ (75) dos trabalhadores. Dos trabalhadores com fadiga profunda, $30,7 \%$ eram mulheres e $69,3 \%$ eram homens. A taxa de prevalência para os homens foi de $35,9 \%$ enquanto que para as mulheres foi de $41,8 \%$.

Daqui em diante faremos a referência à fadiga profunda apenas como fadiga.

A proporção de fadiga e não fadiga entre homens e mulheres de acordo com a prevalência encontrada é apresentado na tabela 6.

Tabela 6- Distribuição dos trabalhadores ( $\mathrm{n}$ e \%) segundo a presença / ausência de fadiga e o sexo.

\begin{tabular}{l|cccccc}
\hline \multirow{2}{*}{ Fadiga } & \multicolumn{2}{|c}{ Com Fadiga } & \multicolumn{2}{c}{ Sem Fadiga } & \multicolumn{2}{c}{ Total } \\
Sexo & N & $\%$ & N & $\%$ & N & $\%$ \\
\hline Feminino & 23 & 30,7 & 32 & 25,6 & 55 & 27,5 \\
Masculino & 52 & 69,3 & 93 & 74,4 & 145 & 72,5 \\
\hline Total & $\mathbf{7 5}$ & $\mathbf{1 0 0 , 0}$ & $\mathbf{1 2 5}$ & $\mathbf{1 0 0 , 0}$ & $\mathbf{2 0 0}$ & $\mathbf{1 0 0 , 0}$ \\
\hline
\end{tabular}

A porcentagem dos trabalhadores do sexo masculino com fadiga foi mais alta do que para o sexo feminino, mas a diferença não foi estatisticamente significativa $\left(\chi^{2}=0,60 ; p=0,43\right)$.

Quando se analisa a presença de fadiga em relação ao estado civil, observa-se uma maior ocorrência de fadiga nos trabalhadores casados e essa diferença é estatisticamente significativa $\left(\chi^{2}=7,25 ; p=0,007\right)$. Os dados referentes a esta análise são apresentados na tabela 7 . 
Tabela 7 - Distribuição dos trabalhadores ( $\mathrm{n}$ e \%) segundo a presença I ausência de fadiga e o estado civil.

\begin{tabular}{l|cccccc}
\hline \multirow{2}{*}{ Fadiga } & \multicolumn{2}{|c}{ Com Fadiga } & \multicolumn{2}{c}{ Sem Fadiga } & \multicolumn{2}{c}{ Total } \\
Estado Civil & N & $\%$ & N & $\%$ & N & $\%$ \\
\hline Casado* & 45 & 60,0 & 50 & 40,3 & 95 & 47,7 \\
Solteiro & 30 & 40,0 & 74 & 59,7 & 104 & 52,3 \\
\hline Total & $\mathbf{7 5}$ & $\mathbf{1 0 0 , 0}$ & $\mathbf{1 2 4}$ & $\mathbf{1 0 0 , 0}$ & $\mathbf{1 9 9}$ & $\mathbf{1 0 0 , 0}$ \\
\hline
\end{tabular}

* estatisticamente significativa

Quando se analisa o tempo na função dos trabalhadores com a fadiga, encontramos uma maior proporção de trabalhadores com tempo entre 1 a 3 anos na função $(27,39,7 \%)$ de um total de 68 trabalhadores que responderam a esta questão. Dos trabalhadores com tempo na função entre 3 a 5 anos apresentaram fadiga $32,4 \%$ (22 trabalhadores). Esses dados podem ser observados na tabela 8.

Tabela 8 - Distribuição dos trabalhadores ( $\mathrm{n}$ e \%) segundo a presença de fadiga e o tempo na função.

\begin{tabular}{|c|c|c|c|}
\hline $\begin{array}{l}\text { Tempo na função } \\
\text { (em anos) }\end{array}$ & $\begin{array}{c}\text { Com fadiga } \\
\left(n^{\circ} \text { e \%) }\right.\end{array}$ & $\begin{array}{c}\text { Sem fadiga } \\
\left(n^{\circ} \text { e \%) }\right.\end{array}$ & $\begin{array}{c}\text { Total } \\
\left(n^{\circ} \text { e \%) }\right.\end{array}$ \\
\hline $\begin{aligned} &<1 \\
& 1 \text { l-- } 3 \\
& 3 \text { I-- } 5 \\
& 5 \text { I-- } 10 \\
& 10 \text { I-- } 15 \\
& 15 \text { e mais }\end{aligned}$ & $\begin{array}{r}2(2,9) \\
27(39,7) \\
22(32,4) \\
10(14,7) \\
5(7,4) \\
2(2,9) \\
\end{array}$ & $\begin{array}{r}10(8,1) \\
46(37,4) \\
37(30,1) \\
20(16,3) \\
6(4,8) \\
4(3,3)\end{array}$ & $\begin{array}{c}12(6,3) \\
73(38,2) \\
59(30,9) \\
30(15,7) \\
11(5,8) \\
6(3,1)\end{array}$ \\
\hline Total $^{*}$ & $68(100,0)$ & $123(100,0)$ & 191 \\
\hline
\end{tabular}

* Dentre os trabalhadores com a fadiga 7 não responderam a esta questão e 2 trabalhadores sem a fadiga também não responderam.

Os trabalhadores que apresentam fadiga com tempo na função de 1 a 5 anos somam 49 , com uma proporção de $72,1 \%$ em relação ao total de trabalhadores com fadiga.

A relação entre o turno de trabalho e os trabalhadores com e sem a fadiga é apresentada na tabela 9. 
Tabela 9 - Distribuição dos trabalhadores (n e \%) segundo a presença de fadiga e o tempo na função.

\begin{tabular}{l|ccc}
\hline Turno de Trabalho & $\begin{array}{c}\text { Com a fadiga } \\
\left(n^{\circ} e \%\right)\end{array}$ & $\begin{array}{c}\text { Sem a fadiga } \\
\left(n^{\circ} e \%\right)\end{array}$ & $\begin{array}{c}\text { Total } \\
\left(n^{\circ} e \%\right)\end{array}$ \\
\hline $06: 00$ às 14:00 horas (SA*) & $29(38,7)$ & $47(37,6)$ & $76(38,0)$ \\
$14: 00$ às 22:00 horas (SA) & $29(38,7)$ & $55(44,0)$ & $84(42,0)$ \\
$08: 00$ às 14:00 horas (STA $\left.{ }^{\star *}\right)$ & $12(16,0)$ & $8(6,4)$ & $20(10,0)$ \\
$15: 00$ às 19:00 horas (STA) & $3(4,0)$ & $14(11,2)$ & $17(8,5)$ \\
$10: 00$ às 19:00 horas (STA) & $1(1,3)$ & -- & $1(0,5)$ \\
$08: 00$ às 14:00 horas (STA) & $1(1,3)$ & $1(0,8)$ & $2(1,0)$ \\
\hline Total & $75(100,0)$ & $125(100,0)$ & $200(100,0)$ \\
\hline
\end{tabular}

* Setor de Acabamento

** Setor de Telemarketing Ativo

Pode-se perceber que no SA não ocorrem diferenças entre as proporções de pessoas com fadiga nos diferentes turnos, ou seja, o número de acometidos é igual em todos os turnos. Se compararmos os trabalhadores com fadiga com os trabalhadores sem fadiga pode-se notar uma diferença na proporção dos trabalhadores sem fadiga no turno vespertino em relação ao turno matutino. No STA, encontramos mais trabalhadores com fadiga no turno matutino em comparação com o vespertino.

A análise da presença da fadiga por sexo apresentou uma freqüência maior para as mulheres casadas $(73,9 \%, 17)$ do que solteiras $(26,1 \%, 6)$, diferença estatisticamente significativa $\left(\chi^{2}=5,98 ; p=0,01\right)$. Esses dados podem ser observados na tabela 10 .

Tabela 10: Distribuição das trabalhadoras do sexo feminino ( $\mathrm{n}$ e \%) segundo a presença/ausência de fadiga e o estado civil.

\begin{tabular}{l|cccccc}
\hline \multirow{2}{*}{ Fadiga } & \multicolumn{2}{c}{ Com Fadiga } & \multicolumn{2}{c}{ Sem Fadiga } & \multicolumn{2}{c}{ Total } \\
Estado Civil & N & \% & N & $\%$ & N & $\%$ \\
\hline Casado* & 17 & 73,9 & 13 & 40,6 & 30 & 54,5 \\
Solteiro & 06 & 26,1 & 19 & 59,4 & 25 & 45,5 \\
\hline Total & $\mathbf{2 3}$ & $\mathbf{1 0 0 , 0}$ & $\mathbf{3 2}$ & $\mathbf{1 0 0 , 0}$ & $\mathbf{5 5}$ & $\mathbf{1 0 0 , 0}$ \\
\hline
\end{tabular}

*estatisticamente significativa 
Os dados para o sexo masculino são apresentados na tabela 11.

Tabela 11: Distribuição dos trabalhadores do sexo masculino (n e \%) segundo a presença/ausência de fadiga e o estado civil.

\begin{tabular}{l|cccccc}
\hline \multirow{2}{*}{ Fadiga } & \multicolumn{2}{|c}{ Com Fadiga } & \multicolumn{2}{c}{ Sem Fadiga } & \multicolumn{2}{c}{ Total } \\
Estado Civil & N & $\%$ & N & $\%$ & N & $\%$ \\
\hline Casado & 28 & 53,8 & 37 & 40,2 & 65 & 45,1 \\
Solteiro & 24 & 46,2 & 55 & 59,8 & 79 & 54,9 \\
\hline Total & 52 & 100,0 & 92 & 100,0 & 144 & 100,0 \\
\hline
\end{tabular}

Como pode ser observado na tabela 11, a porcentagem de trabalhadores fadigados do sexo masculino foi de $(53,8 \%, 28)$ para os casados e $(46,2 \%, 24)$ para os solteiros, diferença não significativa $\left(\chi^{2}=\right.$ 2,$49 ; p=0,11$ ).

Quando se analisa a cronicidade da fadiga levando em conta o item do questionário referente ao tempo de duração do cansaço, pode ser observado que a taxa de prevalência de "fadiga crônica" (permanência dos sintomas por mais de 6 meses), dentre aqueles com fadiga profunda foi $7,0 \%$ (14). Para os homens esta prevalência foi de $5,5 \%$ (8) e para as mulheres foi de $10,9 \%$ (6).

A taxa de fadiga profunda encontrada quando a análise foi feita por setor pode ser observada na tabela 12.

Tabela 12: Distribuição dos trabalhadores ( $\mathrm{n}$ e \%) por setores pesquisados segundo a presença / ausência de fadiga.

\begin{tabular}{l|ccccccc}
\hline \multirow{2}{*}{ Fadiga } & \multicolumn{3}{|c}{ Setorabamento } & \multicolumn{2}{c}{ Telem. Ativo } & \multicolumn{2}{c}{ Total } \\
& N & $\%$ & N & $\%$ & N & $\%$ \\
\hline Com Fadiga & 58 & 36,3 & 17 & 42,5 & 75 & 37,5 \\
Sem Fadiga & 102 & 63,7 & 23 & 57,5 & 125 & 62,5 \\
\hline Total & 160 & 100,0 & 40 & 100,0 & 200 & 100,0 \\
\hline
\end{tabular}


A porcentagem de trabalhadores que apresentam fadiga é maior no TA do que no SA, mas essa diferença não é estatisticamente significativa ( $\chi^{2}$ $=0,53 ; p=0,46$ ).

O quadro 6 mostra a distribuição das respostas aos sintomas físicos e mentais separados por setor de trabalho e com a presença ou ausência de fadiga.

Quadro 6: Comparação da freqüência de respostas dadas pelos trabalhadores dos dois setores analisados, nas categorias "mais que o habitual" e "muito mais que o habitual" para as subescalas separadas em sintomas físicos, mentais e dor muscular.

\begin{tabular}{|c|c|c|c|c|}
\hline SINTOMAS & $\begin{array}{l}\text { SA } \\
n(\%)^{*}\end{array}$ & $\begin{array}{l}\text { TA } \\
\mathrm{n}(\%)^{*}\end{array}$ & $\begin{array}{l}\text { SA c/ Fadiga } \\
\mathrm{n}(\%)^{* *}\end{array}$ & $\begin{array}{l}\text { TA c/ Fadiga } \\
n(\%)^{* *}\end{array}$ \\
\hline \multicolumn{5}{|l|}{ Físicos } \\
\hline Sentindo cansado & $59(36,9)$ & $18(45,0)$ & $44(75,9)$ & $16(94,1)$ \\
\hline Mais descanso & $73(45,6)$ & $19(47,6)$ & $41(70,7)$ & $14(82,4)$ \\
\hline Sono ou sonolento & $62(38,8)$ & $16(40,0)$ & $43(74,1)$ & $13(76,5)$ \\
\hline $\begin{array}{l}\text { Problemas em iniciar } \\
\text { os afazeres }\end{array}$ & $16(10,9)$ & $4(10,0)$ & $14(24,1)$ & $4(23,5)$ \\
\hline Falta de energia & $38(23,8)$ & $13(32,5)$ & $33(56,9)$ & $13(76,5)$ \\
\hline Fraqueza em músculos & $50(31,1)$ & $9(22,5)$ & $39(67,2)$ & $9(52,9)$ \\
\hline Se sentido fraco & $30(18,8)$ & $5(12,5)$ & $29(50,0)$ & $5 \quad(29,4)$ \\
\hline \multicolumn{5}{|l|}{ Mentais } \\
\hline Dific.de concentração & $31(19,4)$ & $9(22,5)$ & $25(43,1)$ & $9(52,9)$ \\
\hline $\begin{array}{l}\text { Sente a língua enrolar } \\
\text { ou pesada quando fala }\end{array}$ & $16(11,9)$ & $6(15,0)$ & $13(22,4)$ & $5(29,4)$ \\
\hline $\begin{array}{l}\text { Dificuldade de } \\
\text { encontrar a palavra } \\
\text { certa }\end{array}$ & $29(18,1)$ & $5(12,5)$ & $25(43,1)$ & $3(17,6)$ \\
\hline $\begin{array}{l}\text { Dificuldade de } \\
\text { memorização }\end{array}$ & $32(20,0)$ & $11(27,5)$ & $25(43,1)$ & $8(47,1)$ \\
\hline \multicolumn{5}{|l|}{ Dor Muscular } \\
\hline Músculos doem & $41(25,6)$ & $13(32,5)$ & $32(55,2)$ & $9(52,9)$ \\
\hline $\begin{array}{l}\text { Músculos doem pós } \\
\text { exercícios }\end{array}$ & $49(30,1)$ & $9(22,5)$ & $32(55,2)$ & $6(35,3)$ \\
\hline & & & & \\
\hline
\end{tabular}

* porcentagem em relação ao total de trabalhadores do setor ( $\mathrm{SA}, \mathrm{N}=160$ e STA, N $=40$ ).

** porcentagem em relação ao total de trabalhadores com fadiga ( $\mathrm{SA}, \mathrm{N}=58$ e STA, $\mathrm{N}=17$ ). 


\subsubsection{Análise dos Motivos da Fadiga ou Cansaço}

A Escala de Fadiga de Chalder possui uma última questão aberta sobre as razões de se estar com fadiga no momento de responder ao questionário. Esta questão, por ser aberta, necessita de uma análise qualitativa. Para proceder a essa análise, consideramos as causas da fadiga generalizada expostas por Grandjean (1988) e Bartley e Chute (1947), bem como os fatores de exposição no trabalho geralmente adotados pelos pesquisadores na área da ergonomia. Utilizamos também os inventários das condições de trabalho de McAtamney e Corlett (1992) do Institute for Occupational Ergonomics, University of Nothingham e de Ahonen et al (1989) da Ergonomics Section Finnish Institute of Occupational Health, além, é claro, dos sintomas relacionados à fadiga definidos por Chalder et al (1993).

As respostas a esta pergunta mostraram a diversidade de fatores que estão relacionados à sensação de fadiga $e$, assim, algumas das respostas não foram passiveis de classificação dentro dos parâmetros adotados. $A$ divisão das respostas pelos itens e as respostas sem classificação são apresentadas no Quadro 7.

No total dos trabalhadores, $87 \%$ (174) responderam a questão "o que faz você pensar que está cansado? Por favor, tente dar uma razão". Dentre estes, $4,0 \%(7)$ dos trabalhadores deram como resposta "não estar se sentindo cansado" e estes trabalhadores não apresentaram fadiga na análise do indicador de fadiga. $77,6 \%$ (135 dos 174) eram do SA e $22,4 \%$ (39) do STA. Observa-se que apenas 1 trabalhador do setor de STA não referiu as razões que o levam a estar cansado. Pode-se entender que este trabalhador teve a leitura de que se não estivesse cansado não deveria responder a esta pergunta, além dos $2,5 \%$ (1) do STA que respondeu não se sentir cansado. Dentro do SA, considerando o total de trabalhadores no setor, $3,8 \%$ (6) dos trabalhadores responderam não se sentirem cansados.

Algumas respostas foram desdobradas em duas ou três por conterem fatores diversos podendo, assim, serem contadas nas diversas classificações estabelecidas. Por exemplo, quando o trabalhador refere dor 
no corpo e sono. Dor no corpo é classificada no item doenças e dores e sono (sentir sono) aos sintomas de fadiga da Escala de Fadiga de Chalder. Dentre o total de trabalhadores 26 deles não ofereceram uma justificativa de se sentir cansado. Destes 26 trabalhadores apenas 4 apresentaram fadiga estimada pela escala de Fadiga de Chalder.

Quadro 7: Classificação das Respostas à pergunta "o que faz você pensar que está cansado"

\section{Setor de Acabamento (SA)}

Relacionadas a Fatores Organizacionais do Trabalho: ritmo de trabalho acelerado, falta de pausa para descanso, exigência de produção, pressão de chefia, turno e jornada extensa de trabalho, repetitividade de movimentos, relações, comunicações com os colegas.

1. A correria da empresa e a pressão do dia a dia.

2. A correria no trabalho.

3. A carga de horário é um pouco puxada 14 as $22 \mathrm{~h}$ vocé mesmo acaba se...

4. A rotina de nosso trabalho.

5. A rotina do dia a dia na empresa.

6. Devido a correria do serviço e pouco tempo para descansar isto torna-nos estressado.

7.É quando estou trabalhando de segunda ao domingo.

8.Dupla jornada, pouco tempo de descanso.

9. Muito trabalho e pouco repouso.

10. Nada me faz pensar que estou cansado, mas às vezes quando trabalho fazendo muito movimento repetitivo, durante várias horas você se cansa um pouco.

11. O desgaste da semana porque de terça, sexta e sábado são os dias mais puxados aqui na empresa.

12. Por trabalhar muito e pela incerteza da estabilidade no emprego.

13. Todos os dias as mesmas coisas $\theta$ as mesmas tarefas a serem executadas.

14. Trabalho repetitivo, o trabalho $6 \times 1$ folgando apenas aos domingos(assim é quando folgamos)

15. Excesso de trabalho, fora do habitual.

16. Falta de folga.

17. Fazer a mesma coisa sempre.

18. Quando acumula muitas tarefas para exercer.

19. Trabalhando muito.

20. Trabalhar 365 dias para folgar só aos domingos e bem pouco. Por isto o cansaço é muito.

21. Trabalhar seis dias na semana o porque o domingo passa muito rápido.

Relacionadas à tarefa: trabalho fisicamente penoso

1.0 esforço físico gasta nossa energia por isso fico cansado.

2.0 levantamento de peso na máquina e a forma como trabalhamos.

3.Ao mesmo tempo muito esforço físico.

4. Quando acumula muitas tarefas para fazer.

Relacionadas à tarefa: trabalho com exigência de postura estática

1.Pensar em ficar 8:00 horas em pé.

2. Porque trabalho todos os dias em pé pego pacotes pesados, acordo muito cedo para trabalhar e não consigo dormir cedo.

3. Muito tempo em pé e o maior motivo de cansaço.

Relacionadas à tarefa:

trabalho mentalmente penoso e trabalho com exigência de atenção e concentração (sem referência)

Relacionadas ao clima: calor 
1. O calor frequente no setor de trabalho.

Relacionadas ao clima:

Frio, Ventilação, Exaustão, Arranjo físico (Lay-out), Equipamentos e Ferramentas de Trabalho, Mobiliário (sem referência).

Relacionadas à iluminação: intensidade da iluminação, qualidade da iluminação (sem referências).

Relacionadas ao ruído: tipo de ruído, intensidade do ruído, tempo de exposição

1. O barulho faz as vezes vocé ficar estressado.

Relacionadas a causas psíquicas, responsabilidade, ansiedade ou conflitos: responsabilidades com o trabalho (sem referências).

Relacionadas a causas psíquicas, responsabilidade, ansiedade ou conflitos: responsabilidades com a vida pessoal - familia, sobrevivência,

1. acredito que isto é mais mental ou seja desanimado com a vida. Todos nós temos capacidade de superarmos todos os obstáculos da vida.

2.As dividas.

3.Acho que as preocupações, a rotina semanal etc.

4. Devido as minhas necessidades tenho muitas coisas a fazer em meu lar,tenho trés irmãos desempregados, muita preocupação.

5. Muitos problemas familiar querendo ajudar mas não tenho condições para ajudar.

6. Quando estou com problemas particulares.

7.A correria do dia a dia.

8. Acho que as preocupações, a rotina semanal etc.

9.0 caso de vocé trabalhar e estar sempre endividado e o baixo salário $\theta$ os problemas conjugais isto da um pouco de desanimo.

10. Sinto cansado por algumas indisposições e dívidas.

Relacionadas a causas psíquicas, responsabilidade, ansiedade ou conflitos:

conflitos no trabalho e na vida pessoal

1.A parte familiar. a parte profissional.

2.A parte psicológica tem grande influencia no meu cansaço físico.o dia a dia, muitas vezes o comportamento das pessoas que estão ao nosso redor.

3.Problemas pessoais.

Relacionadas a doenças e dores: dores musculares

1.Dores musculares, estresse, depressáo, enxaqueca, olheiras pálpebras.

2.Dores musculares devido a repetição de movimentos.

3.Dores musculares após o senviço,principalmente depois de revista .......por ser muito pesado os fardos dos cadernos.

4.Dor muscular.

5.Dores musculares.

6.Dores musculares.

Relacionadas a doenças e dores: dores diversas

1.Ando meio estressado e acaba afetando minha mente e meus músculos.

2.Dores no corpo.

3.Dores pelo corpo.

4. Dores por todo o corpo.

5.Algumas dores.

6.Sentir dores nas pernas, vontade de ficar em casa e não ir ao trabalho, gostaria de ter mais tempo para o lazer pois para mim é mais mental do que físico.

7. Quando eu estou menstruada sinto fraqueza nas pernas pois sinto muitas colicas por causa de um mioma.

8.Sinto dores quando vou repassar.

Relacionadas à alimentação: qualidade da alimentação, quantidade disponivel de alimento (sem referências) 
Sintomas Referidos sobre a Fadiga (Chalder 1993): cansaço

1.Em relação ao serviço o cansaço é normal. Eu senti muito cansaço quando a minha irmã teve neném, eu tive que ajudátla no serviço, eu sentia cansaço além do normal, devido a este motivo.

2. Eu me sinto cansada porque eu trabalho fora, trabalho muito em casa,e estudo.

3. Eu só me sinto cansada quando faço muito movimento repetitivo e dói meus braços porque eu tenho tendinite.

4. Quando eu saio fim de semana já saio pensando que estarei cansado no outro dia.

5.0 que faz pensar que estou cansado é quando não descanso direito.

Sintomas Referidos sobre a Fadiga (Chalder 1993): necessidade de mais descanso

1.A falta de repouso devido o estágio das $14: 50$ as $18: 30$ e a faculdado das 19 às $23 \mathrm{~h}$ mais 0 serviço de 6 as 14 h. Poucas horas de repouso, mais ou menos 4:30 horas.

Sintomas Referidos sobre a Fadiga (Chalder 1993): se sentir com sono ou sonolência

1.Sonoléncia.

2.Sinto sono.

3.Sonolência.

4.A sonolência.

5. Sono.

6. Quando sinto o corpo pesado com sono e sem a mesma agilidade de desenvolver minha função.

7.A maioria das vezes e porque não dormi bem a noite.

8. As vezes acho que o fato de que levanto cedo com o passar do dia.

9.As vezes durmo muito pouco e cuido das crianças e venho para o trabalho.

10.Ás vezes um pouco de sono, ou seja, quando acontece de dormir um pouco tarde.

11. Deito tarde e levanto bem cedo e ajudo meus irmãos no trabalho deles até dar a hora de vir para o meu trabalho.

12. Devido ao pouco tempo de horas dormido já que acordo cedo todos os dias para ir a escola e fico o dia todo acordado.

13. Dormir pouco.

14. Dormir pouco faz pensar que estou cansado.

15.Acordar as 04:40 am, trabalhar, estudar e dormir mais o menos às 00:00 horas

16. Muito sono.Durmo apenas 4:30 por noite.

17.Por mais que eu durma (entre 8 a 10 horas diárias) sinto-me com sono durante o dia.

18. Quando abre a boca demais fica com muito sono até mesmo quando esta descansando.

19. Poucas horas de sono.

20. Tenho dificuldade de dormir a noite por isto acho que acordo com sono mas só a primeira hora.

21.Poucas horas de sono.

22. Quando durmo $\mathrm{mal}$.

23. Quando estou com muito sono.

24. Acostumando mal se você dorme tarde e acorda cedo vocé acaba se levantando, mas cansada do que já está.

25. Sentir sono mais do que o normal.

26. Talvez seja por estar dormindo tarde.

27. Muito sono.

28. Não consegue dormir

Sintomas Referidos sobre a Fadiga (Chalder 1993): falta de energia

1. Quando estou com falta de energia muscular ou mental.

Sintomas Referidos sobre a Fadiga (Chalder 1993): fraqueza dos músculos 1.Preguiça,moleza nas pernas, dificuldade de começar um trabalho.

Sintomas Referidos sobre a Fadiga (Chalder 1993): sentir fraco

1.Fraqueza no corpo.

2. Moleza no corpo, vontade de dormir.

3.Fraqueza.

4. Quando a gente sente o corpo fraco e dolorido.

Sintomas Referidos sobre a Fadiga (Chalder 1993): dificuldade de concentração

1.Dificuldade de concentração.

2. Para mim no momento é ter um pouco de concentração no meu cérebro. 
Sintomas Referidos sobre a Fadiga (Chalder 1993): lingua enrolada e pesada, dificuldade de encontrar a palavra certa, dificuldade de memorização (sem referências).

Outras Causas: falta de atividade física e lazer

1.Acho que é a falta de atividades diferentes como por exemplo: ginástica, jogar bola

2.Um pouco de sedentarismo ou seja a falta de praticar alguns esporte.

3. Sinto d̀s vezes falta de um tempo para o lazer, tempo para fazer coisas que eu gosto como praticar esportes, ler, passear e etc...

4. Quando eu não estou em exercícios sinto.

5. Bem, há um ano atrás eu fazia muita atividade física, hoje eu parei, daí em diante eu sinto esse cansaço tenho sentido falta de tempo para tirar um lazer, viajar, enfim passear um pouco.

\section{Outras Causas: estresse}

\section{Sentir um pouco de estresse.}

2.Acho que é estresse.

Outras Causas: muito trabalho

1. Muito trabalho e pouco repouso.

2. Muito trabalho.

3.É que eu trabalho em outra empresa pela manha no horário de 6 as 12 então a tarde a gente sente um pouco de cansaço

Outras Causas: desânimo

1.0 corpo fica um pouco tenso, parece que fica pesado, fica um pouco sem disposição para realizar as tarefas, $\theta$ um pouco de dor de cabeça.

2. Falta de vontade e objetivo. Exemplo: trabalho neste emprego porque preciso.

3. Falta de disposição.

4. O que faz me ter esse pensamento são certos momentos em que estou fora do meu expediente de trabalho e não tenho vontade de fazer nada.

4.Desanimo.

5.Indisposição.

6. Porque me sinto muito indisposta para fazer as minhas tarefas de costume e preocupação e fadiga do dia a dia.

\section{Não sente cansado}

1. Nada me faz pensar que estou cansado.

2.Eu não me sinto cansado.

3.não porque eu gosto, etc.

4. Nada. Porque sou feliz.

5. Não me sinto cansado.

6. No momento nunca me senti cansado sempre na ativa.

\section{Sem Classificação:}

1. Mal estar, mau humor.

2. Na hora em que eu me levanto de manha da cama, meu corpo fica pesado, a cabeça dói, a impressão que dá é que eu num dormi.

3.O trabalho na empresa e serviço doméstico.

4. Quando eu demoro fazer o senviço de casa ou quando vou para a cama antes da hora habitual.

5. A falta de vontade de cada um durante as atividades.

6. Quando eu penso que não realizei o meu trabalho de forma objetiva nos dias mais sofridos.

7. Se estou "cansado" é porque quebrei a rotina, o corpo cansa, dá sono mas a mente alivia.

8. Só me sinto muito cansada quando fico muito preocupada, com um problema que não consigo resolvế-10. muito obrigado.

9. Trabalho bem puxado,época de fim de ano na escola e muito trabalho para entregar.

10. Tudo que acontece ao nosso redor.

11. É que de um tempo para cá estou ficando doente mais facilmente, estes resfriados estão mais frequentes, estou com a resisténcia do corpo fraca.

12. O fato de sentir o corpo pesado, estar procurando sempre um lugar para encostar.

13. As mudanças do horário de verão. o turno da tarde muda nosso fuso horário natural.

14. É estar parado no lugar de senviço sem fazer nada.

15. Fico com minha fisionomia abatida. Quero sempre deitar para tirar um cochilo. 
16. Fico fora de sintonia não consigo me sintonizar muito bem.

17. Inicialmente, vai desde a minha postura quanto a minha paciência.

18. Muitas vezes o cansaço não esta apenas no corpo e sim na mente e nos toma mais cansado devido alguns problemas.

19. No meu caso acho que minha idade ajuda me sentir cansado.

20. No momento em que o ônibus para em frente a empresa e principalmente quando chego no setor de trabalho, e o dia está muito abafado.

21. O dia a dia de ter que trabalhar no período da tarde $\theta$ os problemas do dia a dia.

22. Pensar que o meu futuro pode ser igual ao presente.

23. Sinto uma aceleração dos batimentos cardíacos $\theta$ tenho que fazer mais esforço para realizar tarefas normais do dia a dia.

24. A semana é muito cansativa.

25. Me levanto muito cedo para vir trabalhar: 3 horas da manhã.

25. Falta de paciência.

30. Imitar-se facilmente.

\section{Setor de Telemarketing Ativo (STA)}

Relacionadas à fatores organizacionais: ritmo de trabalho acelerado, falta de pausa para descanso, exigência de produção, pressão de chefia, turno e jornada extensa de trabalho, repetitividade de movimentos, relações, comunicações com os colegas

1.Exercendo o mesmo movimento dianiamente.

2.Em determinadas semanas acúmulo de atividades.

3. Muitas atividades desenvolvidas no transcorrer do dia.

\section{Relacionadas a tarefa:}

1. Toda vez que eu tenho uma tarefa longa pela frente o cansaço chega primeiro.

Relacionadas a tarefa: trabalho fisicamente penoso (sem referências)

Relacionadas a tarefa: trabalho mentalmente penoso

1. Quando tenho muito excesso de trabalho com a minha mente.

Relacionadas a tarefa: trabalho com exigência de postura estática, trabalho com exigência de atenção e concentração (sem referências)

Relacionadas ao ambiente: Arranjo fisico (lay-out), equipamentos e ferramentas de trabalho, mobiliário (sem referências)

Relacionadas ao clima: calor, frio, ventilação, exaustão (sem referências)

Relacionadas à iluminação: intensidade da iluminação, qualidade da iluminação (sem referências)

Relacionadas ao ruído: tipo de ruído, intensidade do ruído, tempo de exposição (sem referências)

Relacionadas a causas psíquicas, responsabilidade, ansiedade ou conflitos

1.0 excesso de responsabilidade.

Relacionadas a causas psiquicas, responsabilidade, ansiedade ou conflitos: responsabilidades com o trabalho (sem referências)

Relacionadas a causas psíquicas, responsabilidade, ansiedade ou conflitos:

responsabilidades com a vida pessoal - familia, sobrevivência,

1. Excesso de afazeres e preocupação com responsabilidade financeira devido justamente a falta necessária de renda para quitar as despesas básicas.

2. Excesso de atividades e responsabilidades (casa,filhos, empresa e faculdade). Não sobra tempo para um relaxamento, um tempo só meu.

3. Muito trabalho. Conciliar casa, trabalho e estudo.

4. Preocupação com a família, dívidas, relacionamento. Razão talvez não estar sendo bem administrado.

5.Preocupações de rotina 
Relacionadas a causas psíquicas, responsabilidade, ansiedade ou conflitos: conflitos no trabalho e na vida pessoal (sem referências)

Relacionadas a doenças e dores: dores musculares

1.Pensar que estou cansada quando o meu trapézio dói ou quando a vontade de deitar é enorme.

Relacionadas a doenças e dores: dores diversas

1.Dores no corpo.

2.Dores no corpo.

3.Só fico cansado quando estou com muita dor de cabeça.

4. Tenho dor no corpo.

Relacionadas à alimentação: qualidade da alimentação, quantidade disponivel de alimento (sem referências)

Sintomas Referidos sobre a Fadiga (Chalder 1993): cansaço (sem referências)

Sintomas Referidos sobre a Fadiga (Chalder 1993): sonolência

1.Sono.

2.Durmo tarde $\theta$ acordo cedo.

3.Durmo muito pouco, mas estou contente porque estou terminando o meu estudo que tanto sonhei.

4.Sono.

5. Quando durmo mal eu tenho insônia faz com que meu corpo fique cansado .

6. Quando sinto muito sono e não consigo me concentrar.

7. Quando durmo mal o corpo fica cansado, quando trabalho muito

8.Sono.

Sintomas Referidos sobre a Fadiga (Chalder 1993): necessidade de mais descanso (sem referências)

Sintomas Referidos sobre a Fadiga (Chalder 1993): falta de energia

1. Falta de energia.

2.Às vezes a falta de energia e motivação pode ser indício de cansaço e às vezes me sinto assim, fora o próprio cansaço físico.

Sintomas Referidos sobre a Fadiga (Chalder 1993): fraqueza dos músculos, sentir fraco (sem referências)

Sintomas Referidos sobre a Fadiga (Chalder 1993): dificuldade de concentração 1. Falta de concentração.

Sintomas Referidos sobre a Fadiga (Chalder 1993): língua enrolada e pesada, dificuldade de encontrar a palavra certa, dificuldade de memorização (sem referências)

Outras Causas: falta de atividade física e lazer

1.somente quando não faço exercício físico.

Outras Causas: estresse

1.0 estresse do dia a dia.

Outras Causas: muito trabalho

1.Eu me sinto cansada porque eu trabalho fora,trabalho muito em casa,e estudo.

Outras Causas: desânimo

1.Desanimada, sem vontade de levantar da cama.

2.Não ter ânimo para os afazeres que exigem movimentos físicos e quando saio do serviço as vezes me sinto acéfalo.

Não sente cansado

1. Não me sinto cansado 


\section{Sem Classificação}

1.Pesadas, cáimbras, dificuldade de raciocínio, fadiga mental, suor frio, etc., etc., etc...

2. Final de ano (estudo, provas).

3.Meu cérebro fica a mil, sinto-me acelerada pois fico confusa, com a mente cansada, não consigo produzir, giro, giro, e não faço nada! Um horror!

4.Não ter nada interessante para fazer,me deixa desmotivado cansado.

5.0 ánimo.

6.Por estar no final de ano já faz 1 ano que sai de férias, aulas à noite na faculdade que também interfere e a preocupação que é um cansaço mental que interfere muito no físico.

7.Quando estou com a capa pesada com a mente bagunçada (embaralhada).

8.Da semana "terça e sábado",fico angustiado.

9. Quando já está para completar 12 meses trabalhando sem as famosas férias.

10. Quando não consigo cumprir as minhas tarefas.

11.Quando sei da minha obrigação em efetuar uma tarefa e fazer somente o que é necessário.

12. Quando sinto que estou sem capacidade de pensar da mesma maneira ou com a musculatura do corpo tensa.

13. Sinto um pouco de cansaço por ter uma rotina muito agitada, mas minha recuperação é muito rápida.

14. Sem paciência. estou fazendo terapia com psicanalista e tomando florais. Passei por uma perda muito grande com o falecimento de meu bebê recém nascido em 07/2000.

15. Falta de vontade em muitas coisas como passeios, compras.

16. Ter que acordar mais cedo do que era habitual.

17. Correr atrás do estágio para pegar o diploma.

\section{A análise quantitativa dessas respostas segundo a classificação utilizada é apresentada no quadro 8.}


Quadro 8 - Distribuição das respostas à pergunta "o que faz você pensar que está cansado? Por favor, tente dar uma razão", segundo a classificação de causas adotada.

\begin{tabular}{|c|c|c|}
\hline $\begin{array}{l}\text { Setor de Trabalho } \\
\text { Causas }\end{array}$ & Acabamento & Telem. Ativo \\
\hline Organizacionais do trabalho & 28 & 5 \\
\hline O ambiente, clima, luz e ruído & 2 & - \\
\hline Causas psíquicas, responsabilidade, ansiedade ou conflitos & 13 & 6 \\
\hline Doenças e dores & 14 & 5 \\
\hline Alimentação & -- & - \\
\hline \multicolumn{3}{|l|}{ Sintomas referidos sobre a fadiga } \\
\hline Se sentir cansado & 5 & - \\
\hline Necessidade de mais descanso & 1 & - \\
\hline Se sentir com sono ou sonolência & 28 & 8 \\
\hline Problemas para iniciar os afazeres & -- & - \\
\hline Falta de energia & 1 & 2 \\
\hline Fraqueza nos músculos & 1 & - \\
\hline Se sentir fraco & 4 & -- \\
\hline Dificuldade de concentração & 2 & 1 \\
\hline Língua enrolada e pesada & - & - \\
\hline Dificuldade de encontrar a palavra certa & - & - \\
\hline Dificuldade de memorização & - & - \\
\hline \multicolumn{3}{|l|}{ Outras causas } \\
\hline Falta de atividade física e lazer & 5 & 1 \\
\hline Estresse & 2 & 1 \\
\hline Muito trabalho (puxado) & 3 & 1 \\
\hline Desânimo/Indisposição & 7 & 2 \\
\hline Não sente cansado & 6 & 1 \\
\hline
\end{tabular}

O quadro 8 mostra que no SA houve um maior número de respostas referentes a fatores organizacionais do trabalho, sono e sonolência, dores, doenças e causas psíquicas, responsabilidades, ansiedade e conflitos. 
As respostas referentes à organização do trabalho foram emitidas em relação ao excesso de trabalho, a jornada de trabalho, a repetitividade no trabalho, a folga, a exigência de desenvolver esforço físico. Para o AS, as respostas que não se enquadraram em uma classificação somaram 27.

Quanto ao STA, o número de respostas sobre "se sentir cansado" recaiu sobre os fatores referentes ao sono e a sonolência e as causas psíquicas, responsabilidades, ansiedade e conflitos.

As respostas referentes à organização do trabalho foram emitidas em relação à tarefa e a repetitividade. Para o STA, as respostas que não se enquadraram em uma classificação somaram 15.

Em algumas falas o motivo dado para o cansaço tem uma justificativa que leva a uma objetiva identificação da causa. Dentre as respostas apenas em uma foi utilizado o termo fadiga. A questão da fraqueza do corpo, cansaço, sonolência e sono durante o trabalho, o esforço físico, o calor, estão relacionados ao aparecimento da fadiga ou são sintomas desta.

Em outras falas pode ser notado o caráter complexo dos motivos do cansaço. Alguns trabalhadores relacionam o cansaço a fatores individuais. Outros ainda se referem à falta de atividade física. 


\subsection{Percepção do Estado de Fadiga Através de Entrevistas Semi- Estruturadas: uma Abordagem Qualitativa}

Dos 23 trabalhadores entrevistados 15 eram mulheres e 8 eram homens. Se separados por setor obteve-se que dos 14 trabalhadores do TA 10 eram mulheres e 4 eram homens, enquanto que no SA 5 eram mulheres e 4 eram homens. Quanto à idade, mais da metade dos trabalhadores entrevistados tinham entre 19 e 30 anos (14,60,9\%). Dos trabalhadores restante, 3 estavam com idade entre 30 e 35 anos e 6 tinham idade acima de 35 anos. Os trabalhadores com idade acima de 40 anos eram 3 e estavam no SA. Para o STA a maior idade foi de 37 anos.

O tempo de trabalho dos entrevistados na empresa está concentrado no intervalo de tempo antes de cinco anos para o STA e acima de 5 anos para o SA. A distribuição dos trabalhadores no tempo na função em menos de 3 anos foi de 9 trabalhadores para o STA e 3 para o SA.

$\mathrm{Na}$ interpretação do discurso, através de ouvir e ler as entrevistas, foi possivel detectar que os trabalhadores se referiam com freqüência à situação de cansaço verbalizando variações da palavra tais como cansativo, cansada (o), cansa, cansar, descansar e a palavra cansaço propriamente dita. Associadas a estas palavras, na maioria das vezes, estavam as palavras desânimo, sem ânimo, irritado (irritar), agoniado, desmotivado, rotina, estresse, dentre outras. Todas presentes em um contexto de descrição do trabalho, de como se sentia tanto no trabalho como fora dele.

Assim, pautada na conceituação de fadiga desenvolvida pelos pesquisadores do século $X I X, X X$ e início deste século, dirigimos a análise das entrevistas considerando a fadiga como uma sensação de cansaço. A base desta conduta tem como referência autores como Holding (1984) que afirma ser a fadiga uma resposta generalizada ao estresse sobre um periodo no tempo; Borg (2000) que aponta a fadiga como um estado que poderia ser chamado de "sonolência" ou alto nível de cansaço ou exaustão; Cameron (1973) que considera que os efeitos crônicos da fadiga podem ser caracteristicamente encontrados na sensação subjetiva de lassidão e cansaço; e Grandjean (1979) que afirma que no estado de fadiga fica a 
sensação subjetiva de cansaço e nas definições da OMS, através da CID Décima revisão, que classifica mal estar, fadiga (R53), como cansaço.

$\mathrm{Na}$ experiência do dia a dia a questão da fadiga para os trabalhadores foi expressa por uma sensação de cansaço, mesmo porque o termo fadiga não parece fazer parte do seu repertório verbal. $E$ o que os trabalhadores referem são seus sinais, sintomas e a relação destes com a vivência no trabalho e na vida. Partindo destas premissas, as leituras e análise do material obtido nas entrevistas foram realizadas no intuito de detectar, no discurso dos trabalhadores, as falas que se relacionavam com a sensação de cansaço ou a percepção da existência de uma situação que levou a se sentir cansado: Os discursos semelhantes foram agrupados sob os seguintes temas: (1) fatores associados à determinação da fadiga; (2) características individuais; (3) identificação da situação problema; (4) expressão da fadiga; (5) conceituação da fadiga e (6) estratégias de enfrentamento da fadiga. Nem todos os trabalhadores abordaram todos os temas, o que consideramos um fato esperado quando se trata de uma entrevista semi-estruturada.

A descrição do discurso foi realizada separando os 23 trabalhadores em dois grupos. Estes dois grupos se originaram da aplicação da Escala de Fadiga de Chalder onde se detectou a ocorrência da fadiga dos trabalhadores entrevistados. Consultando-se os dados da Escala de Fadiga de Chalder, obteve-se que 8 trabalhadores, dos 23 , apresentavam fadiga profunda e 15 não apresentavam. Dos trabalhadores que apresentavam fadiga, 2 eram homens e 6 eram mulheres e quanto ao tempo de trabalho na função 2 trabalhadores tinham 5 anos e os 6 restantes tinham 2 anos. A abordagem dos temas por indivíduo entrevistado, contendo as expressõeschave e as idéias centrais, é apresentada nos Anexos IV (trabalhadores sem fadiga) e V (trabalhadores com fadiga).

Dentre os trabalhadores que não apresentaram fadiga, 4 estavam na função a menos de 1 ano; 3 trabalhadores com este tempo em 2 anos; 2 trabalhadores com 3 anos; 2 trabalhadores com 5 anos; 1 trabalhador não respondeu a esta questão na Escala de Fadiga e os 3 restantes tinham 8 , 
16 e 22 anos na função. Em relação ao sexo, contamos com 5 homens e 10 mulheres.

A decisão de uma descrição do discurso separada em dois grupos teve como objetivo procurar compreender o fenômeno fadiga para quem apresentou fadiga profunda na escala e para quem não apresentou, ou seja, as semelhanças e diferenças no discurso dos dois grupos.

\subsubsection{Definição dos Temas para a Descrição do Discurso}

\section{(1) Fatores Associados à Determinação da Fadiga}

Embora a busca de fatores determinantes para a ocorrência de fadiga entre os trabalhadores não seja o objeto desta tese, os trabalhadores discursaram sobre questões relacionadas à determinação da ocorrência de fadiga com certa freqüência. $O$ discurso dos trabalhadores neste tema não foi relacionado diretamente à fadiga, ou cansaço, mas indicam o tipo de trabalho desenvolvido no dia a dia e mostram a vivência de que este trabalho cansa porque é pesado, com forte exigência física e/ou mental, etc. Entendemos que a compreensão da situação contextual onde ocorre a fadiga, tanto no trabalho como fora dele, é um fator fundamental que adiciona conhecimentos quando se quer entender o estado da pessoa fatigada. Neste sentido, este foi selecionado como um tema importante a ser considerado na análise descritiva. Entendemos também que a presença do tema está relacionada às perguntas introdutórias da entrevista, ou seja, as perguntas: "como se sente no trabalho" e "como é o seu trabalho".

Este tema em especial foi separado em dois discursos coletivos, um para os trabalhadores do STA e um para os do SA, porque os fatores determinantes para o aparecimento de fadiga, presentes no ambiente de trabalho, mostram diferenciação pela própria natureza da atividade desenvolvida, conforme já apresentado na observação dos dois ambientes de trabalho. 


\section{(2) Caracteristicas Individuais}

Para a compreensão do quadro de fadiga é indicado que se conheça as características individuais, pois estas têm um papel importante uma vez que várias indicações de autores apontam a fadiga como uma questão subjetiva. Cameron (1973) indica esta questão subjetiva como reações individuais ao estresse ao longo do tempo e Grandjean (1988) entende a fadiga como conseqüência de uma soma dos fatores de exigência sobre as pessoas. Portanto, entender como as pessoas se comportam diante de um trabalho contribui para investigar como a pessoa se expressa em termos de ter ou não fadiga. As características do indivíduo podem estar indicando como ele se comporta diante da situação colocada a sua frente, no contexto do trabalho ou fora dele. É também um relato de como os indivíduos se vêem no trabalho e na sua vida diária. Podemos Justificar a escolha do tema até mesmo com a fala dos próprios trabalhadores: "todo mundo acha alguma coisa".

Para este tema e para os seguintes não se fez necessário a divisão por setor de trabalho porque as características individuais, identificação da situação problema; expressão da fadiga; conceituação da fadiga e estratégias de enfrentamento da fadiga não dependem do ambiente de trabalho para ser descrita ou mesmo entendida.

\section{(3) Identificação da Situação Problema}

Neste tema foram incluídos os discursos em que os trabalhadores apontaram a relação entre os fatores da determinação da fadiga com a situação concreta existente, ou seja, entenderam que existe um problema gerado pelos fatores determinantes. $O$ problema tanto foi apontado para a situação individual como para o coletivo. Definimos este tema como uma questão relevante, pois não basta só saber que uma situação está sendo vivenciada, mas sim entender que esta situação é um problema e que se deve pensar em uma forma de solucioná-lo. 


\section{(4) Expressão da Fadiga}

Neste tema a abordagem é de como as pessoas percebem, em si e no coletivo, a manifestação da fadiga através dos sinais e sintomas. Como é que as pessoas sentem o problema do cansaço/fadiga. Dos 8 trabalhadores que apresentaram fadiga pela Escala de Fadiga de Chalder, 7 expressaram suas sensações de cansaço/fadiga. A percepção da manifestação destes sinais/sintomas está relacionada ao discurso sobre o cansaço, desânimo, desmotivação, falta de energia, seguindo as classificações dos achados na literatura que definem sinais e sintomas comumente apresentados para se considerar um indivíduo como tendo fadiga, como por exemplo, os sinais e sintomas da Escala de Fadiga de Chalder, das referências de Grandjean (1988), de Holding (1984) e Cameron (1973). As expressões que apareceram nos discursos às vezes não eram diretas, objetivas, mas estavam se referindo a estes componentes. Lembramos que se agregaram neste tema sintomas que apareceram no discurso.

\section{(5) Definição de Fadiga}

É importante comentar que dentro deste tema só um trabalhador conceituou a fadiga de maneira explícita, mas consideramos coerente apresentar este discurso.

\section{(6) Estratégias de Enfrentamento da Fadiga}

Durante a leitura dos discursos detectamos questōes interessantes de como os individuos entrevistados tinham determinados comportamentos para se defender das situações impostas pela natureza do trabalho. É importante visualizar que o comportamento das pessoas diante das situações vividas depende das estratégias elaboradas para enfrentá-las. Como a situação de uma pessoa fatigada passa pela questão subjetiva é importante conhecer como as estratégias de enfrentamento são elaboradas para continuar vivendo determinadas situações presentes no dia a dia do trabalho. Se a sensação de repugnância presente no quadro de fadiga, 
segundo Grandjean (1988), é várias vezes de marcada natureza emocional, então o comportamento defensivo que as pessoas apresentam no enfrentamento desta situação contextual pode nos oferecer um caminho para entender a sensação de aversão ao esforço, sensação de repugnância, - lidar com a situação emocional como ansiedade, irritação, desespero, raiva, etc.

\subsubsection{Discurso dos Trabalhadores com Fadiga ${ }^{10}$}

\section{(1) Discurso do Sujeito Coletivo do STA sobre o Tema: Fatores Associados à Determinação da Fadiga}

Trabalho com renovação de assinaturas, falar com as pessoas, procurar trazê-las de volta para a assinatura ativa. Isso é constante, durante o dia, o período de 6 horas. E não deixa de ser um desafio. Você precisa ficar "tensionado" com ele, saber o que ele está falando, o que ele prefere, o que está acontecendo, então tem que ter atenção Tem que se esforçar. É um trabalho que exige atenção. $\dot{E}$ um trabalho que exige o seu esforço, você tem que estar atento tem que vender. Exige atenção e responsabilidade, mas não é o fim do mundo. Porque é assim, funciona assim: a gente tem metas e números, quando eu não consigo superar estes números e estas metas eu vou passar os meus limites porque além de ter de procurar o que eu perdi, eu vou ter de fazer o que eu preciso ainda, então assim eu passo um pouco dos meus limites. Eu me pressiono porque eu tenho metas a cumprir. Não é uma coisa fácil, não é mesmo, Hoje em dia ninguém está querendo comprar nada. Quando a gente liga é para estar reacendendo aquela paixão que eles tinham pela revista, aquela coisa, é resgatar eles de alguma forma. Então por isso que a maior parte é não mesmo. A única coisa negativa que eu falo, seria isso mesmo, dessa coisa de quando está difícil a venda, e isso cansar a ponto de trazer um desânimo. Às vezes você fica meio cabisbaixo, em relação a determinados clientes que te atendem super mal. Tem casos que não tem como, eles desligam o telefone, xingam, então, esquecer. Esquece, liga pro outro, e é outro contato, é outra, é outra forma de trabalhar. Tem certas situações que realmente tem clientes

\footnotetext{
${ }^{10}$ Lembramos que os trabalhadores foram classificados com fadiga de acordo com a Escala de Fadiga de Chalder.
} 
que te agridem tanto que você fica com aquilo, assim, na cabeça por vánias semanas. Eu acho, que esquecer, esquecer, você nunca esquece. A pessoa que trata mal você não esquece. Então passa o mês, a gente tem que cumprir aquela meta, então isso deixa um pouco... Meio cansativo. Mas fim de mês é o que cansa um pouco mais. É quando a gente esta um pouco mal, eu estou um pouco mal. Mas dá para estar levando.

E trabalhar pelo salário fixo que a gente recebe que é pequeno, e bem baixo, e com a comissão de tudo aquilo que a gente vende. Então a gente precisa realmente vender o máximo para conseguir tirar um salário que dê para manter as contas, para sobreviver. Ah! A necessidade de números. Eu acho que é uma pressão necessária para o departamento, só que pesada para quem exerce na verdade a função. A nossa sobrevivência acaba saindo muito caro em relação ao nosso esforço. A gente trabalha com uma pressão porque a gente trabalha com vendas, às vezes isso atrapalha porque senão eu não vou ter salário que seja bom pra mim. Mas, é uma coisa de cansar, de você falar, falar, falar e não conseguir. Como todo serviço chega uma hora que você cansa. Então, é essa pressão que às vezes cansa, dessa autopressão, de tanto eu estar fazendo. Está chato, incômodo, então tudo isso. Eu acho que todo mundo dentro de seus limites, todo mundo sofre da mesma pressão e principalmente no final do mês se não foi bom acaba refletindo no bolso que dai é onde pega mais pra todo mundo.

Fiquei afastada uns 3 anos e pouco por tendinite nos braços, no punho, no ombro. Problema a gente tem, não tem solução, não tem cura, fazer o que? Assim, no caso, esses problemas de tendinite é um problema que não tem cura. Então a gente vai levando.

Eu estou passando por um processo de doença, eu estou com apnéia, eu também sinto algum distúrbio durante o sono mais isso é um problema que eu estou trabalhando pra ver se resolvo.

Idéia central: Trata-se de um trabalho realizado sob exigência de atenção e responsabilidade que prevê o cumprimento de metas e depende de fatores externos, no caso, o cliente, com remuneração através de um salário fixo mais a comissão. Ocorre um aumento da carga no final do mês por causa do fechamento das metas. Isso cansa e é um trabalho marcado pelo desânimo, autopressão e esforço, que leva a ultrapassar os limites pessoais. Aparecem 
doenças como apnéia e distúrbios do sono, tendinite em ombro, braços e punho.

\section{(1) Discurso do Sujeito Coletivo do SA sobre o Tema: Fatores Associados à Determinação da Fadiga}

Eu trabalho assim, tem dia que eu não forço muito, mas tem dia que eu forço bastante quando eu vou fazer o acerto de máquina, se estou virando determinado serviço, por exemplo, se estou virando uma revista " $x$ ", vai entrar outra revista, eu tenho que trocar as guilhotinas, fazer reacerto, então é onde eu trabalho mais, mas quando eu pego assim a máquina que já está rodando em determinado serviço eu vou ficar tipo acompanhando ali. Tem a equipe que vai trabalhando, o pessoal na gaveta, na saída, mas quando o pessoal precisa sair, fazer alguma coisa eu fico no lugar deles, assim fica mais "ligth". Mas tem gente que trabalha bem mais que eu, bem mais pesado. Meu trabalho não é tão pesado assim. Mas o problema é estar de pé, que dá essa "canseirinha" nas permas. Eu acho que é a maioria pelo fato do pessoal ficar de pé o dia todo.

Tipo assim, o trabalho é um movimento muito repetitivo. Você fica muito tempo numa posição só. Que nem: a gente trabalha no conserto, de vez em quando vou para a gaveta, para as saídas, serviço dos meninos também faço. Ás vezes eu estou cansada de ficar ali. Eu não fico ali, vou pra outro lugar. O trabalho mesmo não me imita. Como eu falei: aquela coisa todo dia, todo dia, chega uma hora que você não aguenta e aí depois você melhora! Tem certas pessoas que pegam no teu pé por uma coisa, por outra, mas fora isso tudo bem. Porque todo mundo gosta de mandar um pouco, lá dentro, né? Todo mundo quer ficar andando pra lá e pra cá, todo mundo queria ser chefe. Se eu fosse...

Eu gosto, porque não tem outro local para eu trabalhar. Assim, eu me adaptei lá porque eu fiquei um tempo afastada, 3 anos, quando eu voltei eles me colocaram lá.

Idéia central: Trata-se de um trabalho realizado em pé durante toda a extensão da jornada de trabalho e isto acarreta canseira nas pernas. Há a realização de movimentos repetitivos, com diferentes cargas nos dias da 
semana (altos e baixos). É um trabalho que cansa. Há também a forte presença da hierarquia, se valoriza o chefe, que é quem manda.

\section{(2) Discurso do Sujeito Coletivo sobre o Tema: Características Individuais}

Meu trabalho é uma coisa que eu gosto, gosto do que faço, me sinto uma vendedora. Eu gosto de ser vendedora, curto muito isto. Eu já tenho mais prática hoje. Para mim já não fico tão perdida no trabalho, então eu faço um trabalho ao meu modo até o meu limite. Tem dia que não dá pra trabalhar mesmo. Tem dia que a mente não dá. Não tem que trabalhar não! Porque muita gente às vezes faz isso, tem que trabalhar tem que produzir. Só vou até meu limite, mesmo. Hoje eu estou bem eu procuro trabalhar mais, amanhã se eu estou mais ou menos. Claro que não dá para passar do meu limite. Eu respeito o meu corpo, eu respeito a minha situação. Hoje eu tenho uma postura mais rigida comigo. Eu procuro me concentrar mais. Hoje eu me ponho responsabilidade maior. Eu amadureci com certo tempo. Eu amadureci na questão de ter que me responsabilizar mais nesta questão de estar trabalhando, levar mais a sério.

Eu gosto de estar sempre se falando. Meu negócio é humano, eu não gosto muito de máquina. Eu gosto mais de humano, eu prefiro. Eu não nasci para ficar mexendo em máquina atrás de um computador. Lógico que você tem que trabalhar tem que estar atualizado tem que estar bem tecnologicamente, mas eu gosto mais da parte humana.

A gente tem que ser bom. Ser bom é cumprir os objetivos, é estar dentro de todos objetivos passados e também tentar superar isso pra poder realmente vir um salário que dê para ai continuar tocando a sobrevivência da gente. Então esse é o ser bom que todo mundo busca. Eu gosto muito, me sinto bem, amo muito o que eu faço, mesmo que isso me traga cansaço, nem que isso me prejudique. Eu já até estou acostumada a essas dores, esse cansaço físico, já passa a acostumar. Estar acostumada acho que é saber viver. Não tem como você fugir. Uma coisa que já está para você, então, se acostuma. Acho que é bem por aí.

Você lidar com pessoas não é fácil e eu consigo manter a produção da máquina e o pessoal em harmonia.

Eu não gosto muito de rotina, eu gosto de coisas diferentes. Sempre um estar mudando. Eu não tenho muita mania de estar falando, eu guardo pra mim. Eu 
quero uma coisa e se acabar deixando para outro dia, aquilo vai indo, vai indo que eu não consigo esperar, aí eu vou atrás e faço. Então vai indo e você não vai conseguindo, aquilo vai agoniando pór dentro. Eu gosto de trabalhar mesmo assim, mesmo se for dia corrido, ou que nem hoje, um dia sossegado.

Eu não vou me maltratar por causa do problema.

Idéia central: Eu gosto do que faço, mesmo que isso prejudique. São muitas as responsabilidades do trabalho. Nós temos que ser bons no que fazemos. Em geral, sou rígido comigo mesmo, deve-se trabalhar até o limite. Gosto de falar, mas não gosto de rotina. Já estou acostumado a lidar com as dores e cansaço: estar acostumado é saber viver. Não gosto de computador, mas de gente. Se não consigo o almejado vou me tornando "agoniado por dentro".

\section{(3) Discurso do Sujeito Coletivo sobre o Tema: Identificação da Situação Problema}

Final de mês a gente se cansa bastante, eu me canso bastante. Quando estou no mês e não estou bem na campanha e tal, ai eu me sinto super cansada porque eu vou muito atrás e fico muito cansada. Cansada, acho que é os "não" que a gente leva. Levar não, assim, eu me canso de levar não. Mas tem momentos assim que o estresse está muito grande aqui, o dia foi muito cheio, muito carregado, e a gente sai com a cabeça cheia, sai cansado. Eu não consigo pagar as minhas contas e vai transferindo, eu acho que tudo vai fazendo uma transferência para o corpo porque mesmo que você não queira acaba acarretando no mesmo. Você falando, minha casa é uma coisa, meu trabalho, minha vida particular é outra, realmente...mas... É tudo um complemento e o corpo sente cansado, a gente se sente estressado, 0 pessoal comenta sobre o dia a dia, mesmo dentro do departamento, que é estressante. A preocupação, o estresse mental, acaba influenciando no seu descanso. Ah! Fica chato dentro do departamento, e se a gente não cumpri não consegue atingir financeiramente o rendimento para pagar sequer as contas tradicionais.

A gente trabalha também lá digitando, então isso, é da rotina mesmo, não tem como fugir disso. Acho que isso traz alguma coisa para o físico. A rotina de você estar lá, de chegar em casa, só pensa em dormir. Sabe mais por isso, é um lado 
muito cansativo. É assim, sensação de cansaço, eu acho de rotina. Quando está no final de mês, por exemplo, já está terminando, eu acho que eu sinto um alívio, principalmente como eu falei, campánhas, essas coisas que se cumpre, se sente aquele alivio que foi cumprido, tudo, que é aquele trabalho que daquele mês você conseguiu fazer. E não é mais aquela preocupação. Hoje mesmo, final do mês, a gente já fica até aliviado, se sente até melhor o corpo. Durante o meio do mês você fica tensa, você fica com o corpo assim, você sente isso no físico e quando você chega no final parece que sai tudo.

Tem algumas pessoas também que dá problemas de coluna, que a gente trabalha com paletes, abaixa-levanta, abaixa-levanta, dá problema de coluna. Muita gente se afasta por problema de coluna. A gente trabalha de pé o dia inteiro então é uma canseira! Mas eu acho assim uma mentira...eu não falar que todo num trabalho não cansa que realmente cansa. Quando a revista está boa de fazer ela não ajunta muito o serviço, mas quando tem muito você não agüenta e o movimento que você faz, o tempo que você fica parado, cansa o corpo, dói muito o braço.

Qualquer coisinha, aquilo imita né? Acho que isso seria, seria o estresse? Não sei. Acho que o momento em que sinto cansada não teria assim um momento certo. Acho que dependeria do dia. Venho aqui trabalhar porque eu já sei como vai ser. Vai ser aquela rotina. Não vai passar daquilo, no máximo que eu vou trabalhar é aquilo. Se a gente fosse escolher o trabalho, todo mundo ia querer ser chefe. Todo mundo ia querer mandar.

Segunda-feira eu tomei um tombo na máquina. Bati o cotovelo no chão. Eu caí mesmo, quase bati a cabeça no chão. Tava sentindo muita dor no braço, daí eu nem fui no ambulatório, eu fui pra casa, eu não tava nem conseguindo levantar o braço ontem, mas na correria eu sabia que meu braço estava doendo. Eu não estava agüentando de dor, mas naquela correria você vai trabalhando, trabalhando, trabalhando... Daqui a pouco até esqueci do braço. Fui me lembrar do braço à noite quando fui dormir. Quer dizer, meu corpo nem estava preparado, mas a mente estava. Sabia que eu tinha que trabalhar e esqueci a dor e fui trabalhar. Neste jeito que eu encaro: que tem que trabalhar, não importa o estado que você está.

Porque trabalhar triste assim, descontente é a pior coisa, porque trabalhar já é um saco se você vier descontente.

Todo trabalho cansa, lógico. Chega uma hora que bate um tédio, dá uma canseira danada. 
Idéia central: Sou uma pessoa preocupado, com estresse mental. Não consigo pagar as contas por não alcançar rendimento suficiente e isso acaba influenciando no meu cansaço. Os "não" que recebo nos telefonemas e a digitação contínua trazem dificuldades para o físico, para o corpo. Qualquer coisa me irrita, o cansaço depende do dia. Trabalhar em pé é uma canseira, abaixar e levantar traz problemas na coluna e tem-se que esquecer a dor porque a alma (mente) tem que estar preparada.

\section{(4) Discurso do Sujeito Coletivo sobre o tema: Expressão da Fadiga}

Eu me sinto cansada por falar, falar, falar e não conseguir. Então às vezes eu fico um pouco cansada mentalmente. Esse cansaço é um cansaço assim... Então, agora me deixa pensar. Sabe que eu nunca parei para pensar sobre isso! É assim: eu falo, falo, falo e não consigo, ai eu me sinto cansada, não é cansada...Não chega nem a ser cansada... Sinto-me chateada, porque a gente olha para os lados e não está a mesma coisa com as outras pessoas. Sempre um está bem, o outro num está bem e a gente não quer ficar por baixo, quer estar sempre igual às outras pessoas que estão na média. Às vezes eu saio daqui irritada. Tem outros motivos ou pode até ser um motivo do trabalho. Mas tem dias que eu não vendo nada, nada. Estou com problemas na minha casa, não vendo nada e estou super bem. $E$ tem dias que eu estou assim super bem, de repente eu me fecho, fico super chateada e sofro com isso e fico cansada. Às vezes eu chego em casa duas horas da tarde e eu quero dormir, não quero ver nada, eu quero deitar e descansar. Então, assim, depende, depende muito do cansaço. Eu acho que o cansaço depende muito da pessoa, do estado de espírito da pessoa.

Essa autopressão de tanto eu estar fazendo às vezes eu não estou com ânimo nenhum, não estou disposta. Sem ânimo eu encaro assim como sem disposição, sem coragem para estar fazendo aquilo porque não estou tendo um bom retorno daquele que eu gostaria, no sentido de atendimento das pessoas que as vezes a gente liga, liga, liga, liga e nada e liga e nada e aí aquilo vai desanimando, vai desanimando e cansa. Então o gás acaba mesmo. Então às vezes cansa mesmo, cansa, me sinto cansada assim mentalmente, fisicamente também. Então, eu estou assim bem cansada. Assim, de cansaço, de "ah, que saco!". 
Para o corpo a gente sente pesado, aí se eu pudesse não la para o serviço, esse tipo de coisa porque não vislumbra uma melhora em relação a troca de serviço com o salário em troca do que a gente pode almejar um dia a mais na sociedade. É uma cobrança grande, a gente acaba se sentindo bem cansado. A gente geralmente está saudável quando tem corpo e mente saudável. A mente só pode estar saudável quando o corpo está saudável. Então com esse estresse, com esse dia a dia tão comido todas as energias que você não vê como energias boas, incorporando elas e sentindo braços e pemas cansados. Chega no final do dia o cansaço mental faz você não conseguir nem pensar, se sentir meio acéfalo, até em relação ao que você deve fazer. Por exemplo, chegando em casa no final de uma semana estressante você chega sem condições até de conversar porque se sente realmente muito cansado não querendo nem sequer levantar um dedo porque aquilo parece que transferiu para o corpo.

Cansativo! Acho até que isso até reflete no corpo, no dia a dia, pois você fica tensa, chega em casa com dor de cabeça, essas coisas todas que vai do decorrer. Eu sinto, em relação ao corpo físico, que eu acho que isso, essa tensão essa coisa assim, sei lá, eu não sei te dizer, assim é o dia a dia, é a rotina. Dor que eu sinto no corpo, isso prejudica. Em mim reflete mais no corpo, no dia a dia. Eu sinto isso assim, sei lá, no ombro, na mão. Às vezes você vai para casa, e você só quer dormir, só pensa em dormir.

Eu me sinto bem, mas meu corpo está cansado pra caramba. Cansa, porque sei lá, só porque você trabalha o dia inteiro em pé já é uma canseira. Eu acho que é no decorrer do turno, mais ou menos lá pelo meio dia começo a sentir a fadiga. Até a hora do almoço você está ótimo, mas depois do almoço é que dá aquela moleza. Geralmente o pessoal reclama, e eu pessoalmente também, mas é depois do almoço que o pessoal reclama. Dá aquela moleza no corpo, aquele cansaço. Dá fadiga nas pemas. Acho que é o mais comum que dá essa canseira mais nas pernas, pelo fato de trabalhar de pé. Fadiga nas pemas realmente é uma dor tipo nas pantumilhas, tomozelos. Dor enjoadinha que depois que você escora a perna passa um pouco, mas quando você pisa o pé começa aquela dor geralmente na panturilha. Dor que o pessoal fala fadiga, aquela dor enjoadinha. Basicamente é isso para mim, mais nas minhas pernas, que eu sinto o cansaço.

De vez em quando me sinto indisposta, o trabalho em casa cansa bastante. Você dorme tarde. É um pouco cansativo. Cansaço. Avisa que é uma coisa repetitiva. Todo dia aquela coisa, aquela rotina, então cansa um pouco. Cansado de cansado 
com a mente. Chega uma hora você também não agüenta mais a cabeça, e a cabeça, acho, que manda no corpo. Eu fico initada. É coisinha que você faz, eu me imito. Ficar imitada é ficar agoniada por dentro. Tem dias que às vezes dá uma vontade de jogar tudo para o alto. Tem dia que fica cansado também. Às vezes eu sinto meio cansado de fazer a mesma rotina. Para dizer, às vezes fica meio comido pra mim. Às vezes chego aqui cansado, meio desmotivado, já sei como é o serviço. Eu gosto de trabalhar sim, mesmo sabendo que estou cansado, mas cansaço dura uma ou duas horas com um dia corrido, você nem vê as horas passar. Gosto de vir trabalhar, mas tem dia que o cansaço me vence, o cansaço me vence mesmo. Por mais que o pessoal fale assim que nunca fica cansado é mentira. Tem um dia que todo mundo na vida que cansa, é impossível falar que não, não estou cansado, nunca vou ficar cansado de trabalhar. Fico pensando, eu acho que estou muito estressado ultimamente porque o cansaço chega no limite, mas mesmo assim eu venho do trabalho, vão dizendo: "brigou, que está acontecendo", "não eu estou muito cansado!". Sentir cansado não é bom não. Se sentir cansado eu fico muito chato, fico estressado, o estresse em mim. O estresse chega ao máximo. Saber que no outro dia você tem que vir ao trabalho, você começa a ter aquele desânimo: caramba tenho que ir para a escola, aquela escola enche o saco, aquele serviço enche o saco. Como você se sente quando está cansado? Mal! Mas é ruim mesmo, pior que ficar doente. Você fica com a cabeça perturbada, seu corpo cansado, daí um une o outro e dai te derruba "facinho", dai que você fica desanimado.

Idéia central: Sinto-me cansado mental e fisicamente, chateado, sem ânimo, indisposto, irritado, só se quer dormir, deitar e não ver nada. Sinto o corpo pesado, me sinto agoniado por dentro. Sinto estresse, não quero sequer levantar um dedo. Me sinto meio acéfalo, fico tenso em relação ao corpo fisico, e sinto isso no ombro, na mão, fadiga nas pernas (dor "tipo enjoadinha" na panturrilha e tomozelos). Chega uma hora que não se agüenta mais a cabeça, quero jogar tudo para o alto e o cansaço chega no limite. Ficar cansado é pior que ficar doente. 


\section{(5) Discurso do Sujeito Coletivo sobre o Tema: Definição de fadiga}

Querendo ou não acaba-se transferindo para o dia a dia, por isso, pelo cansaço, pelo esgotamento, que acaba se tomando além de mental, físico. Porque esgotamento mental no nosso caso é normal mais o físico já não. Eu acho que hoje dentro de qualquer profissão as pessoas que trabalham com o cérebro, que tem que usar sempre toda hora o cérebro para conseguir conquistar seu espaço no mercado e desenvolver a sua função bem, vai ter todo dia um esgotamento mental que eu acho que é normal porque está desenvolvendo uma função que está mexendo com o cérebro, então acaba chegando num cansaço mental. Que pra mim é normal ou não é uma pressão como de um presidente de uma empresa que está falindo, não é diferente esse cansaço mental de um e de outro, mas em relação a transformar ele em cansaço físico que eu acho que é complicado. Essa questão de complicado em relação ao cansaço físico é você não estar desenvolvendo uma atividade fisica para te deixar cansado, então obrigatoriamente você não tinha que se sentir cansado fisicamente. Pelo cansaço, não pelo cansaço mental, pelo estresse do dia a dia isso acaba se tomando físico porque a pressão que acaba influenciando, além da conta eu acho que nas pessoas, realmente está tendo esse cansaço físico. Varias outras pessoas do departamento: "pôxa, estou tão cansado hoje". Aí você pergunta: você fez exercício? Fez ginástica? Você fez alguma coisa para estar cansado? Não! Dormiu no horário? Dormi. Mas a situação faz a gente ficar dessa forma. Parece que, não sei, tem alguma influência durante o sono que pode ser também. Este é um caso pra quem estuda realmente, os distúrbios do sono. Eu acho que é toda uma coisa de tensão realmente porque se eu fosse...durante o sono quando se sente tenso você se sente pesado, os músculos travados. Eu acho que é uma coisa muscular que te cansa fisicamente que não é bom, até pra desenvoltura de todo trabalho isso acaba não sendo bom.

Idéia central: É um cansaço mental que se transfere para o físico. Estou desenvolvendo uma função que mexe com o cérebro, chegando a um cansaço mental e tem uma coisa muscular que te cansa fisicamente. Há o cansaço físico também, apesar de não estar desenvolvendo uma atividade física. Parece que tem influência sobre o sono, com distúrbios do sono. 


\section{(6) Discurso do Sujeito Coletivo sobre o Tema: Estratégias de Enfrentamento da Fadiga}

Você tem que estar recuperando, assim, as energias sempre, sempre mesmo. Mas são momentos, são fases, que aí eu procuro fazer alguma coisa pra distrair, alguma coisa fora, pra melhorar isso. Eu saio daqui eu esqueço do senviço, esqueço o que ficou, esqueço.

Normalmente a gente levanta, vai dar uma volta, vai beber uma água, lavar o rosto, para sabe... Eu procuro chegar em casa e sair, espairecer mesmo, sabe, esquecer. Se tiver a oportunidade de pegar sexta, sair, viajar, assim só para sair um pouco daquela rotina. Ou então se estou em casa, pegar, alugar um filme, ou ir ao cinema, coisas assim que eu saia da rotina e espaireça um pouco a cabeça. Chamar os amigos para ir em casa, jogar, jogar baralho, essas coisas assim que isso faz a gente esquecer totalmente do serviço.

Descansar. Isso eu acho que é fugir um pouco. É o fim de semana. A gente tem que fazer, levar da maneira que dá. Eu procuro mudar um pouco das coisas, não ficar só naquele lugar, mudar um pouco de lugar. Senão eu mesmo me canso, a cabeça. Trabalhando você se distrai. Você não está nem vendo o que você está sentindo, vendo aquela correria que você está. Aí, quando você pára, ai começa a aparecer um monte de dor. Aí, você pára com a mente, ai começa. Às vezes a gente chega de mau humor. Nem todo dia a gente está de bom humor, mas saber levar isto tudo numa boa é saber conduzir a situação.

Eu acho que você tem que saber administrar. Se respeitar. A gente tem que saber se respeitar. Não é só viver no limite.

Tem que estar com a alma preparada. Estar com a alma preparada é tipo assim...Como posso dizer? É que você já sabe que você vai fazer aquele serviço. Mas mentalmente eu sei que tenho que ir lá trabalhar senão minha produção, meu ritmo de trabalho não pode cair. Então minha mente tem que estar preparada para suportar aquele instante, aquelas oito horas que se vai trabalhar aqui, depois você chega em casa, depois sei lá, dá um jeito, toma um banho, vai descansar um pouco, dormir umas duas horas, depois vai para o curso, depois do curso vai pra escola e assim continua.

É que meu trabalho, só dou risada. A cada dia é uma coisa nova que acontece. Um vai contando das histórias do outro. A gente começa a lembrar da escola, do ginásio, dai a gente dá risada. Um que escorrega a gente dá risada. Outro que vai lá faz umas besteiras a gente dá nisada. 
Idéia central: $O$ enfretamento da situação de cansaço passa por estar sempre recuperando as energias, descansar, fugir um pouco, apreciar o fim de semana, viajar. No trabalho, deve-se levantar, dar uma volta, lavar o rosto, beber água. Deve-se chegar em casa e sair para espairecer ou chamar amigos para esquecer totalmente do serviço. Saber levar tudo numa boa é saber conduzir a situação e estar com a alma (mente) preparada para poder suportar aquele instante. Manter a mente ocupada. Saber administrar, se respeitar. Dar risadas no trabalho, se divertir trabalhando. 


\subsubsection{Discurso dos Trabalhadores sem Fadiga ${ }^{11}$}

Dentre os trabalhadores entrevistados, 15 não apresentaram fadiga pela Escala de Chalder. Apesar destes trabalhadores não terem apresentado a fadiga eles expressaram alguns conceitos relacionados à fadiga. Isto porque a fadiga tem origem multifatorial e alguns aspectos, sintomas, podem estar presentes como, por exemplo, o cansaço, a ansiedade.

Lembramos que o cansaço é comum entre a população e a diferenciação para fadiga é se este cansaço não pode ser recuperado com o descanso. Os trabalhadores vivem rotineiramente esta situação de cansaço, somada às questões já referidas das estratégias de enfrentamento. Mesmo na Escala de Chalder os trabalhadores que não apresentaram fadiga se expressaram sobre sintomas e o porque se sentem cansados na rotina diária no trabalho e fora dele. Portanto é importante compreender o discurso destes trabalhadores sobre a expressão da fadiga, além de nos permitir uma comparação dos discursos com os trabalhadores que apresentaram a fadiga.

\section{(1) Discurso do Sujeito Coletivo do STA sobre o tema: Fatores Associados à Determinação da Fadiga}

Fora do trabalho nós temos que estar lendo todas as publicações que nós recebemos. Nós não temos tempo no nosso trabalho. Você fica bastante é desgastado porque você está vendo que tem que alcançar aquela meta porque a empresa tem aquelas premiações das revistas, ela sempre traz algumas premiações para os funcionários. Temos as nossas metas individuais, mas nós trabalhamos com meta de escritório. No nosso departamento não tem pressão. No nosso departamento até hoje eu não tive pressão. Tive incentivo de trabalho. Você tem que estar concentrado, bem atento ao que você está falando para aquele assinante, passando todas as informações. Nós não estamos vendo a pessoa

\footnotetext{
"Lembramos que os trabalhadores foram classificados sem a fadiga com base na Escala de Fadiga de Chalder.
} 
pessoalmente, mas estamos falando com pessoas que hoje está bem humorada amanhã está mal humorada. É um pouco complicado porque nós temos inúmeras objeções para estar destruindo no dia a dia. Você sentou aí na PA...você pode parar, pode conversar, tem liberdade, que eles não cobram nada. Você tem o seu salário e sua comissão, então você tem que batalhar para melhorar o seu salário que o salário é baixo então você melhora o seu salário com a comissão, então quanto mais você vender melhor é para você. Todo mundo pensa assim, então ninguém levanta, ninguém conversa, fica todo mundo trabalhando, trabalhando, trabalhando, e acaba ficando meio estressante, porque você fica o tempo inteiro sentado ali, vendo número e liga, e fala, aí marca. $E$, a comissão, então a gente não pode ficar perdendo muito tempo. Até pode perder um tempo, mas se já tiver com a meta diária, que a meta diária são 6 assinaturas. Tendo esta meta diária ai você pode dar uma relaxada, mas não é normal acontecer isso. O trabalho às vezes é estressante quando o cliente te xinga, as vezes tem uns que não deixam você nem abrir a boca e já gritam: "eu não quero assinar a revista, não quero saber". Você liga com a maior boa vontade e a pessoa não deixa você explicar. Você fica com raiva, porque você quer explicar que já foi solucionado. Então você se sente ruim por não ter dado uma informação. Ai, Horrivel!!! Uma sensação assim que você não conseguiu explicar aquelas informações.

Nesse tipo de serviço tem que ser mais calmo porque se você for estourada um cliente fala " $A$ " para você e você não gostou do " $A$ " você vai retrucar e você não pode destratar o cliente. Querendo ou não existe aquele ditado: "o cliente tem sempre razão". Então você não pode falar absolutamente nada para ele. Em vendas sempre tem cobranças. Cobrança muito grande. A gente também faz essa própria cobrança, porque nosso salánio depende das nossas metas, das nossas vendas. Tem mês que está pior, tem mês que está melhor, mas mesmo assim é um desafio. Não tem jeito, você vem trabalhar, você tem lá sua meta diária aí você não consegue, ai começa a bater aquele desespero. Então, cai as vendas, desanima um pouco. É difícil, é meio complicado, mas a gente tenta. Então, a gente tenta, tenta reverter, tenta trazer porque a gente vive disso. É competição individual, você por você mesmo. Como eu trabalho com vendas, estou vendendo lucro para mim. É uma pressão de mim para mim mesma. Se eu não vendo, no final do mês que eu vou sentir aquilo no bolso. Se eu não vendo como é que eu vou pagar as minhas contas? Então essa é que a pressão. Tem que dar um retomo também 
para a empresa, porque senão eu não fico aqui muito tempo. Nós trabalhamos em cima de resultados e nós temos que estar mostrando resultados para eles.

$A$ área de vendas em si independe do telemarketing ou não. Ela é uma área que é diferente de uma pessoa com salário fixo, porque você nunca sabe quanto vai ganhar. Você tem objetivos e você precisa cumprir independente se você venda ou não. Só a pessoa falar que compra no telefone não garante a venda. Depende do extemo nas vendas, no caso a venda ser efetivada, ser concretizada. No cartão de crédito garante a venda. Cada um tem o seu percentual, o ideal seria que vendesse $100 \%$ de cartão porque aí a pessoa fica devendo para o cartão e nós recebemos tudo direitinho. Mas não é assim. Então esse é um fator que gera insegurança. Então você já trabalha numa uma certa ansiedade.

Então é uma frustração enome assim, você saber que você tem competência, você saber que você tem toda a base que você precisa e você não tem a chance que você precisa, mas no Brasil que a gente está, é assim mesmo. Só isso. O extemo é só isso. , lidar com o público você tem que estar preparada para tudo, desde um máximo de gentileza até uma ofensa.

A sensação que o trabalho me dá não é o prazer. Porque o prazer ai eu acho que não justifica. Vamos colocar assim: satisfaz. O prazer eu não consigo vivenciar em termos de trabalho. O prazer já me dá uma sensação de relaxamento mesmo.

Idéia central: $O$ trabalho exige que determinada tarefa seja realizada fora da jornada, como, por exemplo, ler as revistas. Há um desgaste provocado pelas tarefas que devem ser realizadas com atenção. Deve-se estar concentrado, com autocobrança, autopressão, mas é um desafio. A pressão é um incentivo. $\dot{E}$ também um trabalho que depende do externo, gera insegurança, tendo que trabalhar sob certa ansiedade. Não traz prazer.

\section{(1) Discurso do Sujeito Coletivo do SA sobre o Tema: Fatores Associados à Determinação da Fadiga}

Aqui a gente está trabalhando, mas a gente precisa do emprego e a empresa também precisa que a gente olha esta parte da qualidade porque se não, não adianta. Porque lá a gente trabalha assim, gaveta e saída. O operador não tem nem para onde ir. Vou para gaveta, trabalhando o dia inteirinho, puxando. Tem dia que 
parece que você se esforça demais. Ás vezes a carga de serviço é alta e as vezes também está pouca quando tem queda de serviço. Aqui é cheio de altos e baixos, uma hora a carga de serviço está lá em cima, outra hora está lá em baixo. Você trabalha bastante e também não trabalha. Acho que aqui tem muito tipo patrão. Que tem uns que são legal, mas tem uns que pega duro assim com você. É complicado. Por isso que eu falo que exige muito a nossa atenção. Prestar atenção é você trabalhar tranqüilo, sem ninguém estar ali deixando você deprimido, então você consegue prestar atenção no que você está fazendo.

Puts, é hoje, hoje é o dia, ai não tem nem pra onde você correr. Ter estresse acho que é o dia a dia, você vê um monte de coisa ruim.

A maioria das máquinas não tem a equipe completa. Eles pegam o pessoal e divide. Vai completando as equipes em outras máquinas e assim a gente tem sempre que estar trabalhando. Às vezes os paletes também ficam pesados, porque eu não sei se a madeira é que está verde ou se são eles que tomam chuva e ficam molhados. Isso ai acaba se tomando pesado, é pesado mesmo. Então você trabalhando em movimento, porque é movimento, é rápido não é brinquedo não, não é coisa de ficar de fazer devagarzinho não. Você tem que...senão você não consegue acompanhar a produção da máquina, e não pode acumular. Porque tudo que vai fazer, vai ter que fazer movimento repetitivo. Então você tem que desdobrar um pouquinho. A firma passa por vários cortes, a firma passa por vários problemas. Só dia de revista pesada que é muito pesado, cruel pra gente, principalmente aquele dia que você não está legal. Dia que não está legal é dia que se está menstruada. Pesado, por exemplo, você está ali no movimento, vendo um pacote daqui, palete, correria. É muito comido. A gente é mulher, a gente sente, que você chega em casa, você tem que lavar, passar, cuidar de casa, cuidar de marido, se preocupar com as responsabilidades da gente e ainda trabalhar fora. Então isso cansa um pouquinho a gente. Então quando eu chego em casa também está pensando que eu chego e vou sentar? Que nada, muitas vezes eu nem consigo trocar de roupa, do jeito que eu chego eu já vou amumar a cama, já vou lavar a louça, por que minha filha inventou de ter um cachorro também.

Eu tenho um problema de cálculo nos rins e quando ataca...Eu tenho que estar sempre fazendo acompanhamento médico e fazendo tratamento para não ter muitas dores, porque todas as vezes que acontecia de menstruar pra mim, parecia que o mundo ia desmoronar em minha cabeça, era uma cólica tão grande, tão grande me dava ânsia de vômito que tudo me imitava. Me dava dor de cabeça, era 
dor de coluna, parecia que travava a musculação. E tudo bem, ai eu comecei a fazer um monte de exame e o médico viu que tinha um mioma na parede do útero. Eu fui atropelada uma vez, atropelada não, foi por um acaso aconteceu sem o empilhador querer. $E$ eu tava assim distante. Ficava aquele monte de palete embalado assim, empilhado um em cima do outro. E quando ele vinha, que eles correm muito no dia de sábado para poder dar conta do serviço, ai a bateria da empilhadeira pegou numa daquelas tábuas lá, elas são só grampeadas, e então não teve dúvida, quando veio acertou assim, e a tábua voou com tudo, com aquele impacto todo e acertou nas minhas costas. Aquilo ali parecia que uma pessoa tinha pegado com as duas mãos assim e descido com tudo nas minhas costas. Ficou pretinho na hora no lugar e eu senti dor muito tempo na coluna. Eu já sinto devido ao esforço que eu faço. A gente sente porque tem serviço que é pesado. Sinto dor de coluna.

Idéia central: Há dias em que parece que o esforço é maior. O trabalho exige muita atenção. $\dot{E}$ um trabalho com repetitividade de movimentos. $A$ maioria das máquinas não possuem equipe completa e é, portanto, um trabalho cruel, serviço pesado. O trabalho tem que acompanhar a produção da máquina. Há acúmulo de trabalho no setor de acabamento e mais o trabalho doméstico. Aparecem problemas de cálculo renal, mioma e acidente de trabalho.

\section{(2) Discurso do Sujeito Coletivo sobre o Tema: Características Individuais}

O meu trabalho é bastante divertido, porque nós acabamos nos dando com vários tipos de pessoas. A vivência do STA na empresa, para mim, tem trazido crescimento de como conversar, como lidar com as pessoas. Eu tenho bastante amizade, e procuro sempre onde eu vou fazer amizade, sempre novos amigos, viajo bastante.

Gosto de bagunçar bastante, para descontrair um pouco, porque é um trabalho que você tem que estar legal para conversar com o cliente. Saiu daqui de dentro eu já cancelo tudo. Saiu daqui do portão para fora eu sou outra pessoa, saio cantando, pego o meu ônibus, vou para a minha casa, vou jogar bola a noite, vou para a faculdade... 
Quero entrar na área de marketing e publicidade, então o telemarketing é uma passagem do marketing. Não é com o telemarketing que eu pretendo ganhar a minha vida. Eu pretendo ser reconhecida. Pretendo ser uma ótima advogada, uma ótima juiza. Não vou dizer que é uma função na minha vida profissional porque eu tenho um sonho de fazer uma faculdade de enfermagem. A área especifica para o resto da vida é a área de jomalismo que eu pretendo estar exercendo para o resto da vida mesmo. Porque na nossa vida profissional a gente tem que visar o crescimento. Se não tiver o crescimento você vai viver o resto daquela vida ali.

Meu ritmo é acelerado, eu gosto de falar muito, converso demais. Eu sou uma pessoa tranqüila, eu sou uma pessoa bem calma. Às vezes até a minha calma me imita de tão calma que eu sou. Desespero não porque eu não fico desesperada, senão eu não trabalho, a gente fica preocupada. Sou assim um pouco caxias, mas isso desde quando eu comecei a trabalhar. Eu sempre, independente da empresa, do serviço, eu sempre vestia a camisa. Para mim regras são regras. Eu não tenho dificuldades em aceitá-las, nada disso. Eu mesmo tenho aprendido a respeitar os meus limites, porque eu também nunca fui de respeitar muito os meus limites. Eu ia um pouco além. Eu gosto de prestar atenção porque se eu mandar um pacote de revista e ele está completo ali e ele está com revista ruim é porque eu não prestei atenção. Eu acho que se eu errar eu tenho que assumir o meu erro. Faço tudo certinho minhas coisas. Também eu sempre aprendi: quando eu chego aqui o problema meu fica tudo lá fora, não carrego aqui para dentro. Não confundo nada. Não trago, o que fica lá fora, fica. Passei daqui já era. Só serviço. Hoje em dia, assim, me sinto bem melhor.

Eu sempre gostei de trabalhar com serviço assim agitado, sabe, rápido. Serviço lento para mim só me traz sono, então eu prefiro trabalhar assim num ambiente mais agitado, mais rápido, que é o acompanhamento de máquina. Então eu gosto de trabalhar em movimento eu me sinto até mal se eu tivesse que ficar parada olhando só os outros em movimento. Eu não sei acumular serviço, eu fico desesperada. Se eu não der conta do serviço, eu já fico nervosa, tem que dar de qualquer maneira.

Tirando, pra mim, tirando a dor está ótimo já, eu já agüentando...Olha a única coisa insuportável é você trabalhar com dor. Com dor é ruim porque tudo que você vai fazer nunca está bom, mas se eu não estou com dor eu gosto de trabalhar E eu não preciso ninguém estar mandando. 
Ah, não tem essa de sensação, nem ansiedade, assim, não tem isso que eu faça, que me deixe assim diferente do que é o normal. Eu gosto do que eu faço, eu gosto. Eu acho assim, não tem nada que me deixe estressada, não tem nada que me deixe ansiosa, que acabe com o meu dia. Eu me sinto tranqüilo e seguro, estou fazendo o melhor possível e mesmo não sendo uma área especifica que eu pretenda ficar para o resto da vida. Eu sou uma pessoa que fora do trabalho procuro ser uma pessoa digna, que respeito tanto a minha familia quanto a minha namorada. Não me sinto mal, não consigo me sentir mal. Muito difícil eu estar mal com alguma coisa. Graças a deus eu sou super ativa, assim, então não consigo ficar sentada. Mesmo em casa não consigo ficar sentada sou formada, pósgraduada eu tenho formação boa para caramba e sou operadora de telemarketing. $\dot{E}$ inevitável. $\dot{E}$ uma frustração. Mas eu tenho uma cabeça boa porque eu penso assim: "é um degrau na minha escada". Eu tenho uma opinião que quem cresce muito rápido cai muito rápido. Sou formada em comunicação. Por isso que a coordenadora falou: "comunicação para você é exacerbada, porque você é super, hiper comunicativa e no telemarketing você tem que ser mais centrada". É uma coisa que eu estou trabalhando.

Idéia central: Não é um trabalho para o resto da vida. Almejo outras profissōes, como ser enfermeiro, advogada (ótima juiza), trabalhar no marketing, fazer jornalismo. O ritmo é acelerado, mas se a pessoa é tranqüila, calma, não fica desesperada. Sou um pouco caxias, faço tudo certinho, gosto de serviço rápido, gosto do que faço, não preciso de ninguém mandando. Não tem nada que me deixe ansioso, que acabe com o meu dia. Tenho aprendido a respeitar os limites. Gosto de bagunçar para descontrair e se não fosse a dor já estaria ótimo.

\section{(3) Discurso do Sujeito Coletivo sobre o Tema: Identificação da Situação Problema}

Assim, você fica desgastado fisicamente e também na sua consciência porque são várias informações. Às vezes você fica até sem voz. Procuramos sempre estar controlando a nossa voz para não falar muito, para não prejudicar, porque, olha, a nossa ferramenta de trabalho é a nossa comunicação. 
O trabalho é cansativo, mas é gostoso. Ele é cansativo até pelo red fone que fica o tempo inteiro no ouvido e fica fazendo aquele tom. E também por alguns clientes que chegam a ser meio grosseiros. Cansativo pelo horário de trabalho. Você tem que trabalhar muito rápido. Então tem um almoço bem rápido de 30 minutos. Então não dá nem para a gente comer direito. O horário de entrada é 8:00 horas. Eu vejo como cansativo porque eu saio de casa às 5:30 da manhã porque eu moro longe, então eu tenho que sair bem cedo. Chego aqui 15 para as 8:00. Aí você já começa a trabalhar porque não é igual um emprego que você chega às 8:00 ai você vai para um lado, vai para outro e começa a trabalhar praticamente às 9 horas, e aqui não, você tem um horário para cumprir, então tem que trabalhar das 8 ás 2 . Não tem parada. Não é um serviço que vocé pode parar, relaxar, conversar, mudar o assunto, levantar da mesa e dar uma volta. Não, é fixo. Eu digo assim que é um trabalho cansativo porque você fica muito tempo fechado na frente do computador. Deu 2 horas, ai o pessoal já está desligando o computador levantando da mesa e indo embora. É normal, quase todo mundo do departamento é assim, porque não agüenta ficar trancado ali. Também eu leio mais de 150 revistas por mês. Às vezes cansa. Geralmente final de mês, é uma coisa que pega mais, aumenta mais, porque você tem um prazo, última semana para fechar. Então ai vai começar e ficar a última semana: 4 dias, 3 dias, 2 dias. Então você fica numa pressão violenta. Ai assim é um trabalho bem individual mesmo, de cada um. Tem esta parte triste que é você ficar ansiosa, controlar e ter a satisfação de ter conseguido chegar lá. Quem trabalha com vendas é um pouco mais inseguro. Quem tem ansiedade tem, eu acho que é do ser humano né? Mas isso de qualquer forma tem que ser trabalhado. Então assim, se eu faço uma venda para você e no tal dia você não tem o dinheiro para pagar, eu não recebo. Tudo que a empresa me pede eu tenho feito direitinho, mas a pessoa não pode pagar, então foge do meu controle. Aí você fica um pouco insegura. É uma coisa que independe da sua maneira de estar trabalhando a pessoa estar pagando ou não.

O que eu faço, muita gente, eu acho que pelos tempos que estão aqui, não gostam mais de fazer, por exemplo, de limpar máquina, essas coisas assim. De eu ter que limpar estou aceitando isso até agora super bem, normal, assim, como um serviço. O chato para mim do meu serviço é ser muito repetitivo toma-se cansativo se você ficar fazendo a mesma coisa. O grande problema que eu acho que ele tem assim, por exemplo, do pessoal que tem bastante tendinite é a parte de ser muito repetitivo, você faz, por exemplo, o seu tumo inteiro o mesmo movimento, o dia 
todo, trabalhando só os braços. Imagina, por exemplo, você uma semana inteira fazendo a mesma coisa. É sempre. no mesmo lugar, trabalhando no mesmo lugarzinho ali, fazendo a mesma coisa, só movimentando seus braços. Quer dizer, não é assim cansativo é repetitivo, chato. Não é fácil, você também, trabalhar muito tempo, sabe, que tem uma hora que você cansa, tem dia que eu não venho, acho que eu não estou no lugar certo, acho que está na hora de procurar outra coisa. É um cansaço de gosto de trabalhar. Eu já fiquei um período desempregada e era um cansaço de estar parado em casa. Muito complicado. Então quando está trabalhando é um cansaço normal. E fisicamente não tenho assim cansaço: "ah! Eu estou acabada", não! Num geral, principalmente hoje em dia em relação ao pais, nenhuma relação a empresa ou a mim, as coisas ficam mais dificeis mesmo, ai dá a sensação um pouco de castração, de raiva, assim raiva no sentido de não ter sido o dia inteiro super positivo. Quando a gente fala positivo, para nós que trabalhamos como se fosse venda...é venda! Você sabe que vendedor o dia que não vende ou que é menos, é complicado.

Idéia central: As várias informações necessárias para desenvolvimento do trabalho me deixam desgastado fisicamente e na consciência. O trabalho é cansativo pelo "head-fone", pelo horário de trabalho, jornada tensa e não poder relaxar, por ter que ler muitas revistas no mês (aproximadamente 150) e é um trabalho que foge ao controle e não pode parecer que é venda. É um trabalho que gera ansiedade e insegurança. As pessoas têm tendinite pelos movimentos repetitivos e trabalhar muito tempo tem uma hora que cansa. $\dot{E}$ um cansaço.

\section{(4) Discurso do Sujeito Coletivo sobre o Tema: Expressão da Fadiga}

Cansado não. A vista acaba ficando meio cansada, porque o computador, a gente sabe, mais descansada que a pessoa esteja ela acaba tendo a vista mesmo. Não é nem cansaço e sim a vista acaba ficando um pouco cansada. Isto que eu acho cansativo. É esse o meu entender no cansativo. Acho que tipo assim, as coisas que você vê acontecendo assim, cada dia e assim também acho que causa muito estresse. Sentir estressado é você às vezes estar de mau humor. As vezes você não fez nada, você acorda assim e você não tem disposição nem para dar bom dia para sua mulher. Acho que isso aí é que é o estresse. No meu caso é difícil de 
acontecer isso, mas três semanas atrás aconteceu de manhã eu acondar assim, ai minha mulher falar comigo tipo: "você. é mal educado". "Eu sou mal educado? Eu? Dá uns cinco minutos, eu paro e penso: "puta, fiz isso ai, mas sem nenhum motivo". Aí eu falo assim: "acho que é estressado mesmo". Mas se arrepende, você pára e pensa: "porque eu fiz isso?". Não deu motivo, acordei agora, na noite passada foi boa, dormi bem, assisti televisão, não sei que lá, peguei fui dormir e não aconteceu nada, acordo de manhã de mau humor? Acho que o estresse é assim". Acorda já chateado, e você não fez nada.

A hora tipo não passa, você fica muito tempo na mesma coisa, para mim a hora não passa. Ai por isso se toma cansativo, aí você chega em casa, por exemplo, você não fez tanto esforço físico, mas chega em casa fica com a impressão que você está cansado, que trabalhou bastante aquele dia.

Cansativo é quando você não vende. Se você está ali falando com pessoas e vendendo, tudo bem, te cansa, mas te rende, mas se é um dia que você está falando e não vende, aquilo esgota. É que cansa você, porque o trabalho vendendo e recebe muito não, isso cansa! Cansa você ficar com a atenção. Esse dia cansativo e eu vim trabalhar, e não rende, não vende e você sai se cobrando porque aqui não vendeu e chateada ao mesmo tempo. Eu pelo menos tenho muita tensão aqui nas costas. Já cheguei a usar um bom tempo aparelho, que eu já tinha a mordida torta e a minha tensão ficava trincando os dentes. Eu sentia muita dor de ouvido, se era num dia cansativo. Tem épocas, vem dos altos e baixos, quando você está com raiva. Tem dias assim que eu fico cansado, terça feira agora foi bem puxado mesmo o serviço. Acho que é devido ao esforço físico e mental. Às vezes você está fazendo muito esforço assim, começa a ficar pensando. Tem vez que até sua gaveta lá está acabando o material. Você está tipo viajando. Quando você menos vê seu olho está secando. Acho que às vezes o cansaço também causa estresse. Não sei se é do seu jeito físico, como você está ou que você trabalhou. Eu cheguei, deu umas duas horas não estava agüentando mais, de tanta dor nas costas, mas todo mundo reclamando. Sinto dor de coluna. Quando eu trabalho com as revistas pesadas, quando eu trabalho com revista que às vezes vem com material as vezes encaixado de fora, por exemplo, aquelas caixas que vem com cdrom, elas são pesadas. A gente tem que pegar de cima para abrir, não para trabalhar. Para pegar e pôr na gaveta. Para retirar do estrado. E tem que por próximo de você. Ai, uma ou duas, ninguém vai sentir muito, mas durante 7 horas você vai sentir. Agüentando assim, a gente vai fazendo um esforço que pode, na 
medida que agüenta fazer. Aí, na hora que não der pra fazer mais, ai a gente fala: "agora quem está cansado sou eu, eu também preciso me cuidar". Só que tem hora, tem dia que a gente se sente cansada, principalmente quando você não está bem de saúde, mas fazer o que? Isso é a vida mesmo. A vida da gente é cheia de altos e baixos. Uma hora está lá em cima, outra hora está com o astral lá em baixo. Se sentir cansada é você achar que está fazendo porque tem que fazer, porque não tem ninguém para fazer por você e vocé tem que fazer porque você sabe que se você não fizer aquilo vai ficar parado esperando, por quem? Às vezes eu me sinto um pouco cansada, mas cansada assim, o dia de revista pesada que é muito pesado. A revista chega a pesar 8 quilos e 600g, 680g. Então eu sinto que para a gente mulher, mulher é um pouco frágil, mas eu não me troco por vários homens aqui dentro. Sentir cansada é sentir frágil. Sinto cansada no meio do dia. Sentir no corpo esse cansaço é sentir vontade de sentar, vontade de você encostar no seu cantinho, da sua casa, por exemplo. Você não vê a hora de ir pra casa. Chegar em casa, você tomar um banho, dar uma relaxada, respirar, descansar para o dia seguinte. Ora, você acha que no dia seguinte a gente que é dona de casa descansa? Difícil. Mas eu tenho que descansar. Então você tem que trabalhar com o que? Com sua mente, né? Mente positiva.

Você vai lá, descansa em casa e nossa!! Cumpri meu objetivo de hoje, cumpri o que eu tinha que fazer hoje. Ai, é diferente, é bem legal, assim. Esse cansaço bom, é assim: está cansada por você trabalhar. O cansaço fisico. Mas eu assim, olha, pronto consegui, chego, eu descanso, acordo e já estou bem, vamos para um próximo dia. Não é assim um cansaço de: "puts, que saco, ai, eu continuo desempregada".

Idéia central: Sinto a vista cansada, mas não é cansaço. Sinto estresse, mau humor, acordo chateado e não faço nada. Canso porque não recebo muito. Chego em casa cansado. Sinto tensão nas costas. Tenho mordida torta e tensão. Costumava trincar os dentes. Sinto dor de ouvido em um dia cansativo, dor nas costas, dor na coluna, devido ao esforço físico e mental. Sinto tudo isso porque a jornada é longa em relação ao tempo. O cansaço causa estresse. Não tem ninguém para fazer por você e a mulher é um pouco frágil. Cansativo é quando você não vende. 


\section{(6) Discurso do Sujeito Coletivo sobre o Tema: Estratégias de Enfrentamento da Fadiga}

Quando eu chego na empresa, se eu estou cansado, já me ajuda. Dá uma motivação: "ôpa, legal, mais um dia de trabalho, vamos lá, vamos batalhar".

Como eu sempre trabalhei em local fechado, banco, esses lugares, eu saio de vez em quando, dou uma pausa no sistema, vou até ao banheiro, vou tomar uma água, depois retomo. Então, eu dou uma parada para dar uma relaxada, pensar um pouquinho, até mesmo sem levantar da mesa eu páro e olho todas aquelas ligações que eu fiz Levanto, acho que não estou legal, lavo o rosto, então, agora eu vou voltar e vou vender. Sento lá com esse pensamento e vou para cima e consigo. Eu fumo, então quando me estresso demais eu coloco lá o pause e vou fumar, vou tomar uma água e não tomo café. Enquanto você fuma, você vai espairecendo um pouco, aí, você volta legal. Eu até me percebo as vezes que eu fico um pouco mais séria, falo diferente, então ai eu dou uma parada: "nossa como eu estou ansiosa". Respirar no teu local, ou dar uma esticada ou sair, dar uma volta, tomar água, ou vai até o banheiro, dar uma volta pra voltar, diminuir um pouco a adrenalina $e$ nomalizar. Lidar com a ansiedade é controlar, perceber que está alterada. Controlar um pouco, sair, dar uma volta, tomar uma água, ir até ao banheiro, dar uma relaxada, porque as vezes acaba alterando a forma do trabalho mesmo, até com relação a voz. Sentir essa insegurança é ter que aprender a trabalhar com ela, conviver com ela e vender mais. Eu tenho uma dificuldade, eu precisava trabalhar um pouco mais este lado assim de meditar, sabe. Eu precisava buscar mais isso, de meditar, de ansiedade, apesar de que ansiedade não, ansiedade eu já estou trabalhando bem, eu já fui estar indo buscar e acaba ajudando também a própria meditação. Eu faço acupuntura. Então você põe todas as armas que você tem para trabalhar, então você sempre tem aperfeiçoamento, isso não tenha dúvida. Então você está ali prestando a atenção, então você está vendo que você está progredindo, porque todo dia você aprende coisas novas.

Como a gente chega aí, um ajuda o outro, dá informação para o outro. Se você está precisando de uma ajuda vem um amigo e te ajuda, então o seu dia no cotidiano, isso facilita, tanto no viver com os amigos quanto no trabalho que a gente exerce você faz um trabalho com você: "eu sou capaz de fazer! Que é isso?". Não vai jogar a toalha em você, com você mesmo. Tem o lado chato, mas tem o lado bom então a gente busca o lado bom, que é estar procurando suprir este outro lado, vendendo mais e acaba acalmando. 
Eu estou subindo para estar crescendo aqui dentro da empresa mesmo. Então aí uma vez que você consegue um emprego numa empresa como esta, nossaaa! Olha que legal.

Aí, eles vão lá, fazem a ginástica, dá aquele ânimo. Então, aquela dor que eles estão no corpo, já dá aquele alívio.

Aí, foi que veio minhas férias. Acho que não mudou nada. O serviço é o mesmo, só que eu entro as 6:00 e saio às 14:00 horas. Eu pego e eu almoço dez horas. Agora estou até planejando, se Deus quiser, viajar com minha esposa, nas próximas férias, ai é para curar de vez. A gente fica mais na saída, uma hora em gaveta, uma hora em conserto, é assim. Aí, o tempo vai passando quando você vê esses 22 anos para mim passou tão rápido que parece que foi outro dia que eu entrei aqui e eu garanto para você que entre minha casa e aqui eu acho que eu me sinto melhor aqui, porque eu chego em casa e fico sozinha, eu tenho que fazer as coisas, mas sozinha.

Tem de trabalhar com a mente. É você só pensar em coisas positivas, coisas boas. Você não ver derrota, você não ver problema. Problema para você é problema? É? Você passa por cima, vai embora. Resolve os problemas da melhor maneira possível. Que é importante isto.Você não pode deixar um problema sem resolver. Você passar por cima deles é você resolvê-los e dar solução pra eles. E eu não preciso do meu trabalho só hoje, preciso dele por bastante tempo. Então, eu procuro fazer as coisas da melhor maneira possivel. Viver bem com meus colegas de trabalho que eu acho que isto é muito importante. Um bom ambiente. Não reclamar, não criticar. Que ninguém gosta de ser criticado. Ninguém gosta de reclamações. Doença para mim não existe. Para mim doença não existe. Existe na cabeça das pessoas que gostam de ficar doente. Eu não sou assim. Encaro a vida assim: eu vejo a vida bem de frente.

Idéia central: O cansaço pode ajudar, funciona como uma motivação. Saio de vez em quando, faço uma pausa no sistema, vou ao banheiro, lavo o rosto, vou tomar água, vou fumar para espairecer e faço ginástica no trabalho. Tem que aprender a conviver com a insegurança e vender mais. Medito, faço acupuntura. Os colegas de trabalho se ajudam mutuamente. Não se pode jogar a toalha em você mesmo. Deve-se pensar que se está progredindo, que problemas não existem. Se existem, deve-se resolvê-los. Acredito que doenças não existem, só existe na cabeça de quem está 
doente. Lidar com a ansiedade é controlar. Quando se sentir insegurança, deve-se aprender a trabalhar com ela. Deve-se usar as armas que se tem para trabalhar. Tirar férias. 


\subsubsection{Comparação dos Discursos dos Trabalhadores com Fadiga e sem Fadiga}

É importante compreender nos dois grupos qual foi a freqüência na abordagem dos temas sobre a determinação da fadiga e sobre a fadiga. Esta freqüência de abordagem dentre os trabalhadores entrevistados é apresentada no quadro 9.

Quadro 9 - Distribuição dos trabalhadores segundo a frequência de abordagem dos seis temas do discurso.

\begin{tabular}{|l|c|c|}
\hline Temas Selecionados & N de Trabalhadores que abordaram o \\
tema \\
\hline \begin{tabular}{l|l|} 
Com Fadiga \\
$(\mathbf{N = 8 )}$
\end{tabular} & $\begin{array}{c}\text { Sem Fadiga } \\
\text { (N=15) }\end{array}$ \\
\hline \begin{tabular}{l|c|c|}
\hline Fatores associados à determinação \\
da fadiga
\end{tabular} & 8 & 15 \\
\hline Características individuais & 8 & 15 \\
\hline Identificação da situação problema & 8 & 10 \\
\hline Expressão da fadiga & 7 & -- \\
\hline Definição de fadiga & 1 & 11 \\
\hline $\begin{array}{l}\text { Estratégias de enfrentamento da } \\
\text { fadiga }\end{array}$ & 4 & 8 \\
\hline
\end{tabular}

No que se refere aos fatores associados à determinação da fadiga, os dois grupos os abordaram com igual freqüência, ou seja, todos os componentes dos grupos falaram sobre $o$ assunto. $O$ trabalho e como ele se apresenta para o individuo é um tema de certa forma fácil de abordar, pois está relacionado à vivência cotidiana, perceptível, por ser o "seu" mundo de trabalho. Os trabalhadores passam 8 horas de seu dia no ambiente de trabalho, além de gastar mais horas com a locomoção até seu local de trabalho. Em resumo, o trabalho toma uma boa fração das nossas horas diárias. 
As falas sobre as características individuais também apresentaram igual freqüência nos dois grupos e vale a mesma referência que para os fatores associados à determinação da fadiga, pois não é uma questão difícil de abordar, quando relacionada às atitudes diante do trabalho. Os individuos entrevistados foram além da relação trabalho, colocando como pensam e enfrentam a vida.

Já para os outros temas houve variações na freqüência de abordagem. Para o tema da identificação do problema a freqüência foi $100 \%$ para os trabalhadores com fadiga. Para os trabalhadores sem fadiga, apenas $66,7 \%$ abordaram o tema. Sobre o tema "expressão da fadiga" é importante observar que os trabalhadores que não apresentaram fadiga abordaram este tema. Este fato pode ser explicado pela percepção da sensação de cansaço, situação comumente vivida e identificada como gerada pelo trabalho e afazeres domésticos, tendo reflexos não só no individual como no coletivo de trabalho. A definição de fadiga, segundo nosso entendimento, só foi abordada por um indivíduo, e este apresentou fadiga na escala. Quanto às estratégias de enfrentamento, não houve uma abordagem unânime, mas uma proporção de $50,0 \%$ para os trabalhadores com fadiga e $73,4 \%$ para os trabalhadores sem fadiga.

A comparação será apresentada nos próximos quadros iniciando pelos fatores determinantes no quadro 10. 


\section{(1) Tema: Fatores Associados à Determinação da Fadiga (STA)}

\section{Quadro 10 - Comparação dos discursos dos trabalhadores do STA, com e sem fadiga, sobre o tema de Fatores Associados à Determinação da Fadiga}

\begin{tabular}{|c|c|}
\hline Trabalhadores com fadiga & Trabalhadores sem fadiga \\
\hline $\begin{array}{l}\text { - Tem que ficar tensionado com o cliente. } \\
\text { - Tem que ter atenção e responsabilidade. } \\
\text { - Tem que se esforçar. } \\
\text { - Tem metas e números que leva a passar dos } \\
\text { limites pessoais. } \\
\text { - Fim de mês cansa um pouco mais. } \\
\text { - Difícil vender porque hoje em dia ninguém quer } \\
\text { comprar. } \\
\text { - É condicionado a autopressão necessária. } \\
\text { - Falar, falar e não conseguir. } \\
\text { - Trabalho pelo salário fixo mais a comissão. } \\
\text { - Passando por um processo de doença, com } \\
\text { apnéia do sono e algum distúrbio do sono. }\end{array}$ & $\begin{array}{l}\text { - O cliente sempre tem razão. } \\
\text { - Tem que estar concentrado bem atento, exige a } \\
\text { nossa atenção. } \\
\text { - Fica todo mundo trabalhando, trabalhando, } \\
\text { ninguém levanta ou conversa. } \\
\text { - Não consegue a meta diária bate aquele } \\
\text { desespero e se desgasta. } \\
\text { - Complicado porque tem inúmeras objeções a } \\
\text { estar destruindo. } \\
\text { - Não considera pressão, mas incentivo de } \\
\text { trabalho. } \\
\text { - Cobrança muito grande e autopressão. } \\
\text { - Tem que ler publicações fora do trabalho. } \\
\text { - O trabalho é estressante quando o cliente te } \\
\text { xinga, tem que estar preparada para tudo. } \\
\text { - O trabalho é um desafio. } \\
\text { - Competição de você por você. } \\
\text { - Se não vendo como vou pagar as minhas } \\
\text { contas. } \\
\text { - Se não der um retorno não fico aqui muito } \\
\text { tempo. } \\
\text { - Nunca sabe o quanto vai ganhar e gera } \\
\text { insegurança, trabalha com certa ansiedade. } \\
\text { - A sensação que o trabalho me dá não é o } \\
\text { prazer. }\end{array}$ \\
\hline
\end{tabular}

A descrição dos trabalhadores, conforme o quadro 10 , se apresenta como um complemento entre os dois grupos de modo que ocorrem citações comuns, umas complementando as outras. Não se observa diferenças ou contradições que chamem a atenção. Os trabalhadores, com ou sem fadiga, 
apontam vários fatores envolvidos no processamento diário do trabalho. Como o trabalho é realizado e suas exigências, é uma vivência comum para estes trabalhadores e esta situação é percebida igualmente por todos eles. Por exemplo, todos percebem que a forma de remuneração por um salário fixo mais a comissão é um fator que os faz trabalhar sem parar para poder alcançar um bom salário. A possibilidade de não alcançar as metas leva ao desespero, tendo como saldo o desgaste. As situações apontadas nestes discursos levam ao entendimento de que as exigências do trabalho são grandes na esfera mental/cognitiva fazendo que este seja um forte componente desta atividade. A exigência de esforço físico fica por conta do trabalho realizado com manutenção de postura estática sentada em frente a um computador por toda a jornada de trabalho. A leitura de revistas fora da jornada de trabalho funciona como uma aquisição de conhecimento que deve ser utilizada na venda (que para o cliente não pode parecer que é venda) da assinatura. A ansiedade é gerada pela falta de certeza da composição do salário no fim do mês. Esta certeza não pode ser construída no trabalho porque o salário depende do externo, do cliente pagar efetivamente o compromisso de assinatura assumido por telefone, e assim realmente não depende do desempenho do trabalhador. O importante aqui, a nosso ver, é compreender que todos os trabalhadores entrevistados compreendem, e sentem, as exigências do trabalho, independente de apresentar fadiga ou não na Escala de Chalder. 


\section{(1) Tema: Fatores Associados à Determinação da Fadiga (SA)}

Quadro 11 - Comparação dos discursos dos trabalhadores do SA, com e sem fadiga, sobre o tema de Fatores Associados à Determinação da Fadiga.

\begin{tabular}{|c|c|}
\hline Trabalhadores com fadiga & Trabalhadores sem fadiga \\
\hline - Tem dia que força muito, tem dia que não. & $\begin{array}{l}\text { - Tem dia que parece que você se esforça } \\
\text { demais. }\end{array}$ \\
\hline - Movimento muito repetitivo. & $\begin{array}{l}\text { - Trabalha em movimento, bem repetitivo, é } \\
\text { rápido não é brinquedo não. Se trabalhar } \\
\text { devagar não acompanha a produção da } \\
\text { máquina. }\end{array}$ \\
\hline - Todo trabalho cansa. & - A gente não faz tanto esforço físico. \\
\hline - Cansa por ficar em pé durante toda a jornada. & $\begin{array}{l}\text { - A gente trabalha em gaveta, saída, o operador } \\
\text { não tem para onde ir. }\end{array}$ \\
\hline • Muito tempo em uma posição só. & - Trabalhando o dia inteiro puxando. \\
\hline - Todo mundo queria ser chefe. & $\begin{array}{l}\text { - Às vezes a carga de serviço é alta as vezes é } \\
\text { pouca, aqui é cheio de altos e baixos. }\end{array}$ \\
\hline \multirow[t]{5}{*}{ - Afastada 3 anos por tendinite. } & $\begin{array}{l}\text { - A maioria das máquinas não tem equipe } \\
\text { completa. A firma passa por vários corte, por } \\
\text { vários problemas. }\end{array}$ \\
\hline & - Você tem que desdobrar um pouquinho. \\
\hline & $\begin{array}{l}\text { - Dia de revista pesada é muito corrido, muito } \\
\text { pesado, é cruel. }\end{array}$ \\
\hline & $\begin{array}{l}\text { - A gente que é mulher tem que chegar em casa } \\
\text { e lavar, passar, preocupar com } \\
\text { responsabilidades. }\end{array}$ \\
\hline & $\begin{array}{l}\text { - Tem cálculo no rim, mioma, dor na coluna e } \\
\text { acidente de trabalho. }\end{array}$ \\
\hline
\end{tabular}

Semelhante ao STA os dois grupos não apresentam discursos que se diferenciam. A percepção da situação gerada pelo trabalho, que atua como um fator que pode está associado à determinação da fadiga, é comum a estes trabalhadores. Os dois grupos possuem também um discurso complementar. Assim, estar ou não fatigado não interfere na percepção de como $\circ$ trabalho é pesado, repetitivo, com carga variável durante a semana (altos e baixos) e realizado em postura estática durante toda a jornada de 
trabalho. O discurso apresentado de que "todo mundo quer ser chefe" pode ser um reflexo do estilo organizacional da empresa, com características do modelo clássico (Taylorista/Fordista) onde ser chefe pode representar um privilégio dentre os demais trabalhadores. Ser chefe é ter poder, é status.

\section{(2) Tema: Características Individuais}

Quadro 12 - Comparação dos discursos dos trabalhadores, com e sem fadiga, sobre o tema de Características Individuais.

\begin{tabular}{|c|c|}
\hline Trabalhadores com fadiga & Trabalhadores sem fadiga \\
\hline $\begin{array}{l}\text { - Gosta do que faz, ama o trabalho, nem que isso } \\
\text { prejudique, canse. } \\
\text { - Gosta de estar falando, o negócio é o humano, } \\
\text { não nasceu para ficar atrás de uma máquina. } \\
\text { - Respeita o corpo. } \\
\text { - Postura rígida consigo mesmo. } \\
\text { - Põe-se responsabilidade maior. } \\
\text { - Leva o trabalho a sério. } \\
\text { - Faz o trabalho ao seu modo, no seu limite. } \\
\text { - Está acostumado a dores e cansaço físico. } \\
\text {-Não se maltrata pelo problema. } \\
\text { - Não gosta de rotina, gosta de coisas diferentes, } \\
\text { de estar mudando. } \\
\text { - Não gosta de falar, guarda para si. } \\
\text { - Não consegue esperar, vai atrás. }\end{array}$ & $\begin{array}{l}\text { - Gosta do que faz. } \\
\text { - A vivência no trabalho tem trazido crescimento } \\
\text { de como conversar ou lidar com pessoas. Na } \\
\text { vida profissional tem que viver o crescimento. } \\
\text { - Esta não é função na vida, pretende ser } \\
\text { enfermeiro, jornalista, advogada, trabalhar com } \\
\text { marketing. } \\
\text { - Seu ritmo é acelerado, é super ativa, gosta de } \\
\text { serviço rápido, de trabalhar em movimento. } \\
\text { - É assim um pouco caxias. } \\
\text { - É uma pessoa tranqüila bem calma. } \\
\text { - Não fica desesperada, fica preocupada. } \\
\text { - Tem aprendido a respeitar seus limites. } \\
\text { - Regras são regras não tenho dificuldades. } \\
\text { - Se errar tenho que assumir o erro. } \\
\text { - Tirando a dor já está ótimo, eu agüento. } \\
\text { - Faz tudo certinho suas coisas. }\end{array}$ \\
\hline
\end{tabular}

No quadro 12 as características individuais dos trabalhadores sem fadiga mostram que estes têm anseios além do trabalho atual, querem fazer 
algo na vida que não seja aquele trabalho alí desenvolvido. Por exemplo, querem seguir uma carreira profissional (jornalista, advogado, etc.). Vêem o trabalho no STA, por exemplo, como uma passagem para alcançar outros ideais. Se apresentam como pessoas calmas, tranqüilas, que não se desesperam, aceitam regras sem questioná-las, trabalham em ritmo acelerado, gostam de movimento, de trabalhar rápido e como "caxias". São formas de comportamento diante do trabalho. Reflexo da maneira de ser de cada um. Essas atitudes parecem indicar uma maior aceitação das coisas como elas são, mas de um modo a fazer disso um "trampolim" para uma vida profissional melhor. Tem um ponto comum que é gostarem do que fazem, ou seja, gostar do trabalho.

Diferentemente deste grupo, apesar de relatarem gostar do que fazem, o discurso dos trabalhadores com fadiga mostra características que não condizem com o trabalho escolhido (ou levado a escolher) como, por exemplo, não gostar de máquina, mas do ser humano, não gostar de rotina, mas de coisas diferentes, não gostar de falar. Esses discursos são importantes como caracterização porque na descrição do trabalho observado e de acordo com as falas presentes nos discursos, o trabalho é repetitivo (rotineiro, monótono - faz-se sempre a mesma coisa), sem mudanças frequentes e desenvolvido através do uso de uma máquina, seja na grampeadeira ou no computador. Alem disto é um trabalho realizado por pessoas que indicam ter uma postura rígida consigo mesmo e estar acostumado a dores e cansaço. Esta questão de "costume" é uma expressão de quem tem a dor e cansaço que dificilmente irá aparecer em quem não a tenha.

A apresentação dos discursos nos leva a crer que há uma diferença nos relatos sobre si entre os dois grupos, com e sem fadiga. 


\section{(3) Tema: Identificação da Situação Problema}

Quadro 13 - Comparação dos discursos dos trabalhadores, com e sem fadiga, sobre o tema de Identificação da Situação Problema.

\begin{tabular}{|c|c|}
\hline Trabalhadores com fadiga & Trabalhadores sem fadiga \\
\hline $\begin{array}{l}\text { - Durante o mês fica tensa, você sente isso no } \\
\text { físico. Final do mês cansa, acabando o mês } \\
\text { sente alivio e o corpo descansa. }\end{array}$ & $\begin{array}{l}\text { - Às vezes fica sem voz e a ferramenta de } \\
\text { trabalho é a comunicação. }\end{array}$ \\
\hline - Fico cansada de tanto levar "não" pelo telefone. & - Fica desgastado.. \\
\hline $\begin{array}{l}\text { - Tem dia que o estresse é grande no setor e } \\
\text { agente sai com a cabeça cheia, cansado. }\end{array}$ & $\begin{array}{l}\text { - É cansativo pelo red fone, pelo horário e pelos } \\
\text { clientes que chegam a ser grosseiros. }\end{array}$ \\
\hline $\begin{array}{l}\text { - Não consigo pagar as contas e vai fazendo uma } \\
\text { transferência para o corpo e sensação de } \\
\text { cansaço eu acho da rotina. }\end{array}$ & $\begin{array}{l}\text { - Cansativo porque trabalha de } 8 \text { às } 14 \text { sem } \\
\text { parada, nåo pode relaxar. }\end{array}$ \\
\hline $\begin{array}{l}\text { - A preocupação e o estresse mental acaba } \\
\text { influenciando no seu cansaço. }\end{array}$ & $\begin{array}{l}\text { - Cansativo porque fica muito tempo fechado na } \\
\text { frente do computador. }\end{array}$ \\
\hline $\begin{array}{l}\text { - O trabalho digitando, da rotina acho que traz } \\
\text { alguma coisa para o físico. }\end{array}$ & - Faz leitura de mais de 150 revistas por mês. \\
\hline - O momento que sinto cansada depende do dia. & $\begin{array}{l}\text { - Quem trabalha com vendas é um pouco } \\
\text { inseguro. }\end{array}$ \\
\hline $\begin{array}{l}\text { - Tem pessoas que tem problema de coluna que } \\
\text { a gente trabalha no abaixa-levanta. }\end{array}$ & - Um trabalho que foge ao controle. \\
\hline $\begin{array}{l}\text { - A gente trabalha de pé o dia inteiro, só força, } \\
\text { então é uma canseira. }\end{array}$ & $\begin{array}{l}\text { - O que eu faço muita gente, que pelo tempo que } \\
\text { está aqui não gosta de fazer. }\end{array}$ \\
\hline $\begin{array}{l}\text { - Qualquer coisinha me irrita acho que seria o } \\
\text { estresse. }\end{array}$ & $\begin{array}{l}\text { - O pessoal tem bastante tendinite, é a parte de } \\
\text { ser repetitivo, trabalho só os braços. }\end{array}$ \\
\hline \multirow{2}{*}{$\begin{array}{l}\text { - Tem que estar com a alma preparada para o } \\
\text { corpo agüentar o trabalho. }\end{array}$} & - É um cansaço de gosto de trabalhar. \\
\hline & - Quando está trabalhando é um cansaço normal. \\
\hline
\end{tabular}

Nos dois grupos a situação vivida no trabalho é identificada como problemática, pois traz reflexos para o corpo e faz com que se sintam cansados. $O$ discurso dos dois grupos nos parece mais complementar do que oponente. Uma referência interessante no grupo de trabalhadores sem fadiga é de que o trabalho pode gerar um cansaço de "gostar de trabalhar", um cansaço bom. 
No grupo de trabalhadores com fadiga, além de detectar o problema do cansaço, os trabalhadores ainda o localizam dentro do tempo, numa sequência cronológica durante o trabalho no mês, ou seja, ficam tensos durante o mês e cansados no final do mês. Entendemos que conforme o desenvolvimento das vendas durante o mês estas podem atuar como um fator predisponente ao aparecimento do cansaço no final do cumprimento de metas. Uma fala dos trabalhadores indica que o tempo de serviço (na função) pode determinar o envolvimento com a tarefa, ou seja, inclui o gostar ou não de exercê-la ou fazer com empenho mesmo que não goste. $O$ exemplo é encontrado na fala onde os trabalhadores que estão a mais tempo no trabalho não gostam de fazer aquela determinada tarefa, deixando para quem é mais novo de casa, com um menor tempo de serviço. É interessante que o trabalhador mais novo faz a tarefa sem considerá-la um problema, pelo menos no momento da pesquisa. 


\section{(4) Tema: Expressão da Fadiga}

\section{Quadro 14 - Comparação dos discursos dos trabalhadores, com e sem fadiga, sobre o tema de Expressão da Fadiga.}

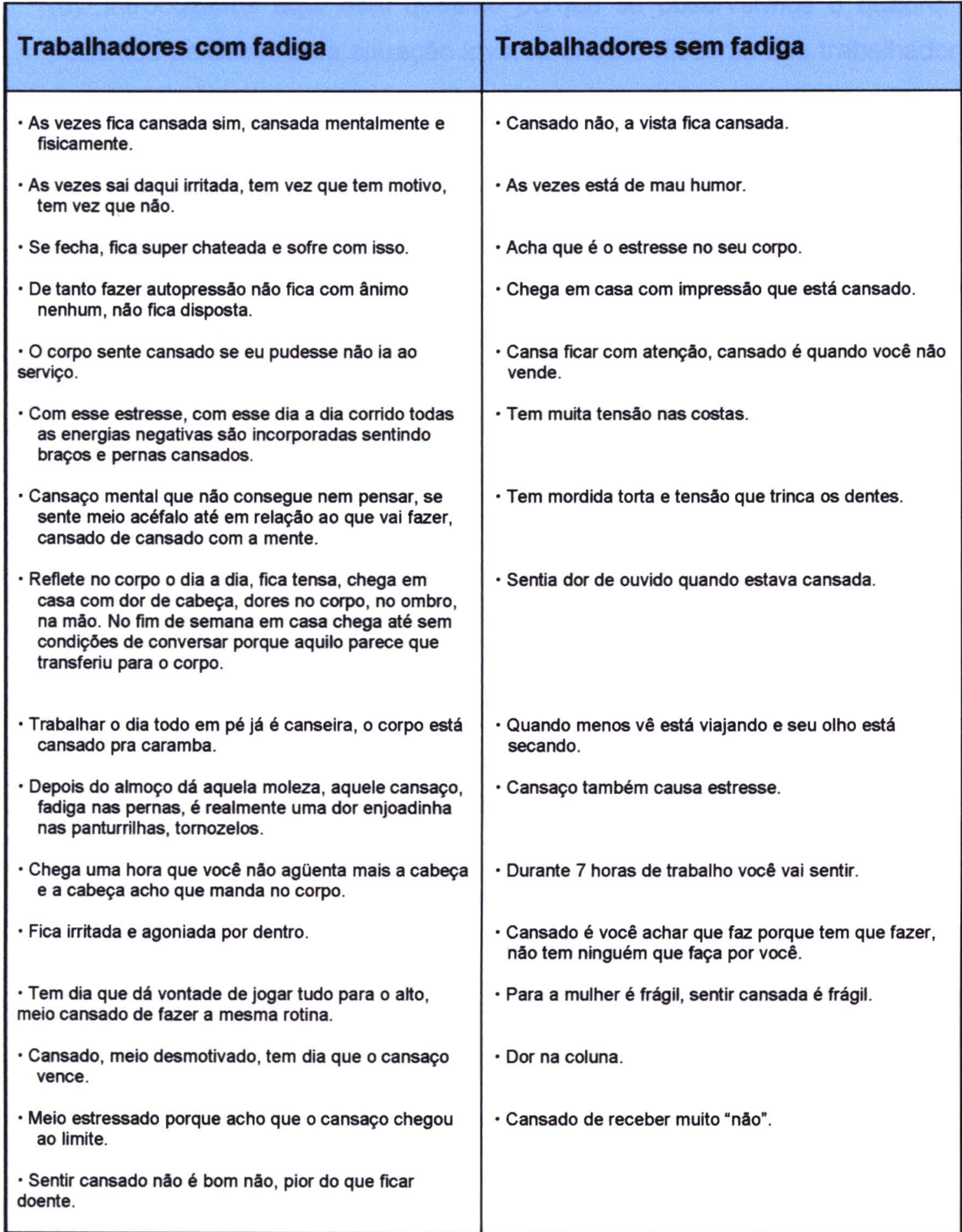

Pode ser observado que nos temas anteriores o discurso dos trabalhadores sem fadiga é mais longo, no sentido de conter um maior 
número de referências, do que o dos trabalhadores com fadiga. Esta é a situação esperada, uma vez que o número de trabalhadores entrevistados que não apresentaram fadiga (15) é maior do que o dos que a apresentaram (8). Introduzimos aqui esta questão porque se observarmos o quadro 10 podemos perceber uma situação inversa onde o discurso dos trabalhadores com fadiga é mais extenso do que o dos trabalhadores sem fadiga. Talvez o inesperado aqui seja o fato do trabalhadores falarem sobre a fadiga sem apresentarem a fadiga na Escala de Chalder. Voltando a nossa consideração de que a sensação de cansaço é um sinônimo de fadiga podemos observar, no quadro 12 , que mesmo os trabalhadores que não apresentaram fadiga discursam sobre esta sensação.

A expressão da fadiga no discurso dos trabalhadores com e sem fadiga aparece de maneira diferente. Há a utilização de fatos objetivos no discurso, tais como a alusão a uma dor na coluna, dor nos ombros, braços, mãos e dores no corpo, pernas cansadas, dor de cabeça, mordida torta que trinca os dentes, tensão nas costas, estresse no corpo, vista cansada e dor de ouvido. Além disso, foi citada também a questão de ser mulher e ter a jornada de trabalho doméstico. A sensação de cansaço foi mais explorada pelo grupo que apresentou fadiga. Neste grupo é importante observar a referência constante ao cansaço mental, sem desprezar o cansaço físico, mas reforçando o mental e considerando que a cabeça cansa e esta manda no corpo.

O discurso nos parece complementar entre o grupo de fatigados e de não fatigados. 
(6) Tema: Estratégias de Enfrentamento da Fadiga

Quadro 15 - Comparação dos discursos dos trabalhadores, com e sem fadiga, sobre o tema de Estratégias de Enfrentamento da Fadiga.

\begin{tabular}{|c|c|}
\hline Trabalhadores com fadiga & Trabalhadores sem fadiga \\
\hline $\begin{array}{l}\text { - Levanta, vai dar uma volta, beber água, lavar o } \\
\text { rosto. } \\
\text { - Procura chegar em casa e sair, espairece, } \\
\text { esquecer, viajar. } \\
\text { - Estando em casa aluga filme, chama os amigos } \\
\text { para jogar baralho, etc, que isso faz a gente } \\
\text { esquecer totalmente o serviço. } \\
\text { - Descansar é fugir um pouco, é o fim de semana. } \\
\text { - Tem que fazer, levar da maneira que der. Se vê } \\
\text { que não está dando para fazer tudo, então } \\
\text { pega a metade, põe lá, depois vai levando, } \\
\text { pega outra metade e assim vai. } \\
\text { - Procura mudar um pouco as coisas, mudar de } \\
\text { lugar senão se cansa. } \\
\text { - Trabalhando você se distrai, você não está } \\
\text { vendo o que está sentindo. Quando você para } \\
\text { começa a aparecer um monte de dor. } \\
\text { - Nem todo dia estamos de bom humor. Saber } \\
\text { levar isto tudo numa boa é saber conduzir a } \\
\text { situação. } \\
\text { - Tem que estar com a alma preparada para } \\
\text { poder suportar aquele instante, para o corpo } \\
\text { agüentar o trabalho. }\end{array}$ & $\begin{array}{l}\text { - Se está cansado quando chega na empresa é } \\
\text { uma motivação. } \\
\text { - Sai de vez em quando, vai ao banheiro, lava o } \\
\text { rosto, toma água, fuma, pensa um pouquinho, } \\
\text { toma café, dá uma espairecida. } \\
\text { - Controlar um pouco. } \\
\text { - Aprender a lidar com a insegurança. } \\
\text { - Problemas não existem se existem tem que } \\
\text { resolvê-los hoje, não deixar para amanhã, } \\
\text { porque amanhã é outro dia. } \\
\text { - Presta atenção. } \\
\text { - Pensar que não precisa do trabalho só hoje, } \\
\text { precisa dele por muito tempo. } \\
\text { - Faz ginástica no trabalho, faz acupuntura e } \\
\text { meditação. } \\
\text { - Está subindo para estar crescendo. } \\
\text { - Não criticar, não reclamar porque ninguém } \\
\text { gosta de ser criticado. }\end{array}$ \\
\hline
\end{tabular}

Como pode ser observado no quadro 15, o grupo sem fadiga apresenta um discurso sobre tomadas de decisões quanto ao que fazer para melhorar a sua situação de cansaço ou exposição a fatores associados à fadiga como, por exemplo, fazer acupuntura, fazer meditação, fazer ginástica 
no trabalho, tirar férias como um remédio: "para curar de vez". Assim o grupo sem fadiga mostra estratégias mais elaboradas de enfrentamento, mais concretas e precisas. Estes trabalhadores parecem estar centrados no seu modo de ser. Aparece o "controlar um pouco", "aprender a lidar com a insegurança", "não jogar a toalha em si mesmo", "os problemas têm que ser resolvidos hoje e não amanhã" e "os problemas não existem". Uma questão interessante no discurso dos trabalhadores sem fadiga é de que o cansaço funciona como uma motivação.

Em relação às expressōes subjetivas, os dois grupos as apresentam, mas o grupo com fadiga apresenta ou uma estratégia de fuga, ou uma estratégia de manter a mente ocupada para não pensar na situação vivenciada. Eles discursam que é necessário lidar com a variação do humor, estar com a alma preparada para poder suportar o trabalho. "Descansar é fugir". Também temos a indicação do trabalho funcionando como uma distração para não sentir o que realmente o corpo está mostrando (ou indicando): que ele está cansado. Por outro lado tem-se que fazer o trabalho, levar da maneira que dá. 


\section{DISCUSSÃO}

\subsection{A Medida da Fadiga}

Os resultados da Escala de Fadiga de Chalder mostraram a prevalência da fadiga no grupo pesquisado. De uma maneira geral, o grupo de trabalhadores $(n=200)$ apresentou uma prevalência de $37,5 \%$ de fadiga. Esta estimativa pode ser comparada com a prevalência em estudos citados por Wessely et al (1998) que variam de $27,0 \%$ na população do Reino Unido, $26,2 \%$ na população alemã a $16,0 \%$ na população finlandesa. Quando se verifica a prevalência estimada por sexó na presente pesquisa obtivemos $35,9 \%$ em homens e $41,8 \%$ em mulheres. Nas pesquisas citadas por Wessely et al a prevalência na população no Reino Unido foi de $22,0 \%$ em homens e $33,0 \%$ em mulheres. Nos Estados Unidos, a prevalência foi de $14,3 \%$ em homens e $20,4 \%$ em mulheres. Algumas das pesquisas citadas por Wessely et al (1998) mostram prevalências de $29,3 \%, 28,5 \%$ e $33 \%$ em homens e $36,7 \%, 44,6 \%$ e $47,5 \%$ em mulheres, respectivamente. 0 estudo de Besing et al (1999) também aponta uma prevalência de $37,8 \%$ em mulheres versus $24,3 \% \mathrm{em}$ homens. As prevalências encontradas nesta pesquisa, de uma certa forma se aproximam das encontradas na literatura. $E$ claro que as variações são decorrentes das diferenças nos critérios usados e das características das amostras que diferem marcadamente entre os estudos. Os dados de prevalência encontrados nesta e nas outras pesquisas servem apenas como indicativos, uma vez que as definições, instrumentos e amostras são diferentes e, portanto, os dados não podem ser vistos como diferenças absolutas entre populações.

Uma diferença fundamental entre esta pesquisa e os referidos estudos sobre a fadiga em populações é que a amostra desta pesquisa vem de uma população trabalhadora e não da população geral. Portanto, deve-se ter cautela ao comparar os resultados encontrados aqui com os de estudos populacionais. Além disso, deve-se ter em mente que na utilização de amostras de uma população trabalhadora tem-se que levar em conta o 
"efeito trabalhador sadio". O fenômeno ocorre porque os indivíduos relativamente sadios são provavelmente os que conseguem estar empregados e se manter no emprego. Este fato pode estar subestimando a taxa de prevalência encontrada, que pode ser mais elevada quando se considera a população em geral.

O que é comum entre os resultados obtidos e os encontrados na literatura é que a prevalência de fadiga é maior entre as mulheres. Isto pode ser decorrente da dupla jornada desempenhada pelas mulheres. A maior taxa de prevalência da fadiga entre as mulheres recebe um peso maior do STA onde a taxa de prevalência é $32,5 \%$ enquanto que no SA a taxa de prevalência nas mulheres é de apenas $6,3 \%$. Istó reflete a política de pessoal implementada no SA onde o trabalho requer o uso de força e há uma opção pela contratação de homens em detrimento das mulheres.

Quanto à fadiga crônica o estudo apresenta uma prevalência de $7,0 \%$ para a população estudada ( $\mathrm{N}=200$ ), com uma prevalência de $5,5 \%$ entre homens e $10,9 \%$ entre mulheres. A prevalência da fadiga crônica em uma população de bancários em um banco estatal brasileiro, encontrada por Souza (2002) foi de $8,7 \%$ ( $n=735$ ), sendo de $7,8 \%$ entre homens e $11,0 \%$ entre mulheres. Comparando-se as taxas de prevalências encontradas com as encontradas no estudo de Souza observa-se uma proximidade na prevalência entre homens e uma prevalência praticamente igual para as mulheres $(10,9 \%$ versus $11,0 \%)$.

O estudo também apontou que ser casada pode ser um fator determinante, principalmente nas mulheres. A prevalência de fadiga é maior para as mulheres do que para os homens neste e em outros estudos da literatura. Os resultados mostraram também que as mulheres casadas apresentam uma maior taxa de prevalência de fadiga do que as solteiras. Ser casada para as mulheres deve ser um fator determinante, uma vez que o casamento traz exigências domésticas maiores para as casadas quando comparadas com as solteiras. A questão da dupla jornada fica acrescida de tarefas domésticas relacionadas ao cuidado dos filhos. A rotina do cuidar da casa e das tarefas do lar tem socialmente sido delegada às mulheres e 
poupado os homens, cujo papel tradicional é o de sustentar a familia através de seu trabalho. O trabalho masculino é socialmente visto como árduo e cansativo, sendo que os homens devem ter o "merecido" descanso ao chegar em casa. A inclusão das mulheres no mercado de trabalho nos últimos anos não as tem poupado igualmente da tarefa doméstica. Além do trabalho doméstico em si, arrumar a casa, lavar, passar, cozinhar, soma-se o cuidar dos filhos. No estudo de Bessing et al (1999) foi apontado uma alta prevalência de fadiga $(42,2 \%)$ entre mulheres cuja jornada de trabalho combina o emprego e o cuidar de crianças jovens. No presente estudo não podemos discutir o cuidar de crianças e o trabalho doméstico por não se ter pesquisado estes aspectos, até porque não era o enfoque principal da pesquisa, mas é importante apontar o fato de ser casada como um fator agravante da condição de fadiga profunda, conforme medido pela Escala de Chalder. Por outro lado, ser casado para os homens pode estar agindo como um fator de proteção contra a fadiga.

\subsection{A Questão dos Instrumentos}

A questão da aplicação de um questionário, com perguntas direcionadas pode representar uma interferência na interpretação posterior dos dados. Isto porque são oferecidas respostas fechadas sobre determinado tema, construídas a partir de um entendimento comum que os pesquisadores têm sobre fadiga. Existem respostas pré-definidas que classificam 0 indivíduo como provável portador ou não do problema. Conforme já discutido, a fadiga percebida ou sensação de fadiga tem sido pesquisada por questionários ou escalas com perguntas direcionadas que partem de parâmetros definidos tendo os sinais e sintomas como base para a determinação da presença ou ausência de fadiga. Geralmente, os itens são avaliados por escores que dão a indicação da existência da fadiga. Nesta pesquisa foi aplicado um destes instrumentos, a Escala de Fadiga de Chalder. No entanto, os resultados mostraram que o instrumento não vai além da indicação do problema. $O$ que se costuma fazer nas pesquisas é 
associar os instrumentos a variáveis que caracterizam o indivíduo e nas análises, dependendo da representatividade da população estudada, indicar associações da existência da fadiga com variáveis que se somam ou apresentem fatores determinantes para a ocorrência do fenômeno. A Escala de Fadiga de Chalder, assim como outros instrumentos desta natureza, funcionam como uma "fotografia", um mapa de detecção da presença de um estado funcional: a fadiga. $O$ instrumento por si só não permite uma análise que vise delimitar ou descrever o fenômeno fadiga, assim como ela ocorre no individuo, até porque a própria idéia da quantidade não permite 0 entendimento do individuo a não ser como um número no coletivo pesquisado. Esta questão é importante para não se perder de vista qual é a análise que $o$ instrumento permite.

Durante a aplicação dos questionários foi observado que os trabalhadores expressavam sempre sua dificuldade em interpretar o que é "menos que o habitual" e "muito menos que o habitual". Alguns trabalhadores interpretavam essas categorias de resposta como "não sentir a situação apontada", mas com uma diferença em relação a elas na direção do passado, a categoria mais branda "menos que o habitual" era interpretada como tendo sentido o problema antes, mas que hoje ele não existe mais, ou diminuiu. Isto mostra que em um questionário fechado, as respostas às questões dependem da interpretação do indivíduo que pode não ser a mesma, e provavelmente não é, que a do pesquisador ou planejador do questionário. Este também é o caso de trabalhadores que não encontraram a resposta que queriam e criaram uma nova resposta: "não".

Uma diferença ocorrida no questionário e no instrumento qualitativo foi a questão dos sintomas indicados no questionário e os sintomas relatados no discurso dos trabalhadores. Nas respostas ao questionário os itens mais freqüentemente apontados pelos respondentes foram a "necessidade de mais descanso" (46,0\%), "sentindo com sono ou sonolento" $(39,7 \%)$, "sentindo cansado" (38,5\%) e "fraqueza nos músculos" $(29,5 \%)$. Outros itens com freqüência que devem ser consideradas foram as questões referentes a "dores musculares" $(29,0$ e $27,0 \%)$ e "falta de energia" $(25,5 \%)$. 
Se considerarmos as origens dos sintomas, levando em consideração a divisão proposta pelo questionário, poderíamos dizer que as respostas foram mais centradas, teve uma maior freqüência, nos sintomas físicos do que nos sintomas mentais e até a questão da dor muscular foi mais referida do que os sintomas mentais. Pode-se pensar que este fato tem uma relação com a percepção do individuo que o leva a sentir com mais rapidez e facilidade uma dor localizada em um músculo, sentir sono ou sonolência, do que perceber ou sentir uma dificuldade de memorização ou concentração. Esta é uma questão não rastreada pela Escala de Fadiga de Chalder. É importante nesta situação conhecer o indivíduo e entender como e quais são os sintomas presentes que concorrem para o aparecimento da fadiga. Talvez para estas repostas na entrevista deva-se deixar, ou até pedir que o individuo recorra à sua experiência vivida para poder expressar com maior clareza seus pensamentos em relação aos sintomas.

Os resultados mostram uma diferença nas análises, pois um dos fatores no questionário com maior freqüência de respostas, o "estar com sono ou sonolento", não aparece na entrevista na abordagem qualitativa como um sintoma importante de fadiga. São abordagens diferentes, mas um aspecto importante deve aparecer em qualquer circunstância em que se trate do tema. A questão sobre a necessidade de descanso não aparece claramente na abordagem qualitativa, mas sim subjetivamente quando 0 trabalhador refere que vai tirar férias para curar de vez ou descansar é fugir um pouco, é o fim de semana.

Em relação à questão aberta sobre os motivos de sentir cansado também aparecem respostas mais freqüentes relacionadas ao sono ou sonolência, as causas advindas da forma como o trabalho está organizado, as doenças e dores e as causas psíquicas, responsabilidades, ansiedades ou conflitos. Há uma diferença na freqüência de respostas: as causas ligadas à ansiedade (causas psíquicas) e responsabilidade apresentaram uma menor freqüência para o STA do que para o SA. A responsabilidade citada neste item tem relação com a vida pessoal, familiar. As 
responsabilidades têm relação com os baixos salários e as dívidas. As responsabilidades com o trabalho não obtiveram referências.

Uma questão a ressaltar é o entendimento comum do que é cansaço. Este é percebido, e facilmente entendido, pelos trabalhadores, pois mesmo entre os trabalhadores que não se classificaram como fatigados pela Escala de Chalder houve respostas do porque se sentem cansados.

Outra questão importante é a relação dos sintomas físicos e os sintomas mentais. Se recorrermos às diferentes características do trabalho levantadas pela análise das condições de trabalho, pode-se perceber que o trabalho no SA tem um forte componente centrado na exigência física: levantamento e carregamento de peso, movimentos repetitivos realizados durante toda a jornada de trabalho com permanência na postura em pé. Isto é apontado não só pela análise como pelo discurso dos trabalhadores: porque tudo que vai fazer tem que fazer movimento repetitivo, só o dia de revista pesada que é muito pesado, cruel pra gente ou o problema é estar de pé, você fica muito tempo em uma posição só. Neste setor, por estas características, pode-se justificar a maior indicação de respostas para os sintomas físicos. Já no STA a análise das condições de trabalho apontou para um forte componente mental na atividade. A exigência mental/cognitiva é grande e oriunda da forma como o trabalho está organizado. As exigências de cumprimento de metas e o tipo de remuneração são fatores que sobressaem para criar uma condição de trabalho sob ansiedade e angústia. Os trabalhadores também lidam com várias informações que devem ser armazenadas no cérebro para serem empregadas quando exigidas no momento da venda. Com referência à situação vivenciada pelos trabalhadores os efeitos do trabalho poderiam estar indicando sintomas relacionados à área mental. Os trabalhadores revelam em seus discursos esta carga mental: você precisa ficar "tensionado" com o cliente, exige atenção e responsabilidade, às vezes você fica cabisbaixo em relação a determinados clientes que te atendem mal, eu acho que é uma pressão necessária para o departamento, mas pesada para quem exerce a função, de tanta autopressão não fico com ânimo nenhum nem fico disposta, 
cansaço mental, cansado com a mente, me sinto meio acéfalo. Talvez o que prejudique o entendimento do problema na Escala aplicada é sua separação entre aspectos físicos e mentais. Esta separação entre corpo e mente não é uma abordagem adequada. O discurso dos trabalhadores nos aponta com clareza a junção entre o corpo e a mente: reflete no corpo o dia a dia, fico tensa, chego em casa com dor de cabeça, dores no corpo, no ombro, na mão, no fim de semana chego em casa até sem condições de conversar porque parece que aquilo transferiu para o corpo.

Os instrumentos de medida de fadiga $e o$ instrumento utilizado nesta pesquisa (Chalder et al, 2000) foram elaborados partindo-se dos conhecimentos empiricos sobre a ocorrência de fadiga na população. As perguntas incluídas nos instrumentos seguem as idéias sobre os diversos componentes de fadiga propostos por Bartley e Chute (1947), Grandjean (1988), e outros. A divisão em sintomas físicos e mentais visa abarcar a complexidade do fenômeno fadiga, as várias faces do problema. Mas quando nos deparamos com um fenômeno com tal complexidade, é provável que aspectos do fenômeno não se adequem a uma abordagem simplista. Realmente não existe uma separação entre fatores determinantes de sintomas físicos e mentais. Neste sentido o conhecimento sobre o trabalho, visando definir suas características básicas é necessário para entender os dados posteriores obtidos, seja por uma abordagem qualitativa ou quantitativa. Um exemplo disso é a importância da observação realizada nos setores analisados. Os trabalhadores do SA realizam um trabalho de levantamento e carregamento de peso, com abaixamento e levantamento do corpo, tronco e membros inferiores, com desenvolvimento de força, demonstrando a presença de um forte componente físico no trabalho. Mas ele também está sob uma organização do trabalho que restringe sua liberdade, sua comunicação, exige o trabalho em tarefas parceladas, o coloca sob pressão de produção, como mostra o seguinte discurso: aqui a gente só come quando o chefe tem fome. O componente físico é mais presente, mas existe um componente mental importante agregado ao trabalho. O mesmo raciocínio pode ser empregado para o STA onde a 
organização do trabalho é tal que leva a uma pressão para produção sobre o trabalhador, com metas a serem vencidas, um trabalho que aparece no discurso como: ninguém para, ninguém levanta. Por outro lado, é um trabalho realizado sentado em toda a extensão da jornada, com exigência de trabalho estático da musculatura de tronco e exigência de movimentos de membros superiores, sem apoio do cotovelo, sobrecarregando a musculatura e articulação do ombro. As exigências do trabalho são portanto tanto físicas quanto mentais, mas nesse caso, pendendo mais para as exigências mentais. No entanto, a fadiga aparece nos dois grupos de trabalhadores.

\subsection{Comparação entre os Discursos dos que Apresentam e dos que não Apresentam Fadiga}

$\mathrm{Na}$ comparação entre os trabalhadores com e sem fadiga pode-se detectar diferenças nos discursos em relação a características individuais e estratégias de enfretamento da fadiga.

Quando descrevem suas características individuais, os componentes de um grupo, por exemplo, com fadiga, apresentam características comuns diferentes das características comuns aos componentes do outro grupo, sem fadiga. O grupo com fadiga revelou características que mostram uma insatisfação geral com o trabalho que estava realizando no momento da pesquisa. Pensam em poder realizar atividades melhores que thes dê mais segurança e uma maior projeção na vida. Estamos nos referindo à questão de querer ser jornalista, advogada, enfermeiro, trabalhar com marketing. Além disso, aparece nesse grupo a característica de serem mais rígidos consigo mesmos.

Segundo as definições e idéias de Cameron (1973), Grandjean (1988) e Holding (1984) a fadiga está ligada às características individuais. Quando se estuda a fadiga deve-se levar em consideração as diferenças individuais existentes, inclusive as de natureza emocional. O componente emocional aparece quando os trabalhadores referem que gostam do que fazem, amam 
o trabalho, nem que isto os prejudique, os canse. A aceitação de situações que nos prejudicam está ligada à percepção e valores individuais, acumulados em sua vivência e aprendizagem no decorrer de sua vida.

Por outro lado, o grupo sem fadiga apresenta características que condizem com a conformidade às exigências sociais e do trabalho como, por exemplo, ser "caxias", aceitar regras sem questioná-las, assumir o erro, não precisar ninguém estar mandando, gostar de trabalho repetitivo.

A conformidade também se expressa na afirmação de gostarem do que fazem. Mas será que as pessoas realmente gostam de um trabalho repetitivo e monótono? Porque as pessoas se submetem a este tipo de trabalho? A resposta pode estar na questão social: no medo do desemprego, na necessidade de sobrevivência, discutido no âmbito da sociologia do trabalho, psicologia do trabalho e mesmo na área da saúde, pensando na dimensão econômico-social. Mas como esses fatores se refletem no indivíduo, na sua subjetividade? Se olharmos para o indivíduo enquanto uma existência singular com uma constituição física/mental como podemos entender esta questão? Parece existir uma dimensão individual que os leva a atuar desta maneira. Ou é porque realmente gostam do que fazem ou a afirmação é a expressão de uma defesa contra uma situação incômoda. Mesmo sendo um mecanismo de defesa, esse tipo de defesa não é compartilhada por todos, uma vez que alguns trabalhadores mostraram rejeição por este tipo de trabalho e outros se omitiram quanto ao fato de gostar ou não gostar.

Uma das características individuais, isolada em nossa análise do discurso dos trabalhadores, é o conjunto de estratégias de enfrentamento, contra a fadiga apresentadas pelos trabalhadores. Os resultados encontrados na análise qualitativa dos discursos dos trabalhadores mostram diferenças de estratégias de enfrentamento nos dois grupos, com e sem fadiga. Os dois grupos mostram diferenças individuais relacionadas com o tipo de estratégia adotada para enfrentar as situações de vida no trabalho e fora dele. As estratégias de enfrentamento nos remetem à teoria de Lazarus e Folkman (1984a) sobre estresse. Esses autores definem o enfrentamento, 
no caso do estresse, (coping no original) como esforços cognitivos e comportamentais em constante mudança para gerenciar demandas internas e/ou externas especificas, avaliadas como uma sobrecarga ou que excedam os recursos da pessoa. Como observado no discurso dos trabalhadores a estratégia de enfrentamento está presente e é determinada, em parte, pelo ambiente de trabalho que deve ser enfrentado. Aparece nos discursos um constante lidar com as emoções no trabalho representado por falas como: aprender a lidar com a insegurança, o cansaço é uma motivação, pensar que não preciso do trabalho só hoje, mas por muito tempo, não jogar a toalha em si mesmo, encarar a vida de frente. Os trabalhadores nestes discursos estão tentando mudar o significado da situação ameaçadora proveniente de uma condição de trabalho não satisfatória, com regras e exigências hostis ao indivíduo. São representações desenvolvidas para que se possa manter a esperança e o otimismo e recusar-se a admitir o pior: que o trabalho, o tipo de tarefa e exigências pode destruí-los enquanto individuos. Os discursos citados acima que indicam estratégias cognitivas de enfrentamento, ou seja, uma percepção da situação de trabalho que favorece o conformismo com ela, partiram de trabalhadores que não apresentam fadiga. Analisar a situação e significá-la como, por exemplo, afirmando que os problemas não existem, mas se existem temos que resolvê-los hoje, não deixando para amanhã, é uma estratégia cognitiva de enfrentamento que nega a existência de um trabalho sem sentido, como se realmente os problemas não existissem, mas deixando ainda uma segunda saída que é a possibilidade de que se eles existirem possa-se resolvê-los. Ao mesmo tempo em que se nega a existência de problemas, o individuo se coloca em uma posição onipotente, em que pode fazer qualquer coisa, só não o faz porque não há necessidade. Isto mostra o medo de não saber resolvê-los e ser vencido pelos problemas. De uma certa maneira, portanto, as estratégias de enfrentamento levam a um conformismo com a situação e a uma percepção distorcida da realidade. Essa percepção distorcida é o que leva, provavelmente, a esses indivíduos não apresentarem fadiga profunda 
na Escala de Chalder e não necessariamente o fato de não sentirem fadiga, pois a fadiga aparece no discurso na abordagem qualitativa.

Algumas características individuais presentes no discurso do grupo sem fadiga mostram uma estratégia de enfrentamento semelhante quando referem que quando chego aqui (no trabalho) o problema fica lá fora. Ao desenvolver essas estratégias de enfrentamento, os individuos sob pressão, insegurança, ansiedade, raiva, afirmações também constantes nos discursos, se esforçam em gerenciar o problema vivenciado, mas não procuram resolvê-lo.

Já o grupo de trabalhadores com fadiga também desenvolve estratégias de enfrentamento da fadiga, mas centradas em fugir da situação, ou usar o próprio problema como uma solução, ou em se preparar para enfrentá-lo. Isto pode ser percebido em afirmaçōes como descansar é fugir um pouco, trabalhando você se distrai. Neste último exemplo, a estratégia de enfrentamento adotada está no próprio trabalho, o evento causador da aflição e da angústia. Esta pode ser uma situação emocional difícil de lidar, pois se forma um ciclo vicioso gerando cada vez mais tensão. Segundo Lazarus e Folkman (1984b), em alguns eventos estressantes a energia mental é tão concentrada na ação e reação que pode levar um tempo considerável para 0 indivíduo organizar o que acontece e avaliar a sua significância. No exemplo citado anteriormente a energia mental concentrada é maior porque é necessário fazer uso dela para lidar e vivenciar a situação angustiante, aflitiva. Outra fala que demonstra o enfrentamento presente neste grupo é a de que é preciso estar com a alma preparada. Esta estratégia de enfrentamento se relaciona à antecipação da vivência do problema, mas não o nega.

Assim, a estratégia de negação do problema, da situação aflitiva e estressante que deve ser enfrentada dia após dia, leva à negação da fadiga no trabalho, a uma distorção da realidade vivenciada. Pelo contrário, a percepção da situação como aflitiva e estressante leva a estratégias de enfrentamento diferentes que não negam o problema e nesse caso, a fadiga aparece nas respostas ao questionário. 
As estratégias de enfrentamento, por outro lado, parecem estar calcadas na imagem que o indivíduo tem de si próprio, isto é, de como se descreve em termos de características individuais. Afirmaçōes do tipo sou uma pessoa tranquila, bem calma, não fico desesperada e sim preocupada, respeito meu corpo, seus limites, levam a estratégias de enfrentamento diferentes do que afirmações do tipo gosto do meu trabalho mesmo que isto me prejudique, tenho uma postura rígida comigo mesmo, não gosto de ficar atrás de uma máquina.

No discurso dos trabalhadores e suas características individuais e estratégias de enfrentamento fica evidente a relação entre os conceitos de estresse e de fadiga. No discurso dos trabalhadores o estresse é citado como uma situação vivenciada no trabalho, por exemplo, fico meio estressado porque acho que o cansaço chegou ao limite, com esse estresse, com esse dia a dia corrido, todas as energias negativas são incorporadas, sentindo braços e pernas cansados, acho que é o estresse no meu corpo. Holding (1984) define a fadiga como uma resposta generalizada ao estresse sobre um periodo de tempo e Cameron (1973) reconhece a fadiga como um problema pessoal do individuo que deve ser entendida em termos de reações do indivíduo ao estresse sobre um período de tempo. As estratégias de enfrentamento encontradas nos discursos dos trabalhadores ocorrem como uma resposta a uma situação incômoda que, por sua vez, desencadeia reações individuais, e dependendo do sucesso ou não da estratégia de enfrentamento adotada o individuo pode chegar a um quadro de fadiga, um quadro de estresse patológico ou outras doenças. As estratégias de enfrentamento acontecem dentro de um processo dinâmico e são reformuladas em função da variabilidade individual e do contexto onde ocorrem. A estratégia de enfrentamento desenvolvida é um produto de pessoas que se encontram em situações que podem ser consideradas como geradoras de estresse.

Como então podemos entender a relação entre os conceitos de fadiga e estresse? Segundo Selye (1982), conhecido na ciência médica pelos resultados de seus estudos sobre estresse, a fadiga desencadeia o estresse, 
enquanto Cameron, conhecido por seus estudos sobre a fadiga, define o estresse como um fator que desencadeia a fadiga. Essa questão requer uma revisão mais aprofundada sobre o estresse, que não era o objetivo principal desta pesquisa. $O$ estresse tem uma história semelhante à fadiga, como mostra Mikhail (1981), tão semelhante que, em um determinado período histórico, foi proposto o abandono do termo estresse. De uma certa maneira, no entanto, os resultados obtidos na pesquisa qualitativa mostram a estreita relação entre esses dois conceitos.

Lazarus e Folkman (1984a) propõe que para entender o estresse é necessário conhecer o contexto que o individuo vivencia e onde desenvolve sua estratégia de atuação. Assim, o conhecimento do ambiente contextual, no caso o ambiente de trabalho, é importante para compreender as estratégias de enfrentamento da fadiga e o adoecimento por esta morbidade. Grandjean (1988), em seu modelo sobre os determinantes da fadiga, representa a fadiga no individuo como um líquido em um tonel que vai se enchendo e determinando o grau de fadiga de um individuo, dependendo das características do ambiente e da tarefa que ele desempenha no trabalho. Para entendermos esta questão discutiremos os resultados encontrados nas observações das condições de trabalho nos dois setores.

\subsection{Condições de Trabalho}

Os resultados indicam que o aparecimento da fadiga está relacionado a fatores determinantes presentes no trabalho. Esses fatores são decorrentes dos conteúdos das tarefas e englobam questões relativas à organização do trabalho como, por exemplo, a exigência de atenção prolongada e cumprimento de metas que dependem de fatores externos, no caso, a situação financeira dos clientes, para o STA, e a velocidade imposta pela máquina, para o SA.

No caso do TA, as diretrizes da organização do trabalho têm o sentido de realizar uma pressão que deve ser apreendida como motivação, mas ocorre realmente uma pressão por vendas. Existem metas estipuladas que 
são transformadas em número de assinaturas recuperadas. A forma de remuneração tem por base a comissão que promove a "autopressão", pois os trabalhadores precisam vender para aumentar a comissão e complementar o salário fixo que é baixo. Por outro lado, a situação financeira dos clientes não é a de estar comprando (ou recomprando) as revistas e aí ocorrem muitas negativas nos contatos telefônicos. Junta-se a este quadro a responsabilidade pela venda, a ansiedade gerada no cumprimento de metas. As referências dos trabalhadores apontam para uma sobrecarga mental exatamente por esta exigência de atenção e responsabilidade continua. Interessante é que alguns trabalhadores assimilam a idéia de que esta "autopressão" é uma motivação necessária. Importante ressaltar que estamos tratando de uma "autopressão" ou autodeterminação que tem sua origem em um fator externo, gerado pela forma como o trabalho está organizado e que é internalizado pelos trabalhadores. A fala dos trabalhadores explica como funciona esse mecanismo de "autopressão":

... você senta aí na PA, você pode conversar, pode parar, tem liberdade, que eles não cobram nada. Você tem o salário e a sua comissão, então você tem que trabalhar para melhorar o seu salário que o salário é baixo, então quanto mais você vender melhor é para você. Então todo mundo pensa assim: ninguém levanta, ninguém conversa, fica todo mundo só trabalhando, trabalhando, trabalhando e acaba ficando meio estressante, porque você fica o tempo inteiro sentado ali, vendo número, e liga, e fala, aí marca.

Pode-se entender então que a citada liberdade, flexibilidade dentro do trabalho é, na verdade, a internalização das metas, deveres e valores da própria organizaçāo do trabalho. Mas é implementado de tal forma que o trabalhador acaba não tendo consciência disso. Esta situação é exatamente a descrita por Nardi et al (1999) quando afirmam ser a subjetividade do trabalhador moldada por suas condições de vida. O modo de subjetivação é tal que o sujeito se relaciona com as regras que se vê obrigado a cumprir, também as forma e se reconhece nelas. 
O trabalhador opta por uma estratégia de trabalho que reflete os valores da organização do trabalho, pois segundo sua própria fala: não vai jogar a toalha em si mesmo. É uma técnica da gerência que leva a um condicionamento de comportamento e 0 trabalhador internaliza 0 comportamento como seu, devido à sua vivência e das necessidades do emprego. Esta situação leva à ansiedade relatada pelos trabalhadores, à raiva, ao esgotamento, ao cansaço, a fadiga: ai, é horrivel quando você não consegue explicar as informações para aquele cliente. Não conseguir explicar para o cliente as promoções, a "vantagem" oferecida na renovação da revista, implica perda da assinatura e menor comissão no fechamento do mês.

No STA fica clara a presença de fatores determinantes relacionados principalmente à organização do trabalho. A forma de remuneração, por exemplo, por salário mais comissão, funciona como um incentivo a autopressão, a ansiedade por alcançar metas, ao trabalho sem pausas, que leva os trabalhadores ao seguinte discurso: todo mundo só trabalha, trabalha, ninguém conversa, ninguém para. Conhecendo o trabalho, o desenvolvimento das tarefas, podemos entender o significado de afirmações do tipo não consigo nem pensar, .... me sinto meio acéfalo, até em relação ao que devo fazer.

Para o SA os fatores determinantes estão ligados à jornada de trabalho, realizada em postura em pé em toda a sua extensão, desenvolvendo esforço e repetitividade de movimentos sob uma organização de trabalho com nítida direção centrada no modelo taylorista-fordista.

Uma questão levantada por Cameron (1973) é sobre a ação do tempo no aparecimento da fadiga. Uma condição de trabalho, tal como a encontrada nesta pesquisa, sendo repetida diariamente, mês após mês, ano após ano tem uma ação deletéria sobre o indivíduo submetido a ela. Esta é encontrada na fala dos trabalhadores: se você faz uma ou duas vezes ninguém vai sentir muito, mas durante 7 horas você vai sentir.

Os resultados encontrados aqui sobre a relação entre as estratégias de enfrentamento e $\mathrm{o}$ aparecimento da fadiga podem ser explicados pelo 
modelo teórico, neurofisiológico, da fadiga proposto por Grandjean (1988). De acordo com esse modelo, o sistema reticular de ativação está envolvido na função de regulação do sono/vigília e o sistema límbico relacionado aos aspectos da emoção, sentimento e reações comportamentais. As estruturas ativadoras do sistema reticular e dos centros de amortecimento não se tornam ativas por si só. Elas são estimuladas ou inibidas por impulsos trazidos pelas vias nervosas, incluindo as originadas no sistema límbico. As estratégias de enfrentamento estão relacionadas às emoções proporcionadas pela vivência individual $e$, portanto, têm relação com a atividade do sistema límbico. A situação de ansiedade, referida pelo coletivo de trabalhadores atuaria, portanto, sobre o sistema límbico que, por sua vez, enviaria esses sinais para o sistema reticular de ativação. 


\section{CONCLUSÃO}

A pesquisa mostrou que a fadiga, expressa como cansaço, é uma condição presente nos indivíduos, embora seja difícil defini-la. Pode-se entender a dificuldade de definir e medir a fadiga se considerarmos que 0 conceito tem sido construído dentro da tradição das ciências biomédicas e que talvez seja impossivel encontrar um lugar para um conceito como a fadiga nesse modelo que procura estabelecer parâmetros de normalidade para uma classificação posterior dos indivíduos em sadios ou doentes.

Para a fadiga, conforme já discutido, não há uma definição do que seria o normal ou o patológico. Assim, as pesquisas sobre a fadiga sofrem a falta de um parâmetro objetivo que possa avaliar diretamente o seu aparecimento, ao invés disso, as pesquisas se concentram na tentativa de entender o fenômeno sob a luz dos sinais e sintomas (abordagem clínica), até porque ele existe, necessita ser explorado e não pode ser ignorado.

Em relação ao caráter comum e freqüente da fadiga na população e especialmente nos trabalhadores, a pesquisa realizada encontrou uma alta prevalência de fadiga $(37,5 \%)$ para o conjunto de trabalhadores estudados e confirma uma maior prevalência em mulheres $(41,8 \%)$ do que em homens $(35,9 \%)$, com um maior acometimento entre as mulheres casadas. A condição de ser mulher traz consigo o papel reservado para ela na sociedade. A ela cabe cuidar da casa, dos filhos e do marido. A partir das mudanças na atuação social da mulher que vem, cada vez mais, ocupando o espaço antes reservado aos homens no mercado de trabalho, ocorre a dupla jornada, porque além do trabalho assalariado ela continua responsável pelo trabalho doméstico. Este fato é gerador de fadiga como mostra a fala das mulheres entrevistadas.

A concepção do desenho desta pesquisa sobre a fadiga teve como opção a utilização de três métodos distintos: uma abordagem quantitativa através da aplicação da Escala de Fadiga de Chalder (1973), a abordagem qualitativa utilizando a técnica de construção do discurso coletivo pautado em Lefévre et al (2000) e a técnica, também qualitativa, da análise das 
condições de trabalho, de acordo com as propostas da ergonomia. O que se pode concluir é que a adoção de métodos diferentes no estudo da fadiga de fato proporciona um melhor entendimento de sua ocorrência.

A abordagem quantitativa do fenômeno fadiga implica investigação da presença ou ausência de sinais e sintomas pré-determinados, oferecidos em uma lista de opções e se traduz em uma prevalência. Esta forma de abordar a fadiga permite detectar indivíduos que se percebem em um estado de fadiga. $O$ instrumento permite ainda pesquisar a associação da fadiga com alguns possiveis fatores determinantes presentes no instrumento. Um exemplo é a inclusão das variáveis sexo e estado civil que nos permite indicar um maior acometimento de fadiga em mulheres e maior proporção para as casadas. No entanto, a utilização deste instrumento para uma efetiva intervenção nas condições de trabalho serve apenas como um indicativo de quais situações de trabalho devem ser objetos de estudos mais detalhados.

A abordagem qualitativa da fadiga permite uma investigação mais detalhada do fenômeno. Ela permite verificar as origens da fadiga e a forma como os indivíduos criam estratégias de enfrentamento em uma situação tensa de trabalho, com pesadas exigências físicas e mentais, que representam fatores determinantes para a elaboração dessas estratégias e 0 surgimento da fadiga. Os sinais e sintomas permanecem como expressão da fadiga, mas a abordagem qualitativa permite partir para o entendimento da fadiga não limitado a estes indicadores. O fenômeno fadiga, como outros fenômenos biológicos complexos, necessita de uma abordagem qualitativa, pois não se restringe a uma definição do que é normal e do que é patológico, como preconizado pelo modelo biomédico tradicional.

$\dot{E}$ inegável que as duas abordagens permitiram um entendimento das dificuldades inerentes ao estudo da fadiga e as dificuldades de abordar 0 conceito com um único método. A pesquisa mostrou que nenhum dos dois métodos, isoladamente, permite visualizar a complexidade do fenômeno e que o fenômeno se apresenta de forma diferente dependendo do método de abordagem, conforme nossa hipótese inicial. Esta diferença ocorre porque 
as informações obtidas sobre a presença da fadiga por um instrumento quantitativo, se restringem às idéias preconcebidas sobre o fenômeno, pois os instrumentos são construídos a partir do conhecimento dos pesquisadores da área médica sobre ele, ou seja, "o que se quer saber" do fenômeno é delimitado na própria coleta dos dados. $O$ fenômeno fica restrito a uma fadiga profunda, uma fadiga crônica ou à não fadiga, no caso do instrumento utilizado aqui. Variações sobre o problema não têm espaço para aflorarem. Pelo contrário, quando se faz uso de um instrumento qualitativo, o indivíduo tem espaço livre para expressar seus sentimentos sobre o problema. Nesse último caso, a sensação de fadiga se expressa em cansaço, dor, ansiedade, e outros. A abordagem permite também o aparecimento das estratégias de enfrentamento da situação, estratégias essas que podem estar por trás da classificação de não fadiga em uma situação de trabalho que se mostra potencialmente geradora de fadiga.

A análise das condições de trabalho permite, por sua vez, localizar os fatores determinantes dos sinais e sintomas investigados pelo método quantitativo e entender a origem dos discursos originados no método qualitativo. Conhecer a situação de trabalho, a atividade, a tarefa e a organização do trabalho permite relacionar os dados individuais, subjetivos, com a situação objetiva vivida pelos trabalhadores.

Outro papel importante da observação do trabalho está no conhecimento necessário para possíveis mudanças nas condições de trabalho com o objetivo de modificar o quadro de prevalência de fadiga e amenizar o esforço requerido nas habilidades evocadas na construção das estratégias de enfrentamento.

O trabalho como um todo indica a necessidade de uma abordagem ampla do fenômeno fadiga. Apenas o instrumento quantitativo não mostra 0 fenômeno como ele pode estar se expressando para além das perguntas fechadas. Uma abordagem mais ampla, que também explore as questões individuais subjetivas como propõe Cameron (1973) parece ser mais efetiva na compreensão das várias faces do problema. 
Se o objetivo principal do estudo da fadiga no trabalho é diminuir ou eliminar sua ocorrência entre os trabalhadores, não se pode prescindir do conhecimento das reais condições de trabalho. Se não entendermos as diferenciações das cargas físicas e mentais presentes no ambiente de trabalho como poderemos atuar preventivamente? Se não conhecemos um ou outro componente nossa ação pode ser prejudicada ou até mesmo inútil para solucionar o problema em questão, ou seja, para prevenir a ocorrência da fadiga. 


\section{REFERÊNCIAS BIBLIOGRÁFICAS}

Ahonen M, Launis M, Kuorinka T. Ergonomic Workplace Analysis. Ergonomic Section Finnish Institute of Occupational Health; 1989.

Åhsberg E, Gamberale F. Perceived fatigue during physical work: an experimental evaluation of fatigue inventory. Int $J$ Ind Ergon 1998; 21: 117-131.

Åhsberg E, Gamberale F, Gustafsson K. Perceived fatigue during after mental work: an experimental evaluation of fatigue inventory. Ergonomics 2000; 43 (2): 252-268.

Ånsberg, E, Dimensions of fatigue in Different working populations. Scand J Psychol 2000; 41: 231-241.

Åkerstedt T, Lnadstrom U. Wokplace countermeasures of night shift fatigue. Int J Ind Ergon 1998; 21: 167-178.

Aulete C. Dicionário Contemporâneo da Língua Portuguesa. Rio de Janeiro: editora Delta S.A.; 1964. v.2.

Baidya KN, Stevenson MG. Local muscle fatigue in repetitive work. Ergonomics 1988; 31(2): 227-239.

Besing JM, Hulsman RL, Karlein MG. Gender differences in fatigue. Medical Care, 1999; 37 (10): 1078-1082

Beurskens AJHM, Bultmann U, Kant I, Vercoulen JHMM, Bleijenberg G, Swaen GMH. Fatigue Among Working People: validity of a Questionnaire Measure. Occup Environ Med 2000; 57: 353-357.

Bicalho LC. Karı Marx - O Capital: resumo literal, condensação dos livros 1, 2 e 3. Ed Novos Rumos Ltda, sd. p.3-4.

Binaschi S, Albonico G, Gelli E, Grassi M, Morelli di Popolo MR. Lavoro e Soggettività Della Fática. La Medicina Del Lavoro 1982; 4: 420-433.

Borg G. Escalas de Borg para a Dor e o Esforço Percebido. São Paulo: Ed. Manole, 2000. p.3-6.

Brasil. Consolidação das Leis do Trabalho. $27^{a}$ ed. São Paulo: Ed. Saraiva, 2000. pg 90.(Série Legislação Brasileira)

Cameron C. Fatigue problems in modem industry. Ergonomics 1971; 14 (6): $713-$ 720.

Cameron C. A theory of fatigue. Ergonomics 1973, 16 (5): 633-648.

Chaffin DB. Localized muscle Fatigue - Definition and Measurement. J Occup Med 1973; 15 (4): 346-354. 
Chaffin DB, Andersson GBJ, Martin BJ. Biomecânica Ocupacional. Belo Horizonte: Ergo Editora Ltda; 2001.p. 43

Chambers EG. Industrial fatigue. Occup Psychol 1961; 35 (1-2): 44-57.

Chalder T, Berelowistz G, Pawlikowska T, Watts L, Wessely S, Wrigth D, Wallace P. Development of a Fatigue Scale. J Psychosom Res 1993; 37 (2): 147-153.

Christensen $\mathrm{H}$. Muscle activity and fatigue in the shoulder muscies of assembly-plant employees. Scand J Work Environ Health 1986;12: 582-587.

Crawford A. Fatigue and Driving. Ergonomics 1961; 4: 143-154.

Ellis AC, Shipe MM. A Study of the Accuracy of the Present Methods of testing Fatigue. Am J Psychol 1903; 14: 233-245.

Ferreira ABH. Dicionário Aurélio Básico da Língua Portuguesa. São Paulo: Editora Nova Fronteira; 1994-1995.

Fialho F, Santos N. Manual de Análise Ergonômica no Trabalho. Curitiba: Genesis Editora; 1995. p.17

Grandjean E. Fatigue: Its Physiological and Psychological Significance. Ergonomics 1968; 11(5): 427-436.

Grandjean E. Fatigue in Industry. Br J Ind Med 1979; 36: 175-186.

Grandjean E. Fitting the Task to the Man - A textbook of Occupational Ergonomics. London: Taylor \& Francis; 1988.

Guyton AC. Tratado de Fisiologia Médica. $9^{a}$ ed. Rio de Janeiro: Ed. Guanabara Koogan -Interamericana; 1996. p.76

Habes D, Carison W, Badger D. Muscle fatigue associated with repetitive arm lifts: effects of heigh, weight and reach. Ergonomics 1985; 28 (2): 471-488.

Hemingway A. The Physiological Background of Fatigue. In: Floyd WF, Welford AT, editors. Symposium on Fatigue. London: H. K. Lewis \& Co. Ltd., 1953.

Holding DH. Fatigue In: Hockey R, editor. Stress and Fatigue in Human Performance. Chichester: John Wiley \& Sons, 145-167, 1984.

Hueting JE, Sarphati HR. Measuring Fatigue. J Appl Psychol 1966: 50 (6): 535538.

lida I. Ergonomia: Projeto e Produção. São Paulo: Edgard Blucher; 1992.

Iyer MB, Mitz AR, Winstein C. Sistemas Motores - Motor 1-Centros Inferiores. In: Cohen $\mathrm{H}$, editor. Neurociências para Fisioterapeutas. São Paulo: Ed. Manole; 2001. p.236

Kennedy HG. Fatigue and fatigability. The Lancet 1987; May 16: 1145. 
Kahn JF, Monod H. Fatigue induced by static work. Ergonomics 1989; 32 (7): 839846.

Kjellberg A, Sköldström B. Fatigue effects of noise on aeroplane mechanics. Work \& Stress 1996; 10 (1): 62-71.

Kristal-Boneh E, Froom P, Harari G, Ribak J. Fatigue among israeli industrial employees. J Occup Environ Med 1996; 38 (11): 1145-49.

Kolb B, Wishaw IQ. Neurociência do Comportamento. São Paulo: Ed. Manole; 2002. p. 476

Lazarus RS, Folkman S. Stress, Appraisal, and Coping.New York:Springer Publishing Company; 1984a. The coping process: an alternative to traditional formulations; $p .141-178$.

Lazarus RS, Folkman S. Stress, Appraisal, and Coping.New York:Springer Publishing Company; 1984b. The concept of coping; p.117-139.

Le Guillant, Roelens, Begoin, Béquart, Hansen, Lebreton. Traduzido por Monetti D, Ferreira LL. A neurose das telefonistas. Rev Bras Saúde Ocup 1984; 47 (12): 4852.

Lee J. Roots of fatigue. New Scientist Inside Science 1994; 21 May: 1-4.

Lee P. Recent Developments in Chronic Fatigue Syndrome (Foreword). Excerpta Medica, Inc, p: 1S, 1998.

Lefèvre F, Lefévre AMC, Teixeira JJV. O Discurso do Sujeito Coletivo - uma abordagem metodológica em pesquisa qualitativa. Caxias do Sul: EDUSC; 2000.

Lehman AM, Lehman DR, Hemphill KJ, Mandel DR, Cooper L. Illness Experience, Depression and Anxiety in Chronic Fatigue Syndrome. J Psychosom Res 2002; 52: 461-465.

Lent R. Cem Bilhões de Neurônios - conceitos fundamentais de neurociência. São Paulo: Ed. Atheneu; 2001. p. 529, p. 658.

Lewis $\mathrm{G}$, Wessely $\mathrm{S}$. The epidemiology of fatigue: more questions than answers. J Epidemiol Community Health 1992; 46: 92-97.

Llory M. Acidentes Industriais: O Custo do Silêncio. Rio de Janeiro: Multimais Editorial Produções Ltda; 1999. p. 85

Loriol M. "Mauvaise fatigue"et controle de soi: une approache sociohistorique. Pistes [periódico online] 2002; 4(1). Disponivel em http://pettnt/4n1/articles/v4n1a5.htr $>$ [2002junho]

McAtamney L, Corlett EN. Reducing the Risks of Work Related Upper Limb Disorders - a Guide and Methods. The Institute for Occupational Ergonomics, University of Nothingham, 1992. 
MacFarland RA. Section I: Fatigue in Industry - Understanding Fatigue in Modern Life. Ergonomics 1971; 14 (1): 1-10.

Maciel RH. Ergonomia e lesões por esforços repetitivos. In: W Codo, Almeida MC, LER -Lesões por Esforços Repetitivos. São Paulo: Ed Vozes; 1995. p. 163-172

Maitra SR, Koyal NS. Experimental Studies of Muscular Fatigue of Bengales with Increasing Work Loads under Different Environmental Conditions. Ergonomics 1971; 14(1): 71-84.

Malmqvist R, Ekholm I, Lindström L, Petersèn I, Örtengren R, Bjurö T, Heberts P, Kadefors R. Measurement of localized muscle fatigue in building work. Ergonomics 1981; 24(9): 695-709.

Marx K. O Capital: o processo de produção do capital. Trad. de Sant'Anna R. São Paulo: Ed.bertrand do Brasil; 1987. v.1. p.202.

Matsuda S, Luong NA, Hoai NV, Thung DH, Trinh LV, Cong NT, Dat PH, Tri DD. A study of complaints of fatigue by workers employed in vietnamese factories with newly imported technology. Ind Health 1997; 35: 16-28.

Mayo E. Problemas Humanos de uma Civilización Industrial. Buenos Aires: Ed. Galatea Nueva Visión S. R. L: 1959. p. 21-41

Merton P A. Voluntary Strength and Fatigue. J Physchol 1954; 123 (3): 553-564.

Metzner RJ. Trabalhadores em uma indústria têxtil: um estudo sobre fadiga e capacidade para o trabalho em turnos fixos de 12 horas em semana reduzida.

São Paulo; 2000. [Dissertação de Mestrado - Faculdade de Saúde Pública da USP].

Metzner RJ, Fischer FM. Fadiga e capacidade para o trabalho em turnos fixos de doze horas. Rev Saúde Pública 2001; 35 (6): 548-53.

Mikhail A. Stress: a phychophysiological conception.J Human Stress 1981, 7 (1): 915.

Milosevic S. Driver's fatigue studies. Ergonomics 1997; 40 (3): $381-389$.

Minayo MCS. O Desafio do Conhecimento: Pesquisa Qualitativa em Saúde.

São Paulo: Ed. Hucitec; 1992.

Ministério da Saúde do Brasil. Representação no Brasil da OPAS/OMS. Doenças Relacionadas ao Trabalho: manual de procedimentos para os serviços de saúde. Organizado por Dias EC.Brasília: Editora MS, 2001. p.184-186

Mosso A. La fatigue Intellectuelle et Physique. Paris: Félix Alcan Ėditeur; 1896. p.

Muscio B. Is a Fatigue Test Possible? Br j Psychol 1921a; 12: 31-46.

Muscio B. Feeling-Tone in Industry. Br j Psychol 1921b; 12: 150-162.

Nardi HC, Tittoni J, Barnardes JS. Subjetividade e trabalho. In: Cattani A D, (org.). Trabalho e Tecnologia (2 Ed.). Petropólis: Editora Vozes; 1999. p. 240-246. 
Organização Mundial de Saúde, Centro Colaborador da OMS para a Classificação de Doenças em Português, Faculdade de Saúde Pública da Universidade de São Paulo/Organização Pan-Americana de Saúde. Classificação Estatística Internacional de Doenças e de Problemas Relacionados a Saúde: Décima Revisão [disquete]. Implementação para disseminação eletrônica efetuada pela FNS - DATASUS - Departamento de Informática do SUS; 1993.

Organização Mundial de Saúde, Centro Colaborador da OMS para a Classificação de Doenças em Português, Universidade de São Paulo. Classificação Estatística Internacional de Doenças e Problemas Relacionados a Saúde: Décima Revisão. São Paulo: Edusp; 1994. v.2. p.22.

Örtengren R, Anderson G, Broman H, Magnusson R, Petersén I. Vocational Eletromyography: Studies of Localized Muscle Fatigue at the Assembly Line. Ergonomics 1975; 18(2): 157-174.

Peres MFP, Zukerman, Young WB, Sliberstein SD. Fatigue in Chronic migraine patitnts. Cephalalgia 2002; 22:720-724.

Putz-Anderson V, Galinsky T L. Psychophysically Determined Work Durations for Limiting Shoulder Girdle Fatigue from Elevated Manual Work. Int J Ind Ergon 1993; 11: 19-28.

Queiróz MFF. Estudo Comparativo de Dois Postos de Trabalho na Indústria Automática e na Industria Manual do Vidro. São Paulo; 1998. [Dissertação de Mestrado - Faculdade de Saúde Pública da USP].

Queiroz MFF, Maciel RH. Condiçōes de Trabalho e Automação: O Caso do Soprador da Indústria Vidreira. Rev Saúde Pública 2001; 35 (1): 1-9.

Raggatt PTF, Morrissey SA. A Field Study of Stress and Fatigue in Long Distance Bus Drives. Behav Med 1997; 23:122-128.

Ream E, Richardson A. Fatigue: A Concept Analysis. Int J Nurs Stud 1996; 33 (5): 519 529.

Ryan TA. Muscular potencials as indicators of effort in visual tasks. In: Floyd WF, Welford AT, editors. Symposium on Fatigue. London: H. K. Lewis \& Co. Ltd., 1953.

Schwab RS. Motivation in Measurements of Fatigue. In: Floyd WF, Welford AT, editors. Symposium on Fatigue. London: H. K. Lewis \& Co. Ltd., 1953.

Selye H. History and Present Status of Stress' Concept. In: Breznitz S, Goldberger L. Handbook of stress: theoretical and clinical aspects. New York: The Free Press; 1982. p. 7-17

Simioni AMC, Lefévre F, Pereira IMTB. Metodologia Qualitativa nas Pesquisas em Saúde Coletiva: Considerações Teóricas e Instrumentais. Série Monográfica № 2-Eixo promoção de Saúde, Centro de estudos e Pesquisas de Direito Sanitário-Universidade de São Paulo-Faculdade de Saúde PúblicaDepartamento de Práticas de Saúde Pública, 1996. 
Smith MA. Contibution to the Study of Fatigue. Br j Psychol 1915-1917; 8: $327-$ 350.

Short K, McCabe M, Tooley G. Cognitive Functioning in Chronic Fatigue Syndrome and the Role of Depression, Anxiety and Fatigue. J Psychosom Res 2002; 52 : 475-483.

Souza MFM, Messing K, Menezes PR, Cho HJ. Chronic Fatigue Among Bank Workers in Brazil. Occup Med 2002; 52(4):187-194.

Tsaneva N, Markov S. A Model of Fatigue. Ergonomics 1971; 14 (1): 11-16.

Valencia F. Local muscle fatigue: A precursor to RSI? Med J Aust 1986; 145(6) : 3327-329.

Yoshitake $\mathrm{H}$. Relations between the Symptoms and the Feeling of Fatigue.

Ergonomics 1971; 14(1): 175-186.

Welch RB, Longley EO, Lomaev $\mathrm{O}$. The measurement of fatigue in hot working conditions. Ergonomics 1971; 14(1): 85-90.

Welford AT. The Psychologist's Problem in Measuring Fatigue. In: Floyd WF, Welford AT, editors. Symposium on Fatigue. London: H. K. Lewis \& Co. Ltd., 1953.

Wessely S, Matthew H, Sharpe M. Chronic Fatigue and its Syndromes. Oxford: Oxford Univerity Press, 1998.

Wisner A. Por Dentro do Trabalho - ergonomia técnica. São Paulo: Ed. FTD: Oboré;1987. p. 11e 39.

Wisner A. Fatigue and human realiability revisited in the light of ergonomics and work psychopatology. Ergonomics 1989; 7: 891- 898.

Wisner, A. A Inteligência no Trabalho. São Paulo, Ed. Unesp-FUNDACENTRO, 1994. 
ANEXO I 
I. NOME DO ENTREVISTADO :

DOCUMENTO DE IDENTIDADE $\mathrm{N}^{0}$ :

II. TITULO DO PROJETO DE PESQUISA:

PESQUISA SOBRE O CONCEITO DE FADIGA: ESTUDO DE CASO DOS TRABALHADORES

EM UMA INDÚSTRIA GRÁFICA

III. ORIENTADORA: REGINA HELOÍSA MACIEL PROFA DOUTORA DA UNIVERSIDADE ESTADUAL DO CEARÁ, CREDENCIADA PELA FACULDADE DE SAÚDE PÚBLICA DA USP

IV. COORDENADORA E PESQUISADORA: MARIA DE FÁTIMA FERREIRA QUEIRÓZ DOUTORANDA DA FACULDADE DE SAÚDE PÚBLICA -USP

\section{ESCLARECIMENTOS DO PESQUISADOR AO ENTREVISTADO:}

1. JUSTIFICATIVA E OBJETIVOS DA PESQUISA:

A fadiga é acometimento comum entre a população, mas seu conceito é de dificil definição, portanto esta pesquisa pretende compreender como a fadiga é entendida pelos trabalhadores que podem vir a sofrer com este problema

2.GARANTIMOS QUE VOCÊ TERÁ ACESSO EM QUALQUER TEMPO, ÀS INFORMAÇÕES SOBRE PROCEDIMENTOS, RISCOS E BENEFICIOS RELACIONADOS À PESQUISA, INCLUSIVE PARA ESCLARECER EVENTUAIS DÚVIDAS.

3. ESCLARECEMOS QUE O ENTREVISTADO TEM A LIBERDADE DE RETIRAR SEU CONSENTIMENTO A QUALQUER MOMENTO E DE DEIXAR DE PARTICIPAR DO ESTUDO, SEM QUE ISTO TRAGA PREJUÍZO À SUA PESSOA.

4. OS PESQUISADORES FIRMAM O COMPROMISSO SOBRE A SEGURANÇA DE QUE NÃO SE IDENTIFICARÁ O INDIVIDUO ENTREVISTADO E QUE SE MANTERÁ O CARÁTER CONFIDENCIAL dA INFORMAÇ̃̃o RELACIONADA COM A SUA PRIVACIDADE.

VI - CONSENTIMENTO PÓS-ESCLARECIDO

DECLARO QUE, APÓS TER SIDO CONVENIENTE ESCLARECIDO PELO PESQUISADOR. CONFORME REGISTRO NOS ITENS 1 A 4, DO INCISO V, CONSINTO EM PARTICIPAR, NA QUALIDADE DE ENTREVISTADO, DO PROJETO DE PESQUISA REFERIDO NO INCISO II.

São Paulo,

assinatura do pesquisador que obteve o consentimento de

de 2001 
ANEXO II 


\section{Escala de Fadiga de Chalder ${ }^{1}$}

\section{Sintomas fisicos}

1-Você vem se sentindo cansado?

1 Menos que o habitual

20 mesmo que o habitual

3 Mais que o habitual

4 Muito mais que o habitual

2- Você sente necessidade de mais descanso (repouso)?

1 Menos que o habitual

20 mesmo que o habitual

3 Mais que o habitual

4 Muito mais que o habitual

3- Você tem se sentido com sono ou sonolento?

1 Menos que o habitual

20 mesmo que o habitual

3 Mais que o habitual

4 Muito mais que o habitual

4-Você tem problemas para iniciar seus afazeres?

1 Menos que o habitual

20 mesmo que o habitual

3 Mais que o habitual

4 Muito mais que o habitual

5-Você tem sentido falta de energia?

1 Menos que o habitual

20 mesmo que o habitual

3 Mais que o habitual

4 Muito mais que o habitual

6-Você sente fraqueza em seus músculos?

1 Menos que o habitual

20 mesmo que o habitual

3 Mais que o habitual

4 Muito mais que o habitual

${ }^{1}$ Chalder et al Psychosom Res, 37: 147-153, 1993. 
7-Você tem se sentido fraco?

1 Menos que o habitual

20 mesmo que o habitual

3 Mais que o habitual

4 Muito mais que o habitual

\section{Sintomas Mentais}

8-Você tem dificuldade de concentração?

1 Menos que o habitual

20 mesmo que o habitual

3 Mais que o habitual

4 Muito mais que o habitual

9-Você sente a língua enrolar ou a língua pesada quando você fala?

1 Menos que o habitual

20 mesmo que o habitual

3 Mais que o habitual

4 Muito mais que o habitual

10- Você sente mais dificuldades para encontrar a palavra certa?

1 Menos que o habitual

20 mesmo que o habitual

3 Mais que o habitual

4 Muito mais que o habitual

11-Você sente dificuldade de memorização?

1 Menos que o habitual

20 mesmo que o habitual

3 Mais que o habitual

4 Muito mais que o habitual

Questões sobre dor muscular

12-Seus músculos doem durante o repouso?

1 Menos que o habitual

20 mesmo que o habitual

3 Mais que o habitual

4 Muito mais que o habitual 
13-Seus músculos doem após realizar exercícios?

1 Menos que o habitual

20 mesmo que o habitual

3 Mais que o habitual

4 Muito mais que o habitual

\section{Relacões com o Tempo}

14-Se estiver cansaço neste momento favor indicar há quanto tempo.

1-Menos de uma semana

2-Menos de três meses

3-Entre três e seis meses

4-Mais de seis meses

15- Considerando os últimos 12 meses, qual a porcentagem de tempo em que você sentiu-se cansado (a)?

1- $25 \%$ do tempo

2- $50 \%$ do tempo

3- $75 \%$ do tempo

4- todo o tempo

16- O que faz você pensar que está cansado? Por favor tente dar uma razão. 
ANEXO III 
UNIVERSIDADE DE SÃO PAULO

FACULDADE DE SAÚDE PÚBLICA DEPARTAMENTO DE SAÚDE AMBIENTAL

PESQUISA SOBRE CONDICÕES DE SAÚDE E TRABALHO ENTRE TRABALHADORES EM UMA INDUSTRIA GRÁFICA 
1- No na Pesquisa

2- Nome

3-Sexo [ ] Feminino [ ] Masculino

4- Data de nascimento

5- Idade anos

6- Escolaridade (Assinale o nivel mais alto)

[ ] I grau incompleto

[ ] II grau incompleto

[ ] I grau completo

[ ] II grau completo

7- Estado Civil

[ ] Solteiro [ ] Separado [ ]Casado [ ] Viúvo [ ] Vivendo junto

8-Sua Função é: [ ]operador 1 [ ]operador 2 [ ]operador 3

9- Tempo de trabalho na função ___

10- Tempo de trabalho na empresa I anos

11- Seu horário de trabalho

[ ] 6:00 às 14:00 [ ] 14:00 às 22:00

[ ] 8:00 às 14:00 [ ] 15:00 às 19:00

[ ] 10:00 às 19:00 [ ] 08:00 às 17:00

12- Você vem se sentindo cansado?

[ ] Menos que o habitual

[ ] O mesmo que o habitual

[ ] Mais que o habitual

[ ] Muito mais que o habitual

13- Você sente necessidade de mais descanso (repouso)?

[ ] Menos que o habitual

[ ] O mesmo que o habitual

[ ] Mais que o habitual

[ ] Muito mais que o habitual

14- Você tem se sentido com sono ou sonolento?

[ ] Menos que o habitual

[ ] O mesmo que o habitual

[ ] Mais que o habitual

[ ] Muito mais que o habitual 
15-Você tem problemas para iniciar seus afazeres?

[ ] Menos que o habitual

[ ] O mesmo que o habitual

[ ] Mais que o habitual

[ ] Muito mais que o habitual

16-Você tem sentido falta de energia?

[ ] Menos que o habitual

[ ] O mesmo que o habitual

[ ] Mais que o habitual

[ ] Muito mais que o habitual

17-Você sente fraqueza em seus músculos?

[ ] Menos que o habitual

[ ] O mesmo que o habitual

[ ] Mais que o habitual

[ ] Muito mais que o habitual

18-Você tem se sentido fraco?

[ ] Menos que o habitual

[ ] O mesmo que o habitual

[ ] Mais que o habitual

[ ] Muito mais que o habitual

19-Você tem dificuldade de concentração?

[ ] Menos que o habitual

[ ] O mesmo que o habitual

[ ] Mais que o habitual

[ ] Muito mais que o habitual

20-Você sente a língua enrolar ou a língua pesada quando você fala?

[ ] Menos que o habitual

[ ] O mesmo que o habitual

[ ] Mais que o habitual

[ ] Muito mais que o habitual

21- Você sente dificuldades para encontrar a palavra certa?

[ ] Menos que o habitual

[ ] O mesmo que o habitual

[ ] Mais que o habitual

[ ] Muito mais que o habitual

22-Você sente dificuldade de memorização?

[ ] Menos que o habitual

[ ] O mesmo que o habitual

[ ] Mais que o habitual

[ ] Muito mais que o habitual 
23-Seus músculos doem durante o repouso?

[ ] Menos que o habitual

[ ] O mesmo que o habitual

[ ] Mais que o habitual

[ ] Muito mais que o habitual

24-Seus músculos doem após realizar exercícios?

[ ] Menos que o habitual

[ ] O mesmo que o habitual

[ ] Mais que o habitual

[ ] Muito mais que o habitual

25-Se estiver cansaço neste momento favor indicar há quanto tempo.

[ ] Menos de uma semana

[ ] Menos de três meses

[ ] Entre três e seis meses

[ ] Mais de seis meses

26- Considerando os últimos 12 meses, qual a porcentagem de tempo em que você sentiu-se cansado (a)?

[ ] $25 \%$ do tempo

[ ] $50 \%$ do tempo

[ ] $75 \%$ do tempo

[ ] todo o tempo

27- O que faz você pensar que está cansado? Por favor tente dar uma razão. 


\section{ANEXO IV}

Entrevistados com Fadiga segundo a Escala de Fadiga de Chalder 


\begin{tabular}{|c|c|c|}
\hline 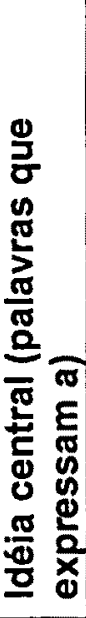 & 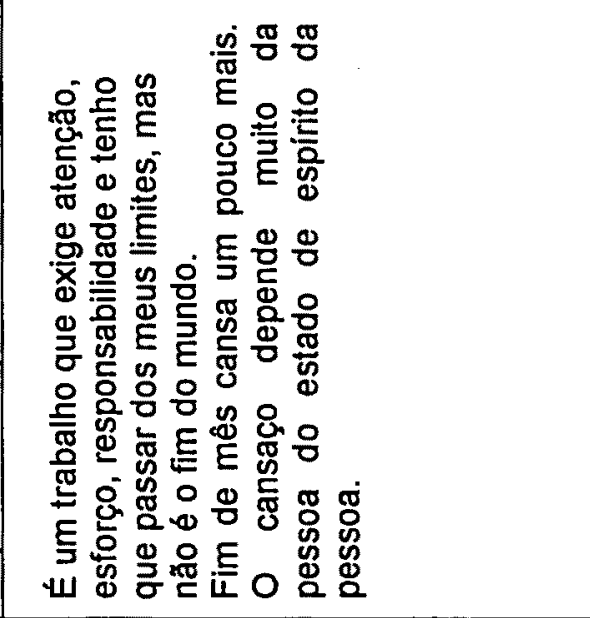 & 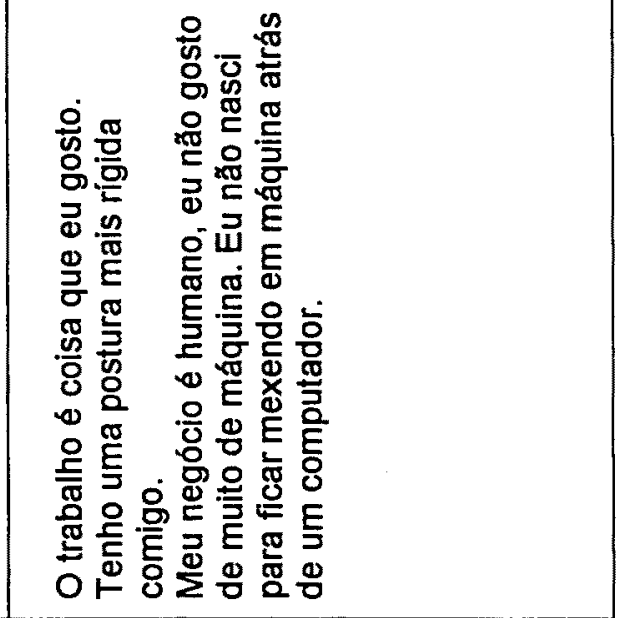 \\
\hline 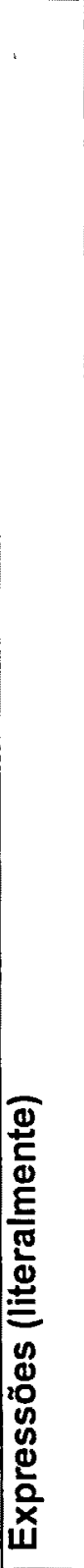 & 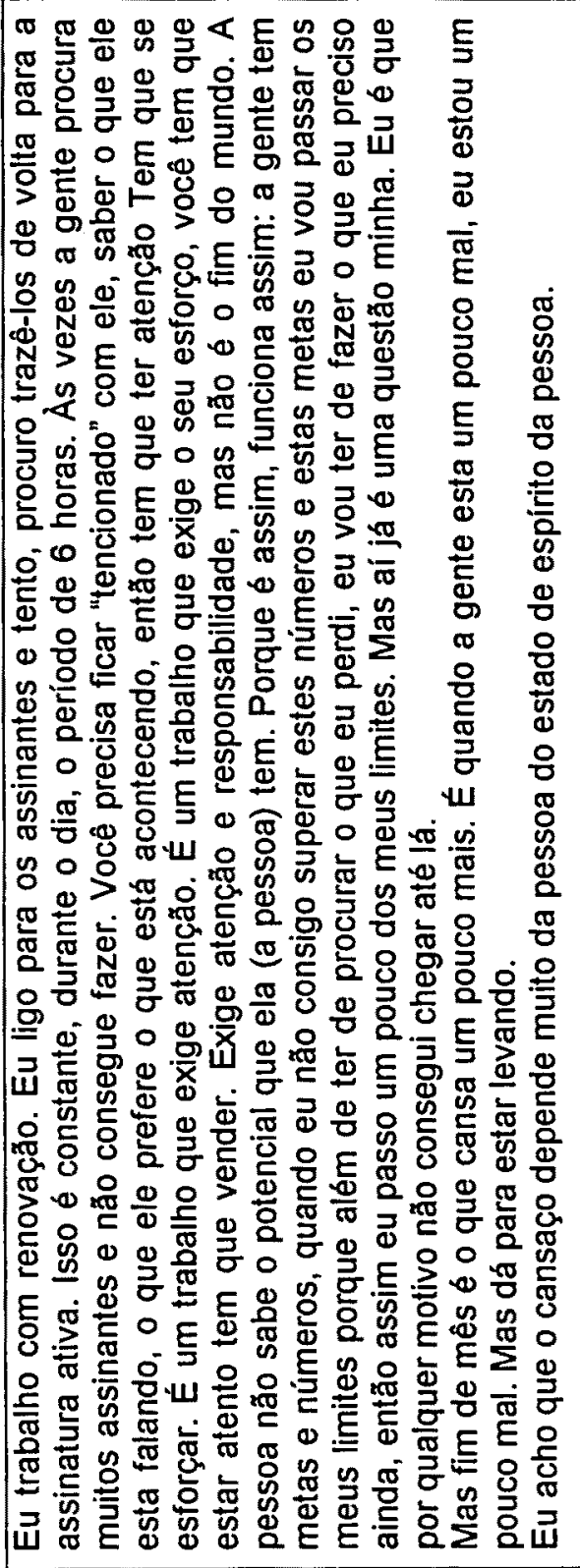 & 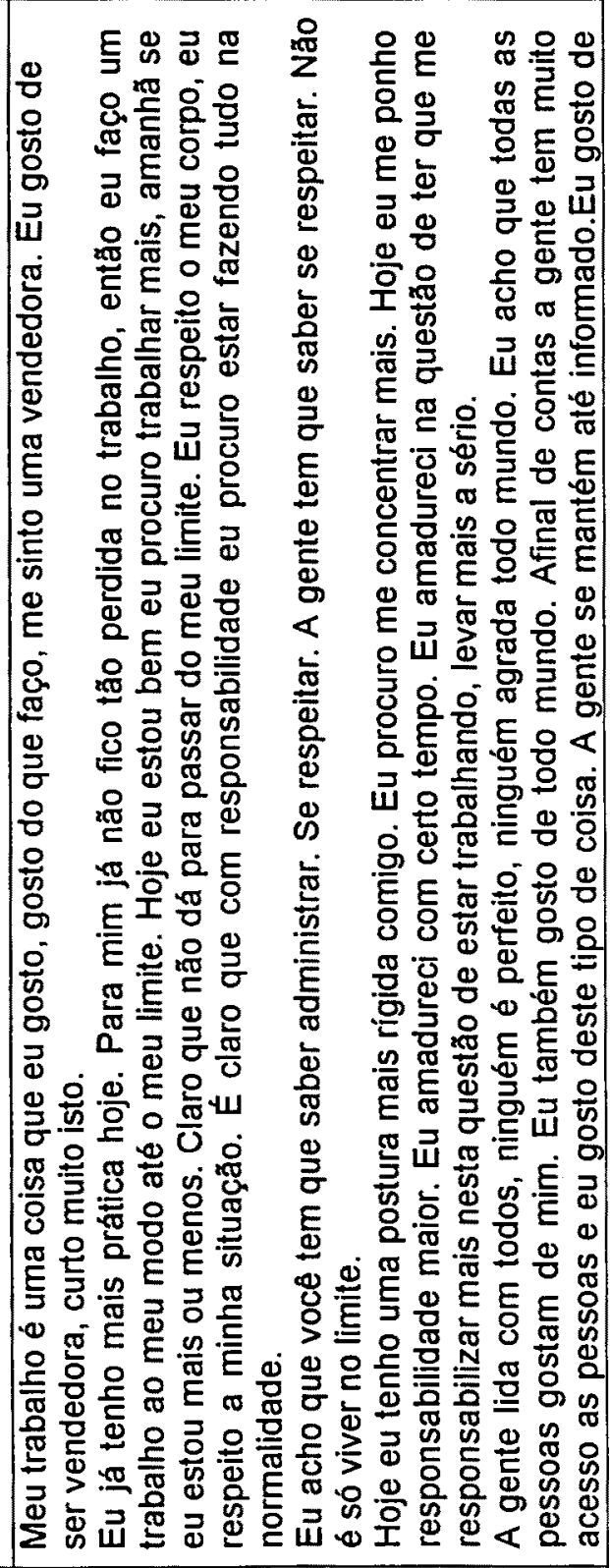 \\
\hline 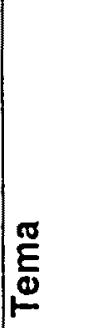 & 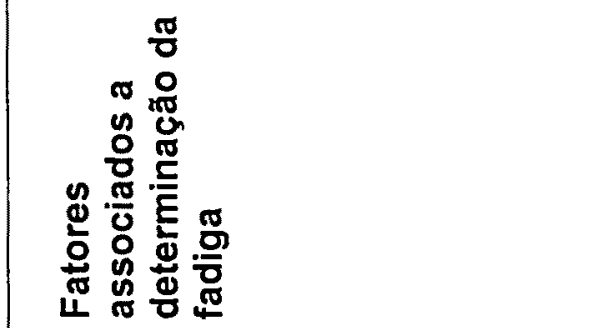 & 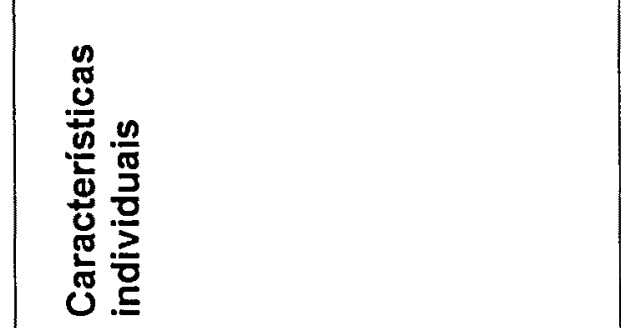 \\
\hline
\end{tabular}




\begin{tabular}{|c|c|c|c|c|}
\hline & 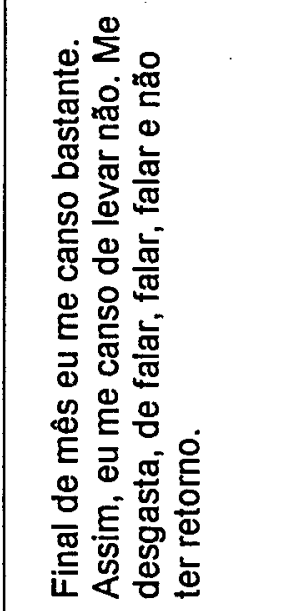 & 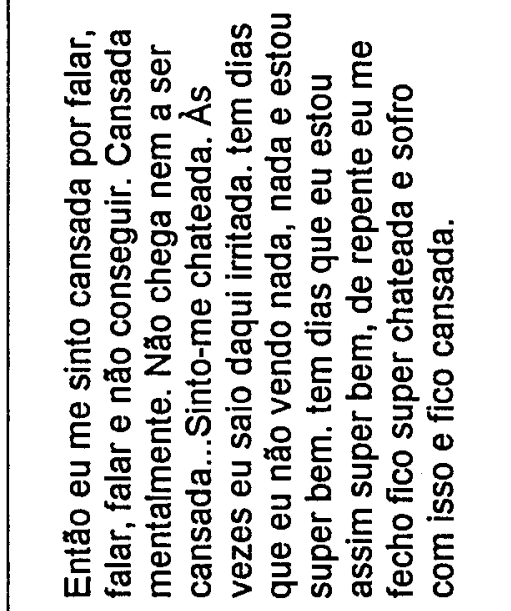 & & \\
\hline 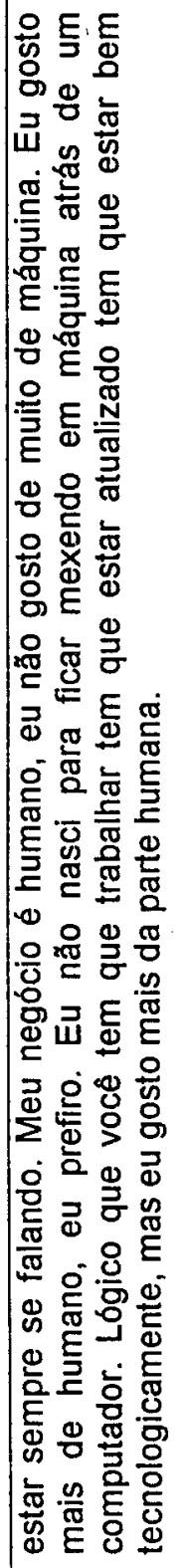 & 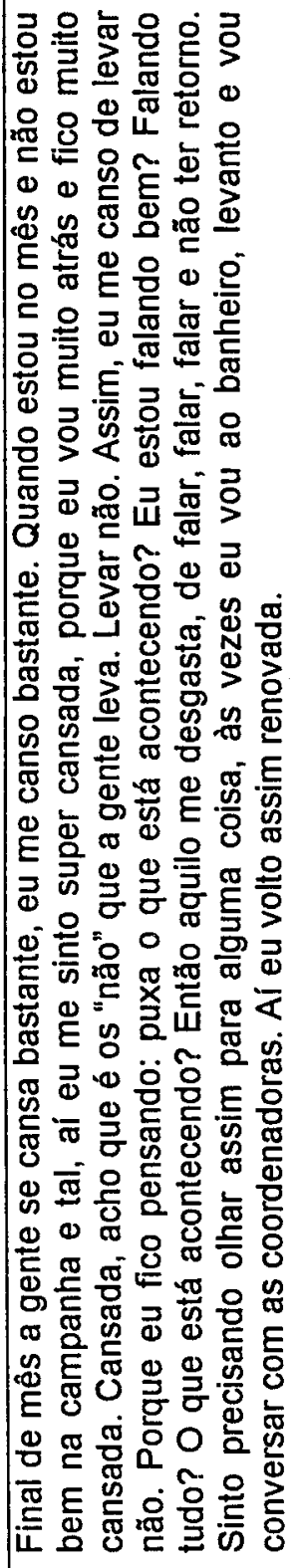 & 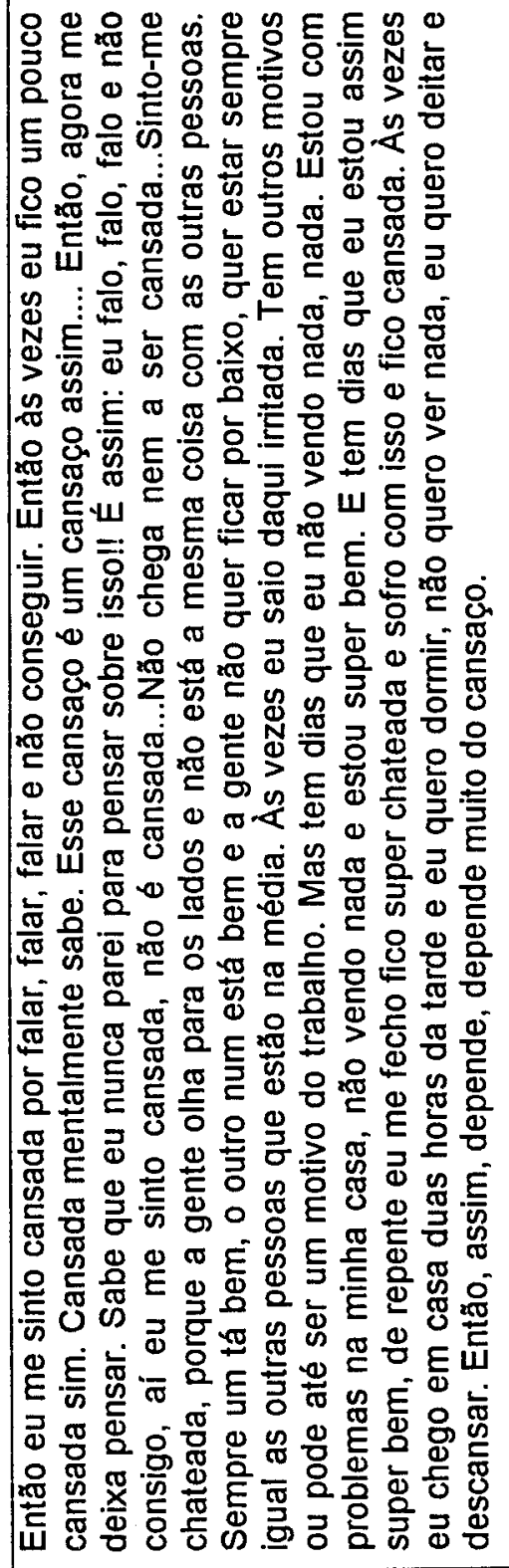 & & \\
\hline & 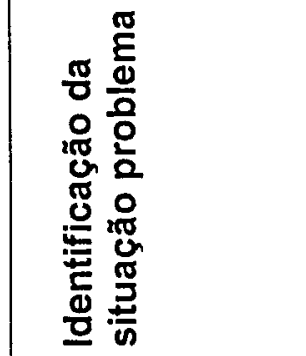 & 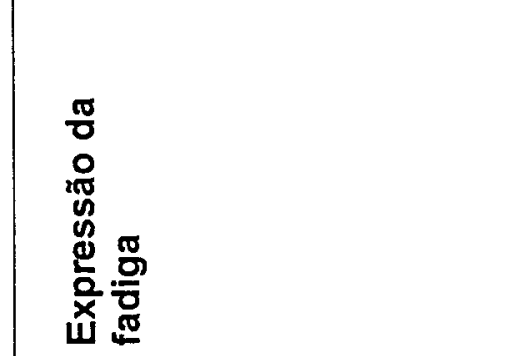 & 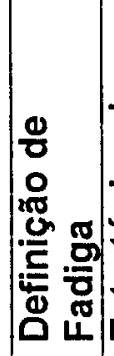 & 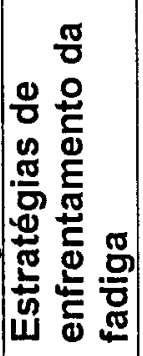 \\
\hline
\end{tabular}




\begin{tabular}{|c|c|c|c|c|}
\hline 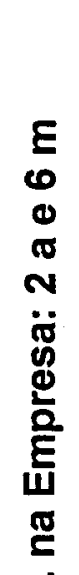 & 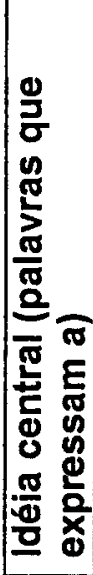 & 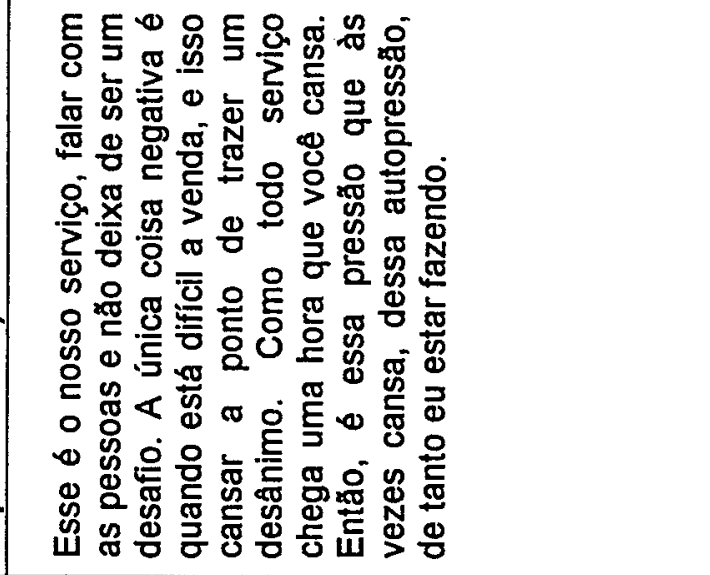 & 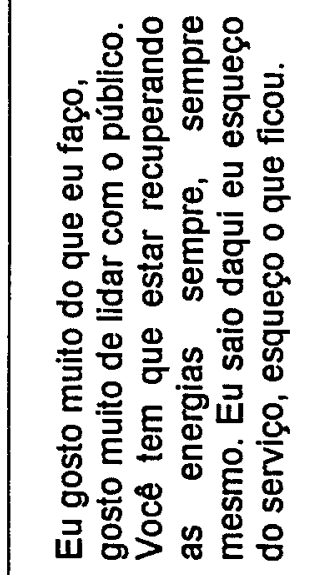 & 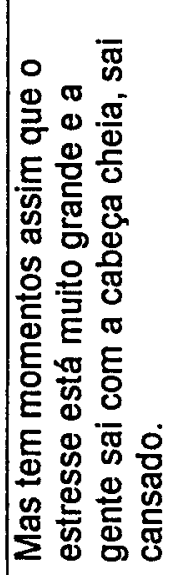 \\
\hline 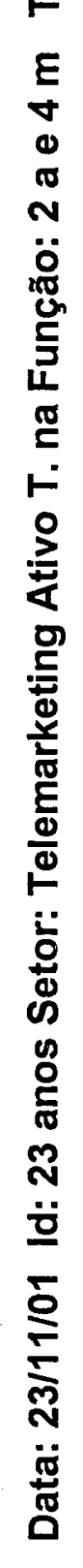 & 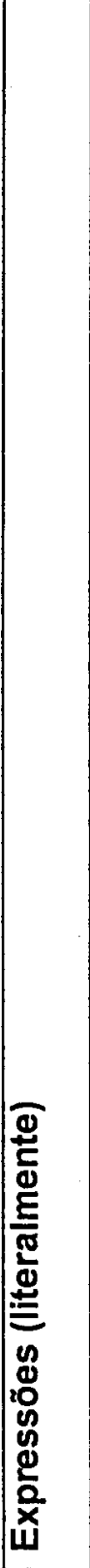 & 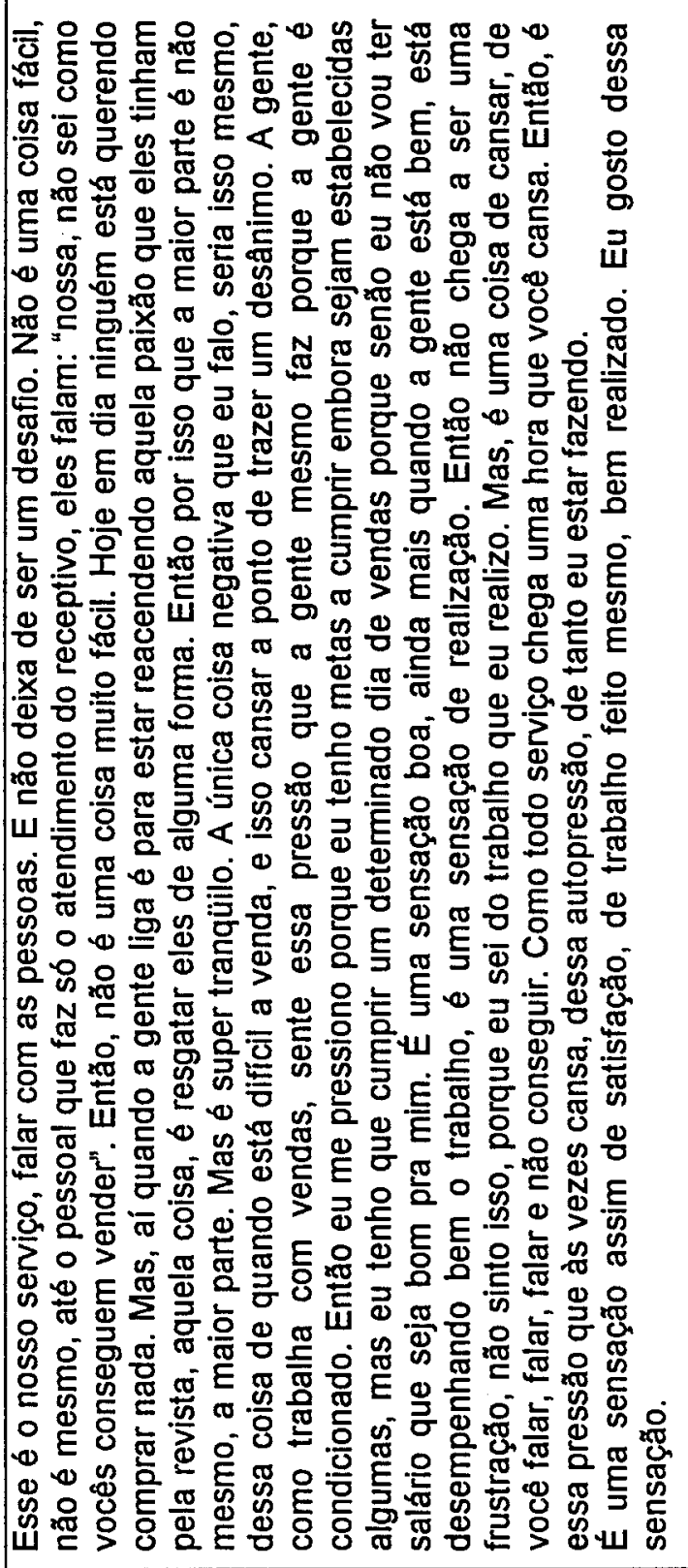 & 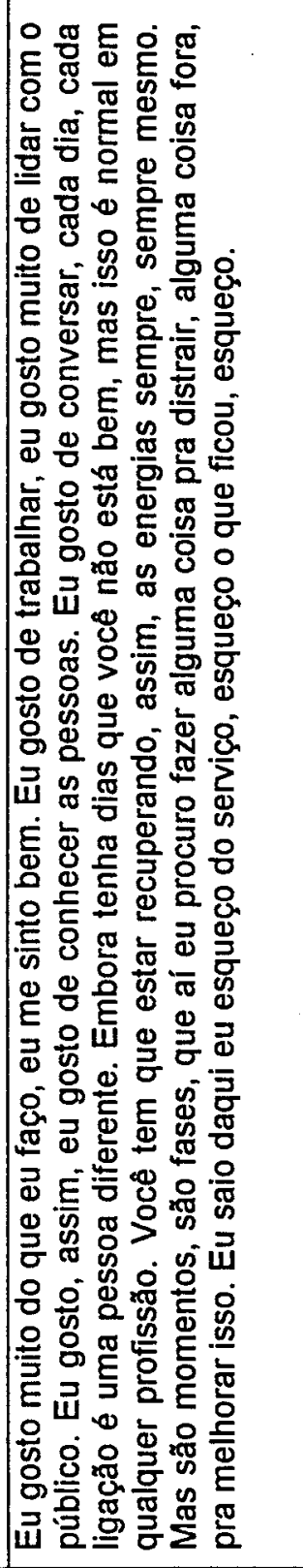 & 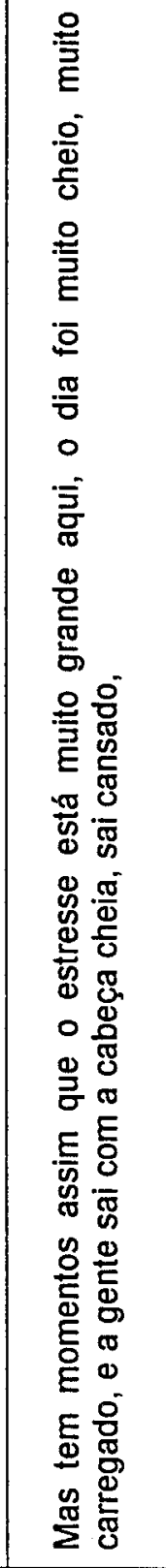 \\
\hline 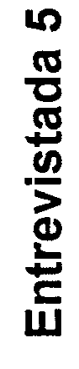 & 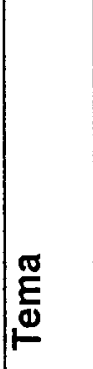 & 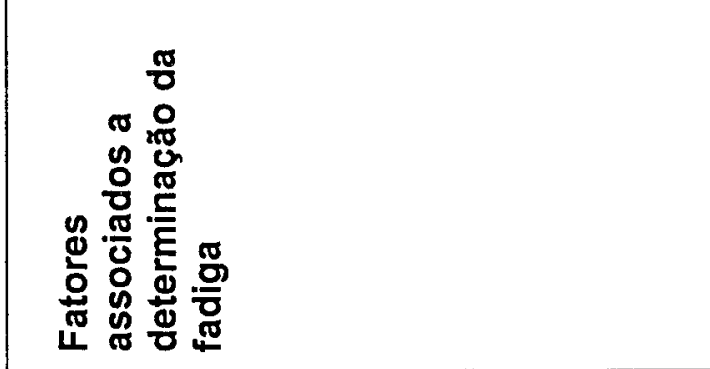 & 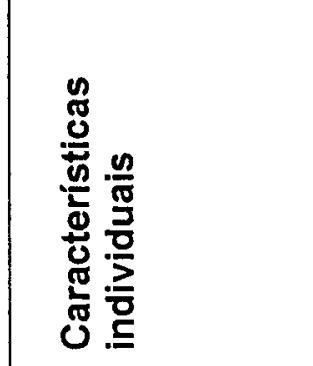 & 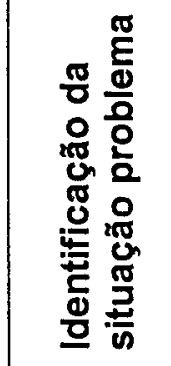 \\
\hline
\end{tabular}




\begin{tabular}{|c|c|c|}
\hline 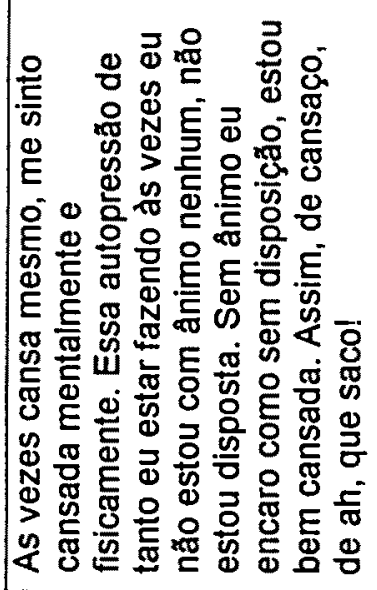 & & 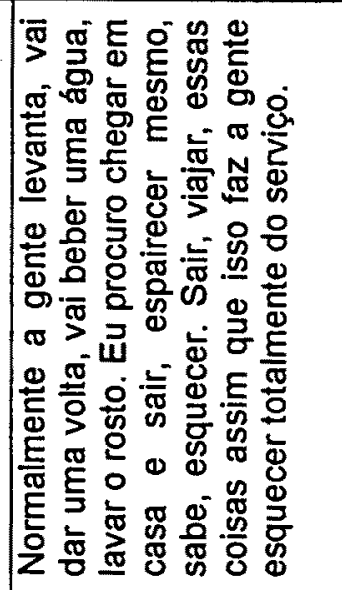 \\
\hline 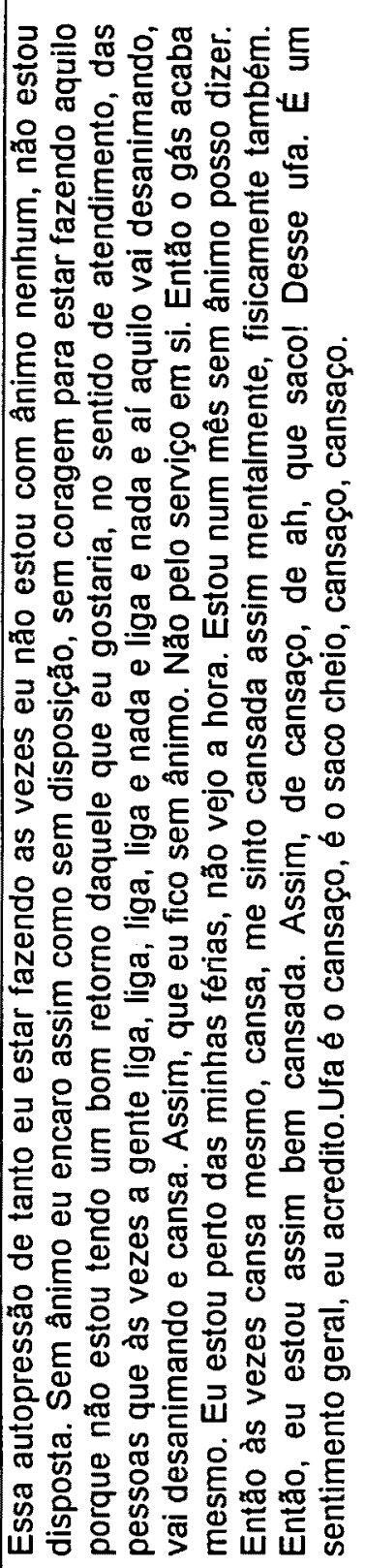 & & 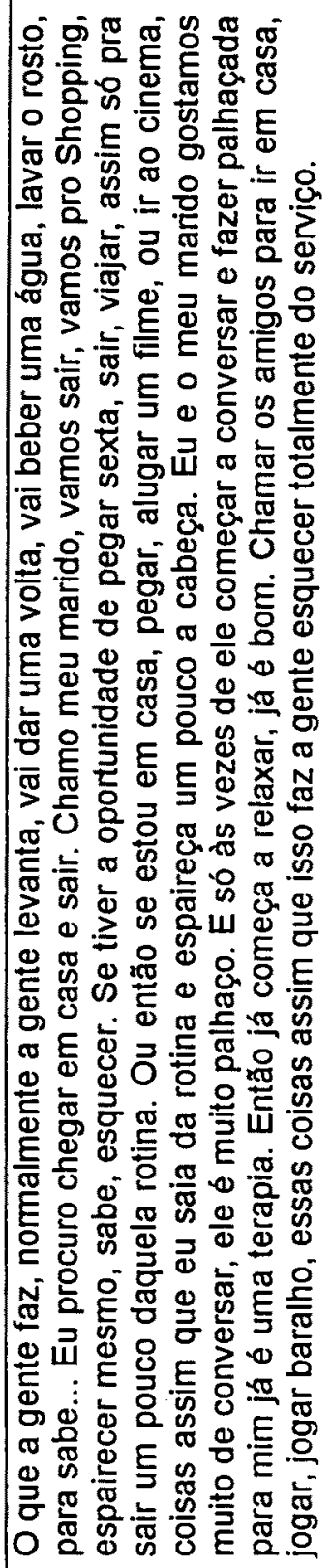 \\
\hline 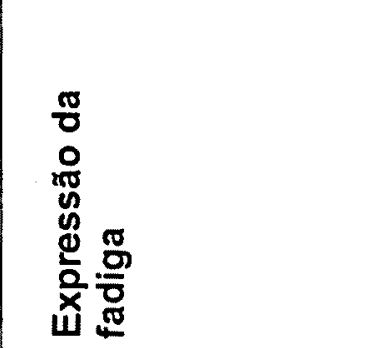 & 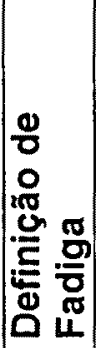 & 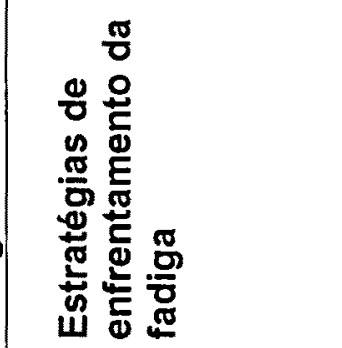 \\
\hline
\end{tabular}




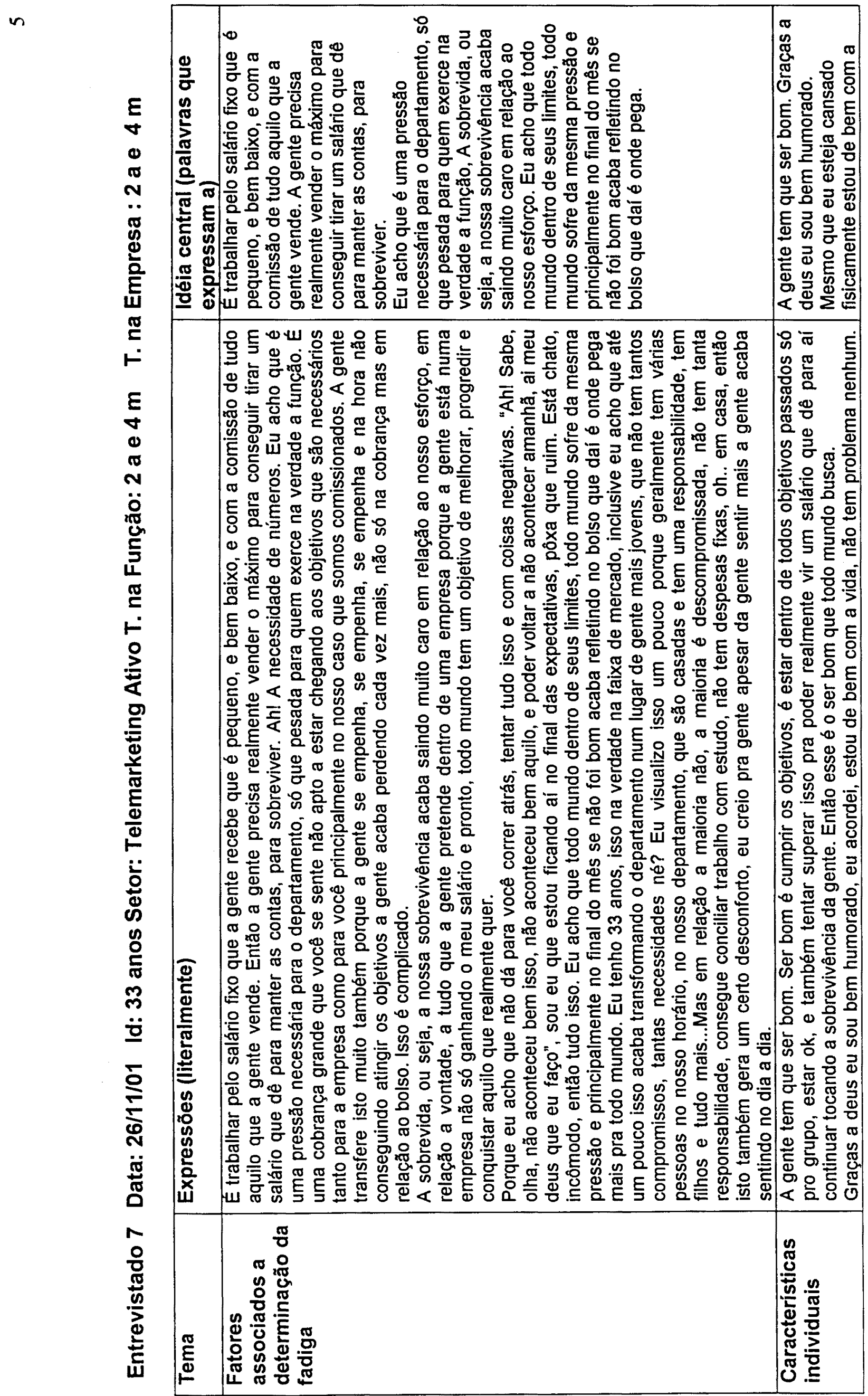




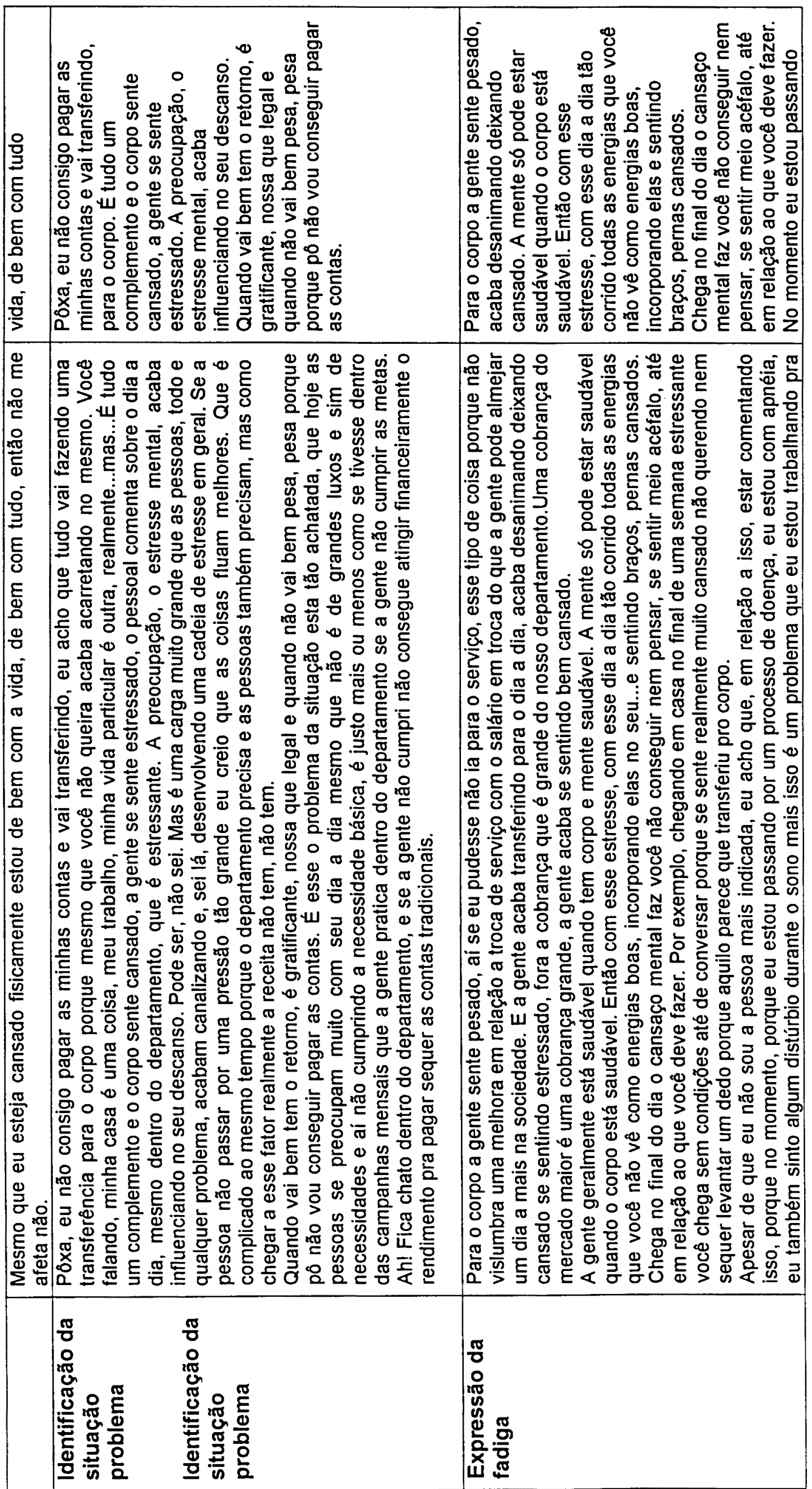




\begin{tabular}{|c|c|c|}
\hline 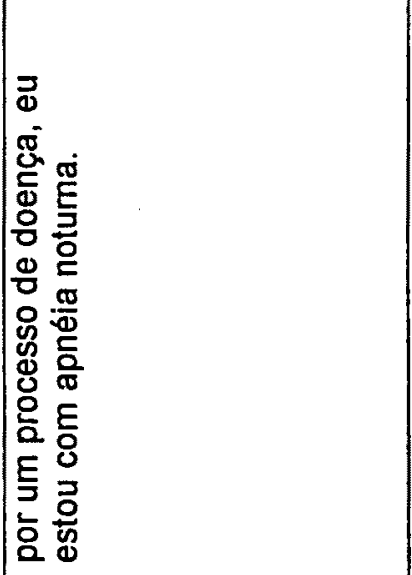 & 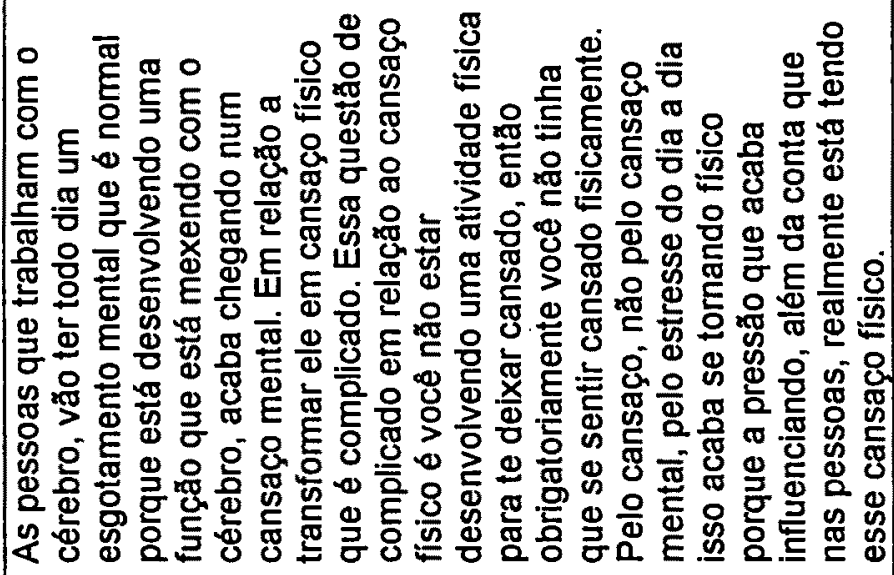 & \\
\hline 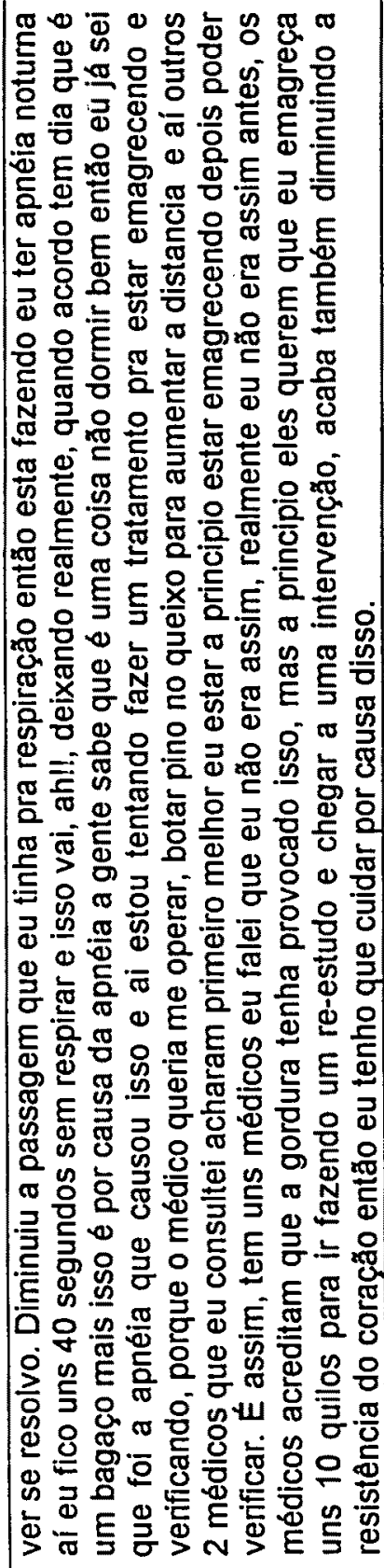 & 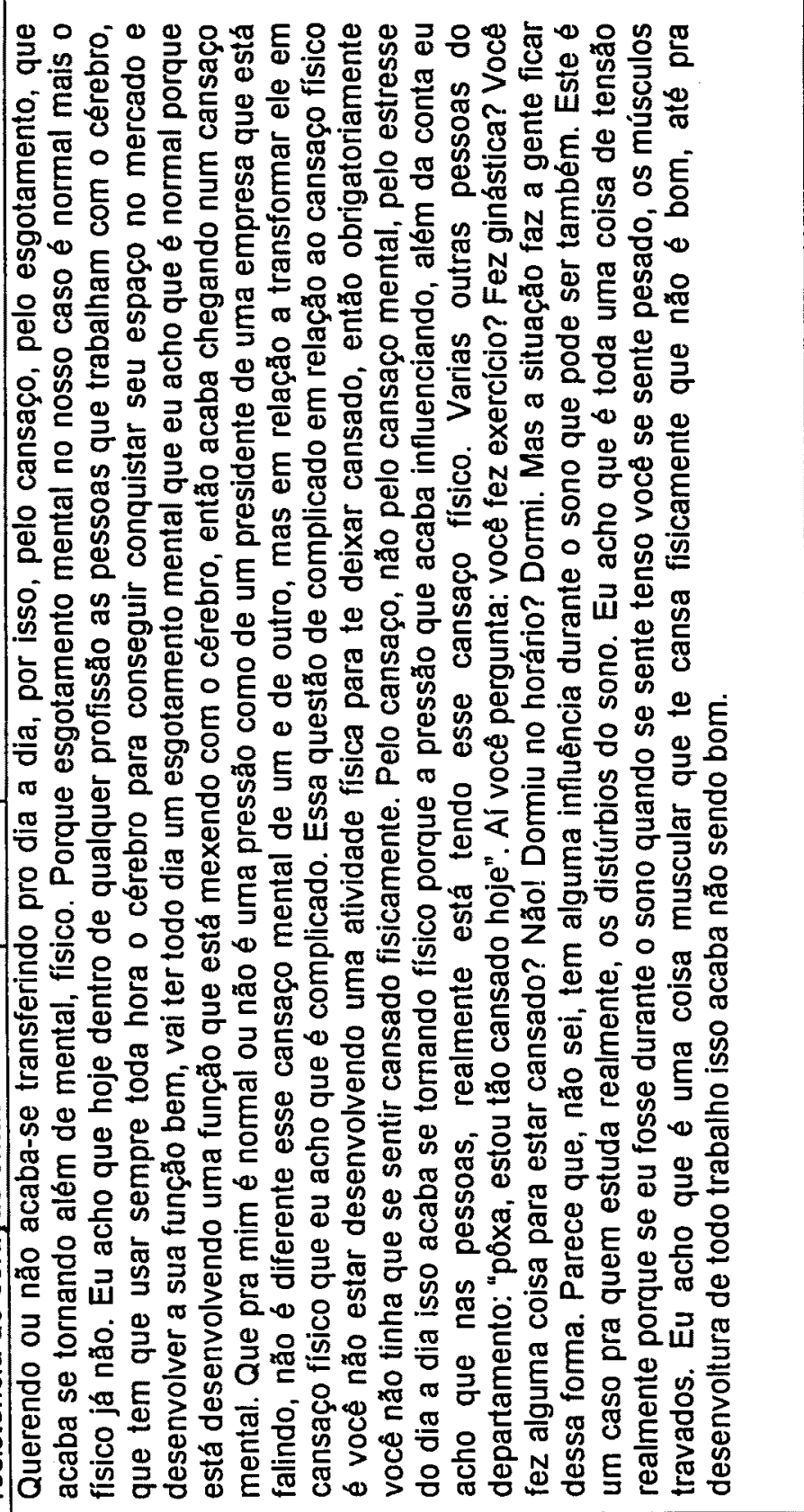 & \\
\hline & 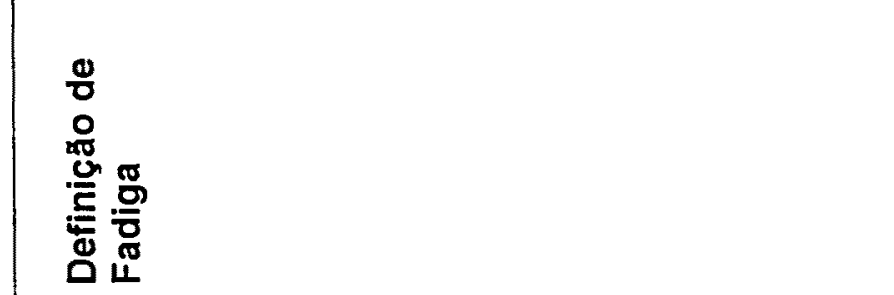 & 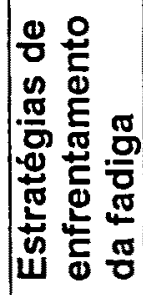 \\
\hline
\end{tabular}




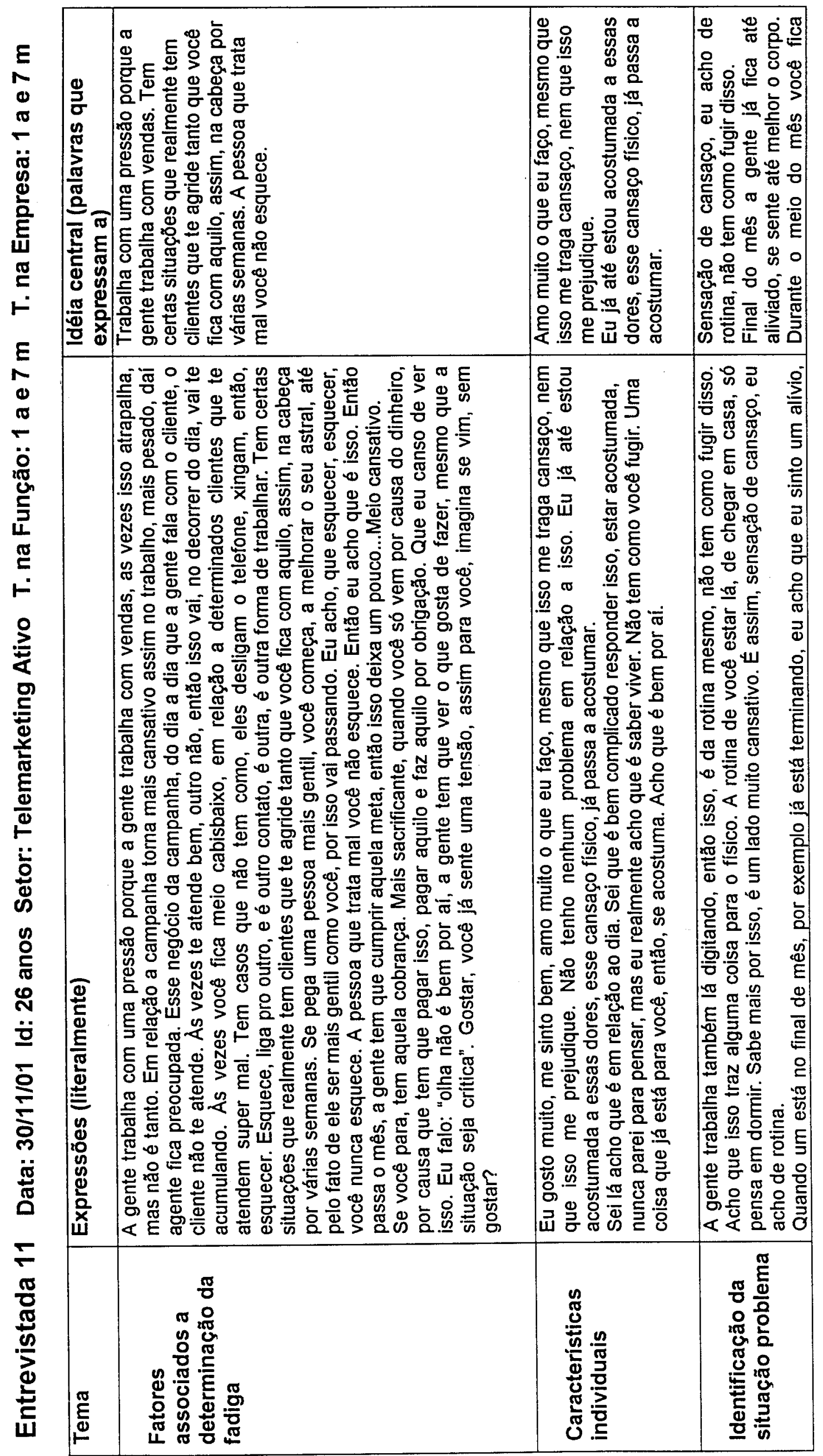


$a$

\begin{tabular}{|c|c|c|c|}
\hline 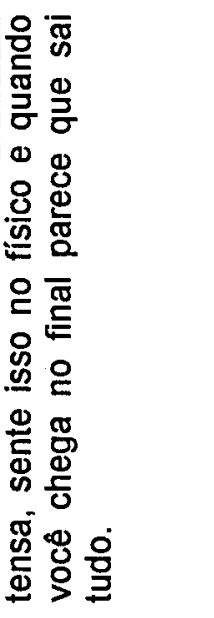 & 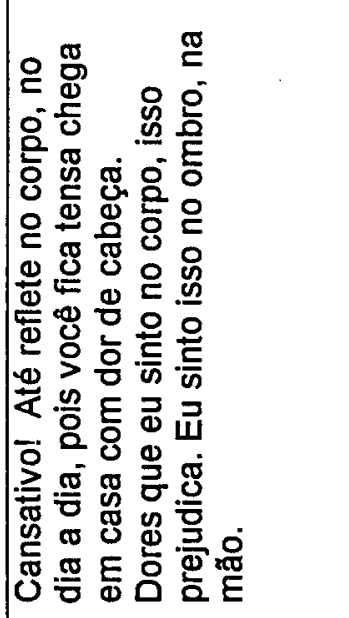 & & 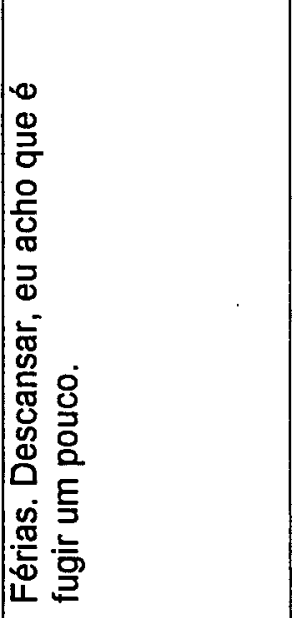 \\
\hline 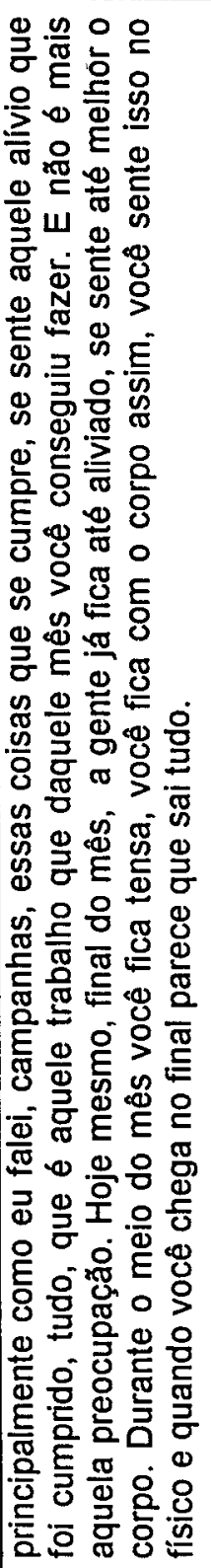 & 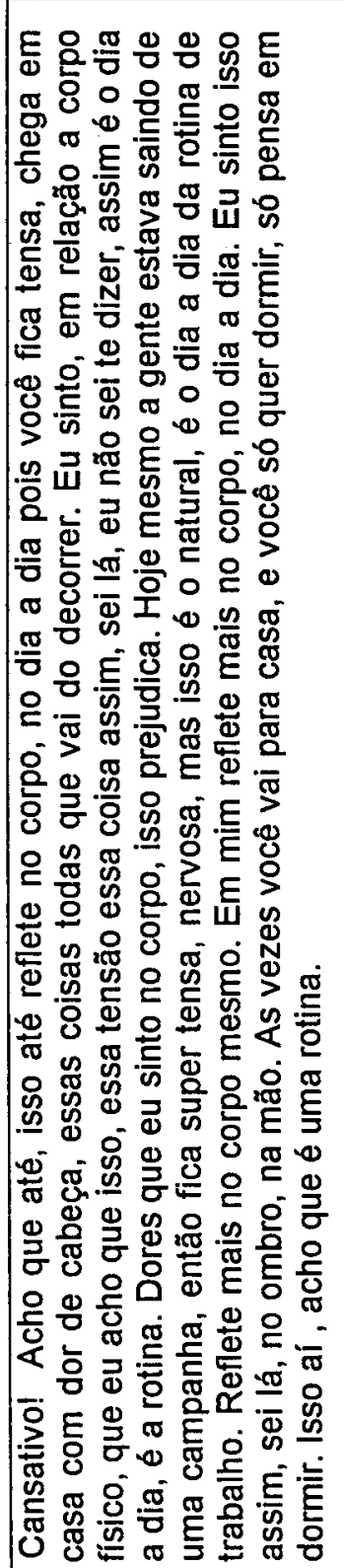 & & 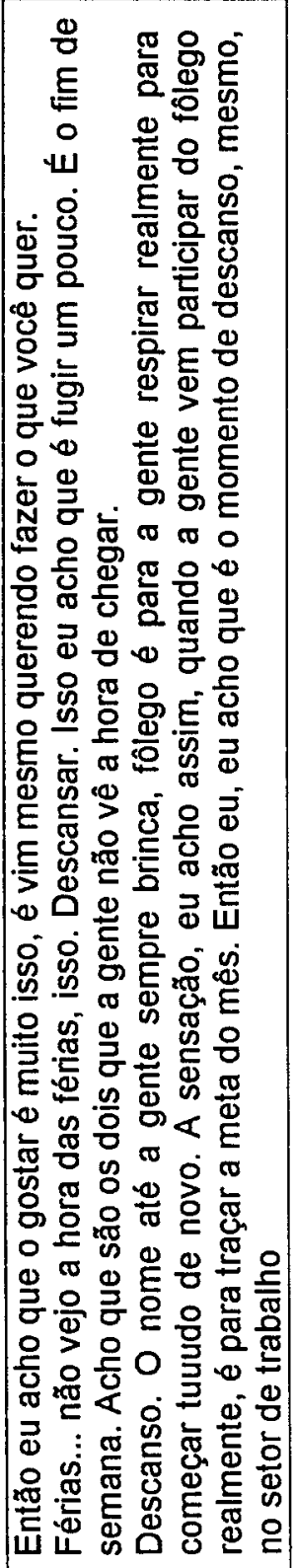 \\
\hline & 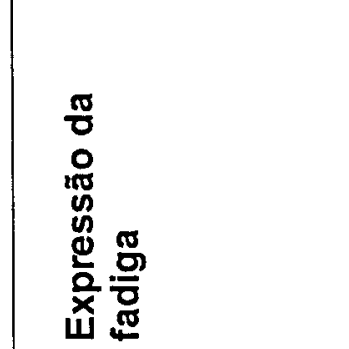 & 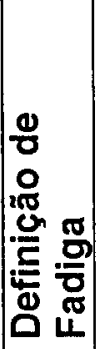 & 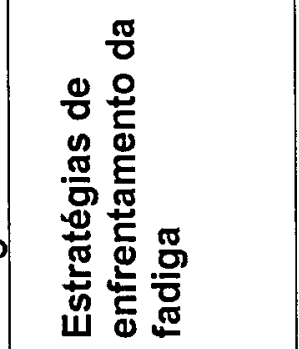 \\
\hline
\end{tabular}




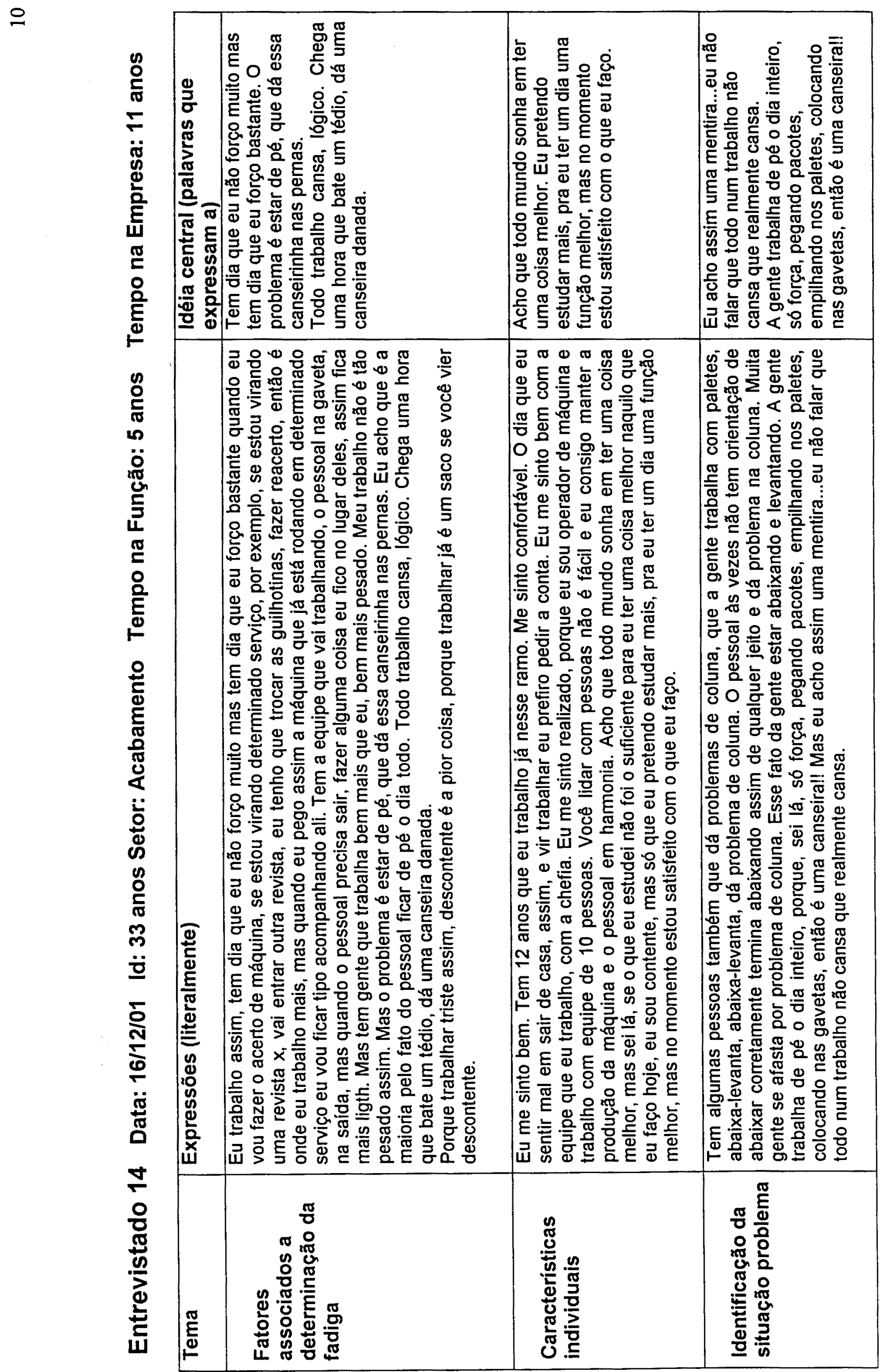




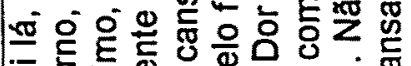

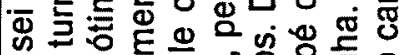
응

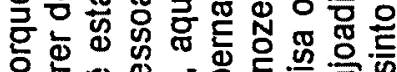
政 要

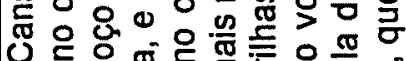
西 政

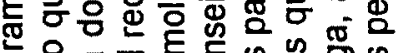

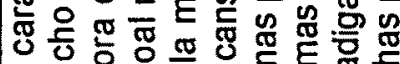

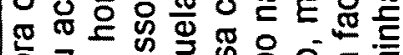
훙

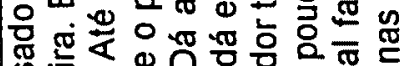
作

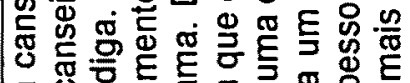
要 \%

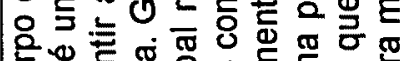

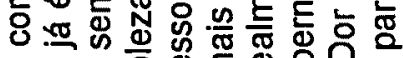
उ。ำ E 政

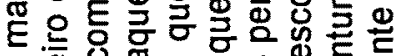

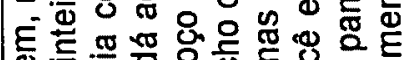
品

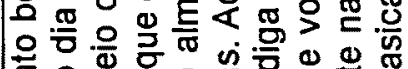

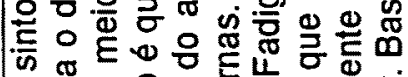
政

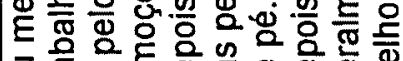

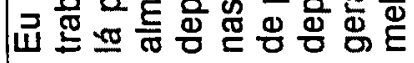

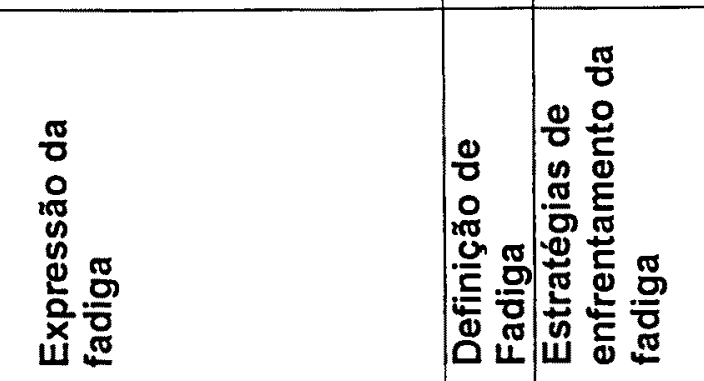




\section{$\simeq$}

\begin{tabular}{|c|c|c|c|c|c|c|}
\hline 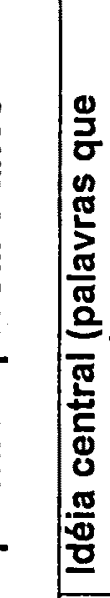 & 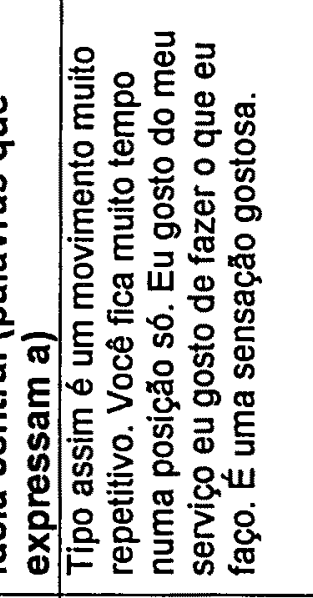 & 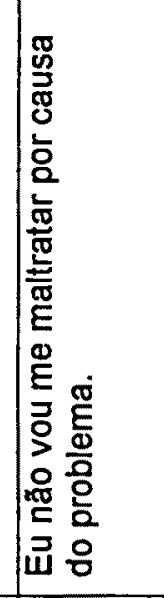 & 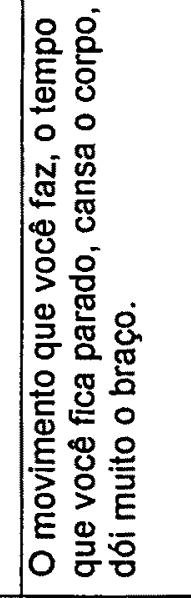 & 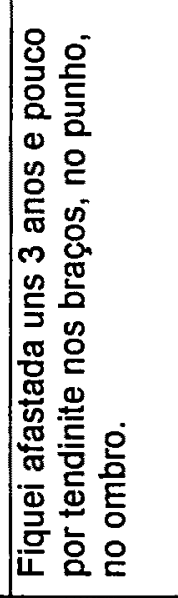 & & 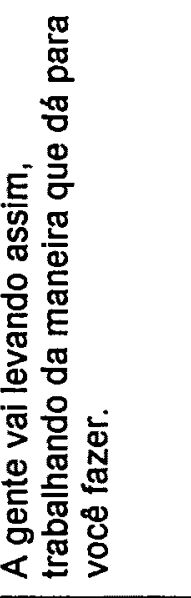 \\
\hline 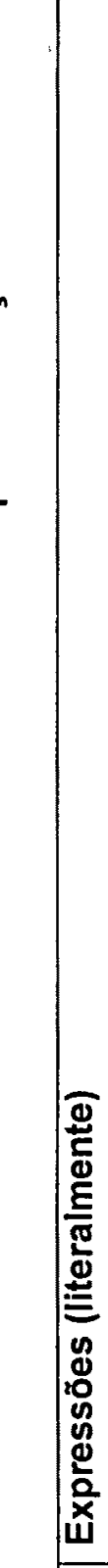 & 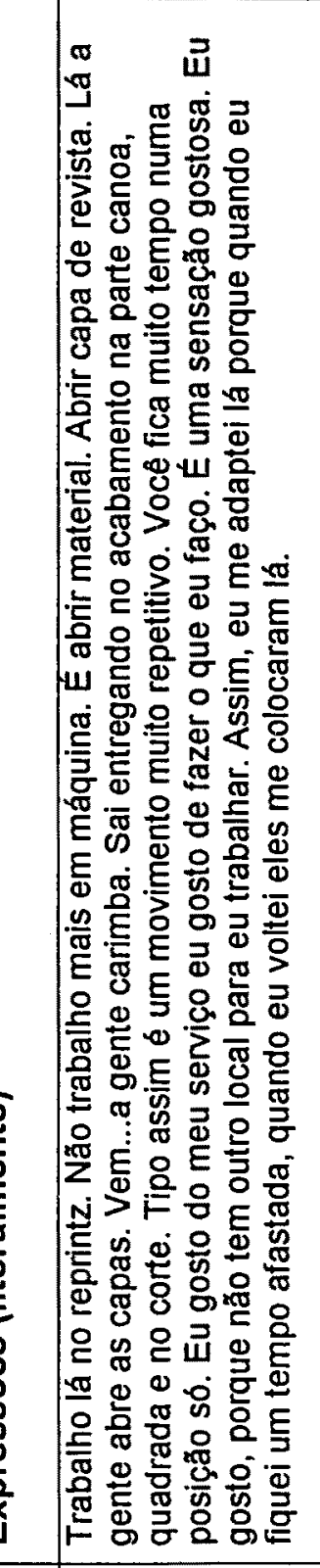 & 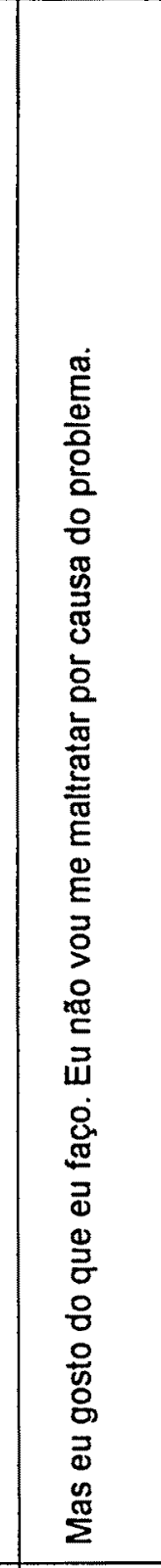 & 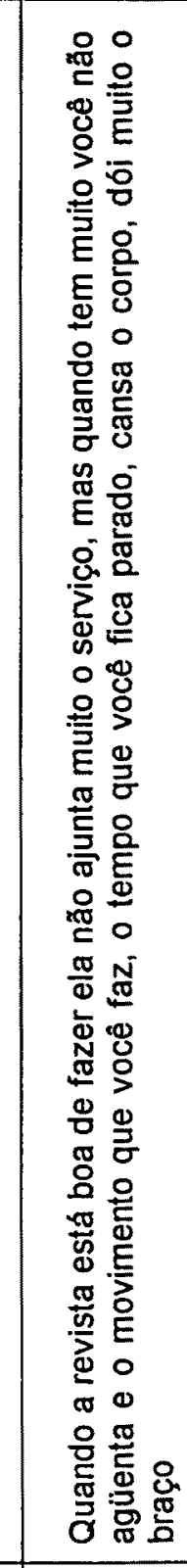 & 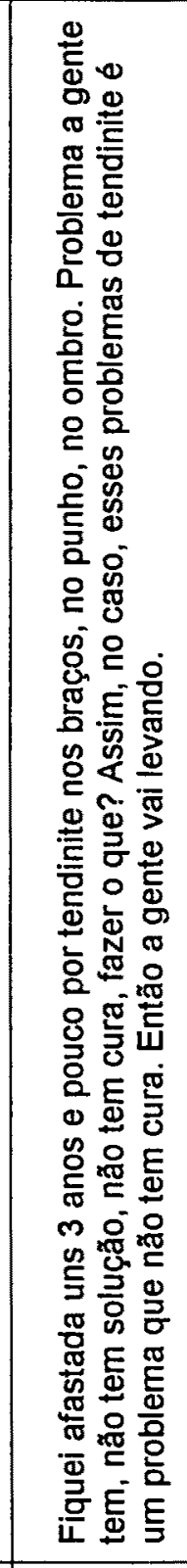 & & 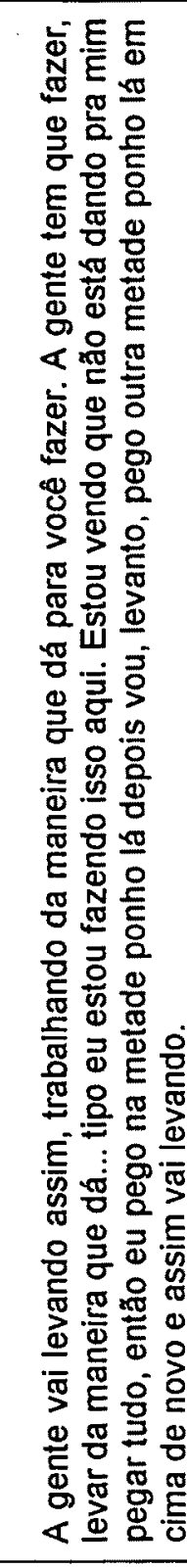 \\
\hline$\tilde{\mathscr{\sigma}}$ & 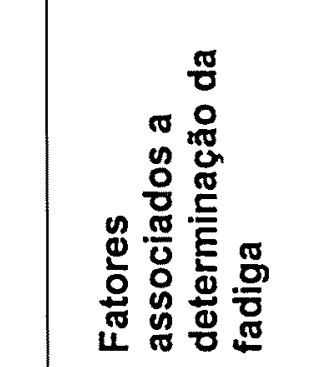 & 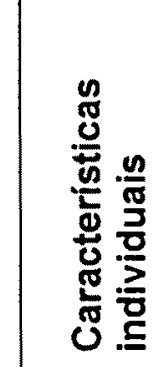 & 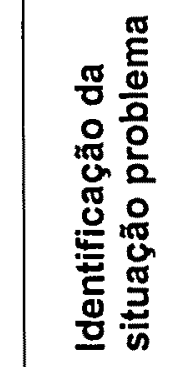 & 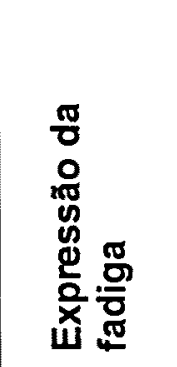 & 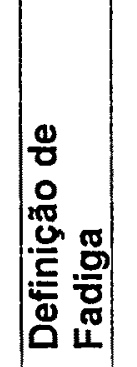 & 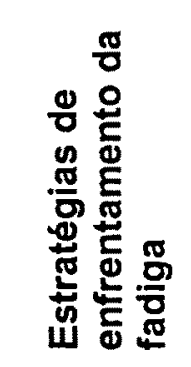 \\
\hline
\end{tabular}




\begin{tabular}{|c|c|c|c|c|}
\hline 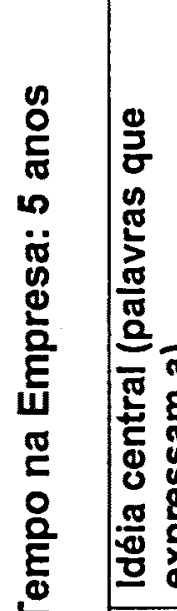 & 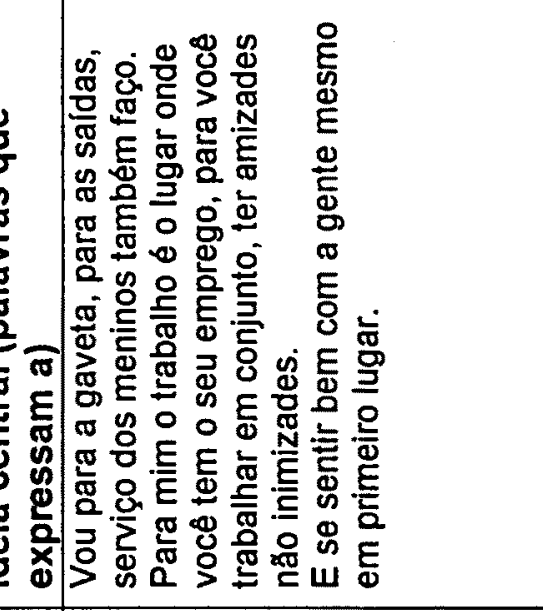 & 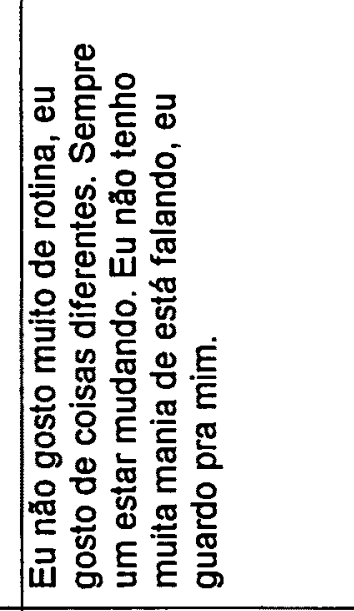 & 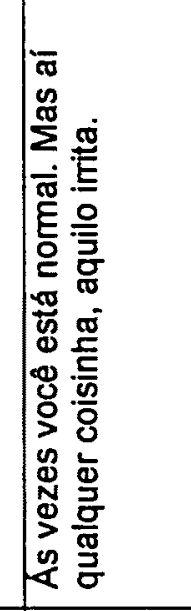 & 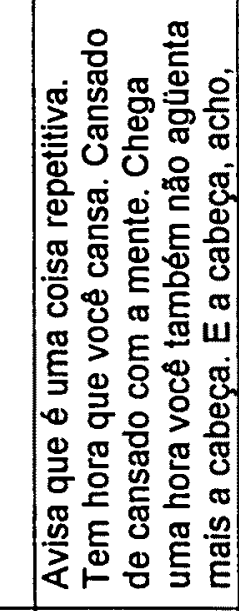 \\
\hline & 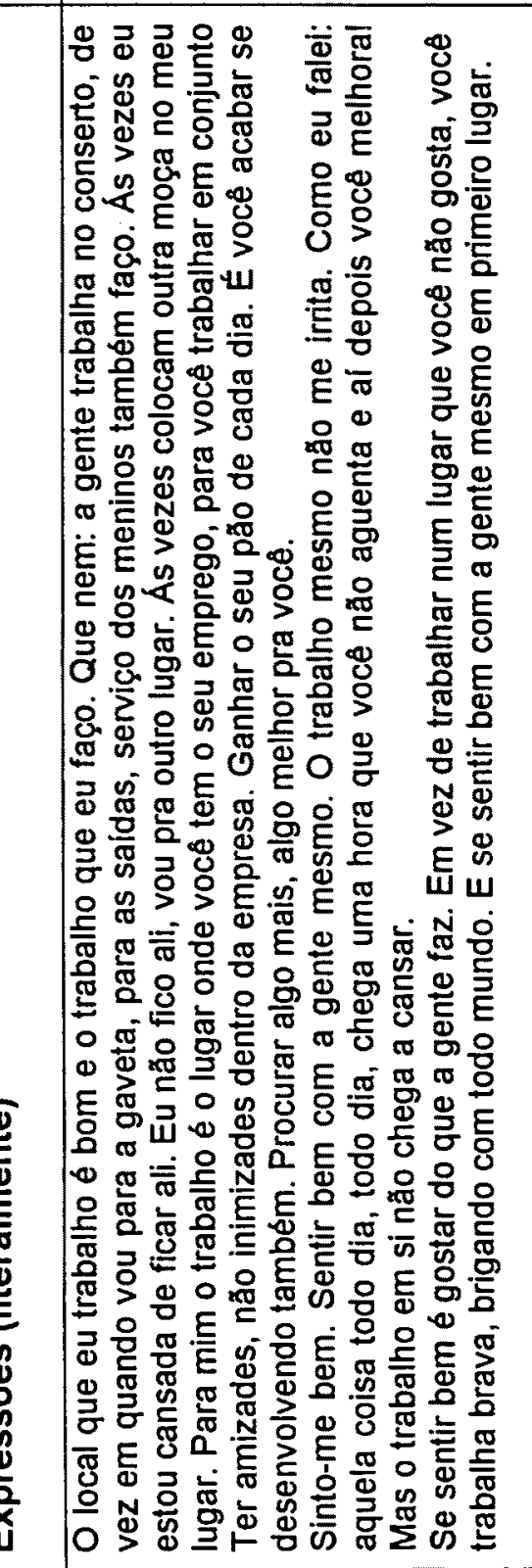 & 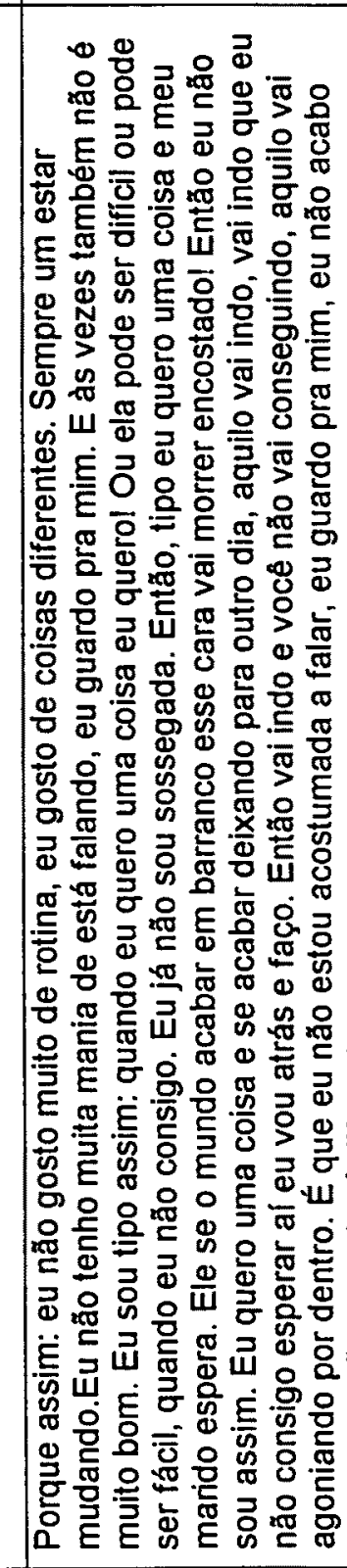 & 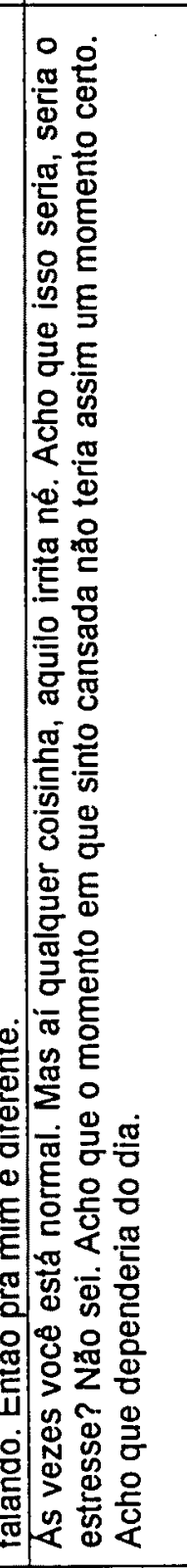 & 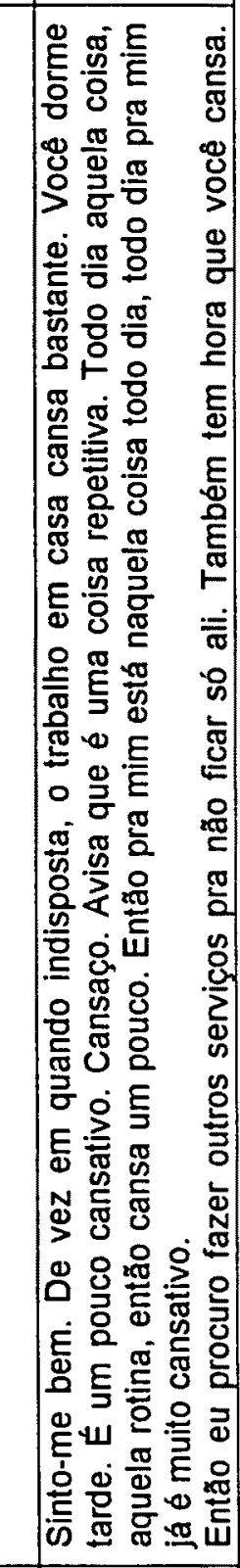 \\
\hline & 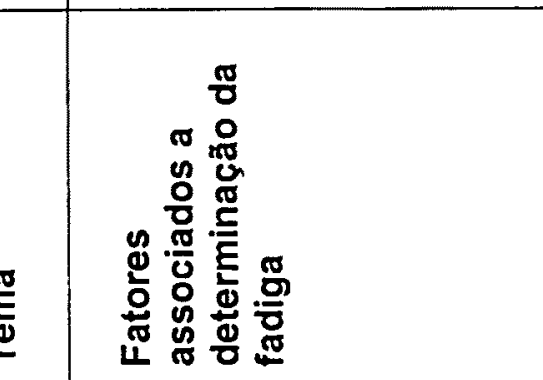 & 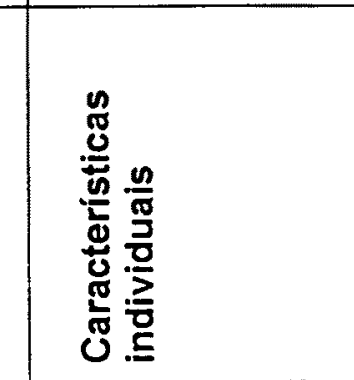 & 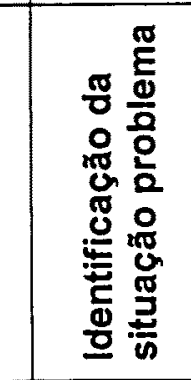 & 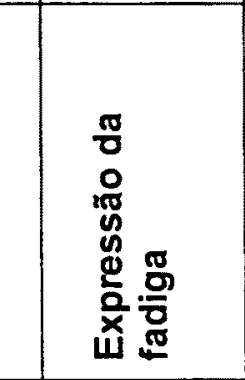 \\
\hline
\end{tabular}




\begin{tabular}{|c|c|c|}
\hline 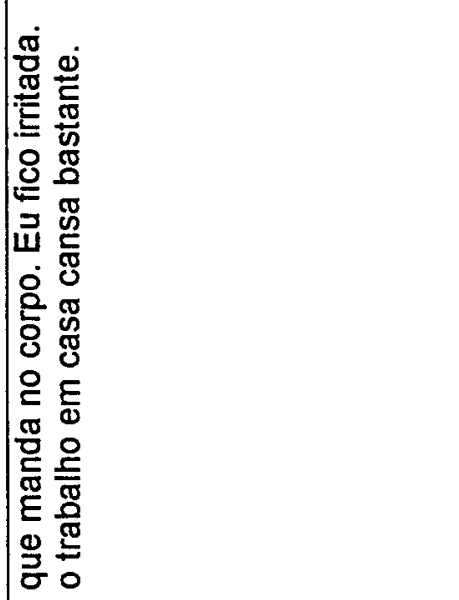 & & 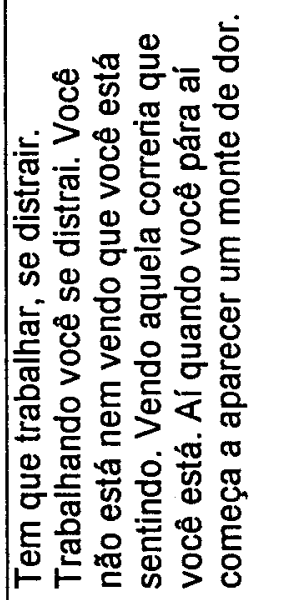 \\
\hline 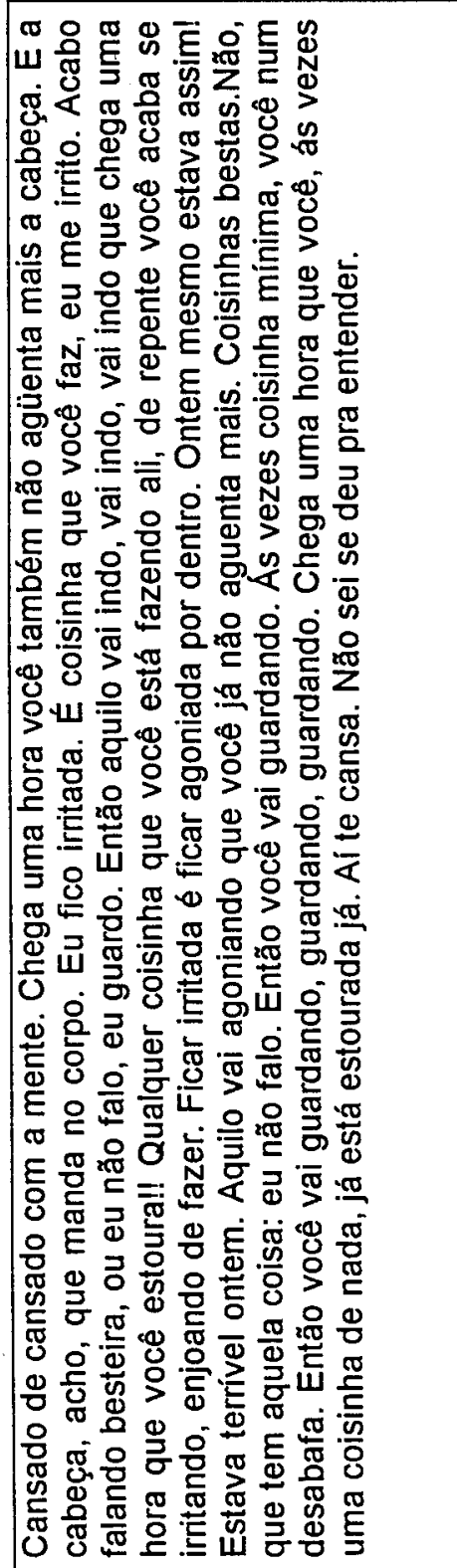 & & 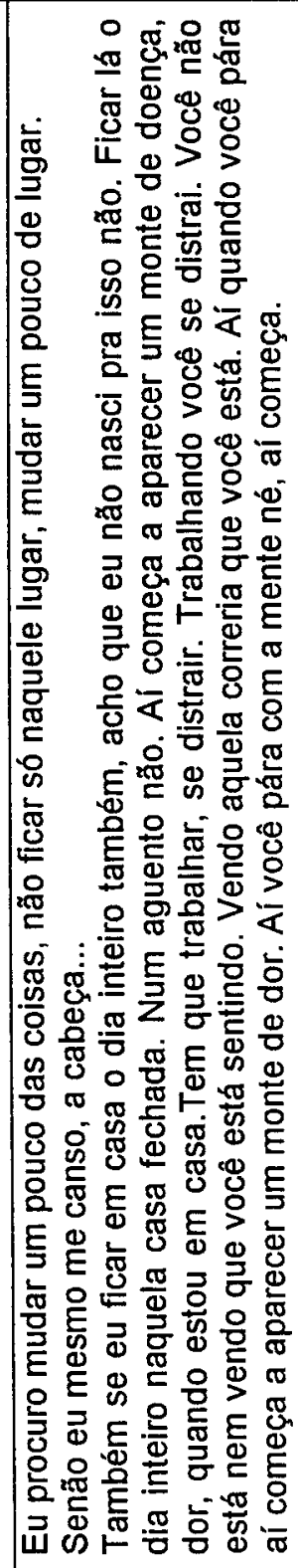 \\
\hline 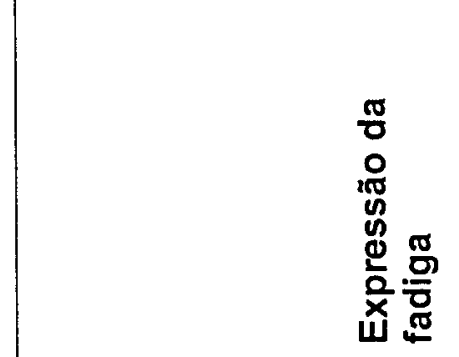 & 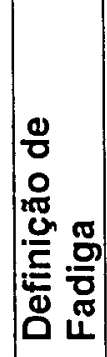 & 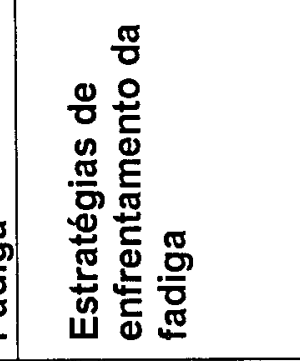 \\
\hline
\end{tabular}




\begin{tabular}{|c|c|c|c|c|c|}
\hline 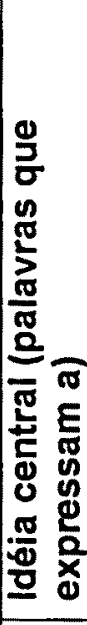 & 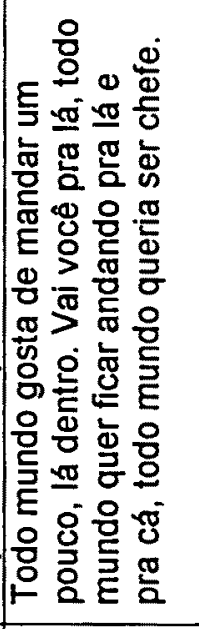 & 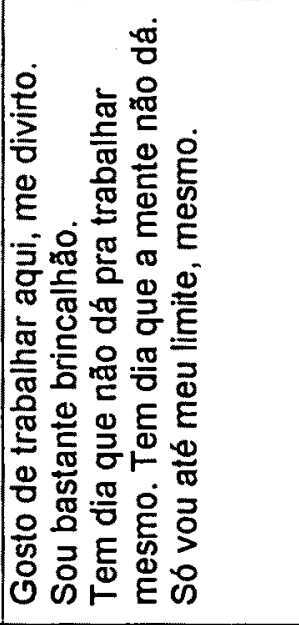 & 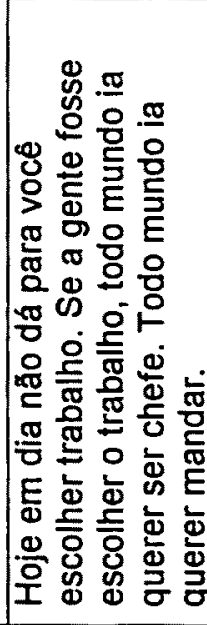 & 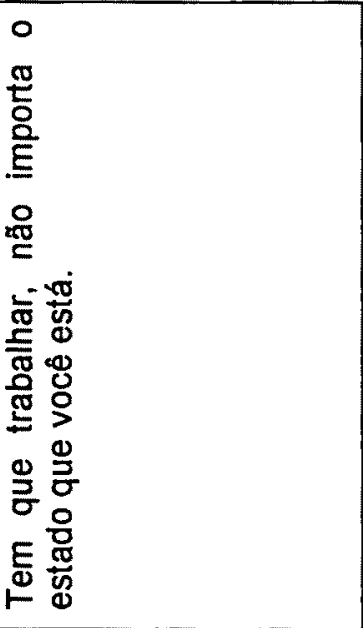 & 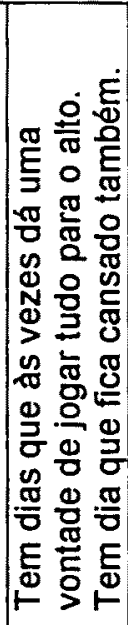 \\
\hline 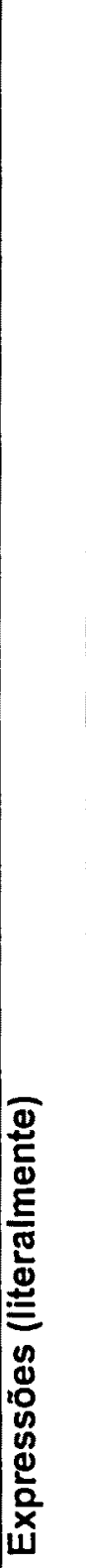 & 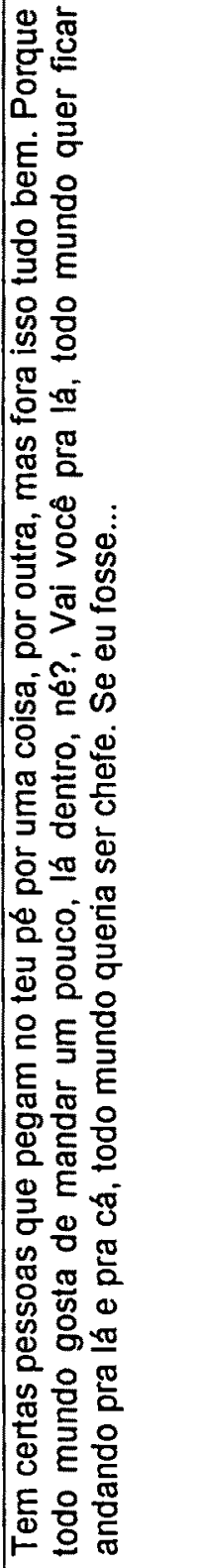 & 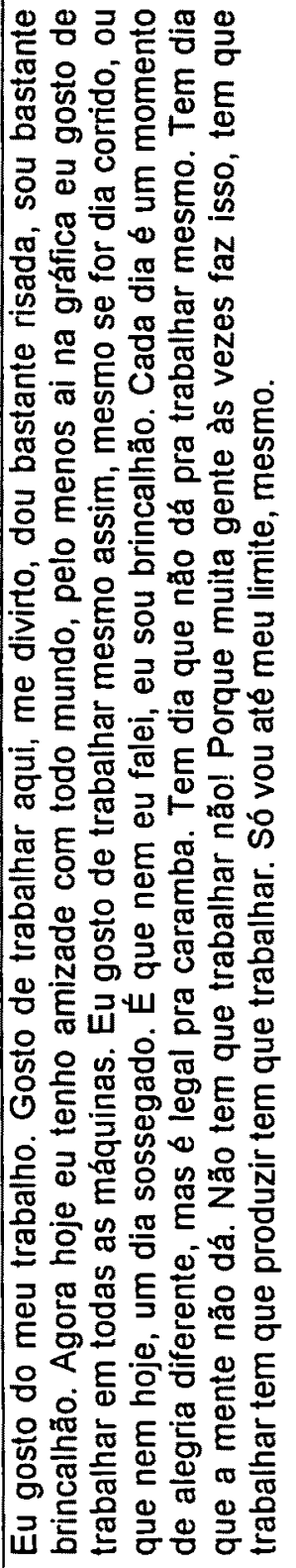 & 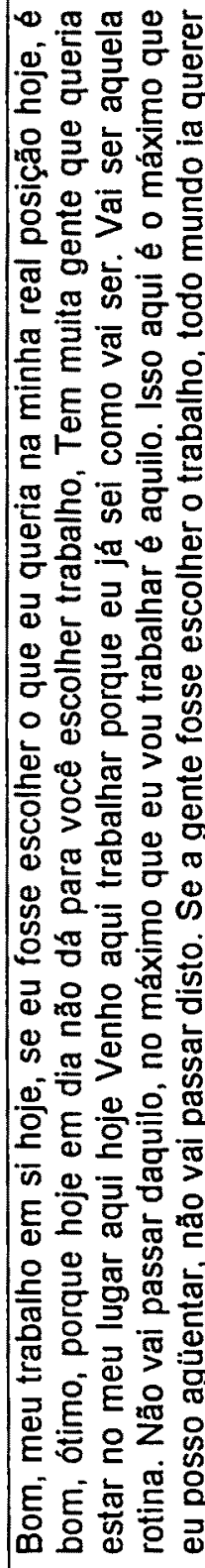 & 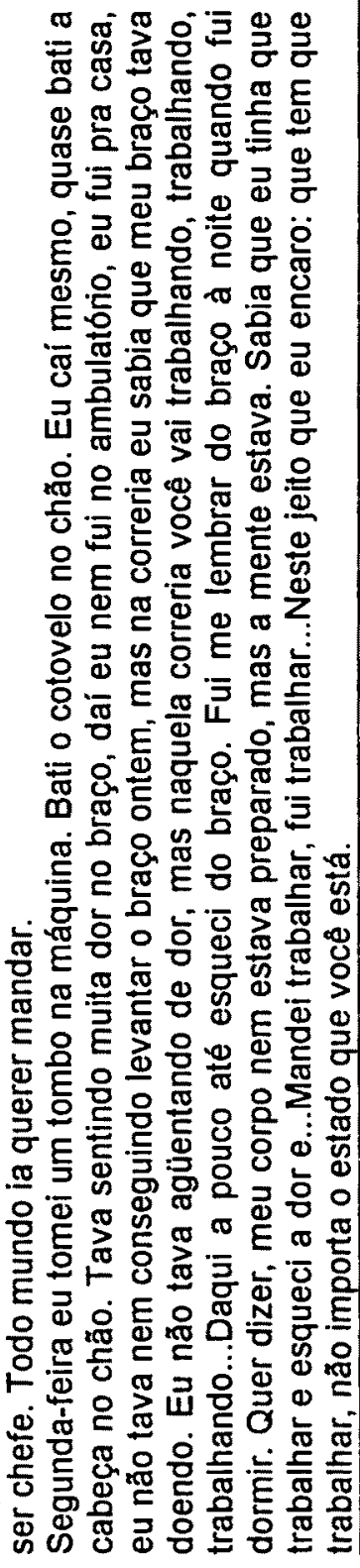 & 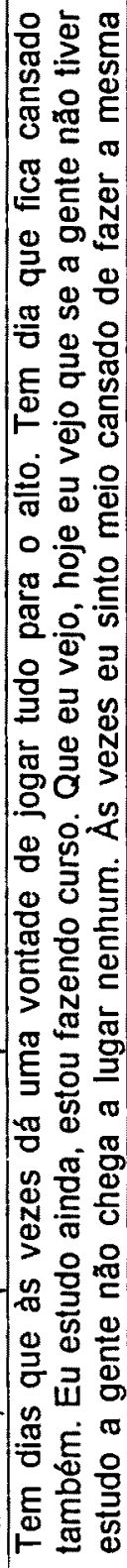 \\
\hline$\underset{\mathbb{E}}{E}$ & 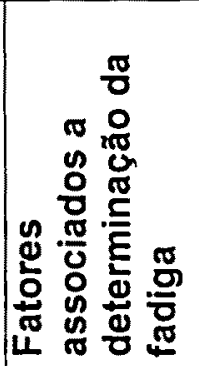 & 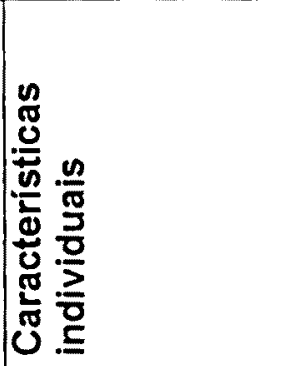 & 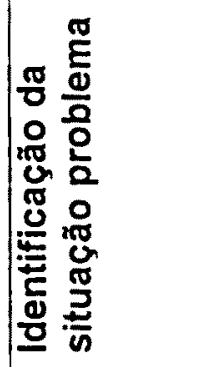 & & 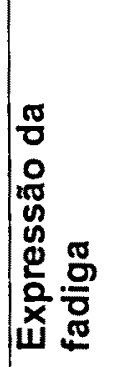 \\
\hline
\end{tabular}




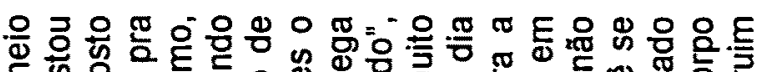

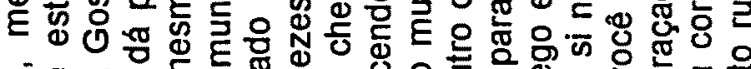

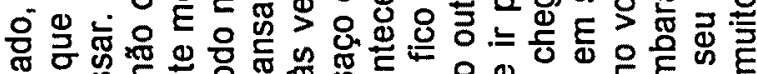

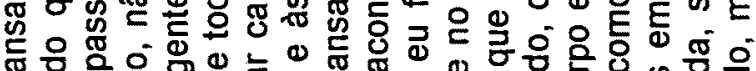

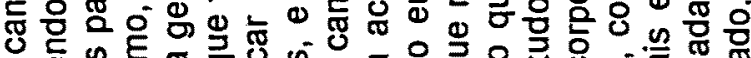
造饮

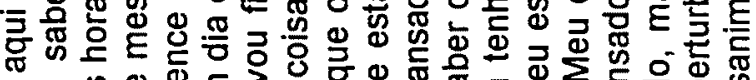

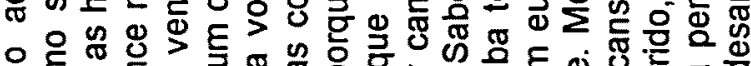

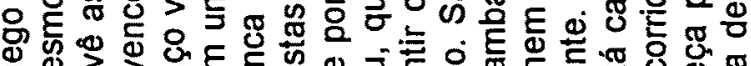

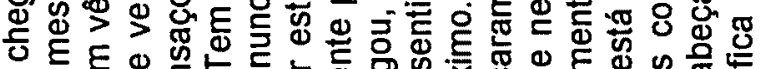

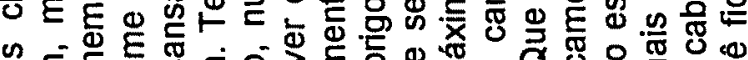
象

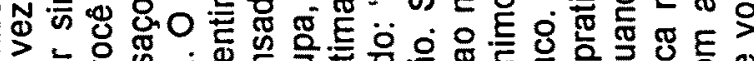

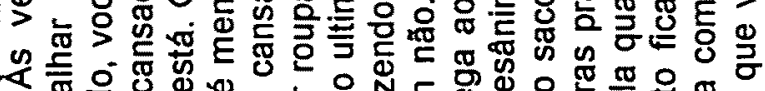

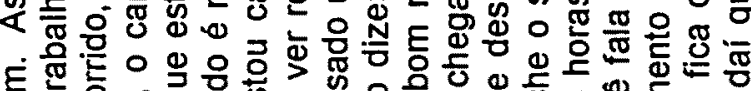

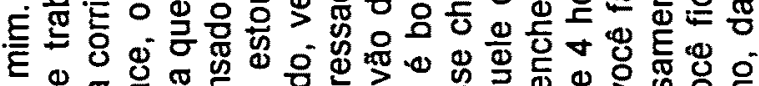

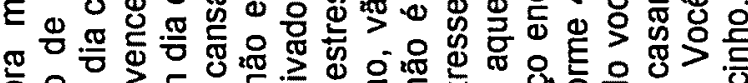

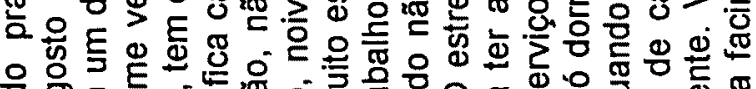

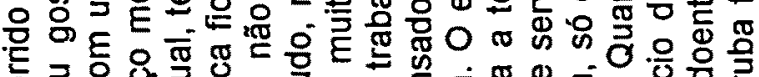

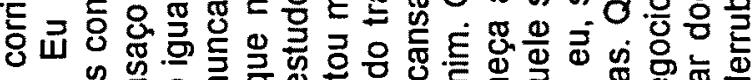

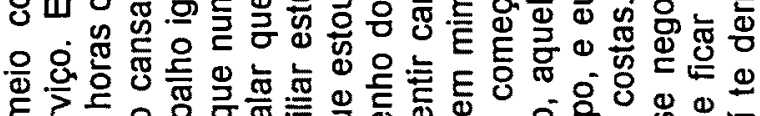

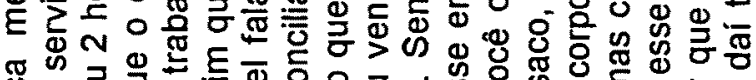

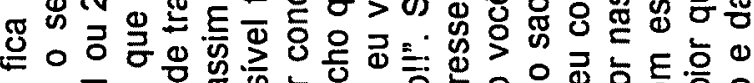

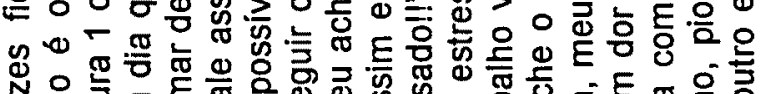

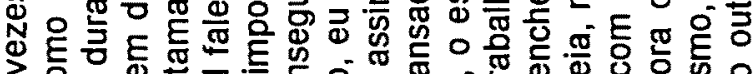
7 .

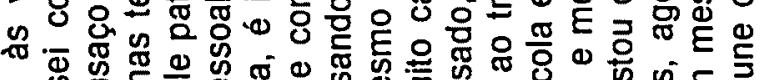

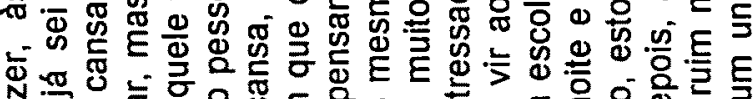

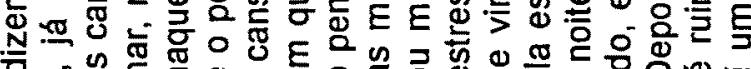
$\begin{array}{lll} & \\ 0 & \\ 0\end{array}$

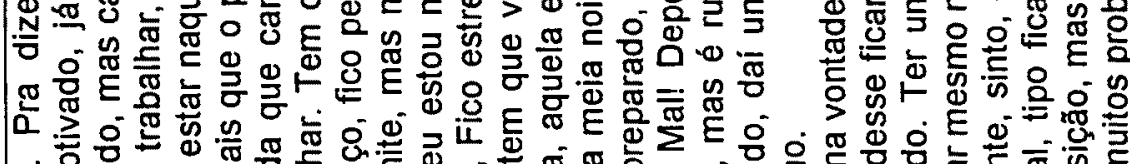

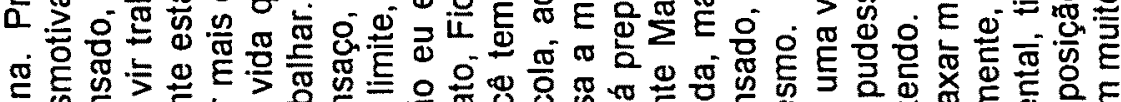

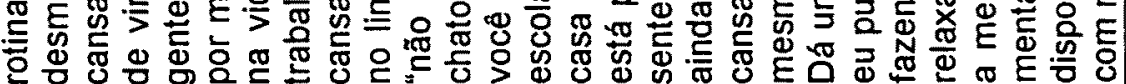

Ф๐ ま

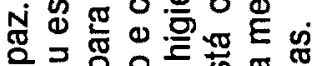

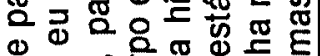

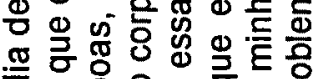
은 至 육 응 을 즐

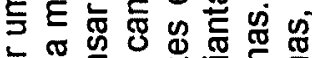

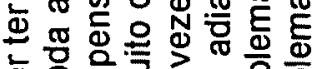
흐응응

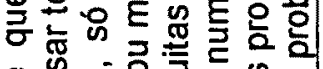

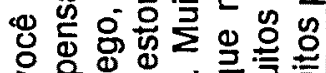
管 을틀

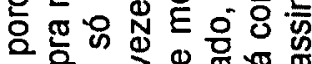

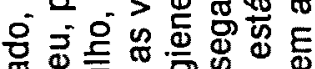

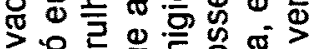
告品 오을 \%

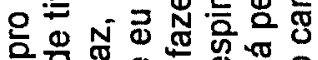

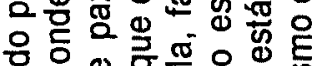

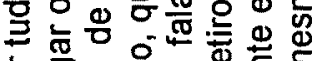

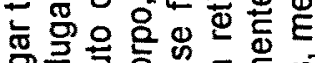
을 व

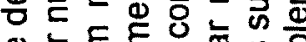
두의 政

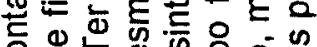

E⿸厂二 욜 인 竞는

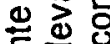
政

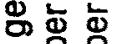
क $\frac{1}{8}$ 응 政 政 E

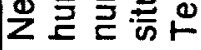

.
号导

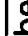

急

.
ฮั 으ㅇㅝㅡ 을 है 음 W 은 융요 돋 옹을 त ๙ 틍 웡 응 엉 웡응 웡

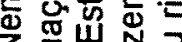

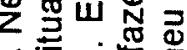
휴 ๘ 呟要 금은 응 응 틍 잉

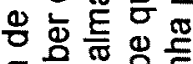

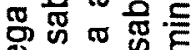
Ш ๑ 800

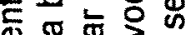
ठह एँ ๙ 을 응뵤용 을 둔

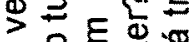
눈 으는 Nㅡㄴ

\begin{tabular}{|c|c|c|}
\hline 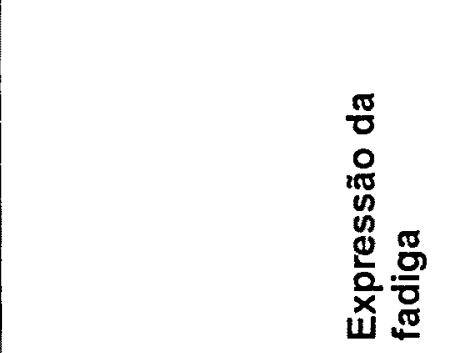 & 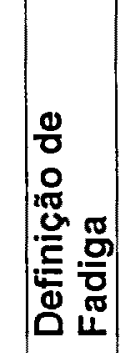 & 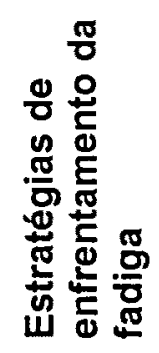 \\
\hline
\end{tabular}




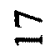

言

ब্

a

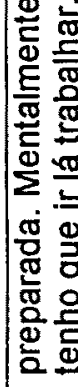

言家 음

亩

商

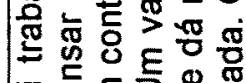

뜌 ญ

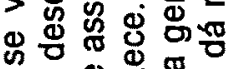

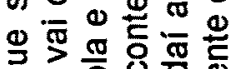

吕

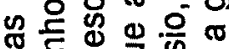

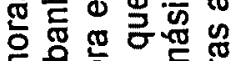

틈

응 틍 훙응 행

น

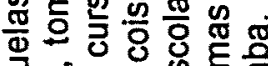

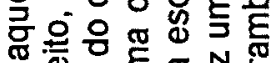

ชั.

冚

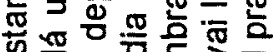

.

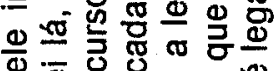

ब 0 ○

品

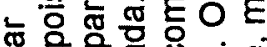

능 융

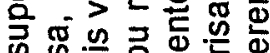

๘

立

ชั

뜬

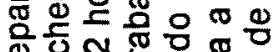

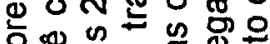

ญ ․ㅡ원

๘

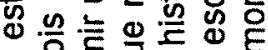

웜 응 흥

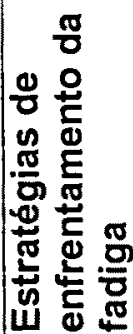




\section{ANEXO V}

Entrevistados sem Fadiga segundo a Escala de Fadiga de Chalder 


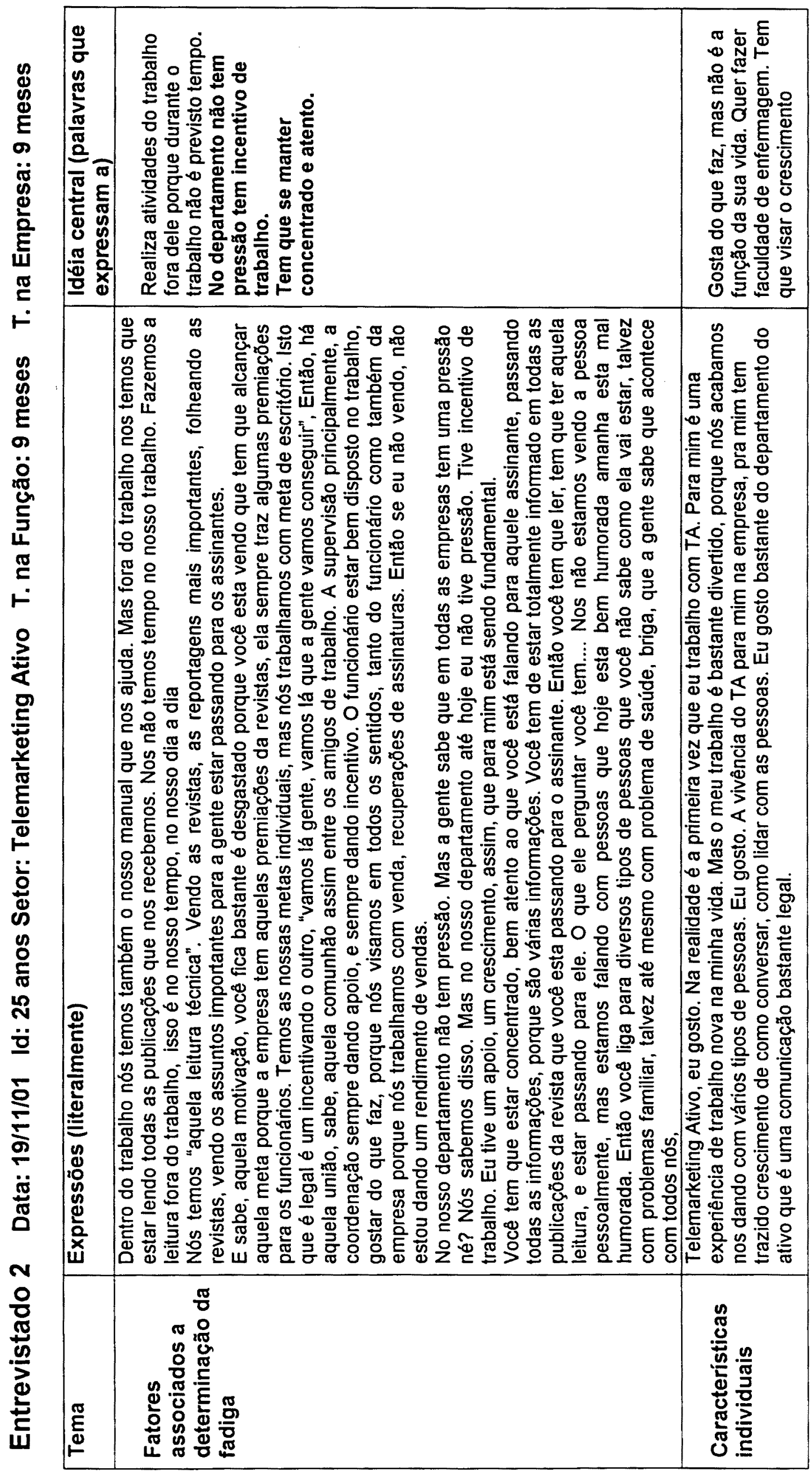




\begin{tabular}{|c|c|c|c|c|}
\hline & 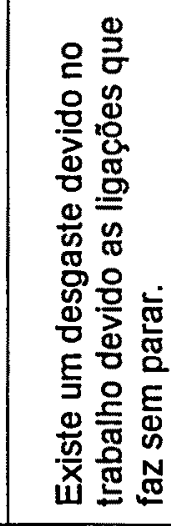 & 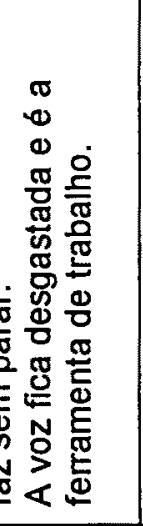 & & 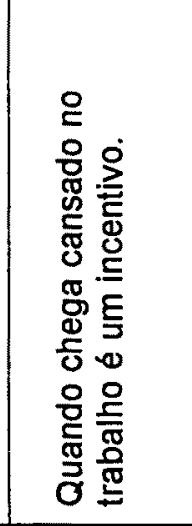 \\
\hline 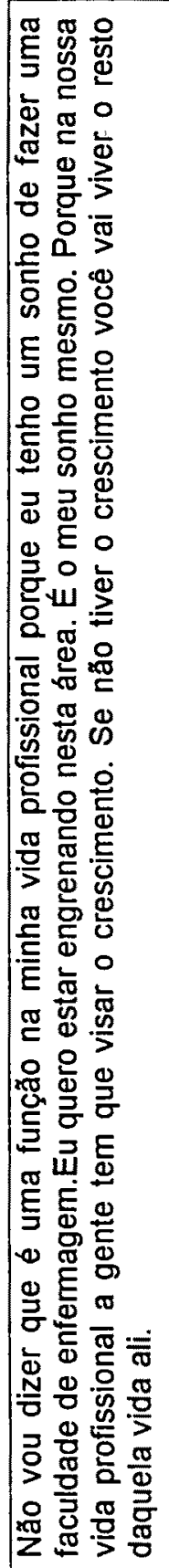 & 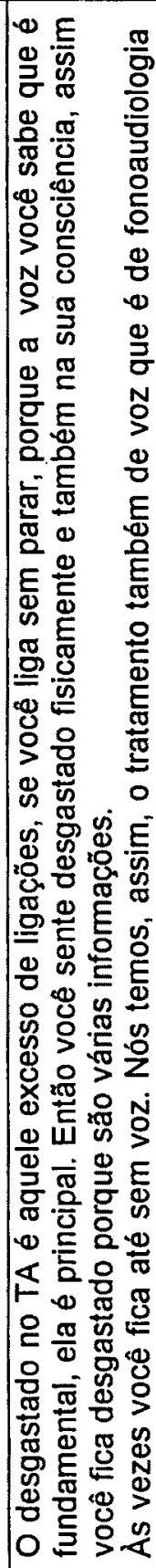 & 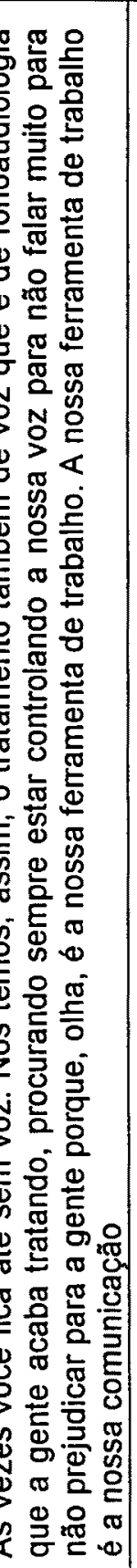 & & 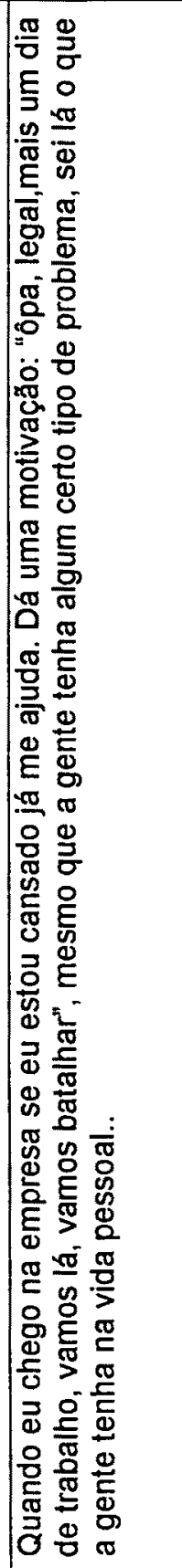 \\
\hline 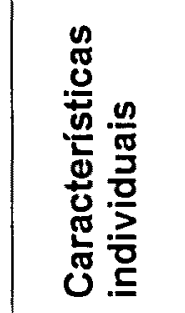 & 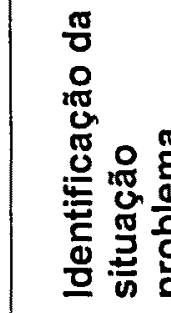 & $\bar{a}$ & 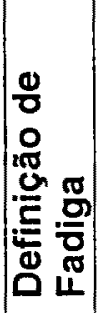 & 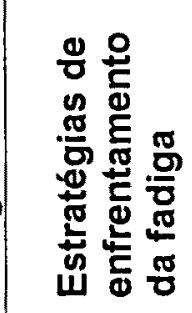 \\
\hline
\end{tabular}




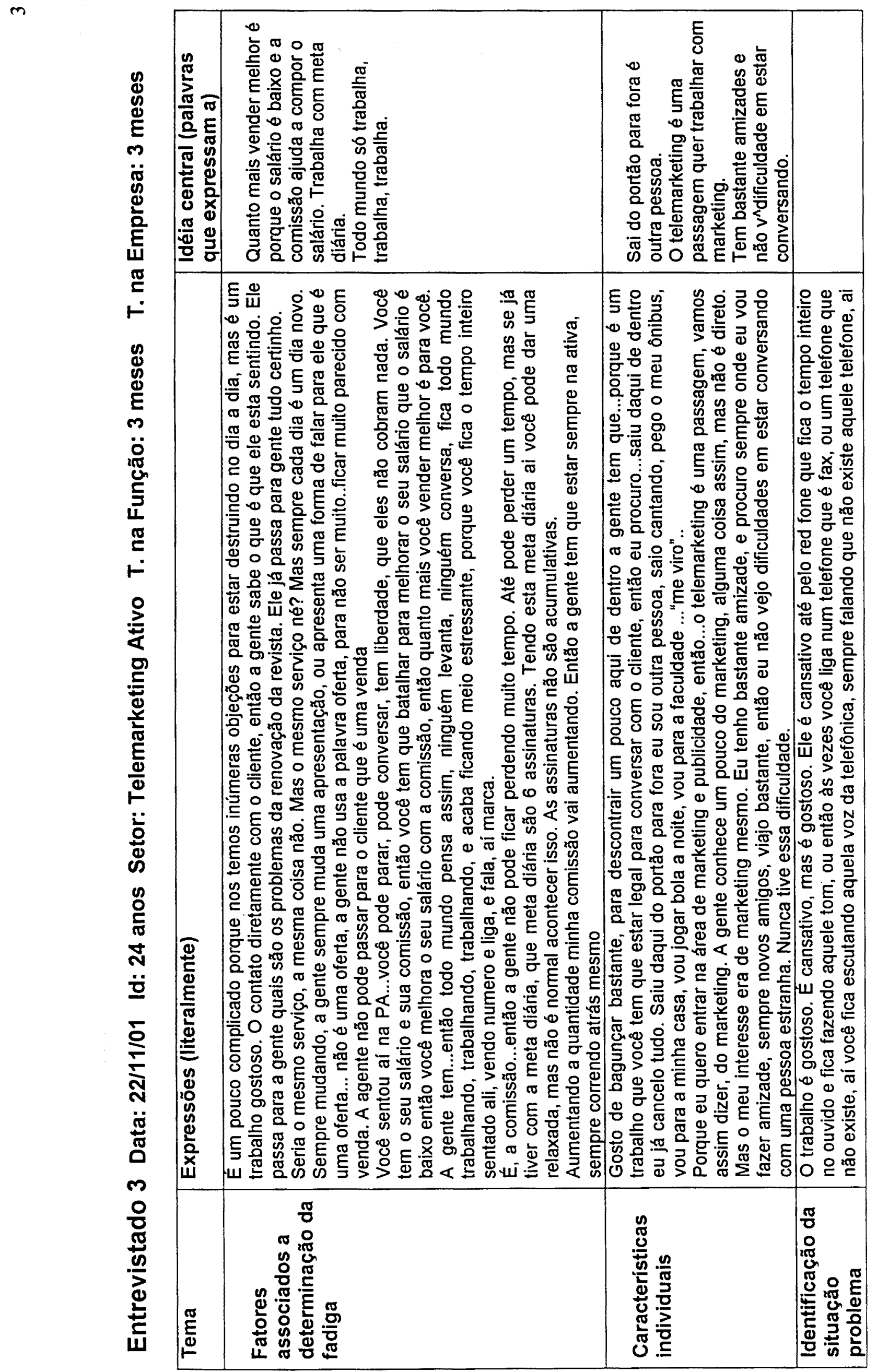




\begin{tabular}{|c|c|c|c|}
\hline 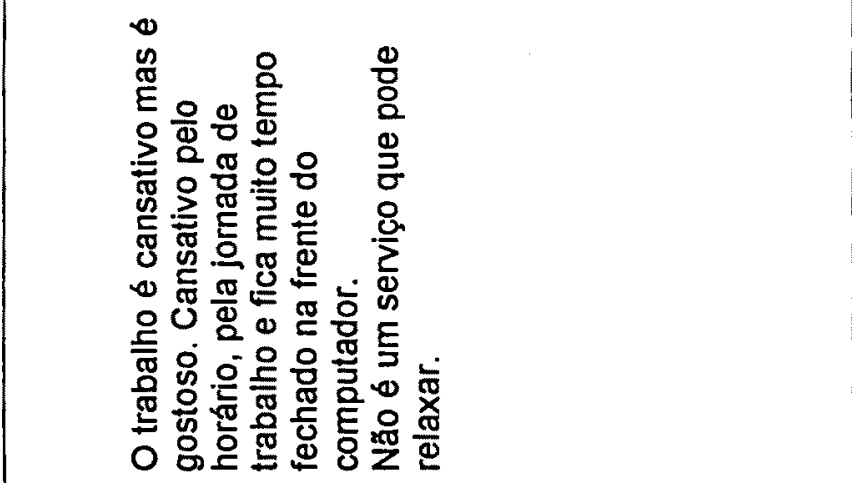 & 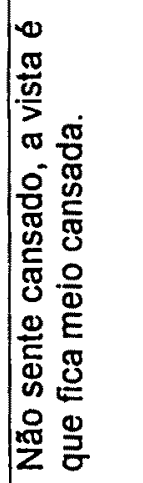 & & 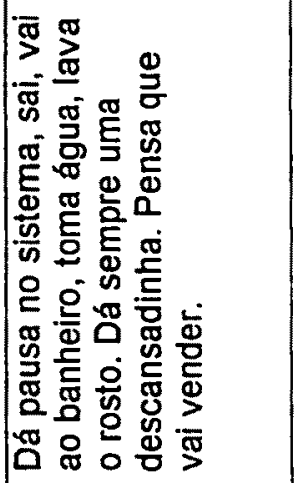 \\
\hline 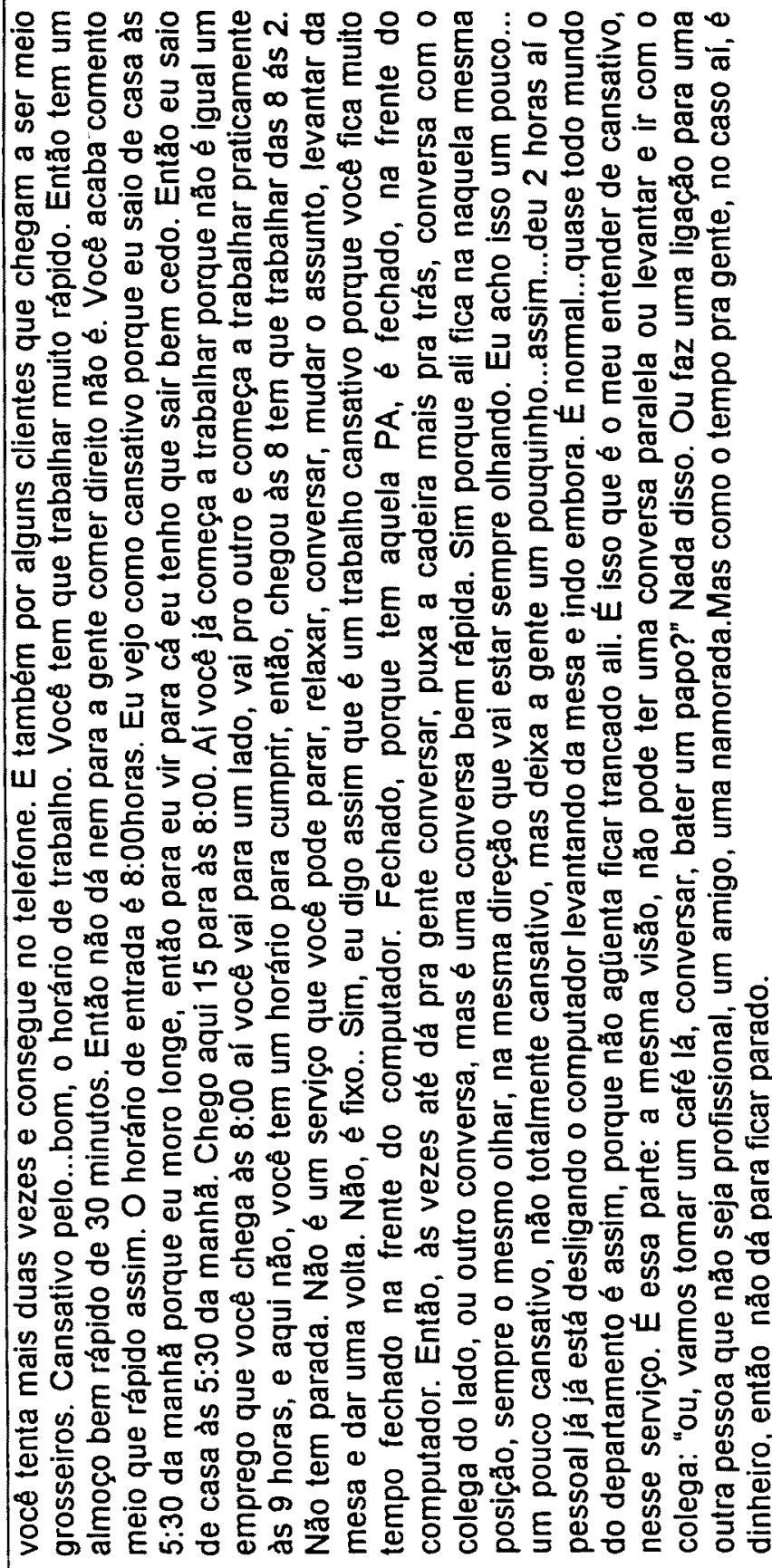 & 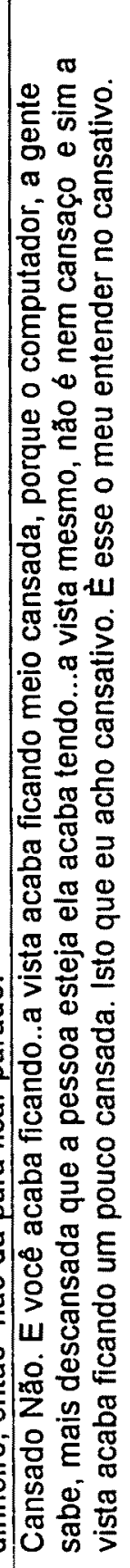 & & 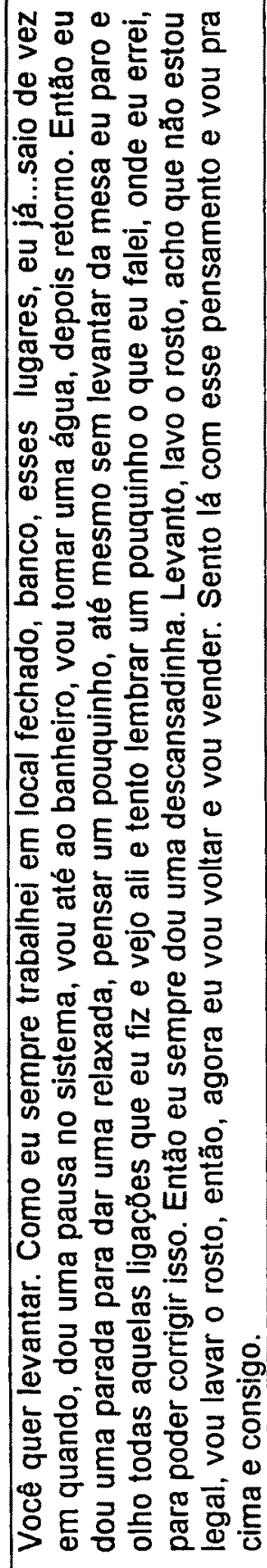 \\
\hline 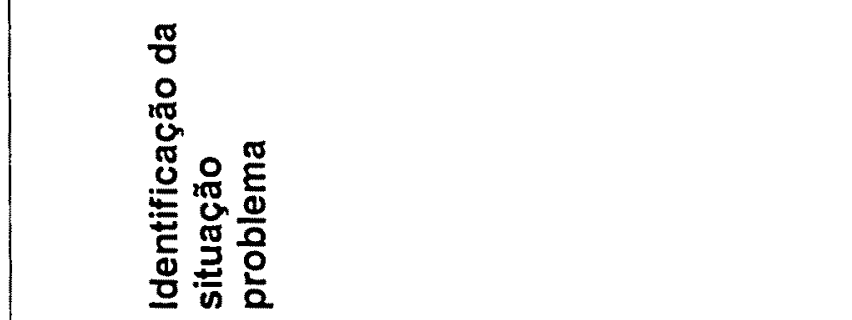 & 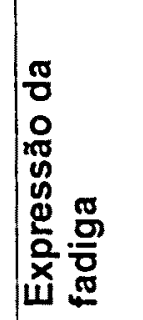 & 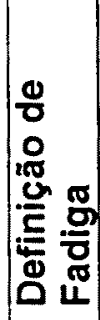 & 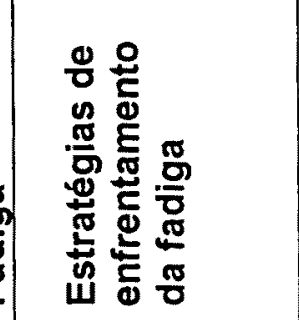 \\
\hline
\end{tabular}




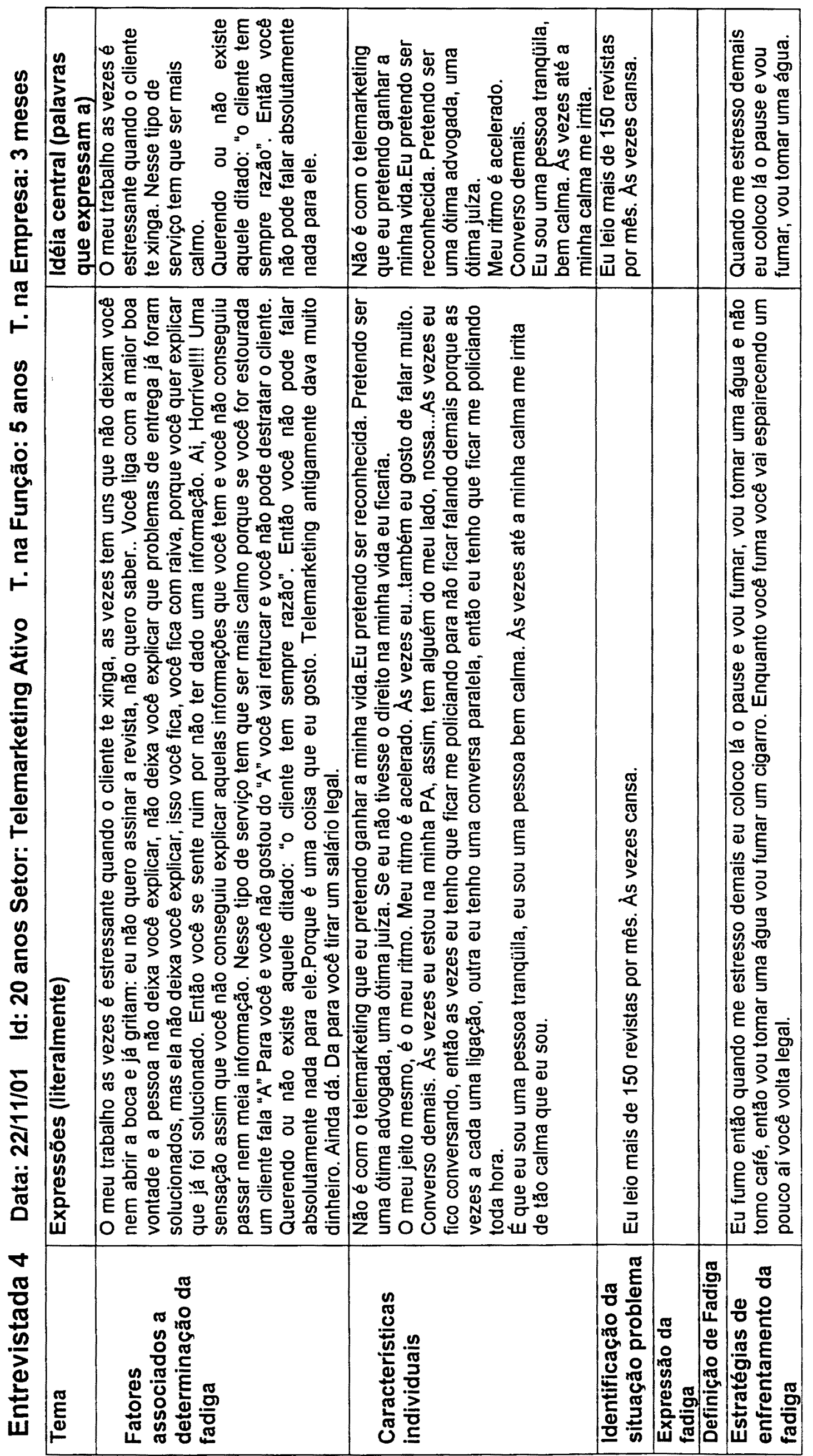




\begin{tabular}{|c|c|c|c|c|c|c|c|c|}
\hline 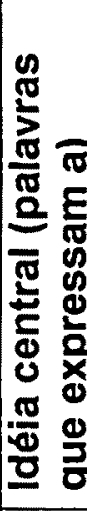 & 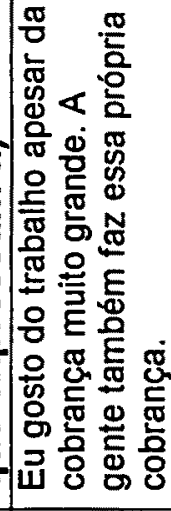 & 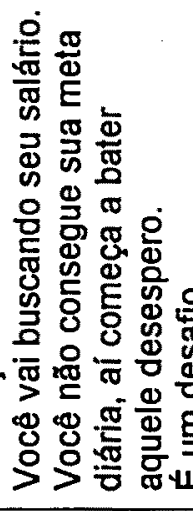 & & 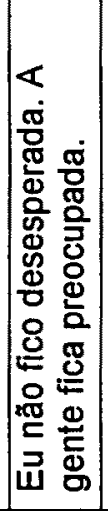 & & & & \\
\hline 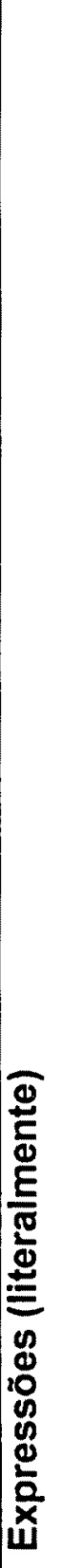 & 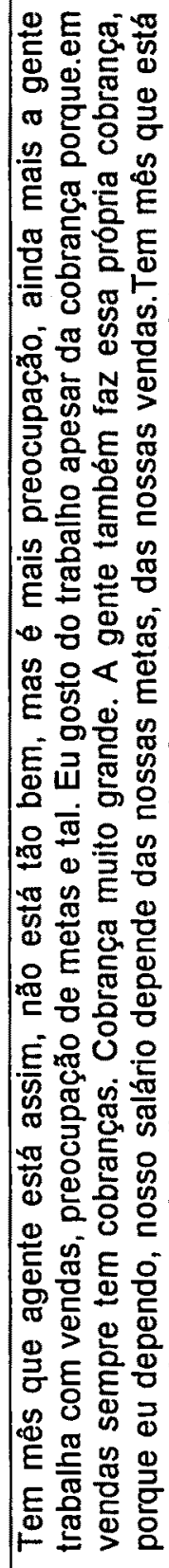 & 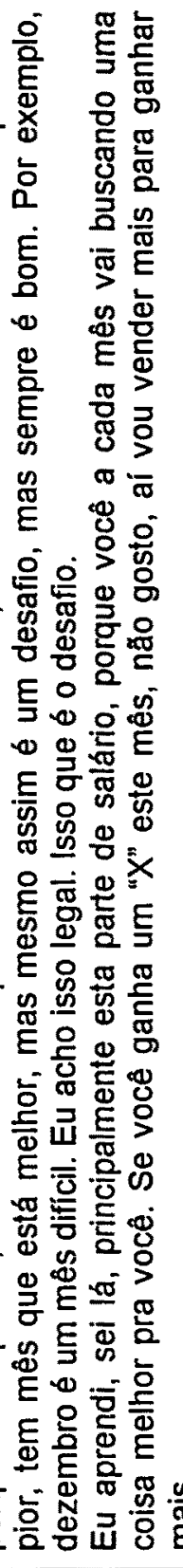 & 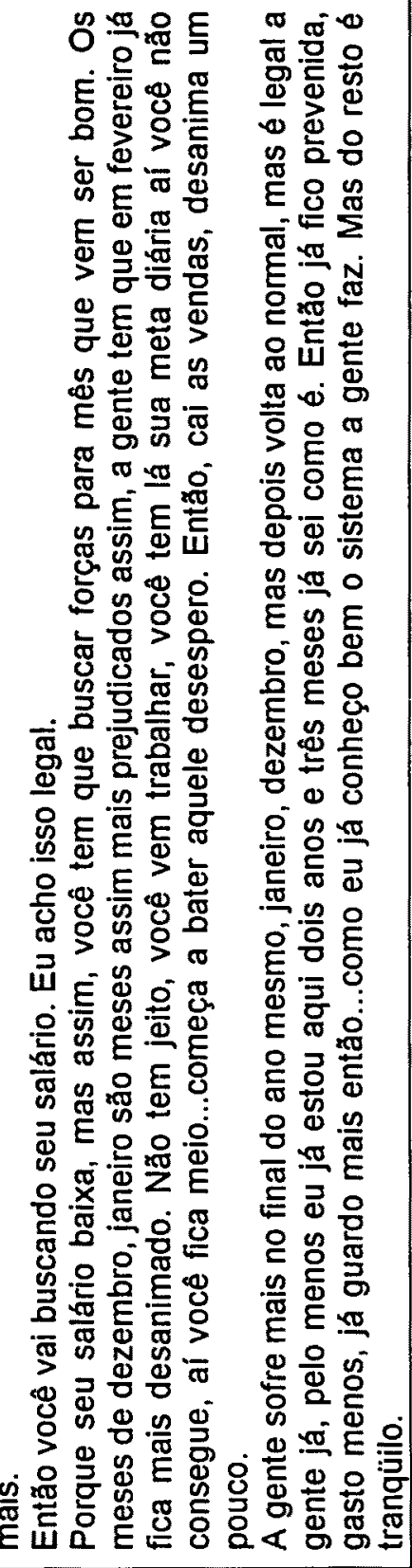 & 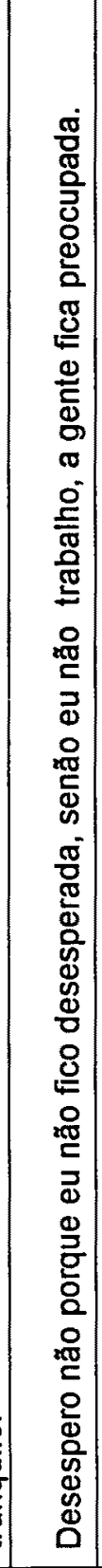 & & & & \\
\hline$\stackrel{\mathbb{E}}{\frac{\mathbb{E}}{\mathbf{E}}}$ & 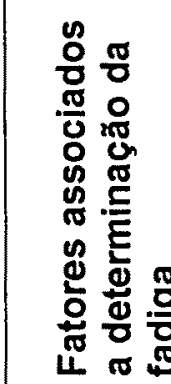 & & & 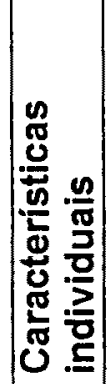 & 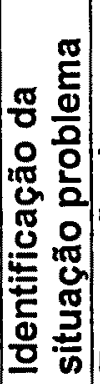 & 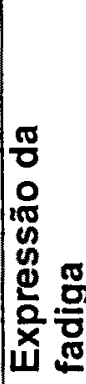 & 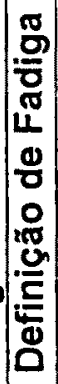 & 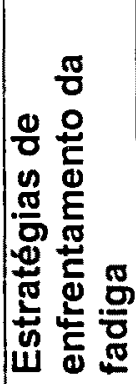 \\
\hline
\end{tabular}


$\frac{0}{0}$

ป

告

응

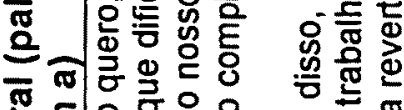

틔 운

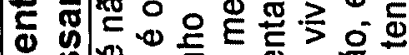

0 .

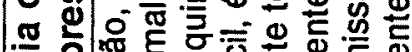

क्ष

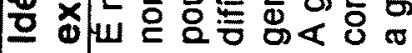

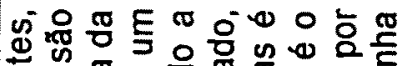

空

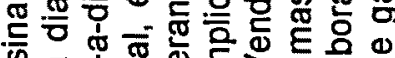

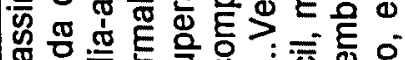

চ

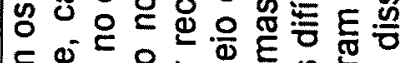

E 总

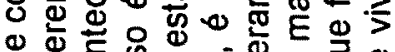

总产

ह

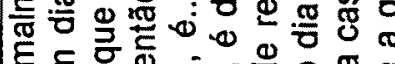

통

巡

过

离

đ

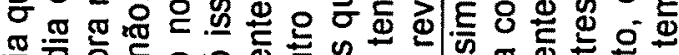

뜸 증응

๙

宁 す

은

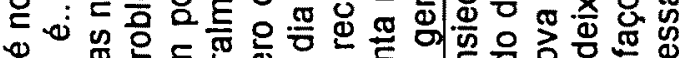

凹

훙

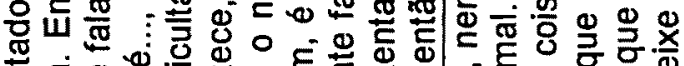

穹

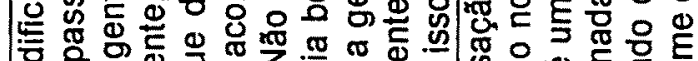

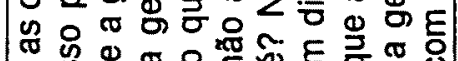

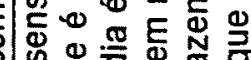

므

高

可

๙

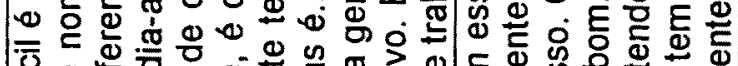

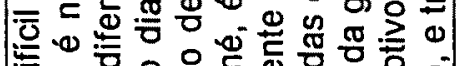

잉 约을

때유

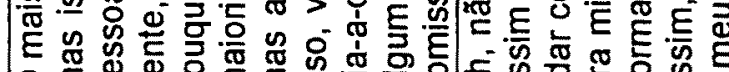

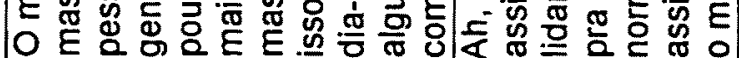
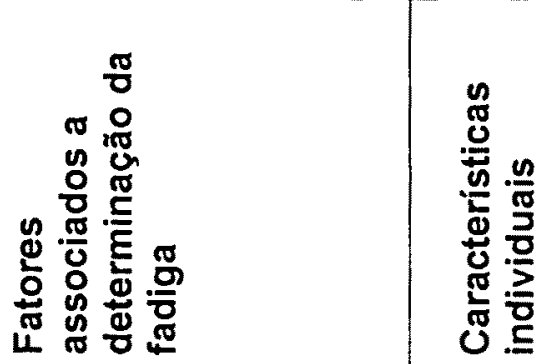

응 웅

c)

픔

\&

동

ธับ के 


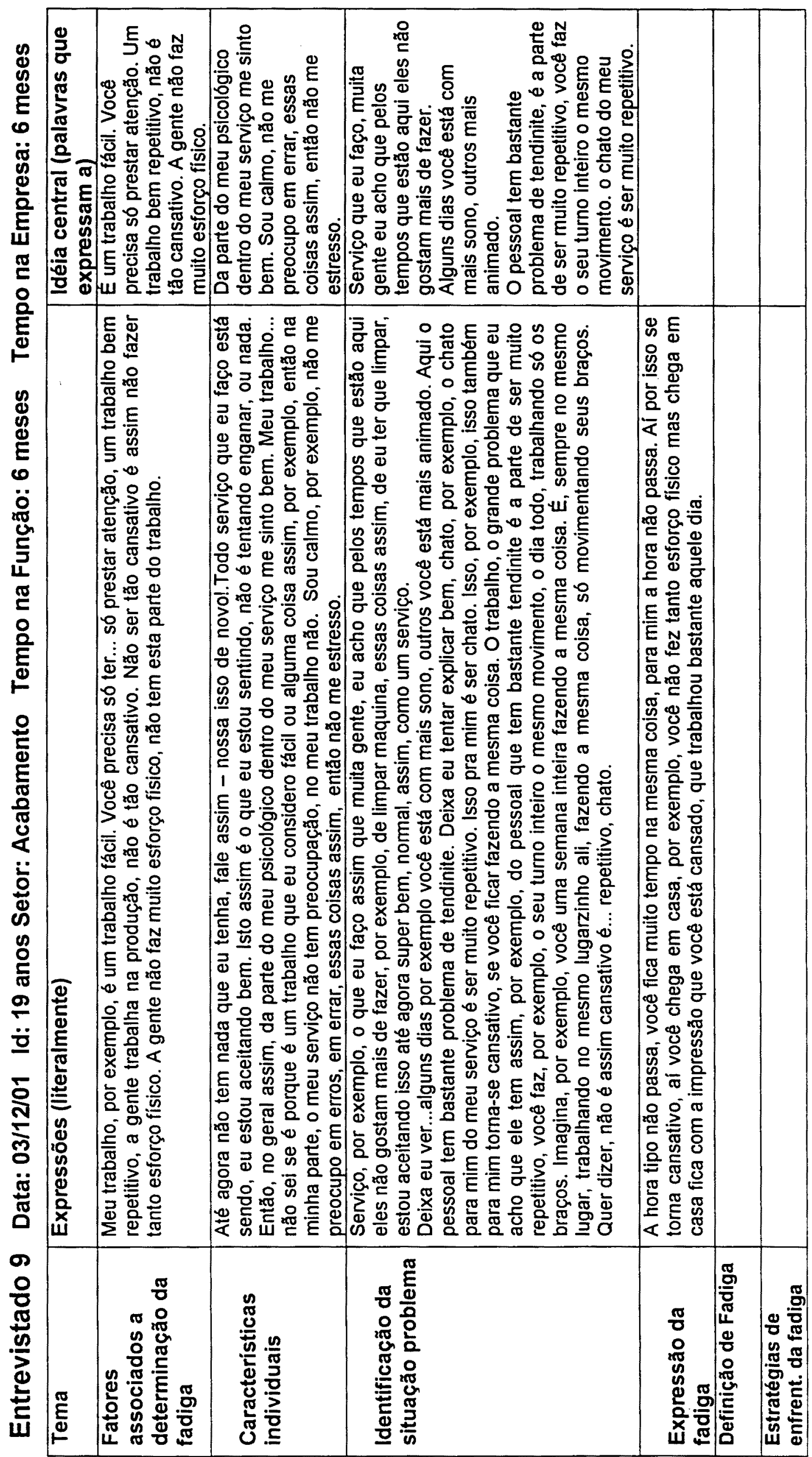




\begin{tabular}{|c|c|c|c|}
\hline 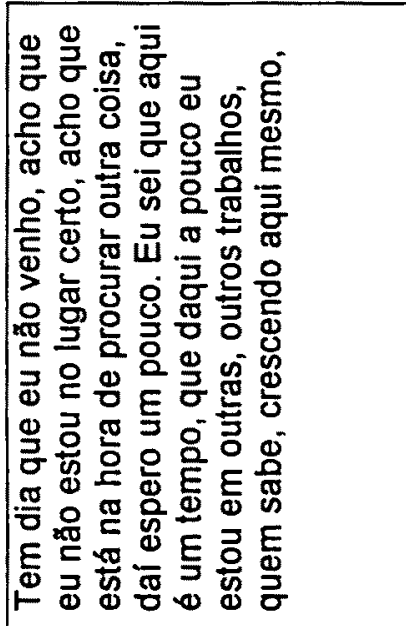 & 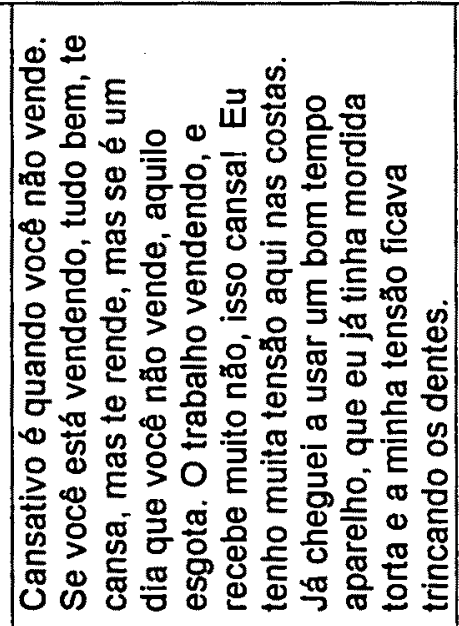 & & \\
\hline 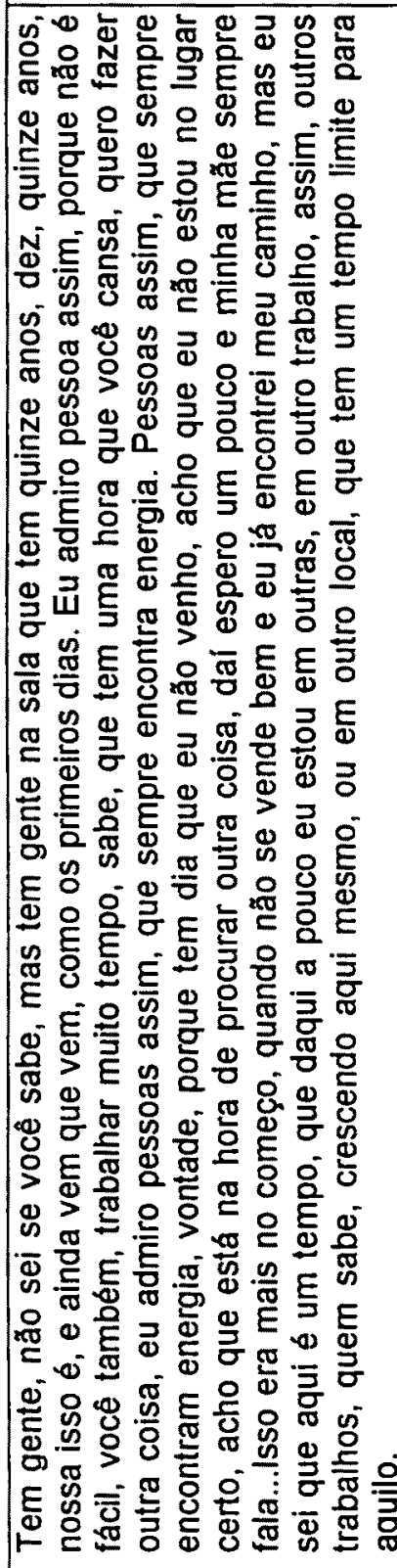 & 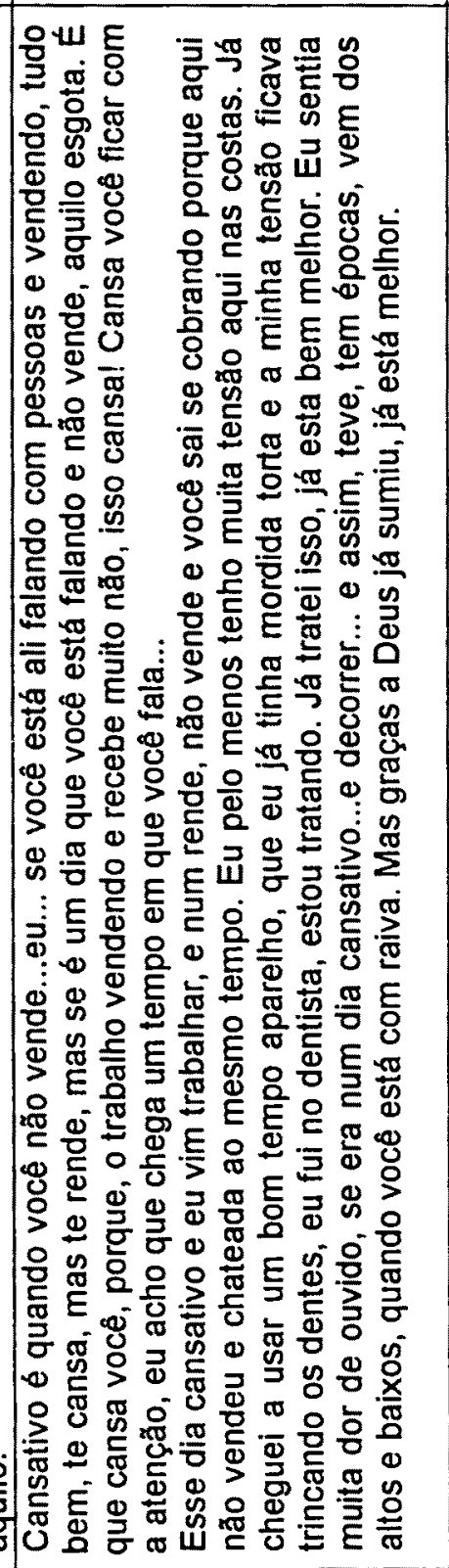 & & \\
\hline 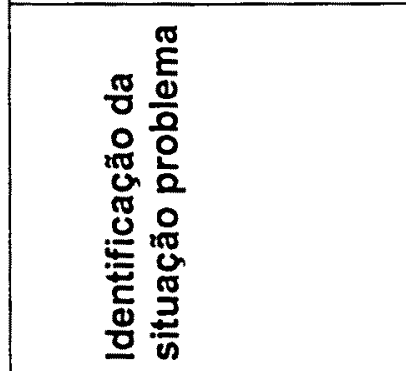 & 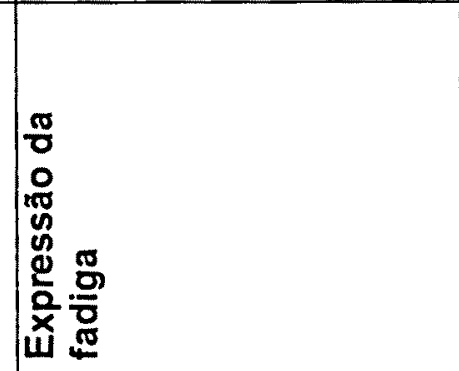 & 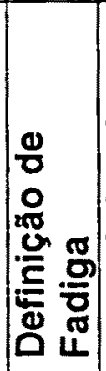 & 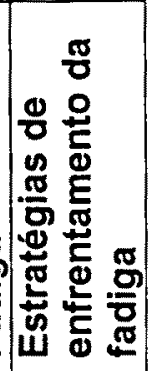 \\
\hline
\end{tabular}




\begin{tabular}{|c|c|c|c|c|}
\hline 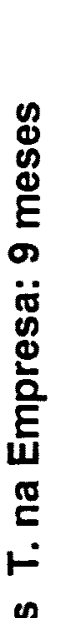 & 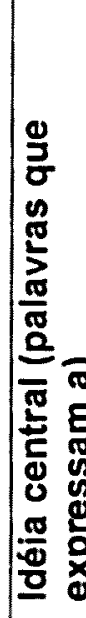 & 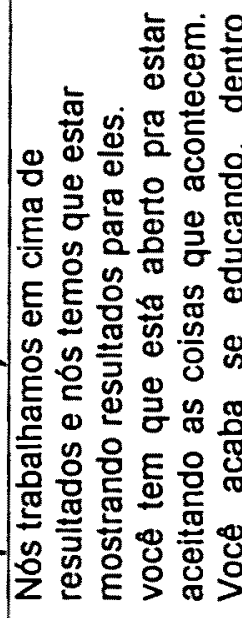 & 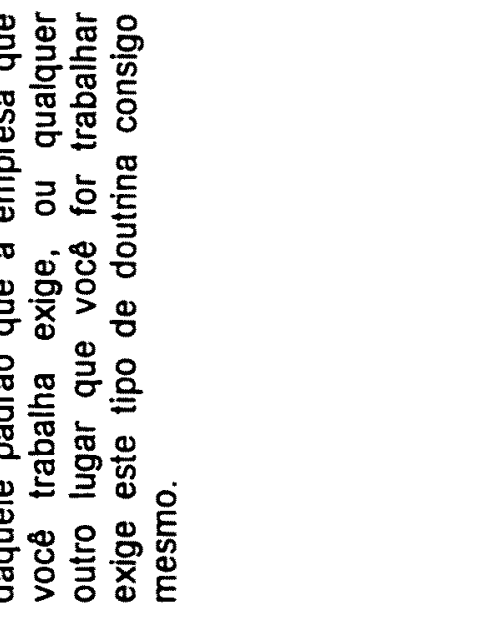 & 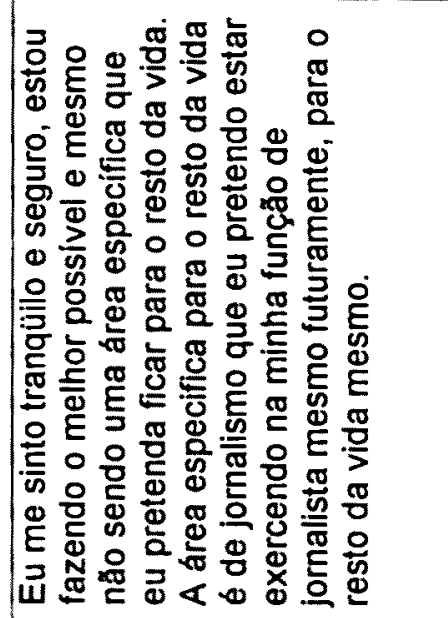 \\
\hline 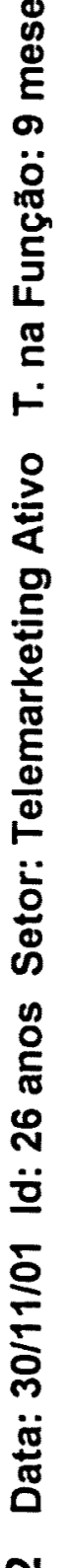 & 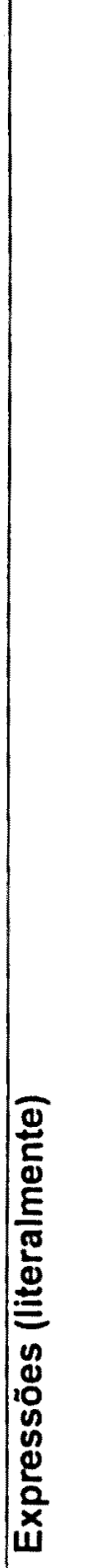 & 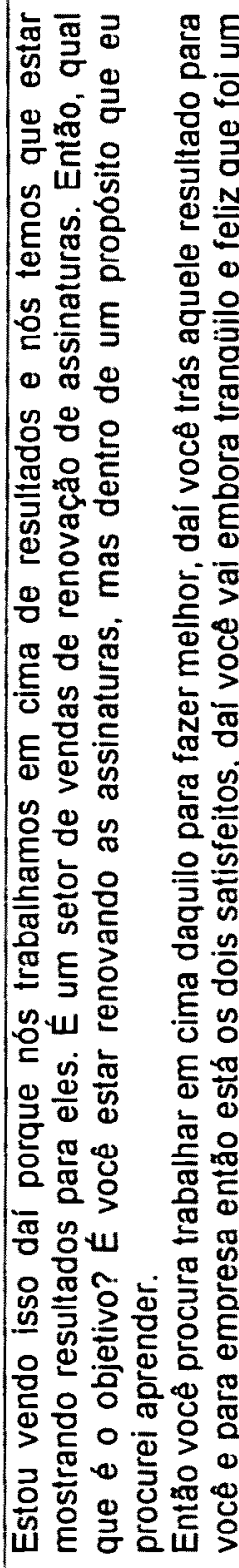 & 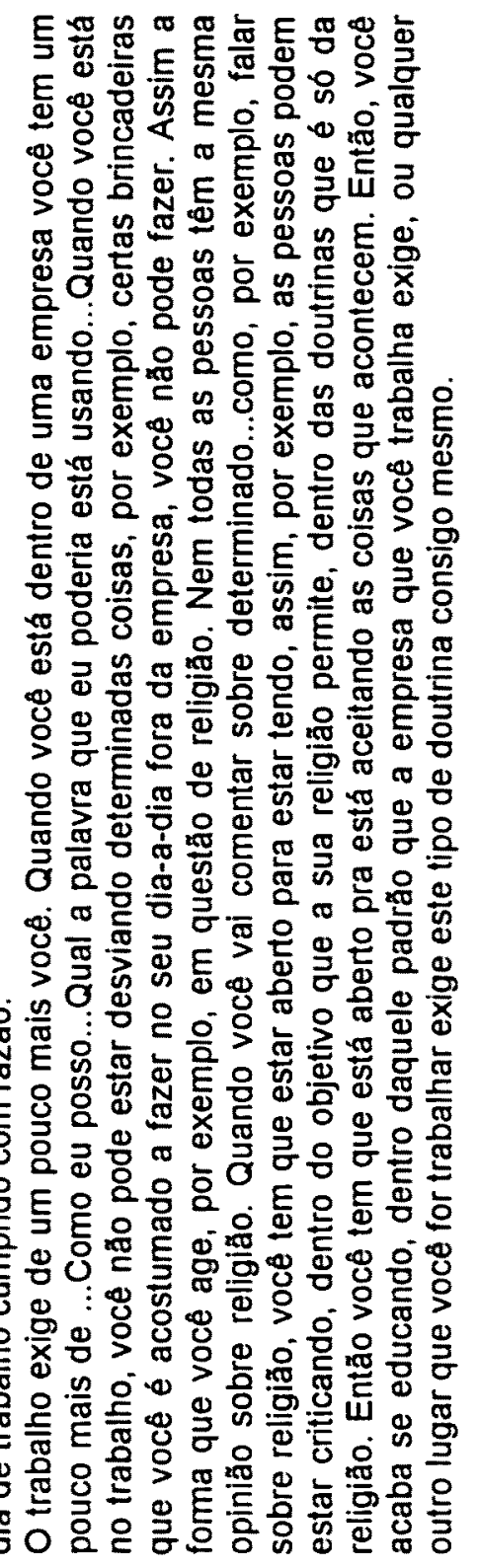 & 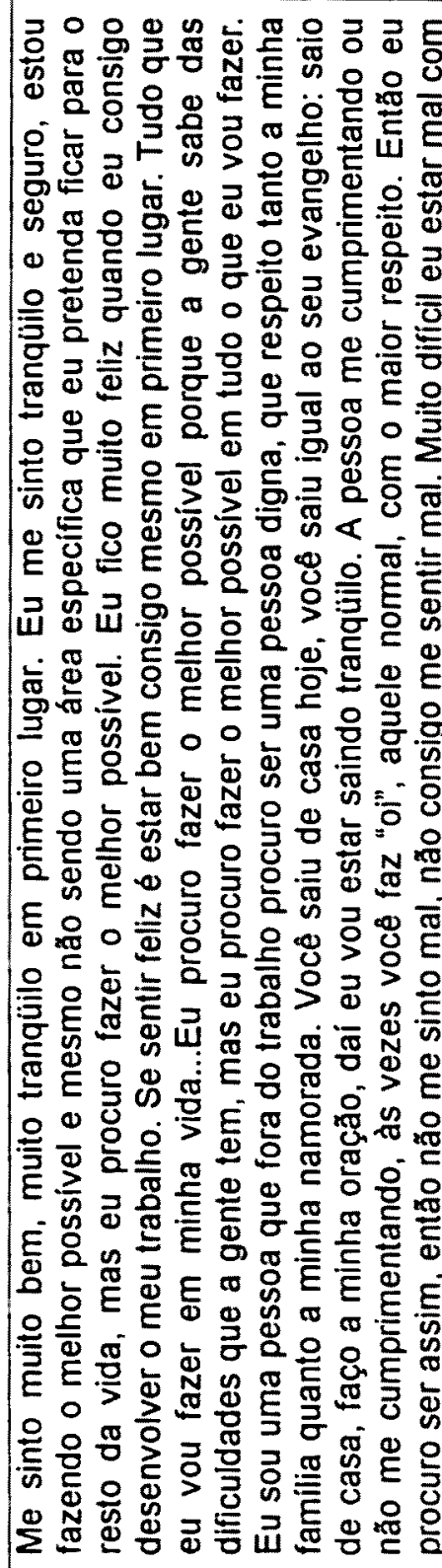 \\
\hline 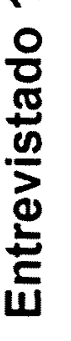 & 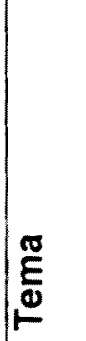 & 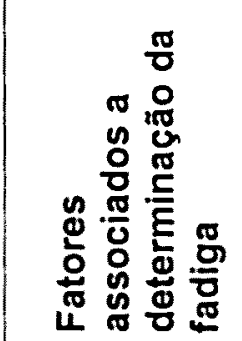 & & 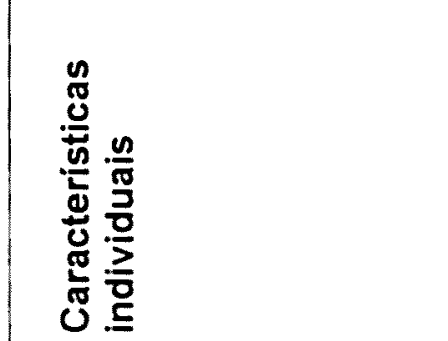 \\
\hline
\end{tabular}




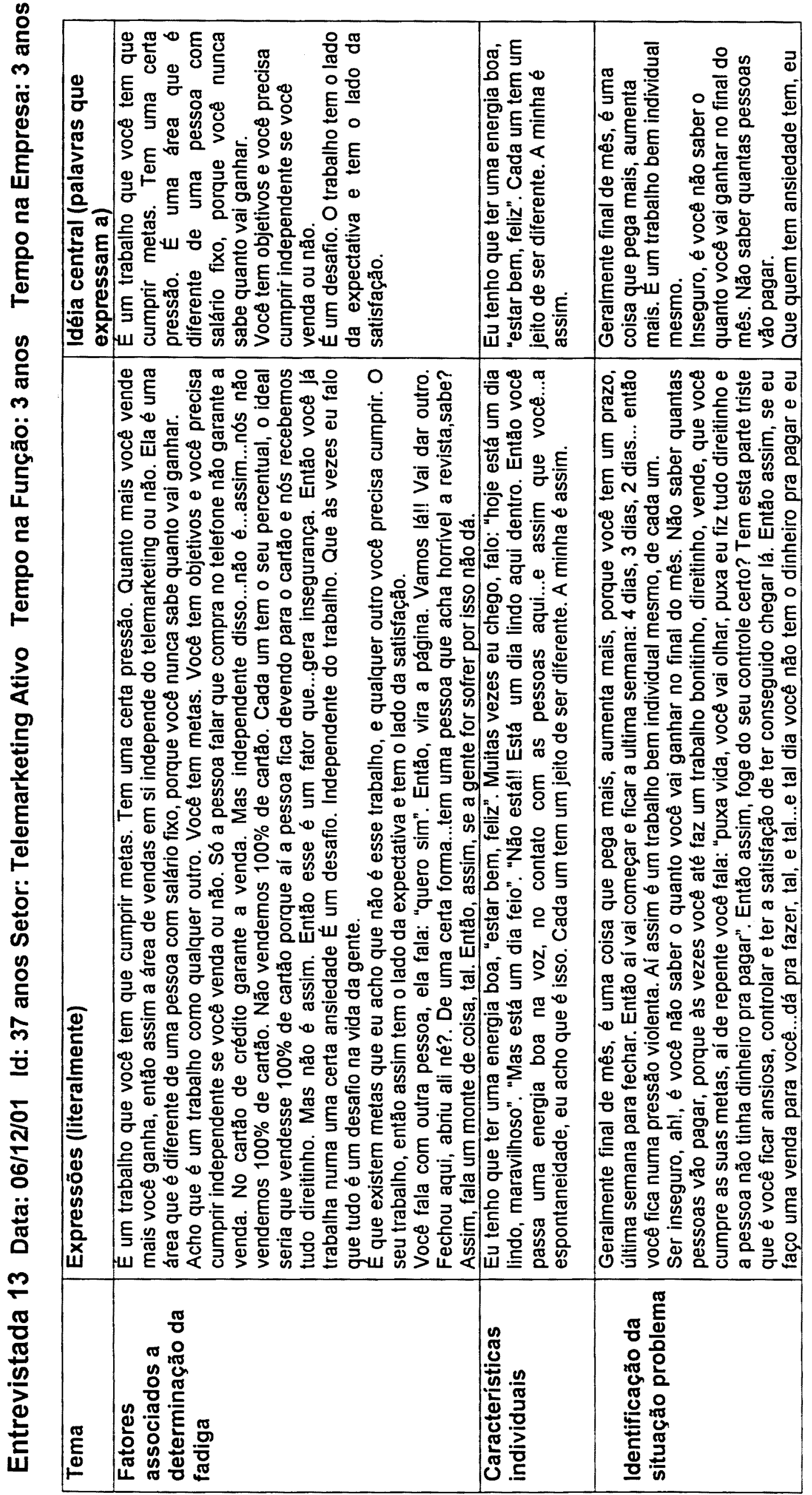




\begin{tabular}{|c|c|c|}
\hline 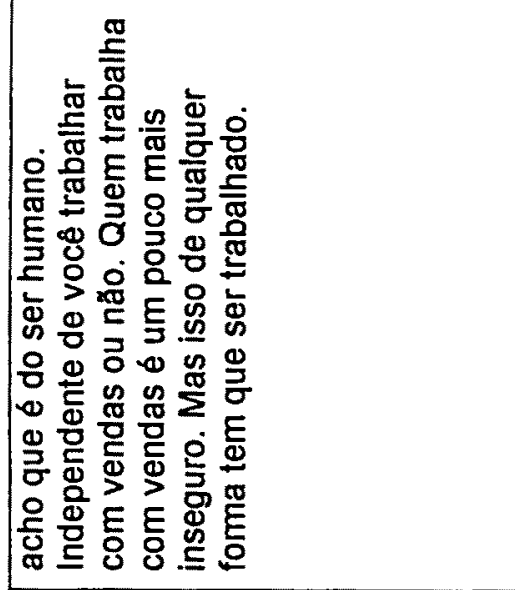 & & 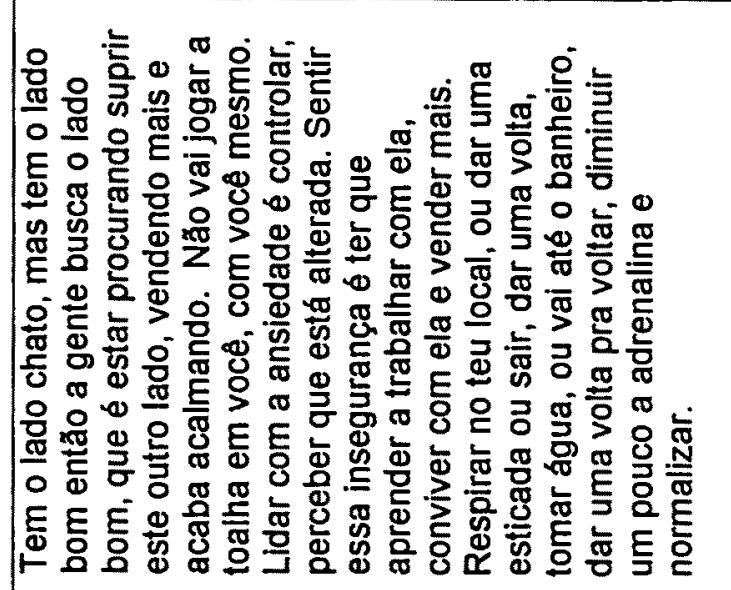 \\
\hline 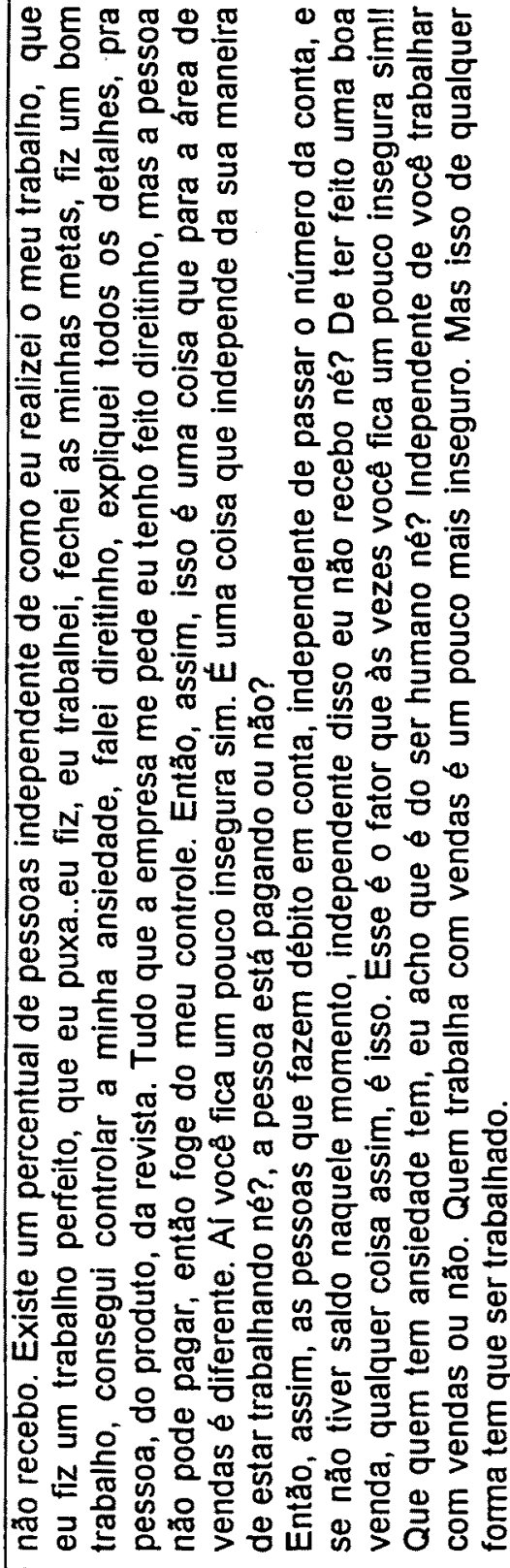 & & 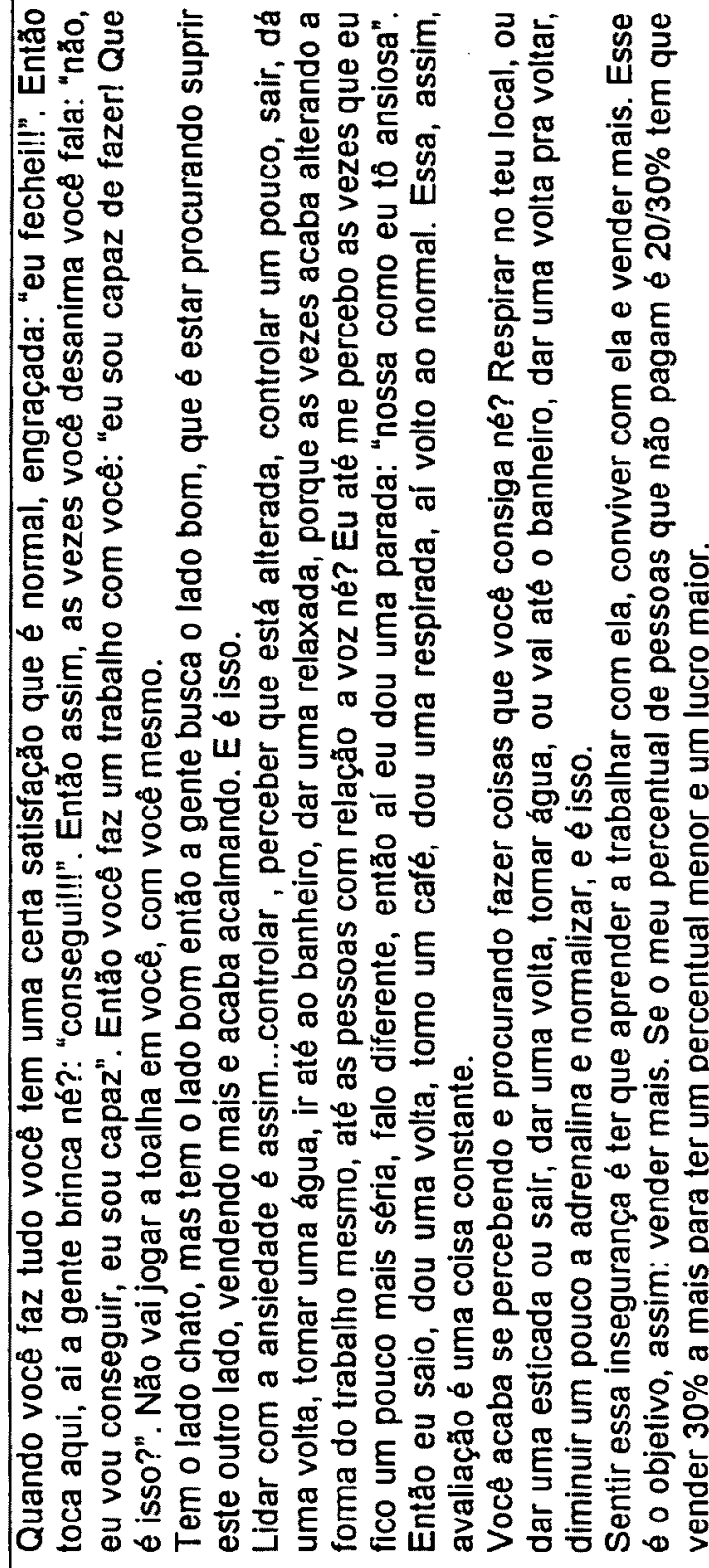 \\
\hline 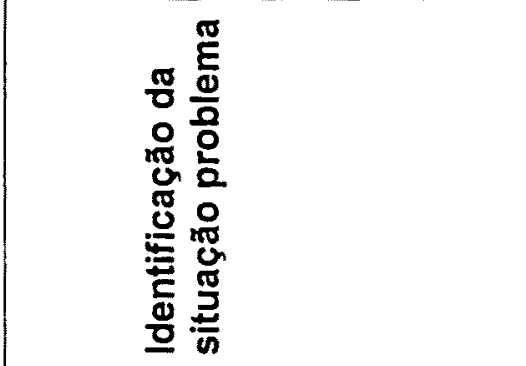 & 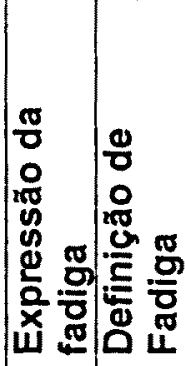 & 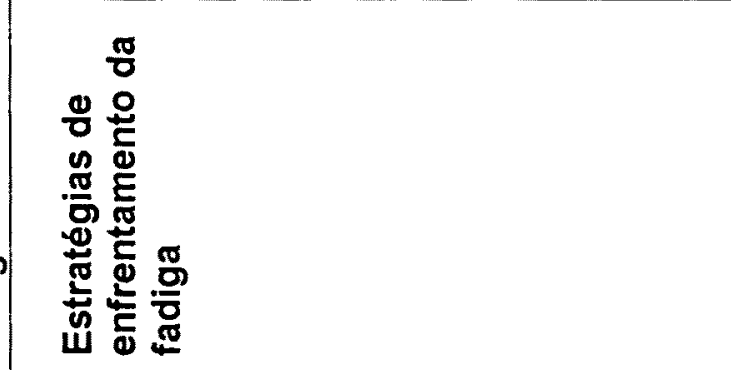 \\
\hline
\end{tabular}


n

\begin{tabular}{|c|c|c|c|c|c|}
\hline 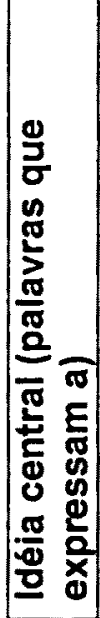 & 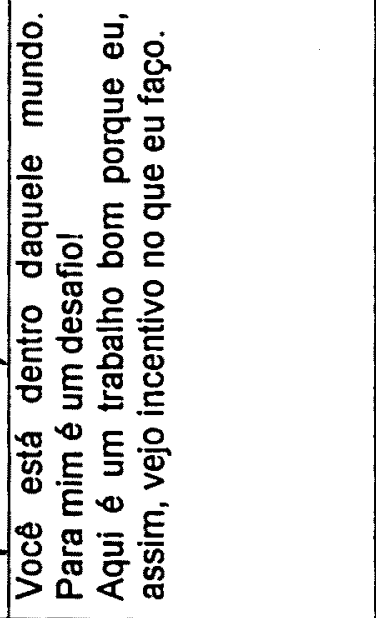 & 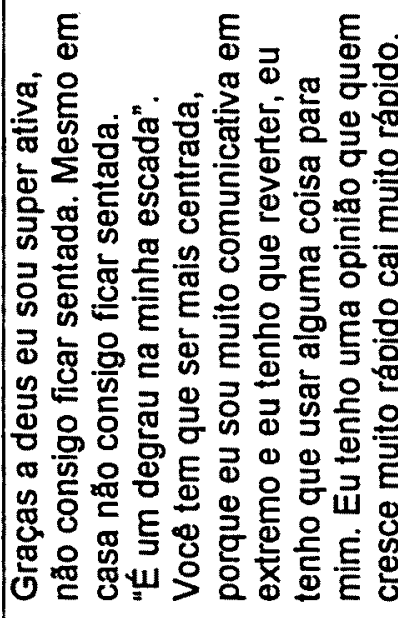 & 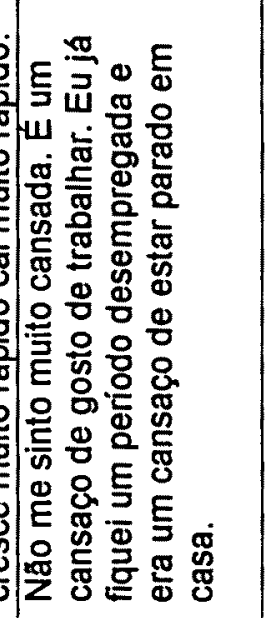 & & \\
\hline 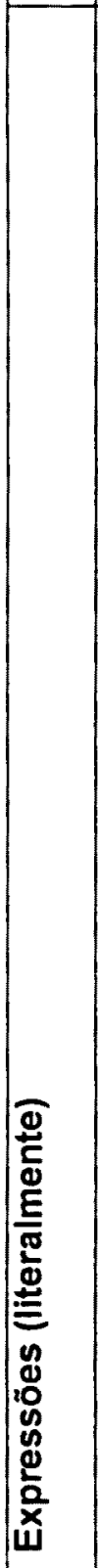 & 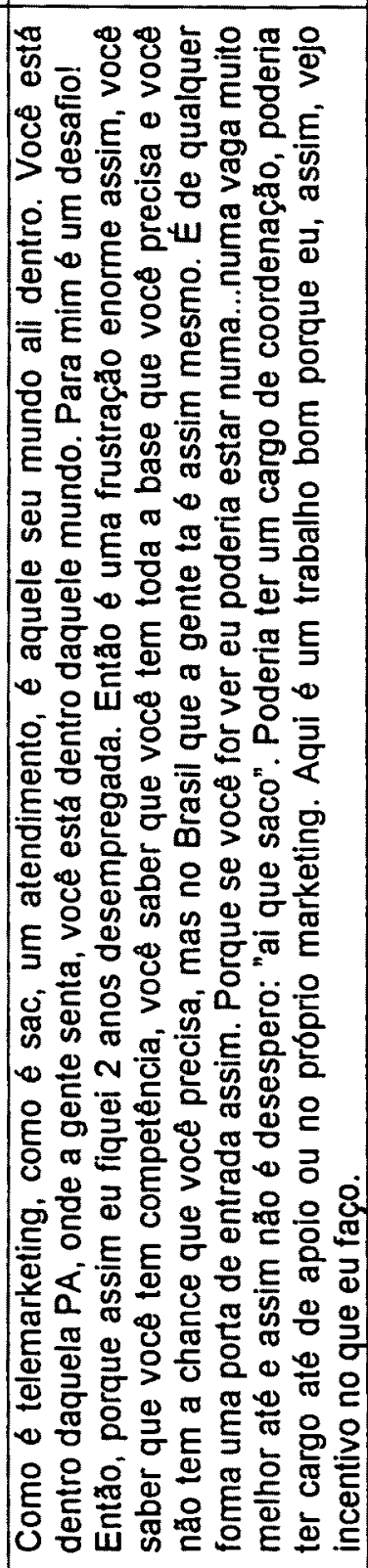 & 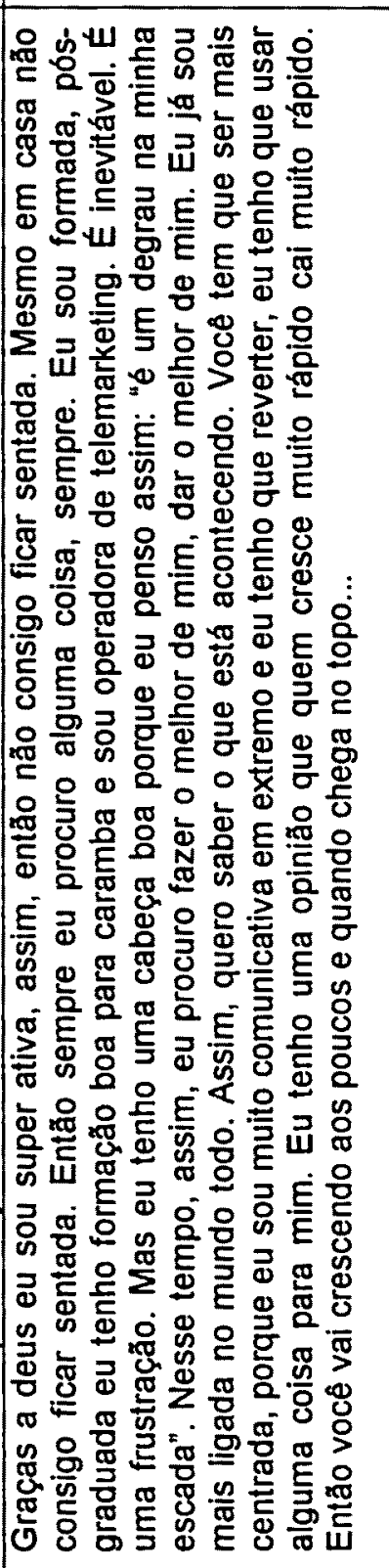 & 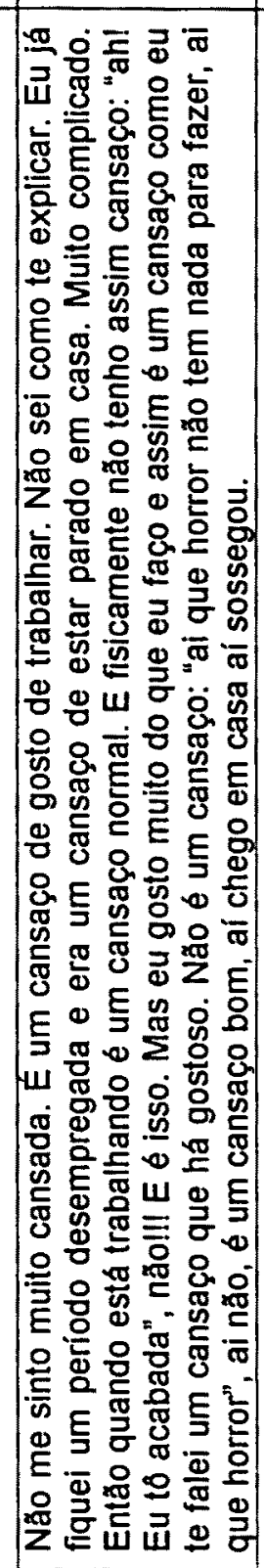 & & \\
\hline $\mid \underset{\mathbb{E}}{\stackrel{\Xi}{\Xi}}$ & 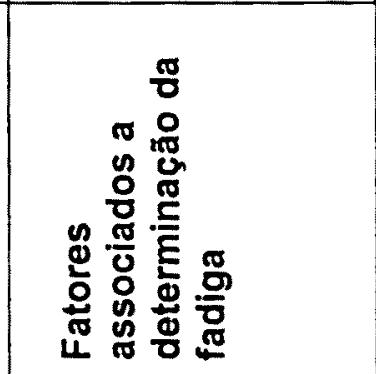 & 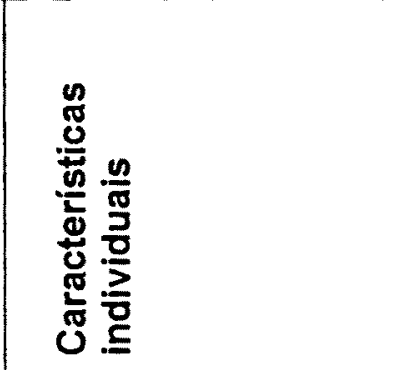 & 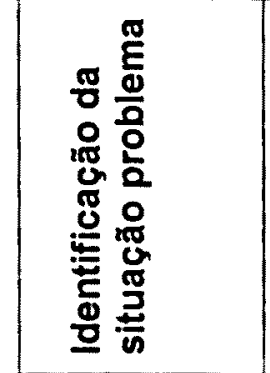 & 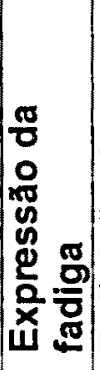 & 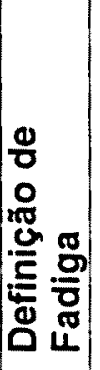 \\
\hline
\end{tabular}




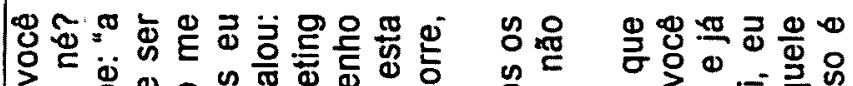
等

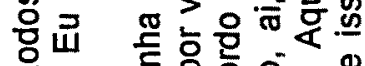
N

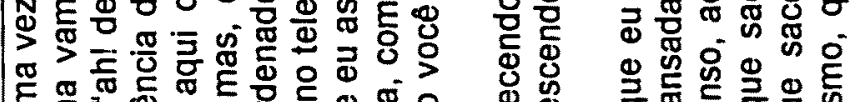

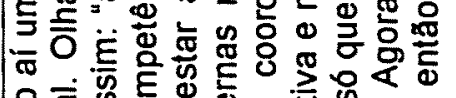
政

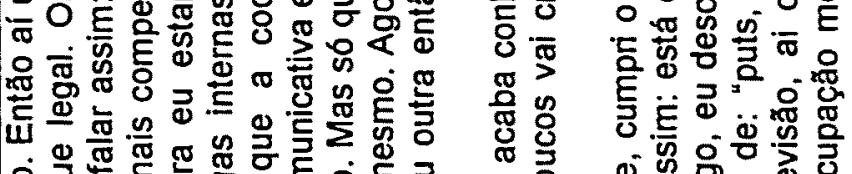

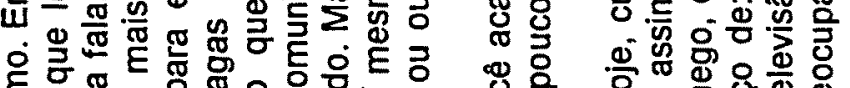

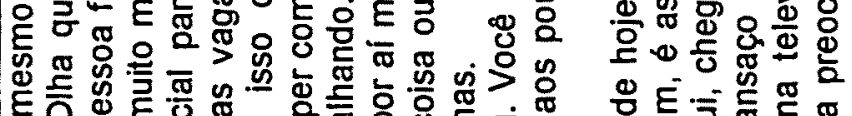

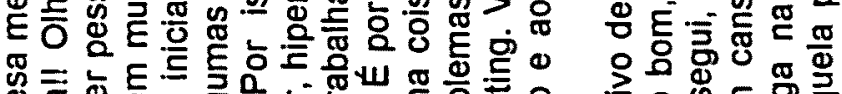

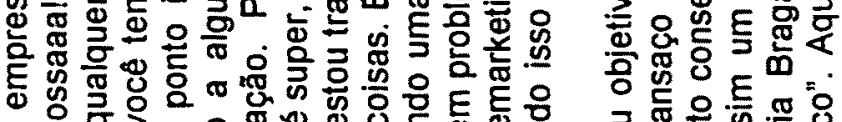
ه đั

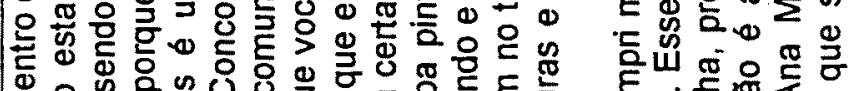

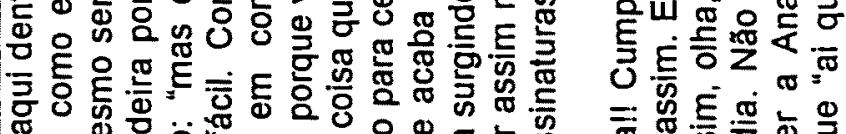

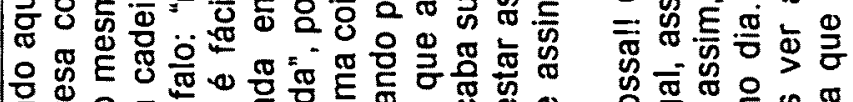

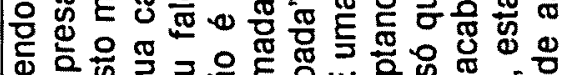
递

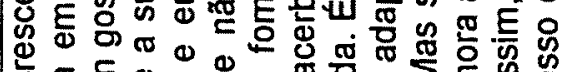

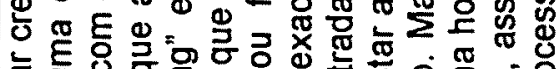

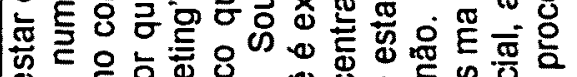

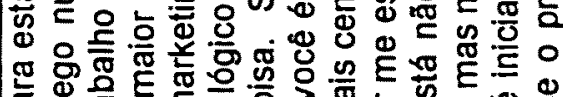

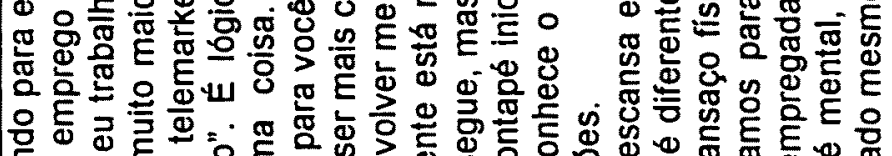

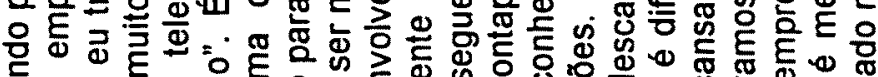

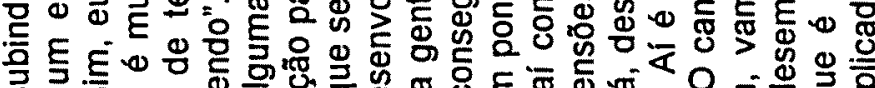
品

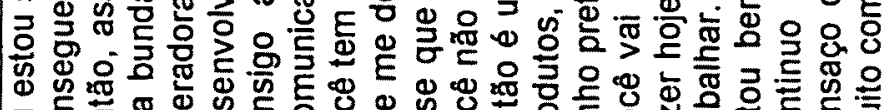

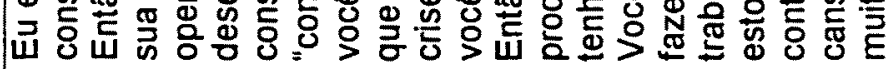

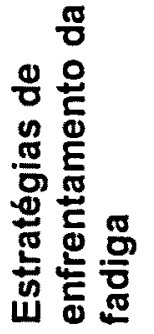




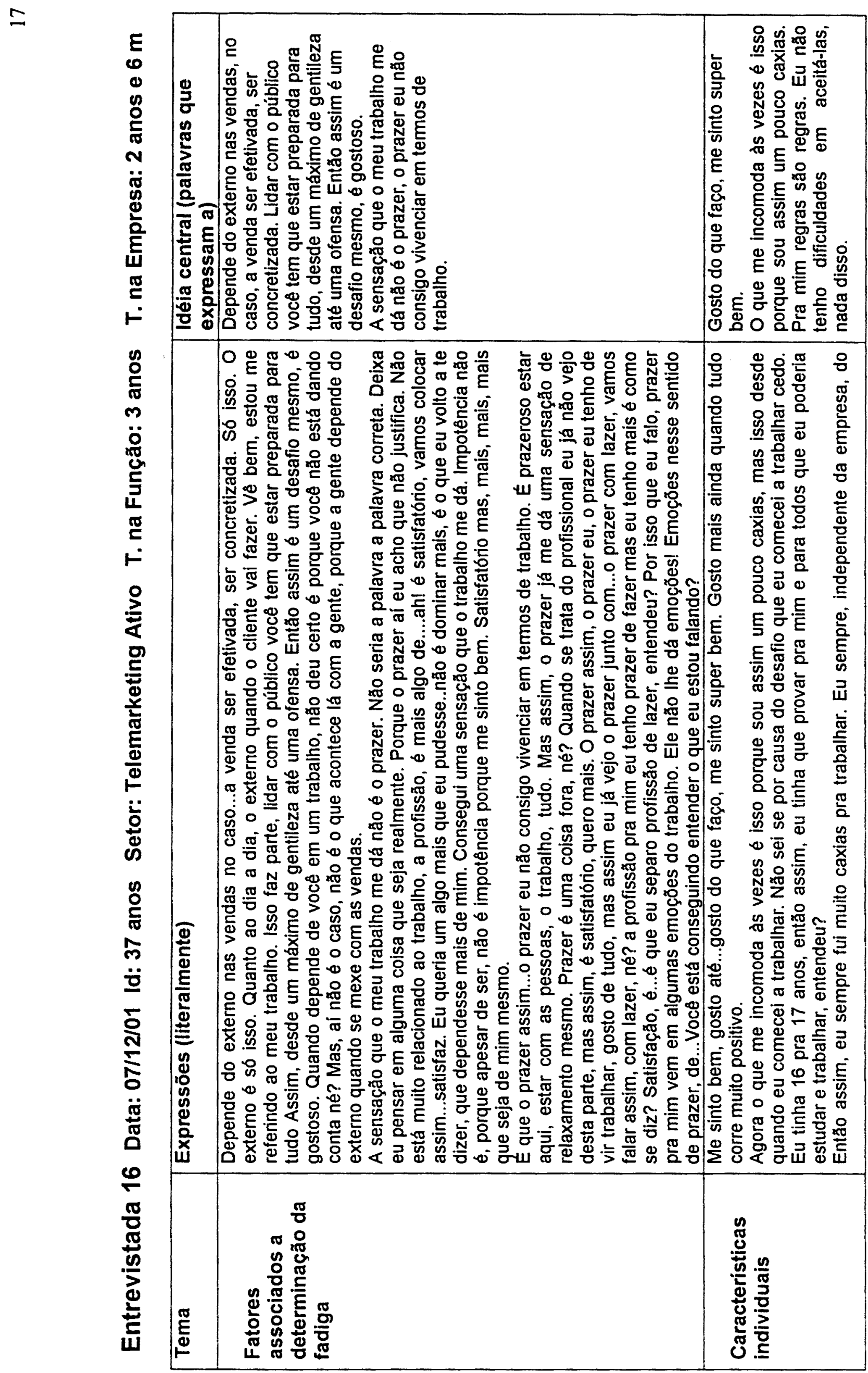




\begin{tabular}{|c|c|c|c|c|}
\hline & 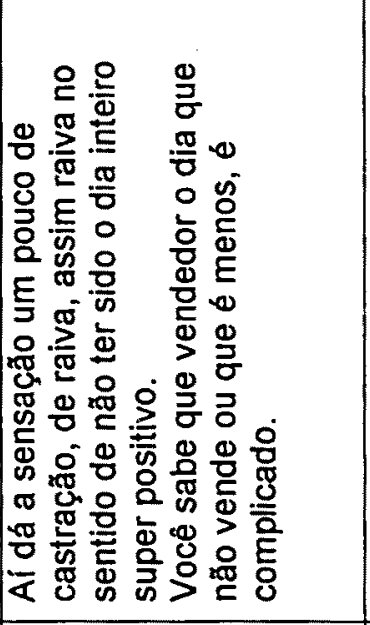 & & & 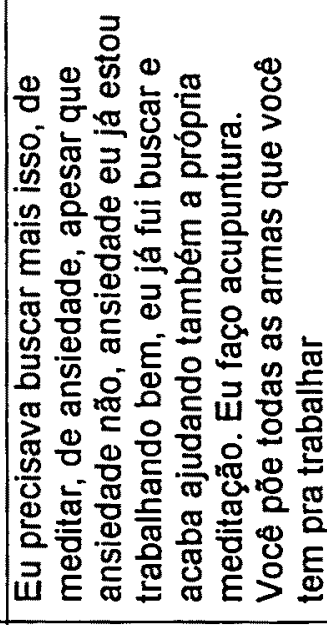 \\
\hline 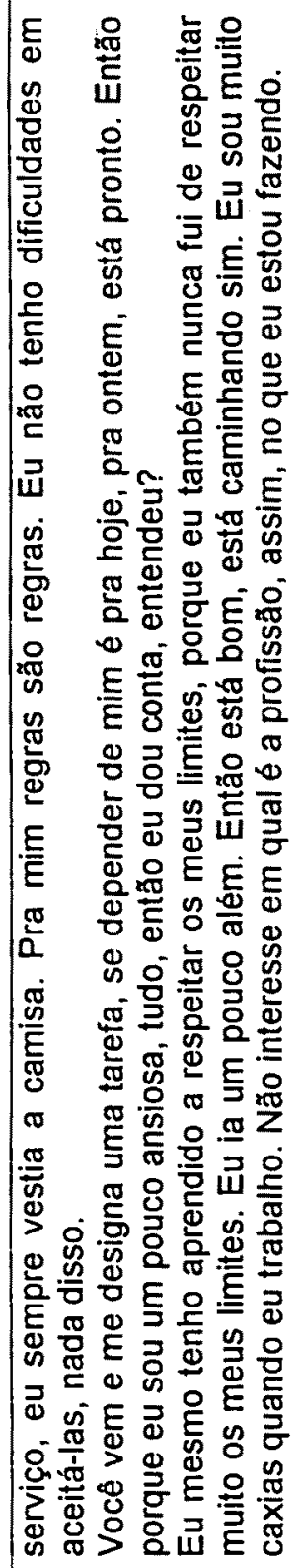 & 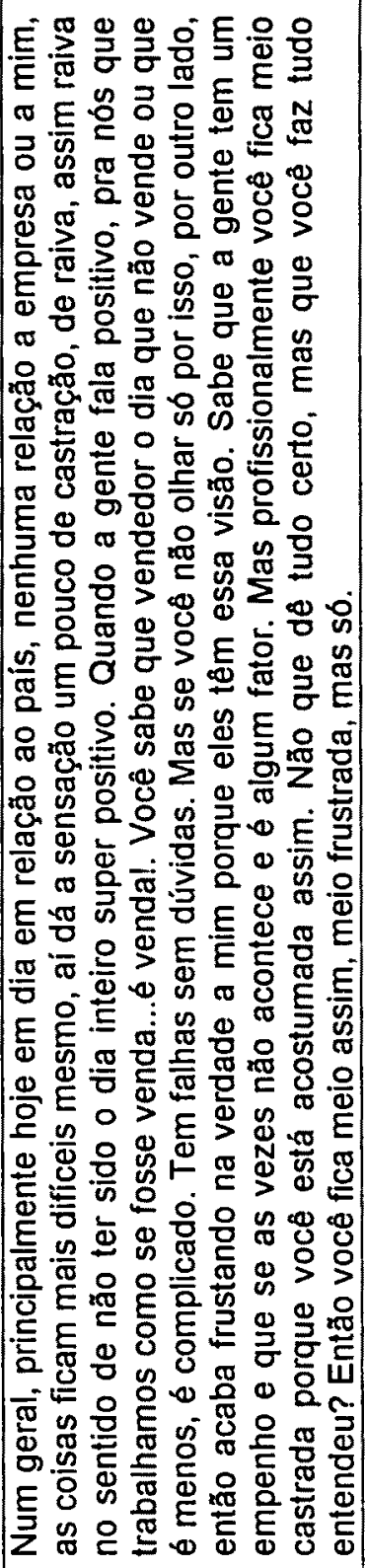 & & & 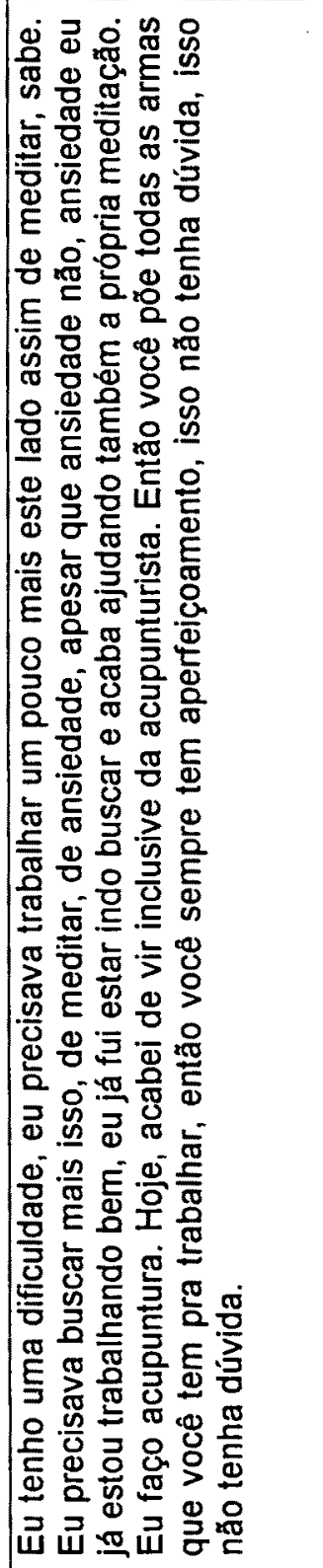 \\
\hline 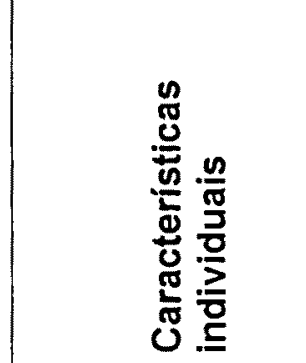 & 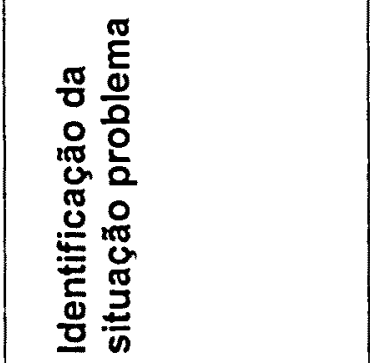 & 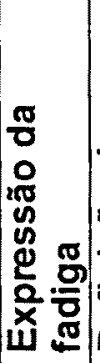 & 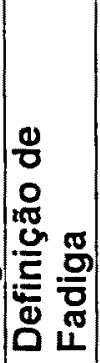 & 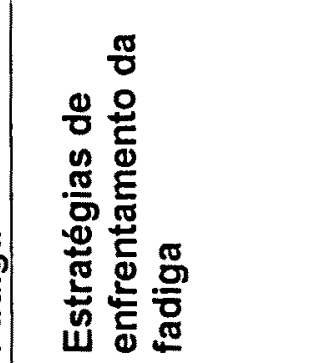 \\
\hline
\end{tabular}




\begin{tabular}{|c|c|c|c|c|c|}
\hline 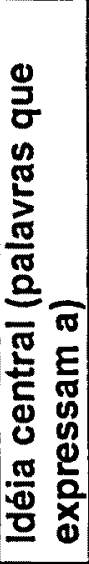 & 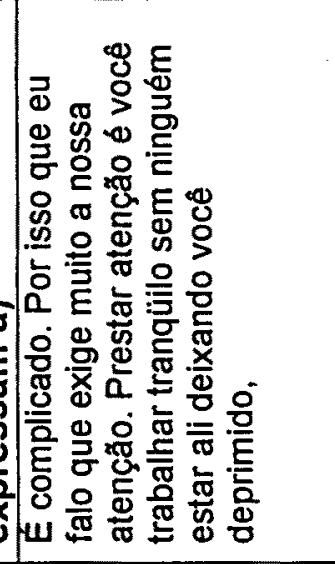 & 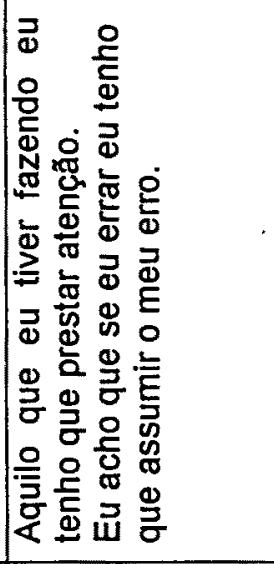 & & & 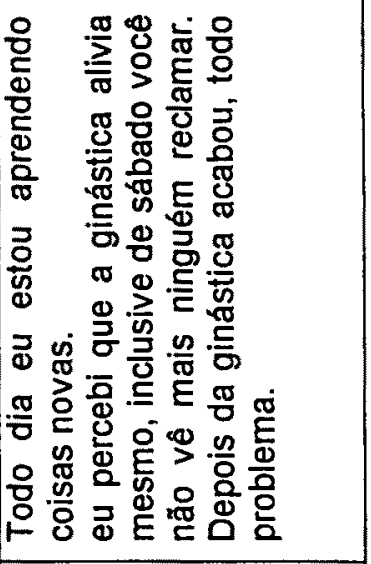 \\
\hline 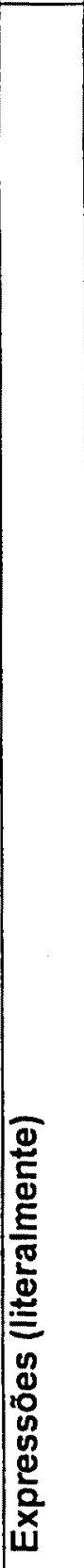 & 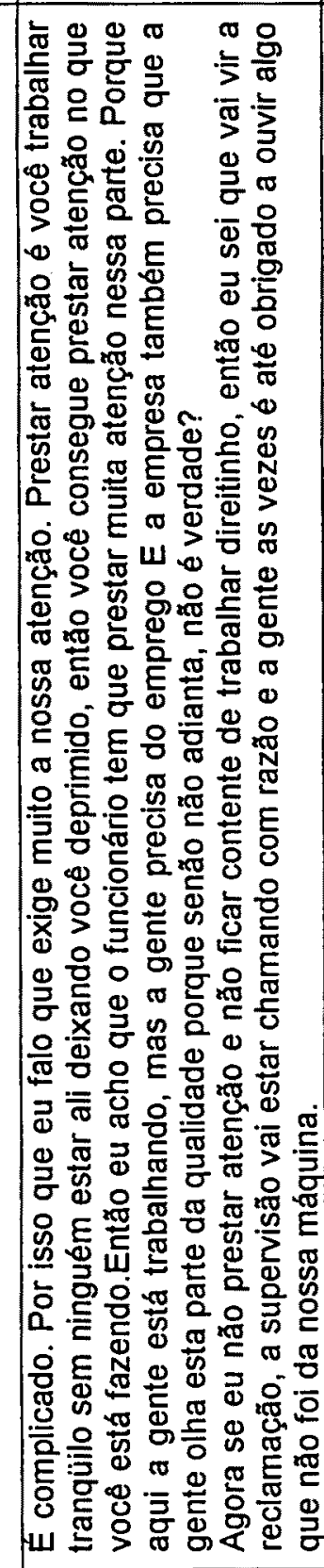 & 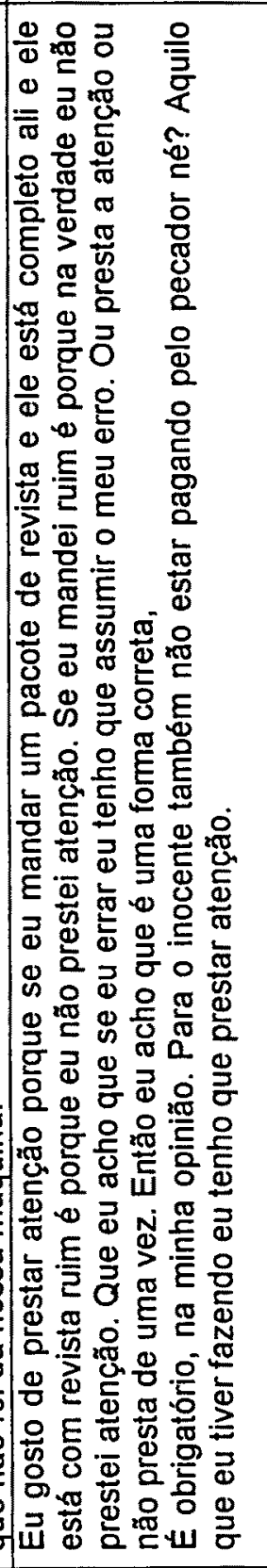 & & & 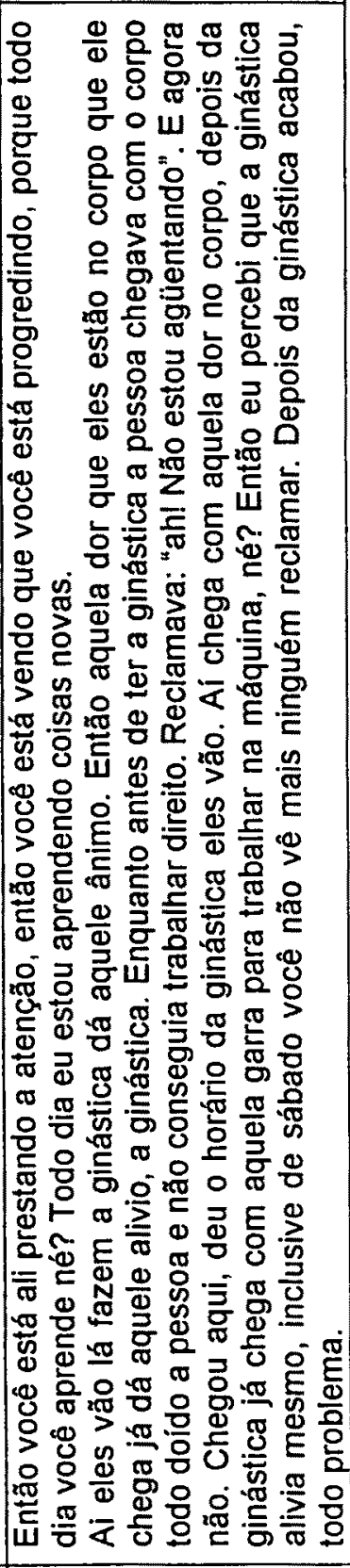 \\
\hline 莺 & 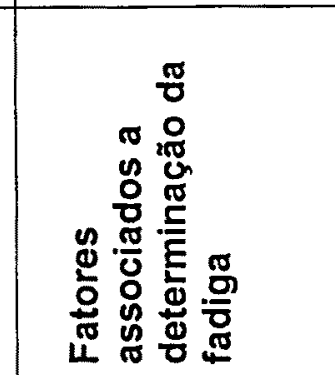 & 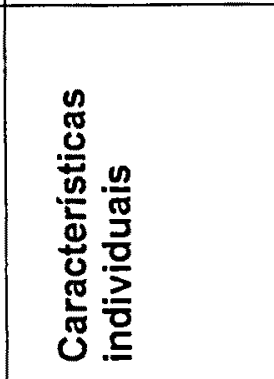 & 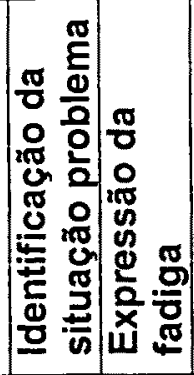 & 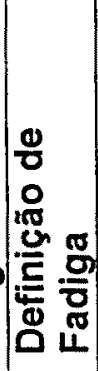 & 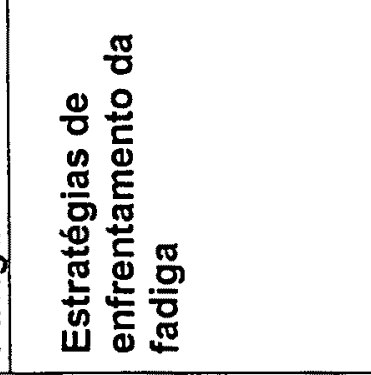 \\
\hline
\end{tabular}


우

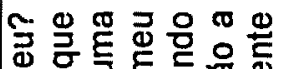

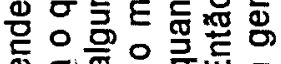

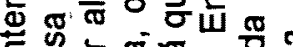

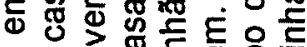
E E 융

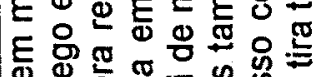

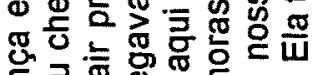

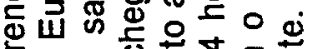

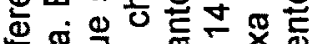

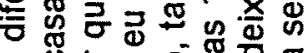
올 이유 >눙 Ј

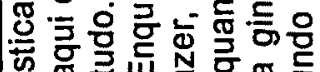

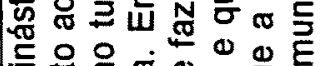

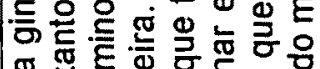
๘

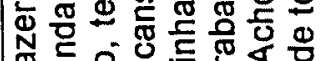

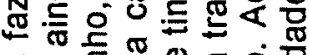

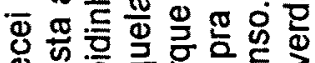

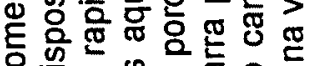
엉 ప $\frac{\mathscr{D}}{\mathrm{E}}$ ह

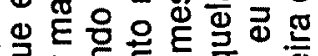

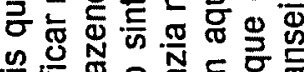
느ㅇㅠㅠ

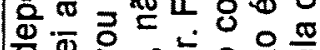
导

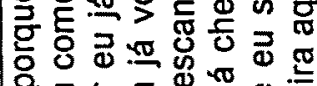

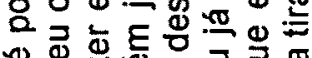
؛

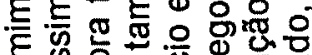

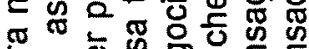

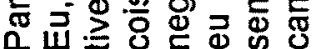

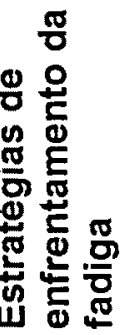




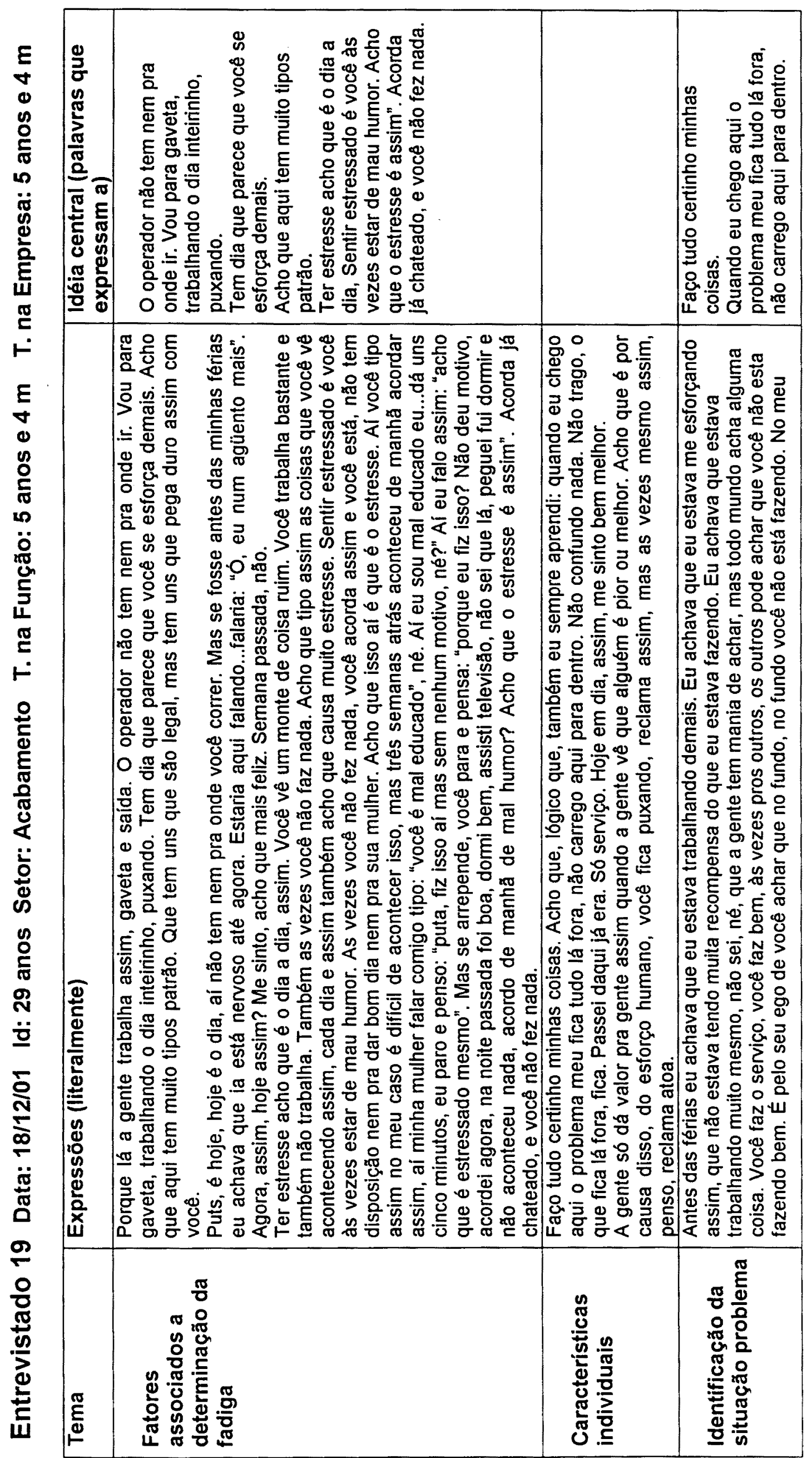




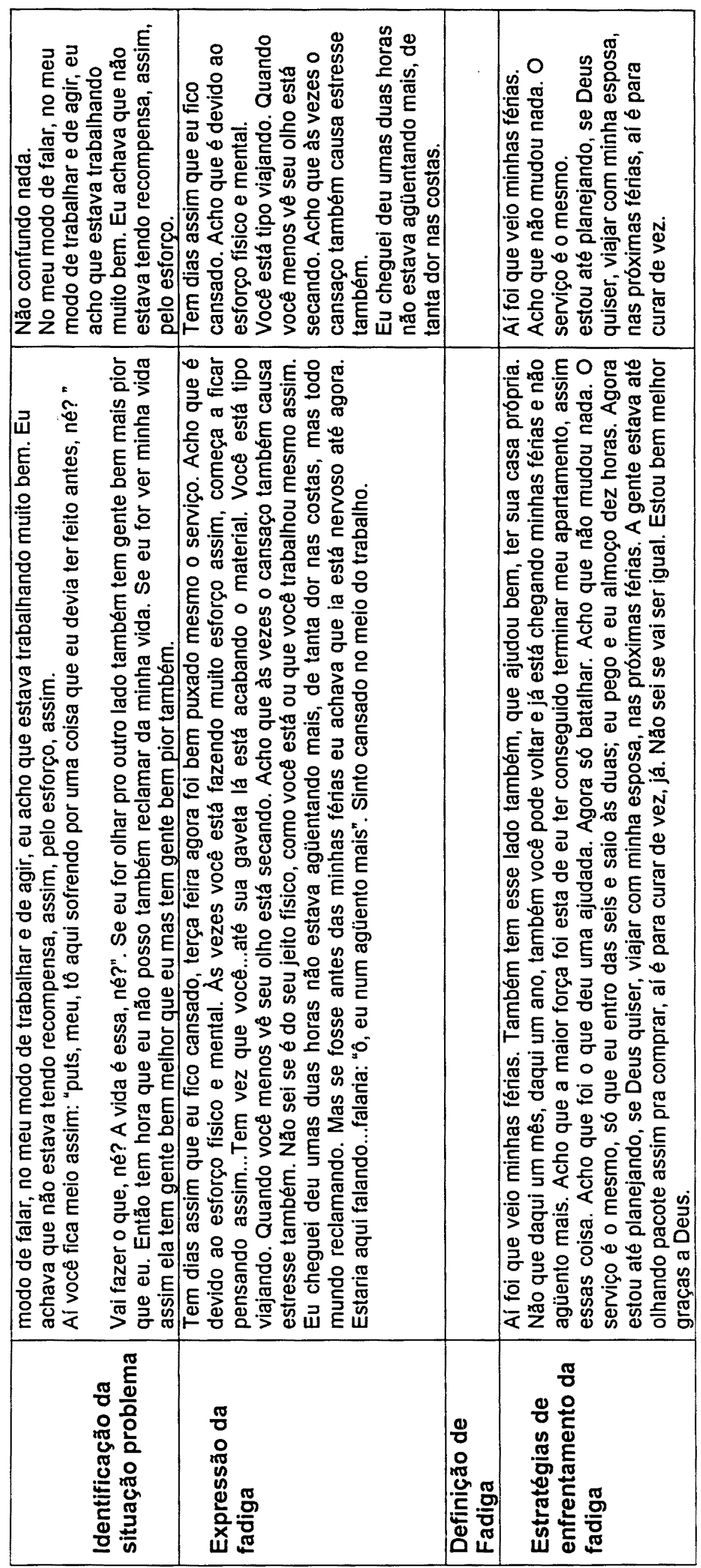




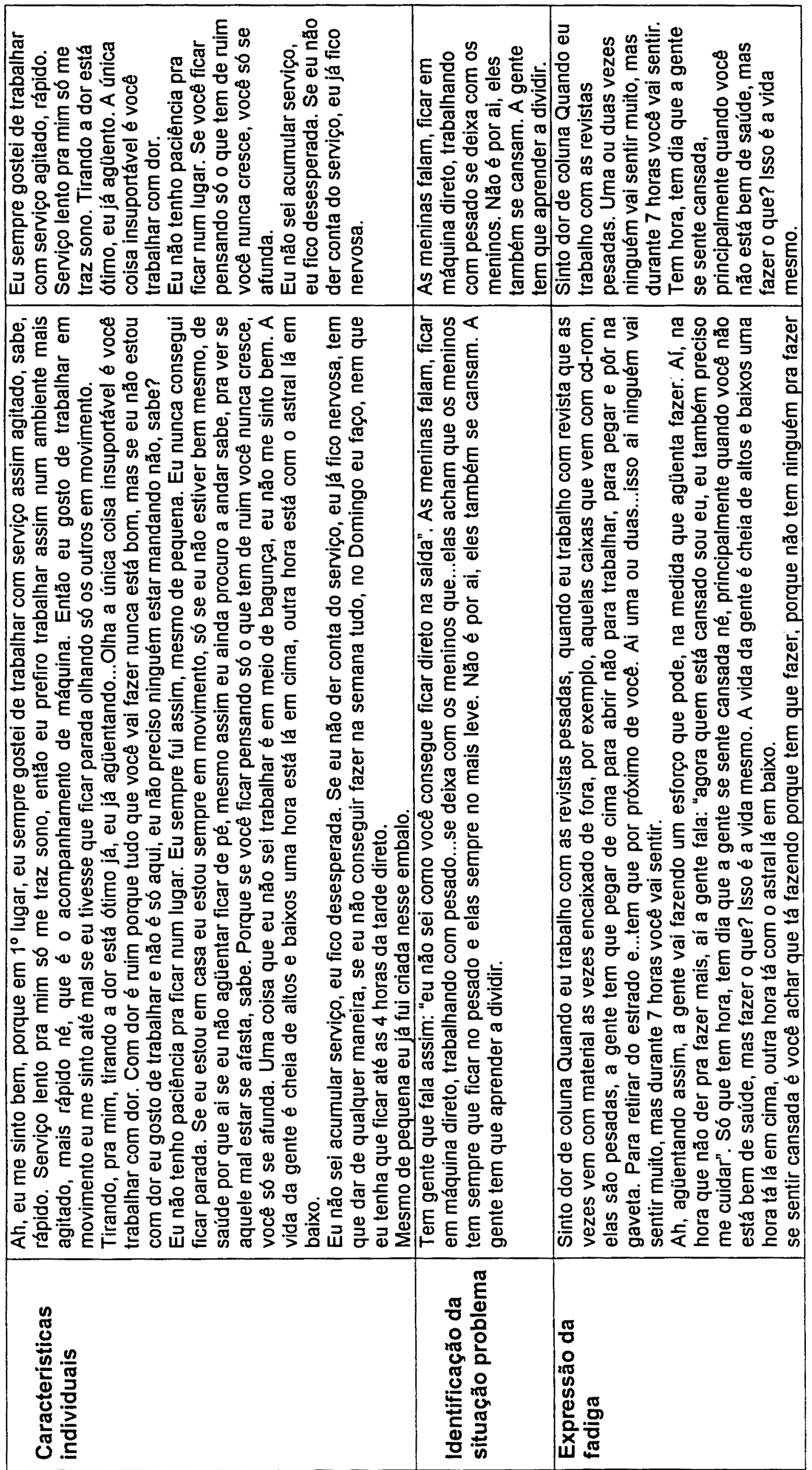




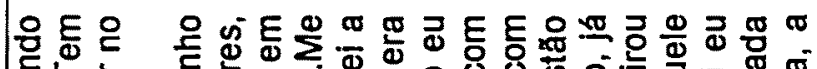

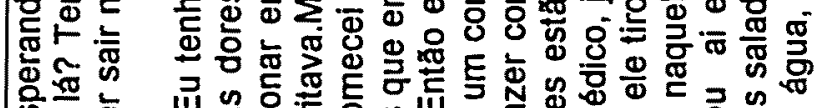

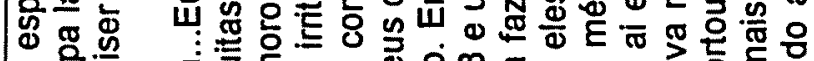
응 \%

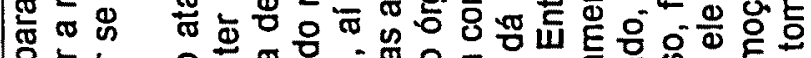

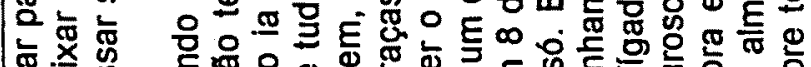

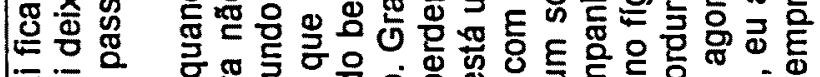

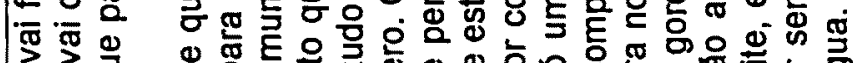

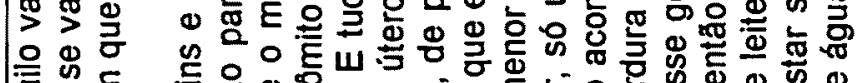
窵出 总出 은

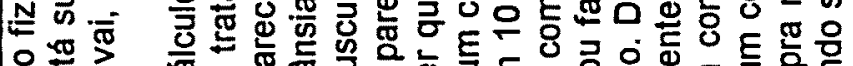

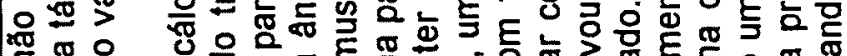
舟

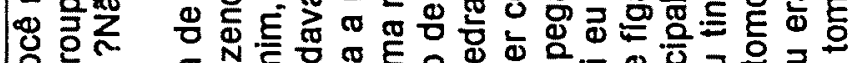
>

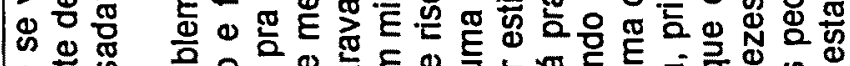

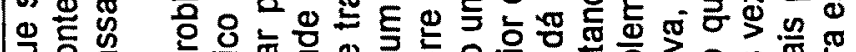

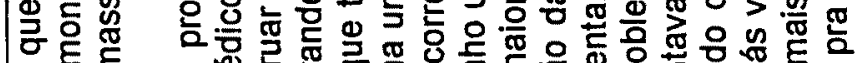

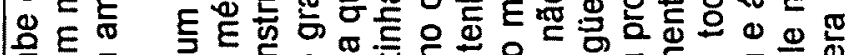
ه

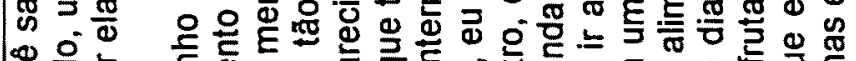

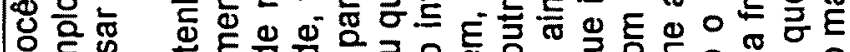

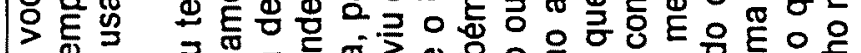

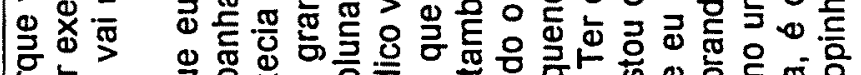

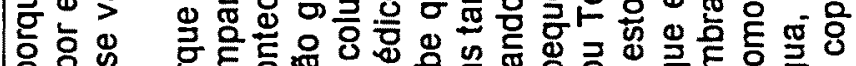

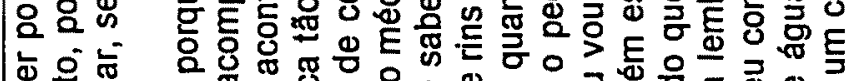
迩选忽

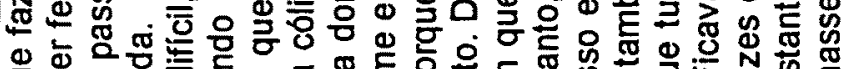

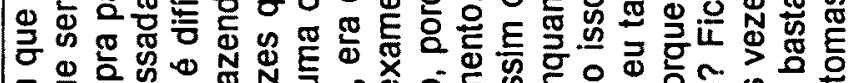

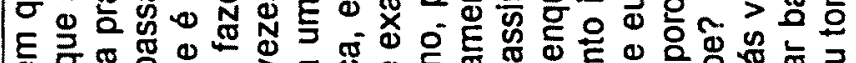
屯 б

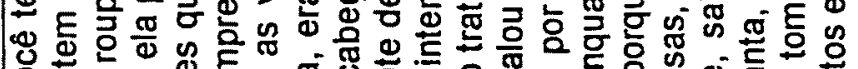

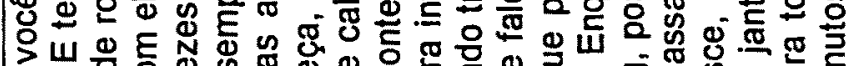

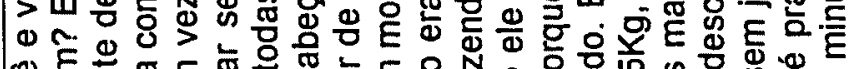
$\circlearrowleft$ E.

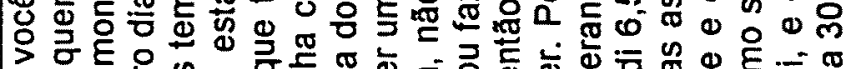
>

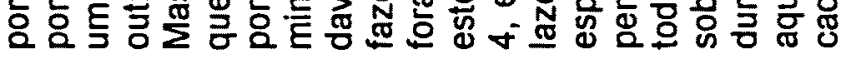

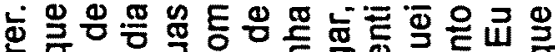

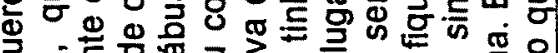

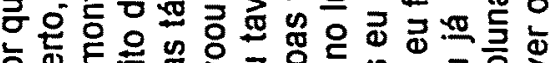
함 뜨 잉

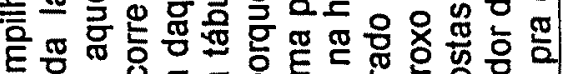

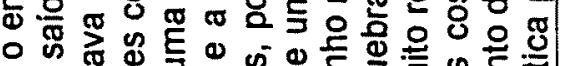
E⿺辶一兀

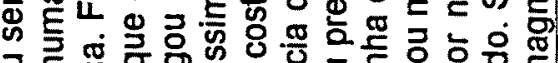
在

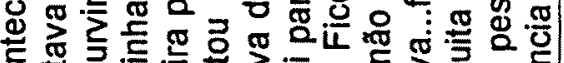

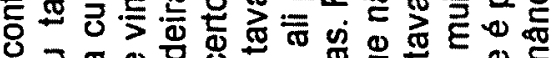
ब

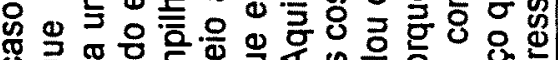

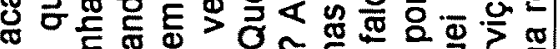

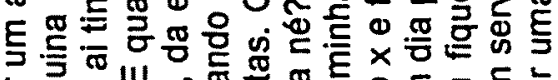

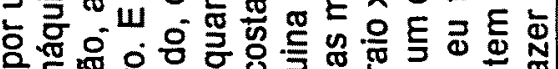

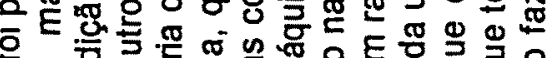
颔

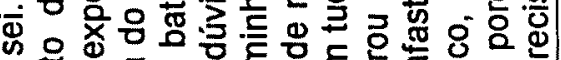
주

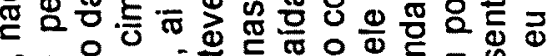

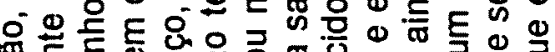

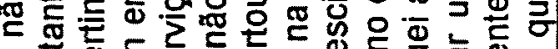

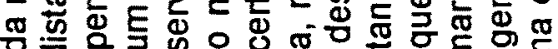
类 ฆ

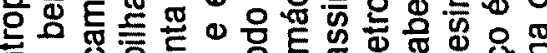

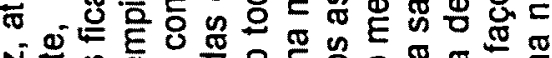
N

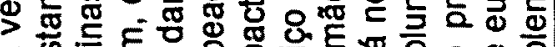

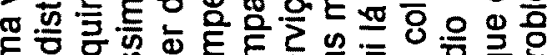
독 要券

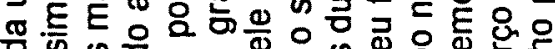

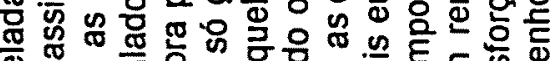
ॠ

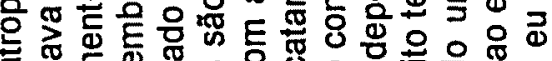

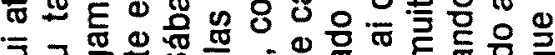

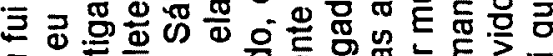
灵此 
i

\begin{tabular}{|c|c|c|}
\hline & & 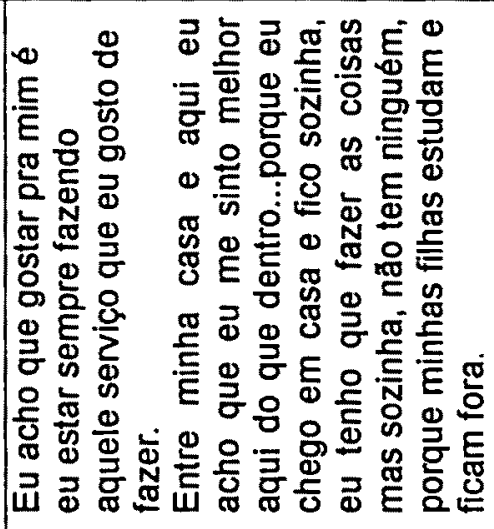 \\
\hline \multirow[t]{2}{*}{ 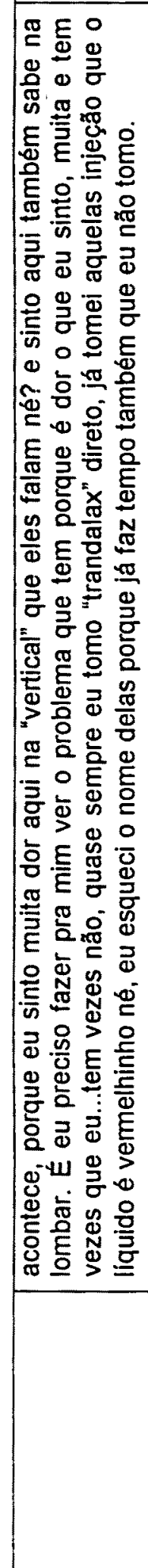 } & & 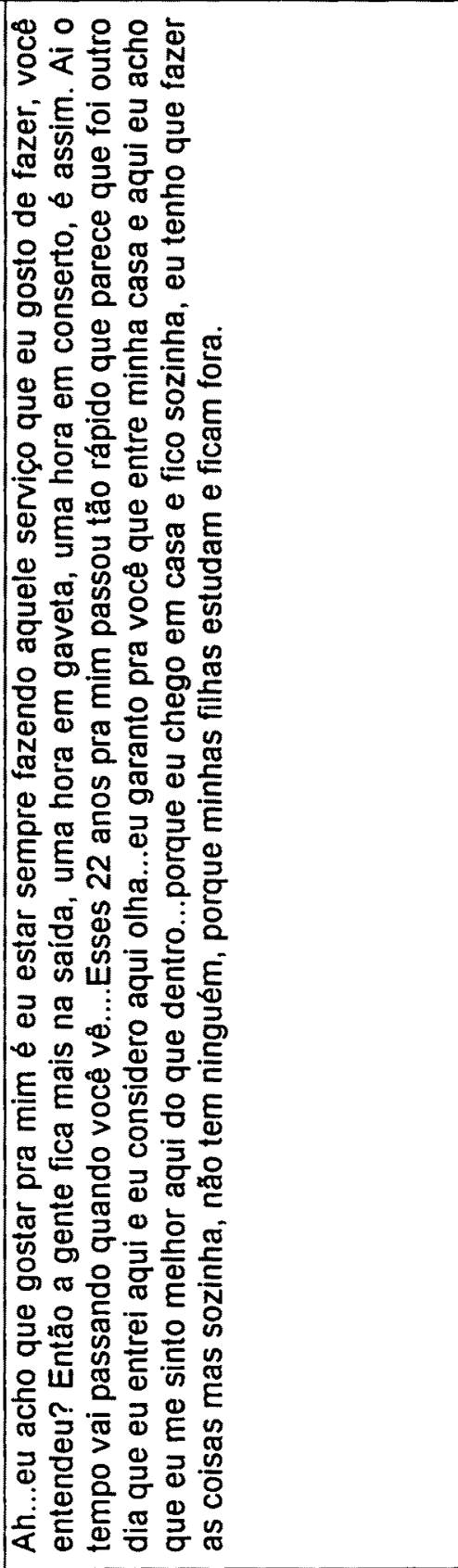 \\
\hline & 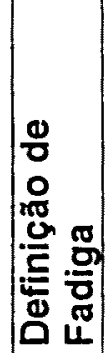 & 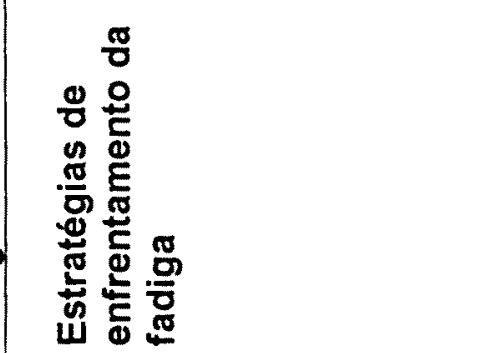 \\
\hline
\end{tabular}




\begin{tabular}{|c|c|c|}
\hline 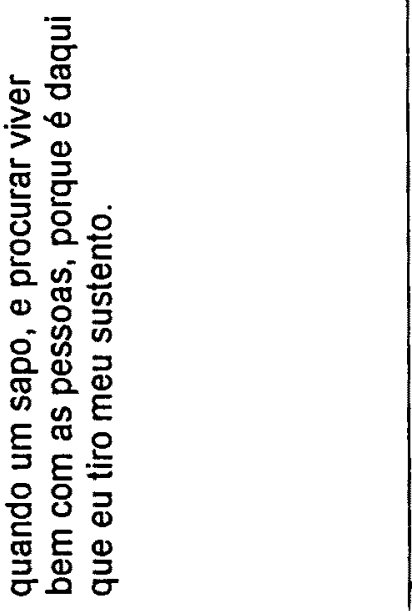 & 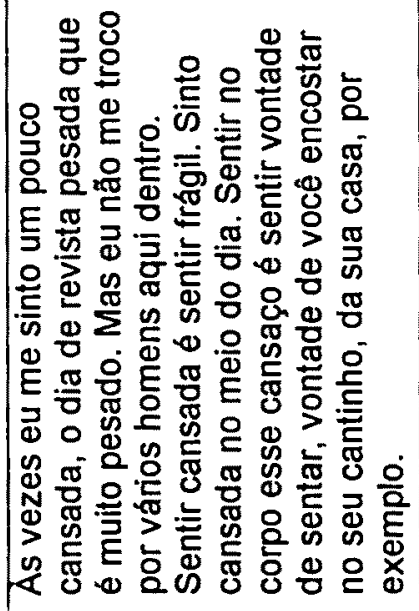 & 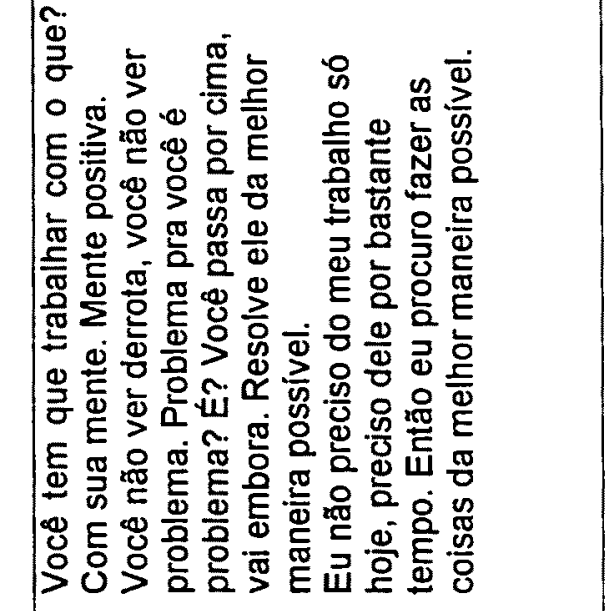 \\
\hline 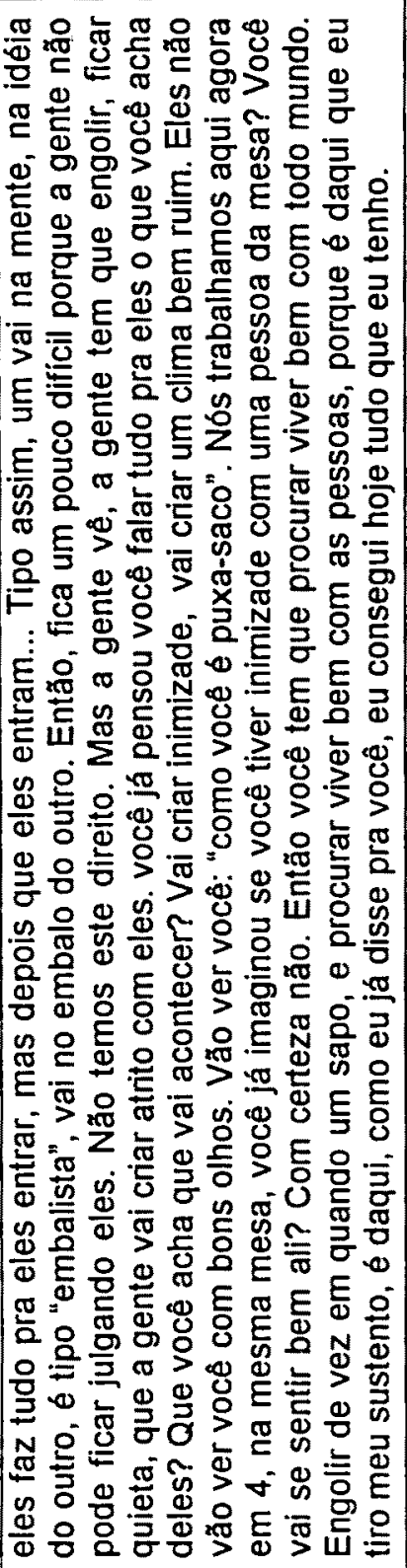 & 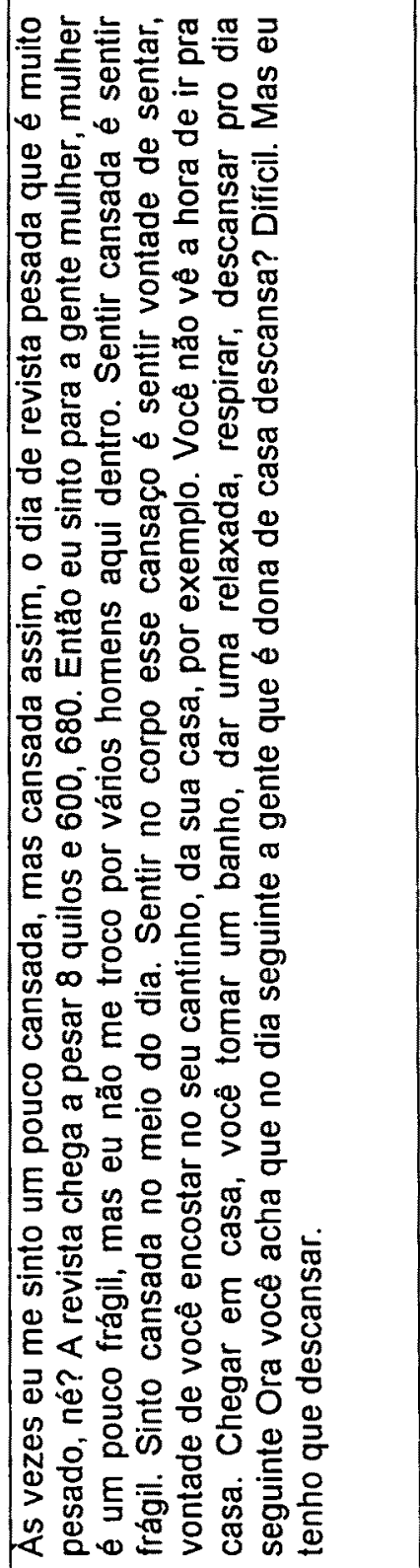 & 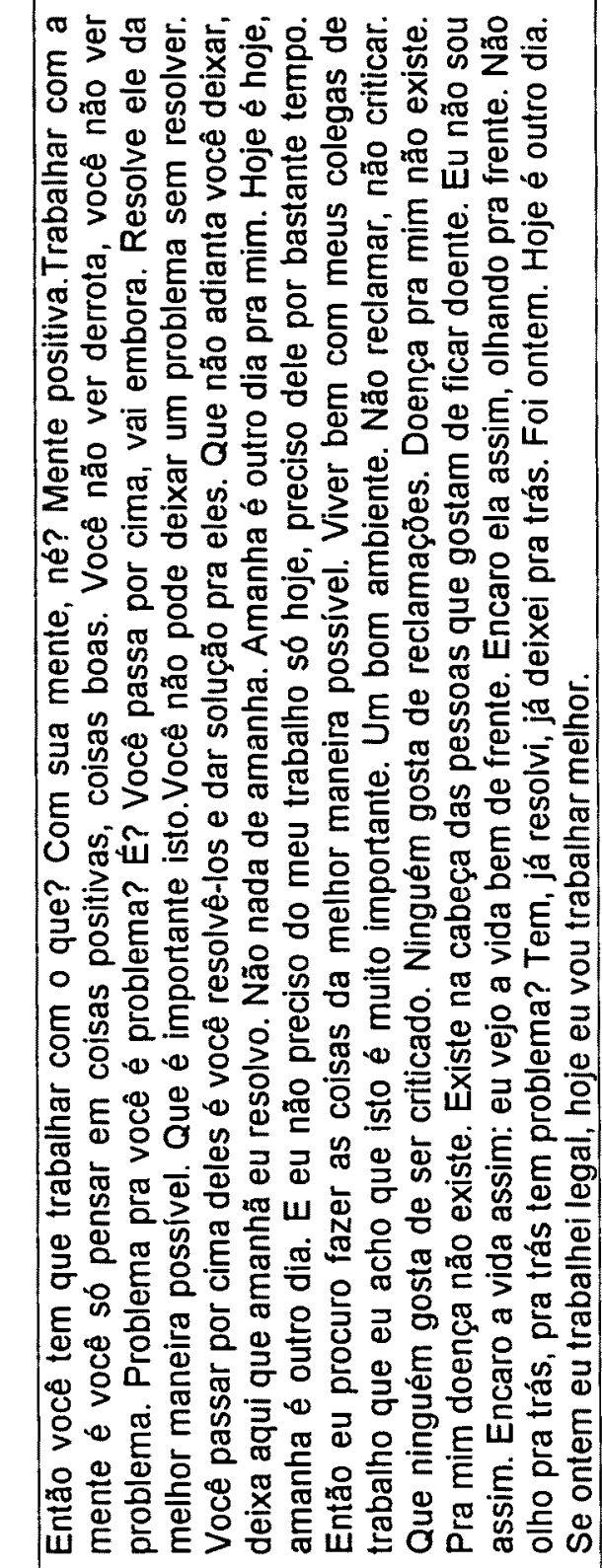 \\
\hline 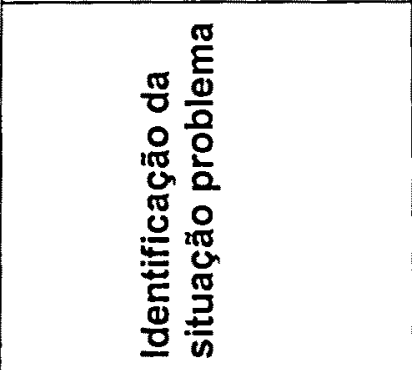 & 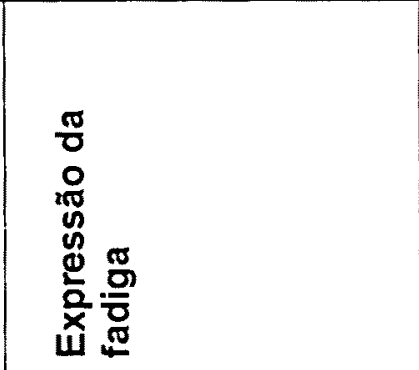 & 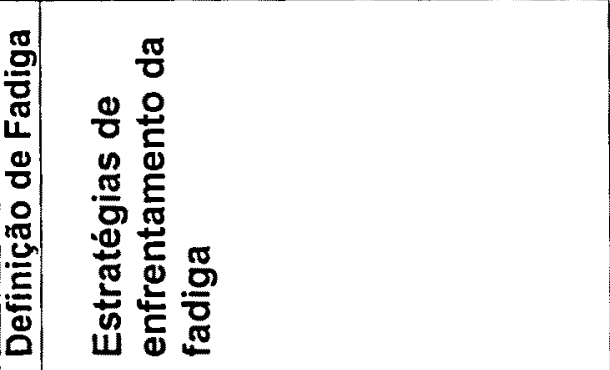 \\
\hline
\end{tabular}

